UNIVERSIDADE DE SÃO PAULO

FACULDADE DE ECONOMIA, ADMINISTRAÇAO E CONTABILIDADE DEPARTAMENTO DE ADMINISTRAÇÃO

COMPORTAMENTO DO CONSUMIDOR DE BAIXA RENDA UM ESTUDO SOBRE O PROCESSO DE COMPRA DE PRESERVATIVOS

Eduardo Neder Issa Junior

Orientadora: Profa. Dra. Ana Akemi Ikeda 
Prof. Dr. Adolpho José Melfi

Reitor da Universidade de São Paulo

Profa. Dra. Maria Tereza Leme Fleury

Diretora da Faculdade de Economia, Administração e Contabilidade

Prof. Dr. Eduardo Pinheiro Gondim de Vasconcellos

Chefe do Departamento de Administração 


\section{COMPORTAMENTO DO CONSUMIDOR DE BAIXA RENDA UM ESTUDO SOBRE O PROCESSO DE COMPRA DE PRESERVATIVOS}

Dissertação apresentada ao Departamento de Administração da Faculdade de Economia, Administração e Contabilidade da Universidade de São Paulo para obtenção do título de Mestre em Administração.

Orientadora: Profa. Dra. Ana Akemi Ikeda 


\section{FICHA CATALOGRÁFICA}

Issa Junior, Eduardo Neder

Comportamento do consumidor de baixa renda: um estudo sobre o

processo de compra de preservativos / Eduardo Neder Issa Junior. -- São

Paulo, 2004.

$198 \mathrm{p}$.

Dissertação (Mestrado) - Universidade de São Paulo, 2004

Bibliografia.

1. Comportamento do consumidor 2. Classe baixa 3. Dispositivos anticoncepcionais I. Faculdade de Economia, Administração e Contabilidade da USP II. Título.

CDD -658.8342 
A Deus.

Ao meu pai (in memorian), que certamente continuou me inspirando; à minha mãe e à minha irmã.

Aos meus filhos. 


\section{AGRADECIMENTOS}

Ao Departamento de Administração da Faculdade de Economia, Administração e Contabilidade da Universidade de São Paulo (FEA/USP), por ter me acolhido no curso de Pós-Graduação, ajudando-me em mais um passo para meu crescimento.

À minha orientadora, Prof ${ }^{\mathrm{a}}$ Dra $^{\mathrm{a}}$. Ana Akemi Ikeda, em especial, pelo acolhimento, conselhos que me fizeram chegar a este tema, atenção permanente, direcionamento valioso e preciso, além de constante incentivo.

Ao Prof. Dr. Marcos Cortez Campomar e Prof. Dr. Edson Crescitelli, pelas sugestões sempre pertinentes, contribuindo para a consistência do trabalho.

Aos funcionários do Departamento de Administração, especialmente aos da Biblioteca, Secretaria e Coordenação.

Aos colegas do curso de Pós-Graduação, pela receptividade, muitas vezes trazendo inspirações valiosas para a transposição das barreiras surgidas.

Aos meus alunos, Carlos Eduardo Neves, Francisco Alves de Lima Filho e Wagner Augusto Aguiar Quina, pela preciosa ajuda na coleta de dados.

Ao Ba Assumpção, da Popular Comunicação, e ao Renato Meirelles, da DataPopular, pela gentileza e interesse em fornecer informações.

Aos amigos do Departamento de Marketing da Johnson \& Johnson, em especial a Rita Delalibera, André Mendes, Gian Taralli e Karen Ehrlich, pelas informações fornecidas.

À minha mãe, Iracema, e à minha irmã, Rose, pelo acolhimento, apoio estrutural e emocional nos momentos mais difíceis, sem os quais este trabalho não teria sido concluído.

Aos meus filhos, Luiza e Pedro, por existirem e encherem meu mundo de alegria.

À Taís, por ter surgido em minha vida e, com seu companheirismo, paciência, compreensão e apoio, ter tornado esta jornada mais venturosa.

À Renata, pela paciência e compreensão com que cedeu seu espaço físico, onde muitas das linhas deste trabalho foram escritas.

À Dona Rute, que acompanhou de perto o desenrolar do trabalho e sempre me incentivou, mas que, infelizmente, acabou não vendo o estudo concluído. 
À Lígia, pela mensagem de perseverança e serenidade.

Ao Rubens, pelas boas idéias e suporte.

Ao Alexandre Ono, pelas ilustrações.

À Marlene Souza, pela gentil colaboração.

A todos aqueles que, direta ou indiretamente, contribuíram para a execução deste estudo. 


\section{SUMÁRIO}

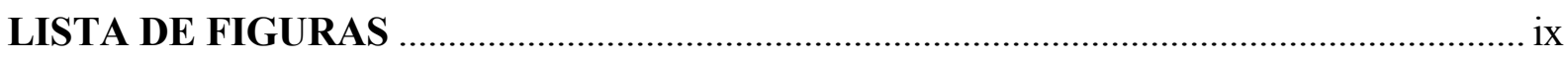

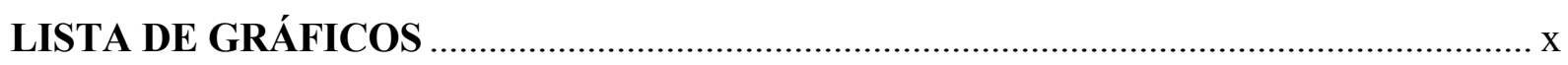

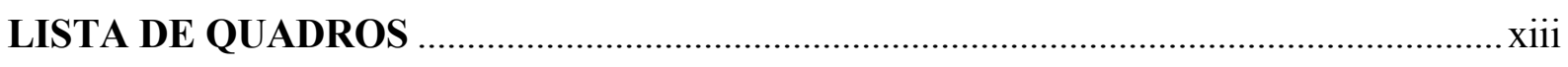

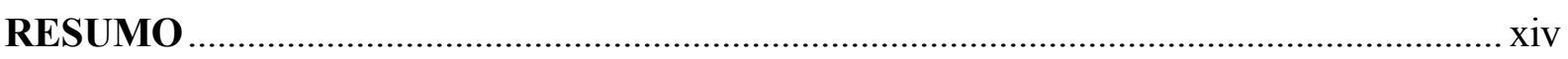

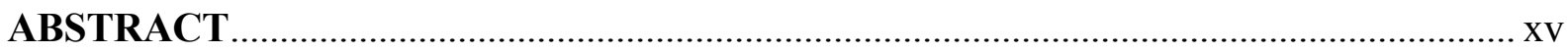

\section{PARTE I - APRESENTAÇÃO DO ESTUDO}

1 Introdução.

1.1 Aspectos gerais e importância do tema …............................................................... 1

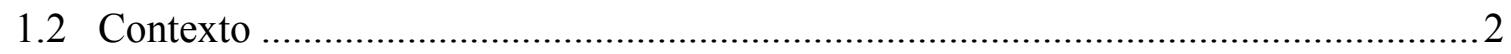

1.2.1 A situação da Aids no mundo e no Brasil .......................................................2

1.2.2 Taxa de fecundidade entre mulheres de baixa renda ....................................... 9

1.3 Critérios de classificação e conceituação da população de baixa renda................... 13

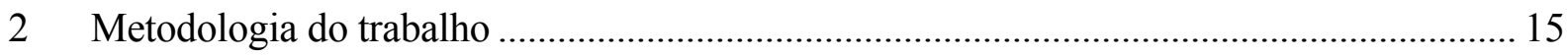

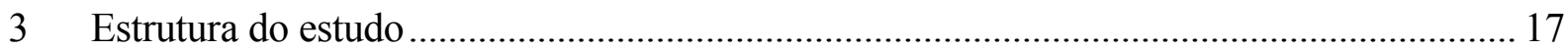

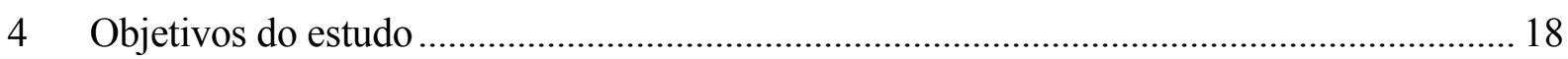

\section{PARTE II - REFERENCIAL TEÓRICO}

5 Aspectos da teoria do comportamento do consumidor .................................................... 19

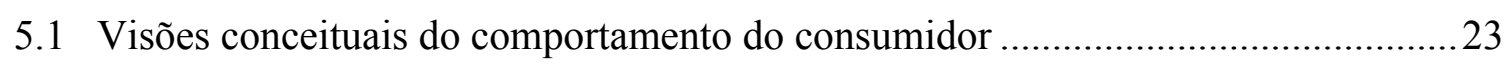

5.2 Variáveis que influenciam a tomada de decisão de compra .....................................24

5.3 O processo de tomada de decisão ...................................................................... 45

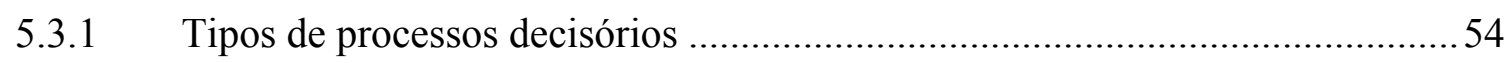

$6 \quad$ O comportamento de compra e uso de preservativo ........................................................ 57

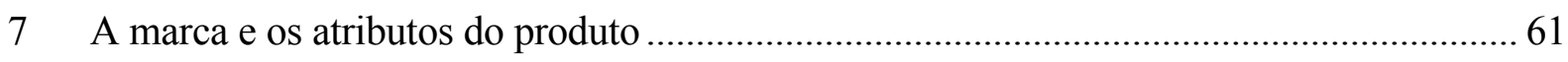

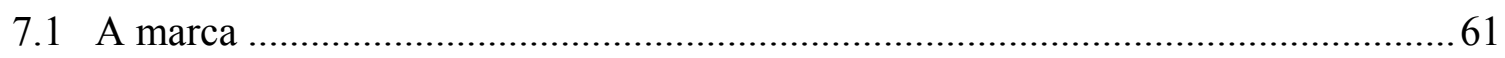

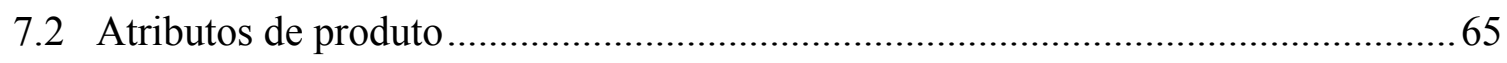

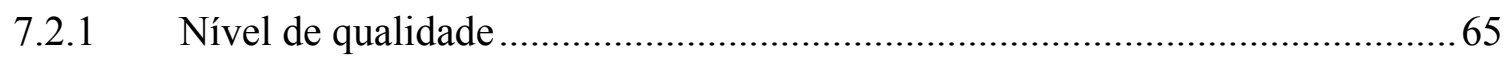

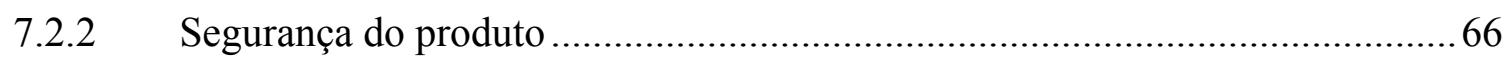

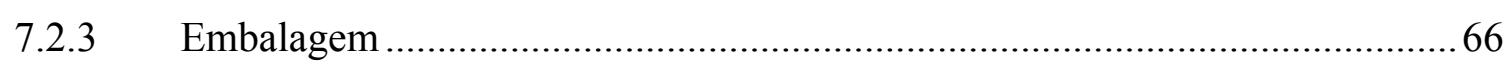

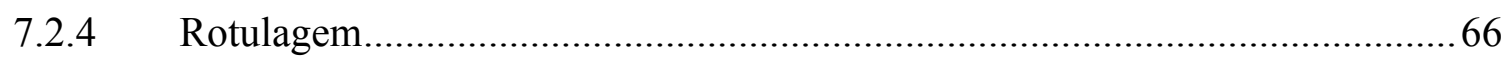

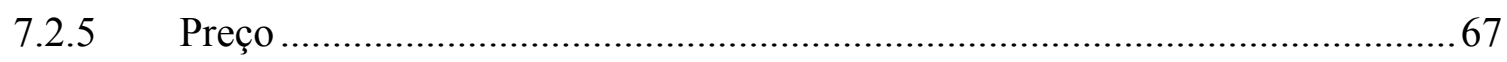

7.3 Relação entre os atributos e o comportamento do consumidor ...............................69 
PARTE III - DADOS GERAIS SOBRE POPULAÇÃO BRASILEIRA, PERFIL DAS CLASSES DE BAIXA RENDA, PRESERVATIVOS E SEUS HÁBITOS DE USO

8 A população brasileira e o perfil das classes de baixa renda ............................................... 71

8.1 Um panorama socioeconômico do Brasil..................................................................... 71

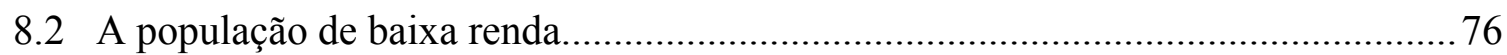

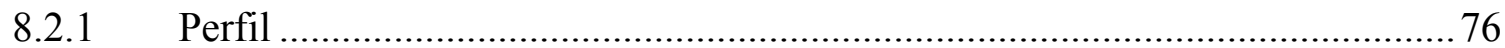

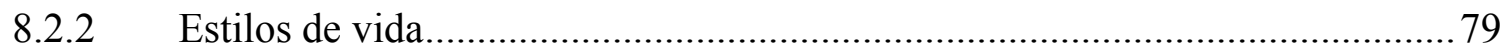

8.2.3 Comportamento de compra e estilos de consumo ........................................... 81

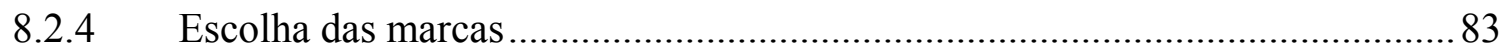

8.2.5 A comunicação nas classes populares ........................................................... 86

8.2.6 O perfil da mulher de baixa renda e seu comportamento de compra ............... 88

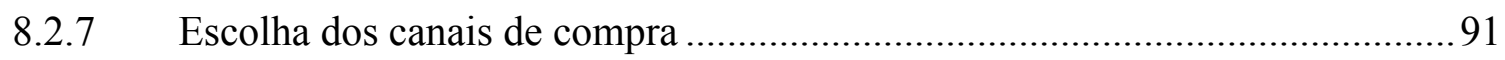

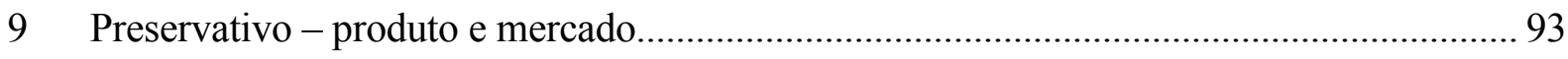

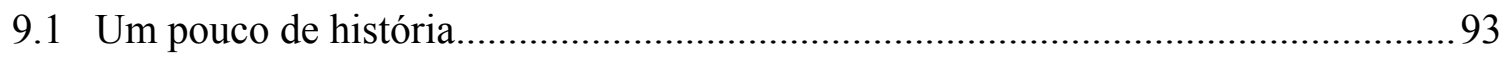

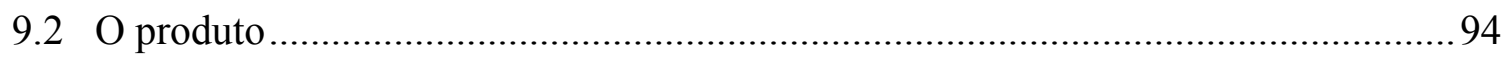

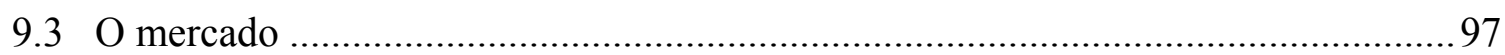

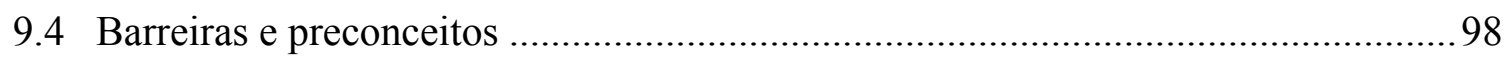

10 Comportamento do brasileiro em relação ao preservativo................................................ 100

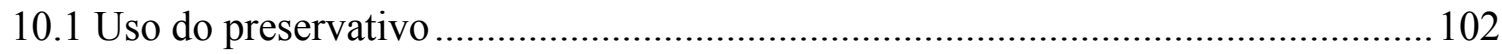

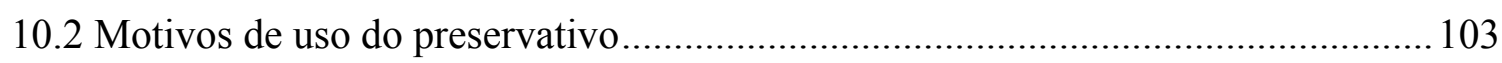

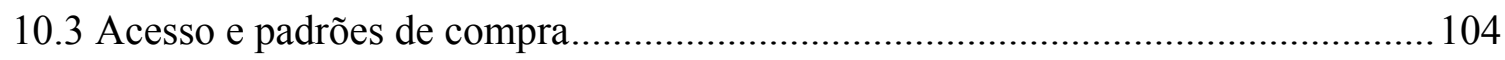

10.4 Fatores importantes na decisão de compra ......................................................... 108

11 Outra forma de prevençao - o preservativo feminino................................................... 120

\section{PARTE IV - METODOLOGIA DE PESQUISA DE CAMPO}

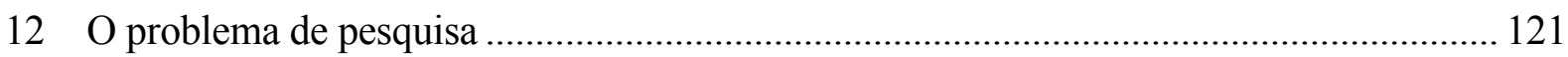

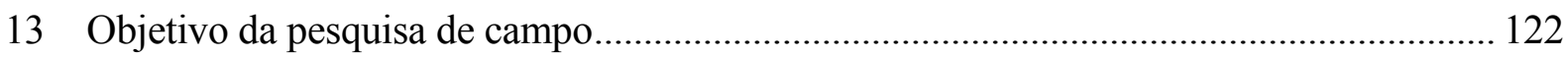

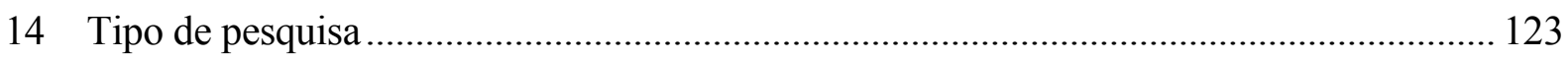

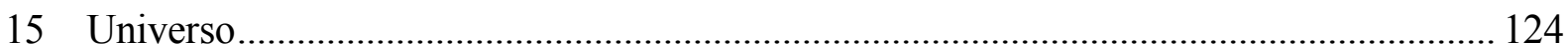

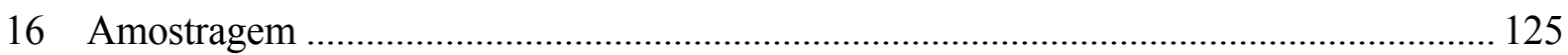

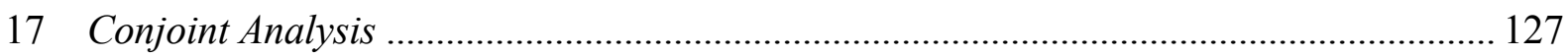

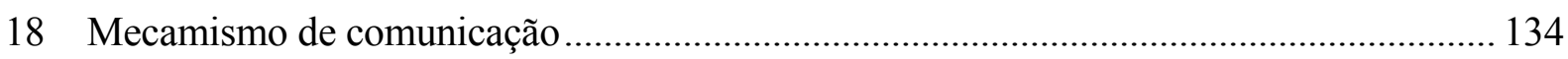

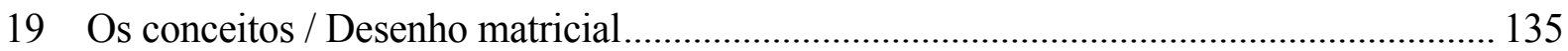

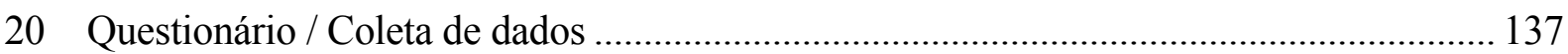




\section{PARTE V - APRESENTAÇÃO E ANÁLISE DOS RESULTADOS}

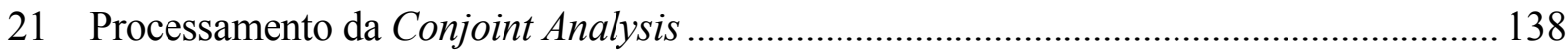

22 Apresentação dos resultados e comentários ..................................................................... 139

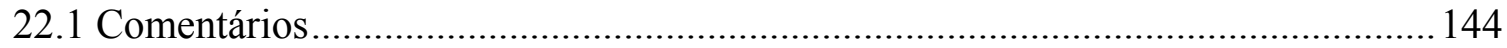

22.2 Agrupamento por faixa de idade - comentários.................................................... 152

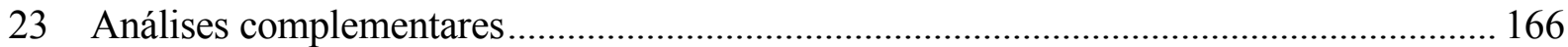

\section{PARTE VI - CONSIDERAÇÕES FINAIS}

24 Principais resultados da pesquisa de campo e associações com outras informações de

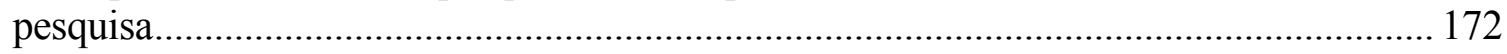

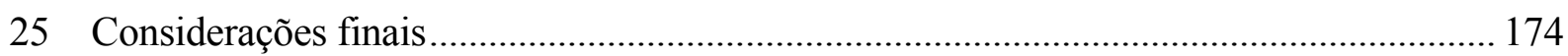

25.1 Limitações da pesquisa de campo e recomendações para próximas pesquisas.......176

BIBLIOGRAFIA

\section{APÊNDICES}

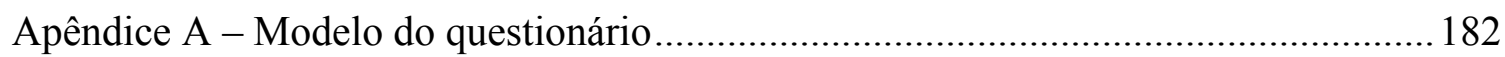

Apêndice B - Desenhos esquemáticos utilizados na coleta de dados .................................... 184

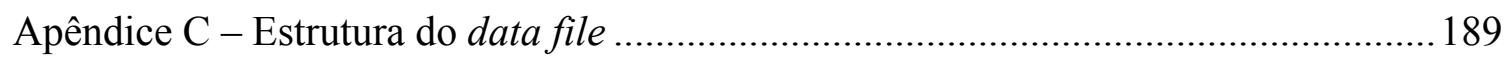

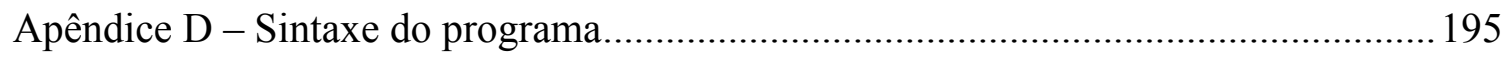

ANEXO

Anexo A - Detalhes do Critério de Classificação Econômica Brasil 196 


\section{LISTA DE FIGURAS}

Figura 1 - Questões envolvidas nas fases do processo de consumo ......................................24

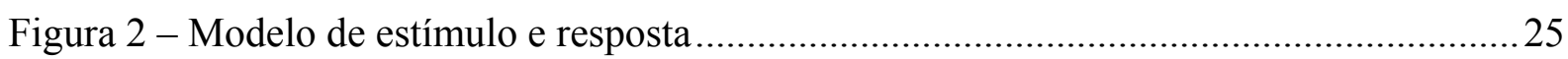

Figura 3 - Um modelo de organização do comportamento do consumidor............................28

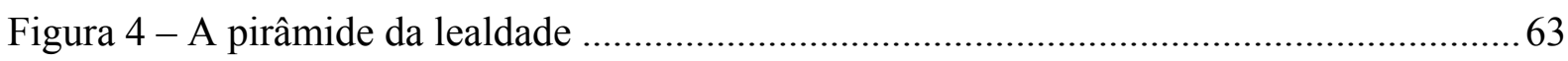

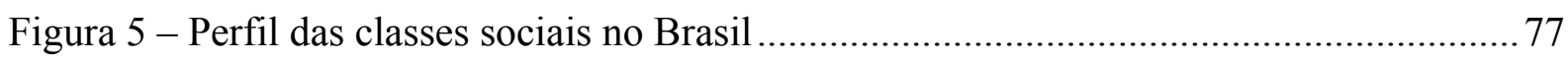

Figura 6 - Taxa anual de crescimento composto ........................................................... 77

Figura 7 - Atributos avaliados pela classe $\mathrm{C}$ na escolha da marca ....................................... 85

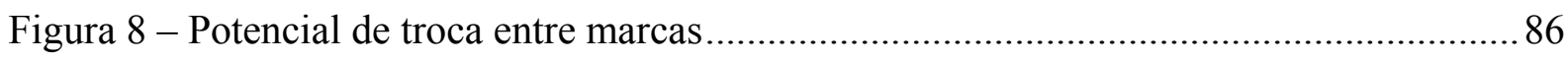

Figura 9 - Consumo de preservativos no país ................................................................... 97

Figura 10 - Distribuição das pessoas sexualmente ativas nos últimos 6 meses, de 14 anos ou mais, que compram ou compraram preservativos e receberam ou pegaram gratuitamente na rede pública (\%) - Brasil, 2003 ............................................ 105

Figura 11 - Saída numérica do programa por classe (classe C) ......................................... 140

Figura 12 - Saída numérica do programa por classe (classe D) .......................................... 141

Figura 13 - Saída numérica do programa por classe (classe E) ......................................... 142

Figura 14 - Saída numérica do programa - sumário geral (média) ..................................... 143

Figura 15 - Saída numérica do programa - sumário geral (média) ....................................... 153

Figura 16 - Saída numérica do programa por faixa de idade (faixa 1, de 18 a 27 anos) ....... 157

Figura 17 - Saída numérica do programa por faixa de idade (faixa 2, de 28 a 34 anos) ....... 158

Figura 18 - Saída numérica do programa por faixa de idade (faixa 3, de 35 a 53 anos) ....... 159 


\section{LISTA DE GRÁFICOS}

Gráfico 1 - Distribuição dos Casos de Aids no Brasil, por sexo, de 1980 a 2003 .................... 4

Gráfico 2 - Distribuição etária dos casos de Aids no Brasil, no sexo masculino, de 1980 a

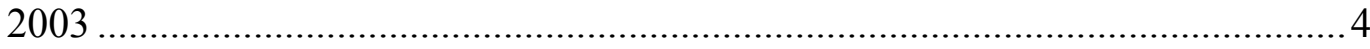

Gráfico 3 - Distribuição etária dos casos de Aids no Brasil, no sexo feminino, de 1980 a 2003

Gráfico 4 - Distribuição regional dos casos de Aids no Brasil, de 1980 a 2003 .......................5

Gráfico 5 - Taxas de incidência da Aids por região, no ano de 2002 .......................................5

Gráfico 6 - Taxa de mortalidade (por100.000 habitantes) …................................................ 7

Gráfico 7 - Taxas de fecundidade total, por classes de rendimento nominal mensal familiar per capita, em salários mínimos, no ano de 2000 .................................................9

Gráfico 8 - Crescimento da população (em milhões de pessoas) ........................................... 71

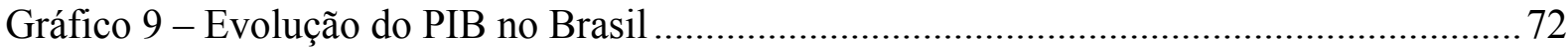

Gráfico 10 - Evolução do PIB per capita no Brasil (emR\$) ................................................. 72

Gráfico 11 - Evolução da concentração de renda no Brasil.................................................... 73

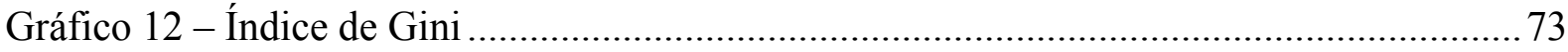

Gráfico 13 - Evolução da expectativa de vida no Brasil....................................................... 74

Gráfico 14 - Evolução da mortalidade infantil no Brasil ........................................................ 74

Gráfico 15 - Percentual da população brasileira de 14 anos e mais, sexualmente ativa nos últimos 6 meses, por região, sexo e faixa etária ....

Gráfico 16 - Distribuição da população sexualmente ativa nos últimos 6 meses, de 14 anos e mais, segundo o grau de instrução e classe econômica (\%)

Gráfico 17 - Proporção de pessoas sexualmente ativas que compra ou já comprou preservativos, segundo região de residência, sexo, cor/raça e faixa de idade .. 107

Gráfico 18 - Proporção de pessoas sexualmente ativas que compra ou já comprou preservativos, segundo escolaridade, classe econômica, número médio de relações por mês

Gráfico 19 - Distribuição do que as pessoas sexualmente ativas consideram mais importante na hora de comprar preservativos

Gráfico 20 - Distribuição do que as pessoas sexualmente ativas consideram mais importante na hora de comprar preservativos, segundo a região

Gráfico 21 - Distribuição do que as pessoas sexualmente ativas consideram mais importante na hora de comprar preservativos, segundo o sexo

Gráfico 22 - Distribuição do que as pessoas sexualmente ativas consideram mais importante na hora de comprar preservativos, segundo a cor....

Gráfico 23 - Distribuição do que as pessoas sexualmente ativas consideram mais importante na hora de comprar preservativos, segundo a cor. 
Gráfico 24 - Distribuição do que as pessoas sexualmente ativas consideram mais importante na hora de comprar preservativos, segundo a classe econômica.

Gráfico 25 - Distribuição do que as pessoas sexualmente ativas consideram mais importante na hora de comprar preservativos, segundo o grau de instrução

Gráfico 26 - Distribuição do que as pessoas sexualmente ativas consideram mais importante na hora de comprar preservativos, segundo o indicador de risco

Gráfico 27 - Distribuição do que as pessoas sexualmente ativas consideram mais importante na hora de comprar preservativos, segundo o número médio de relações sexuais por mês

Gráfico 28 - Distribuição das pessoas sexualmente ativas nos últimos 6 meses, de 14 anos e mais, segundo sua opinião sobre se usar o preservativo regularmente faria alguma diferença no orçamento mensal, segundo a região de residência ........ 116

Gráfico 29 - Distribuição das pessoas sexualmente ativas nos últimos 6 meses, de 14 anos e mais, de acordo com sua opinião sobre se usar o preservativo regularmente faria alguma diferença no orçamento mensal, segundo o sexo e a cor/raça ....

Gráfico 30 - Distribuição das pessoas sexualmente ativas nos últimos 6 meses, de 14 anos e mais, de acordo com sua opinião sobre se usar o preservativo regularmente faria alguma diferença no orçamento mensal, segundo a faixa de idade.

Gráfico 31 - Distribuição das pessoas sexualmente ativas nos últimos 6 meses, de 14 anos e mais, de acordo com sua opinião sobre se usar o preservativo regularmente faria alguma diferença no orçamento mensal, segundo a classe econômica e o grau de instrução

Gráfico 32 - Distribuição das pessoas sexualmente ativas nos últimos 6 meses, de 14 anos e mais, de acordo com sua opinião sobre se usar o preservativo regularmente faria alguma diferença no orçamento mensal, segundo o indicador de risco e o número de relações por mês .

Gráfico 33 - Resumo geral da importância média dos atributos ou fatores. 144

Gráfico 34 - Importância média dos atributos por classe econômicaErro! Indicador não definido.

Gráfico 35 - Utilidades dos níveis do atributo marca, pela avaliação média......................... 146

Gráfico 36 - Utilidades dos níveis do atributo marca, por classe ...................................... 146

Gráfico 37 - Utilidades dos níveis do atributo preço, pela avaliação média.......................... 147

Gráfico 38 - Utilidades dos níveis do atributo preço, por classe .......................................... 148

Gráfico 39 - Utilidades dos níveis do atributo formato, pela avaliação média...................... 149

Gráfico 40 - Utilidades dos níveis do atributo formato, por classe .................................... 149

Gráfico 41 - Utilidades dos níveis do atributo espessura, pela avaliação média ................... 150

Gráfico 42 - Utilidades dos níveis do atributo textura, pela avaliação média ....................... 151

Gráfico 43 - Utilidades dos níveis do atributo espessura, por classe .................................... 151

Gráfico 44 - Resumo geral da importância média dos atributos ou fatores.......................... 154

Gráfico 45 - Utilidades dos níveis do atributo marca, pela avaliação média.......................... 154

Gráfico 46 - Utilidades dos níveis do atributo preço, pela avaliação média........................... 155 
Gráfico 47 - Utilidades dos níveis do atributo formato, pela avaliação média.

Gráfico 48 - Utilidades dos níveis do atributo espessura, pela avaliação média 156

Gráfico 49 - Utilidades dos níveis do atributo textura, pela avaliação média . 156

Gráfico 50 - Importância média dos atributos por faixa de idade. 160

Gráfico 51 - Utilidades dos níveis do atributo marca, por faixa de idade 161

Gráfico 52 - Utilidades dos níveis do atributo preço, por faixa de idade 162

Gráfico 53 - Utilidades dos níveis do atributo formato, por faixa de idade. 163

Gráfico 54 - Utilidades dos níveis do atributo espessura, por faixa de idade. 164

Gráfico 55 - Importância média dos atributos por faixa de idade. 165

Gráfico 56 - Distribuição da freqüência de compra de preservativos. 169

Gráfico 57 - Distribuição de freqüências da variável unidades por compra 170 


\section{LISTA DE QUADROS}

Quadro 1 - Casos de Aids: categoria de exposição, no Brasil, no período de 1980 a 2003 ......6

Quadro 2 - Casos de Aids em indivíduos do sexo masculino com 19 anos de idade ou mais, segundo anos de estudo, no Brasil, no período de 1980 a 2003.

Quadro 3 - Número de óbitos por Aids segundo o sexo e razão entre o número de óbitos do sexo masculino e do feminino, no Brasil, no período de 1983 a 2002 ................... 8

Quadro 4 - Taxas de fecundidade total, por classes de rendimento nominal mensal familiar per capita, em salários mínimos, segundo as grandes regiões $-2000 \ldots \ldots \ldots \ldots \ldots \ldots . . . .10$

Quadro 5 - Nove estratégias de preço-qualidade ................................................................. 67

Quadro 6 - Distribuição das pessoas sexualmente ativas nos últimos 6 meses de 14 anos ou mais que compram ou já compraram preservativos, segundo região de residência, faixa de idade, sexo, cor/raça, classe econômica, grau de instrução, indicador de risco e número médio de relações por mês - Brasil, 2003 ................................ 106

Quadro 7 - Os atributos e seus níveis, usados na pesquisa ............................................... 135

Quadro 8 - Desenho fatorial fracionado obtido do SPSS, mostrando os conceitos resultantes 136

Quadro 9 - Conhecimento dos métodos contraceptivos (respostas múltiplas) ..................... 166

Quadro 10 - Conhecimento dos métodos contraceptivos (respostas múltiplas dos

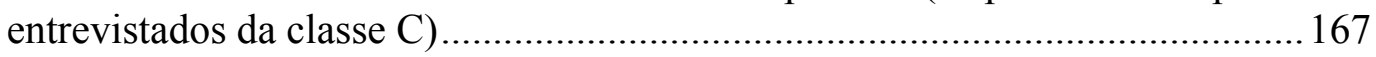

Quadro 11 - Conhecimento dos métodos contraceptivos (respostas múltiplas dos

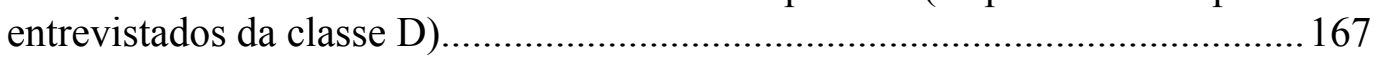

Quadro 12 - Conhecimento dos métodos contraceptivos (respostas múltiplas dos

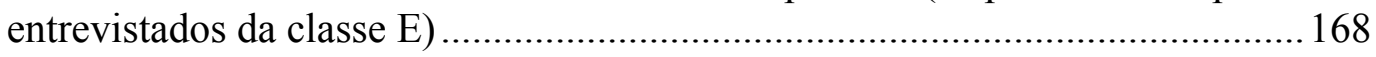

Quadro 13 - Distribuição da freqüência de compra de preservativos................................... 168

Quadro 14 - Resultados estatísticos para a variável unidades por compra ........................... 169

Quadro 15 - Distribuição de freqüências da variável unidades por compra ......................... 170 


\section{RESUMO}

Este estudo versa sobre o comportamento de um grupo específico de consumidores brasileiros, classificados como de baixa renda, e busca avaliar como se dá o processo de tomada de decisão na compra de preservativos.

Basicamente dois fatores justificam a importância do tema: o primeiro é o fato de que um dos segmentos que mais têm sido afetados pelo aumento da incidência da Aids é a população de baixa renda; o segundo, é a constatação de que crescem as taxas de fecundidade entre mulheres dessa mesma classe. As conseqüências socioeconômicas desses fatos podem ser graves. O uso de métodos contraceptivos e de prevenção contra a doença parece ser, portanto, o caminho para se amenizar o problema. O preservativo tem papel de destaque nessa luta.

Tendo isso em vista, o trabalho procura lançar luz à compreensão do perfil das classes populares, seus estilos de vida e de compra, dando foco ao produto preservativo. A revisão da literatura trata da teoria do comportamento do consumidor, associando-a a estudos sobre hábitos de uso do preservativo e a considerações sobre atributos do mesmo.

A pesquisa de campo procura identificar quais atributos do preservativo são considerados mais importantes pelos consumidores de baixa renda e qual o peso relativo dessa importância. Para tanto, faz uso de um estudo exploratório-descritivo, apoiado no método de análise da Conjoint Analysis, próprio para avaliação relativa entre atributos. Os principais resultados apresentados mostram que esses consumidores consideram fortemente a importância da marca e do preço, mas não desprezam fatores como formato e textura.

Para concluir, as considerações finais destacam que os resultados apresentados sugerem oportunidades de ações de marketing que chamem a atenção dos atributos identificados como de maior importância relativa e permitam o maior acesso do indivíduo de baixa renda ao preservativo. 


\begin{abstract}
This thesis is about the behavior of a specific group of brazilian consumers who are classified as low income people. It aims to evaluate how they choose and buy condoms.

There are mainly two factors that make this research important: the first one is related to the fact that the number of low income people with Aids is increasing; the second one is related to the growing birth rate in the low income group. The social and economical consequences of these factors are really serious. Using condom can be one of the ways to prevent Aids and pregnancy. Because of this, condom has an important role in this situation.

This research intends to understand the profile of the low income groups, their way of living and buying, especially condoms. The theoretical review is based on the consumer behavior, relating it to the searches about the condom using habits and their attributes.

The marketing research aims to identify which condom attributes are considered more important by the low income consumers and how such attributes are important or not to these consumers. The main results show that the consumers really consider the condom brand and price, but they also consider the format and texture.
\end{abstract}

Finally, we conclude that there are marketing opportunities related to the condom attributes identified as the most important ones to the low income consumers. 


\section{PARTE I}

\section{APRESENTAÇÃO DO ESTUDO}

\section{INTRODUÇÃO}

\subsection{ASPECTOS GERAIS E IMPORTÂNCIA DO TEMA}

A grande incidência de casos de Aids no país é motivo de preocupação de políticas governamentais, exigindo novas posturas de ordem educacional, cultural e de saúde. Apesar de o Brasil ter implementado políticas de tratamento gratuito da doença à população e, devido a isso, ter conseguido uma trégua no crescimento da doença, o quadro revela-se extremamente preocupante, pois o número de óbitos ainda é alto e qualquer descuido pode significar sério retrocesso. Os impactos no cenário socioeconômico do país são visíveis, dentre eles o aumento nos níveis de investimento na saúde direcionados à doença, além das mudanças de padrões comportamentais mediante a doença percebidas dentro e fora dos grupos de risco.

Esse quadro fica ainda mais preocupante quando analisado sob o prisma da estratificação social. Dois fatores vêm corroborar o aumento da complexidade da situação: o primeiro, ainda relacionado à doença, é a constatação de que um dos grupos em que a epidemia evolui mais vorazmente é o da população de baixa renda; o segundo, de caráter demográfico, é a confirmação de que as mulheres das camadas econômicas mais inferiores apresentam uma taxa de fecundidade em ascensão, retro-alimentando o círculo vicioso da pobreza do país, e acarretando conseqüência direta para a formulação das políticas sociais no Brasil.

O uso do preservativo nas classes populares pode ser uma ferramenta eficaz para a inibição do aumento da incidência de Aids e para o controle da natalidade e, desta forma, o estudo dos fatores que influenciam o consumidor dessa faixa da população a comprar pode representar significativa contribuição para amenizar o quadro anteriormente exposto.

A indústria de preservativos deve ter um papel determinante nesse cenário. Conhecer 
melhor o consumidor de baixa renda e seus hábitos de uso e de compra pode influenciar decisivamente na incorporação de características ao produto que venham ao encontro das necessidades daquele consumidor. Conferir atributos adequados ao produto é, sem dúvida, um meio essencial para diminuir a distância entre o produto e seu comprador.

O interesse dessa dissertação está em entender melhor a avaliação dos atributos de preservativos valorizados pelo consumidor de baixa renda e, assim, lançar luz a novos caminhos que tornem o produto mais adequado, acessível e de uso freqüente para tal consumidor.

\subsection{CONTEXTO}

\subsubsection{A SITUAÇÃO DA AIDS NO MUNDO E NO BRASIL}

Apesar dos esforços políticos, do progresso científico e do aumento de verbas para ampliação do acesso ao tratamento da Aids, a epidemia é resistente, devastadora e continua atemorizando o mundo.

No mundo todo, o volume de pessoas infectadas pelo HIV (vírus da imunodeficiência humana) continua crescendo. De 2001 a 2003, a estimativa passou de 35 para 38 milhões, segundo o Programa das Nações Unidas sobre HIV/AIDS - UNAIDS, em notícia divulgada pelo Programa Nacional de DST e AIDS (2004). A proporção de mulheres com a doença tem crescido sistematicamente, representando cerca de $50 \%$ dos portadores do vírus em 2002 . A epidemia também persegue os jovens de forma desproporcional; os da faixa entre 15 e 24 anos são responsáveis pela metade dos novos casos de Aids no mundo.

Só em 2003, o total dos que se infectaram com o vírus chegou próximo à marca de 5 milhões. Responsável por cerca de $60 \%$ da população mundial, a Ásia hoje registra um dos maiores crescimentos da epidemia no mundo, totalizando, no final de 2003, o volume estimado de 7,4 milhões de pessoas infectadas, contra 6,6 milhões do final de 2002. China, Indonésia e Vietnam, representando conjuntamente $50 \%$ da população do continente, são os países apontados como os que mais contribuíram para esse incremento. Na Índia, são cerca de 5,1 milhões de portadores da doença. Na África Subsaariana, estima-se que, no final de 2003, o número de pessoas portadoras do vírus era de 25 milhões, comparado com 
aproximadamente 24 milhões do final de 2001. Dos 3 milhões de óbitos devidos à Aids em 2003, 2,2 milhões (75\%) ocorreram nessa região.

Na América Latina, a população de infectados chega a aproximadamente 1,6 milhão de pessoas, concentrando-se, principalmente, nos chamados grupos de risco, como os viciados em drogas e os homossexuais.

Segundo o referido organismo internacional, a ampla disponibilidade de medicamentos para a doença em países de alta-renda tem estimulado o aumento do comportamento de alto risco, levando a novos casos de infecção. Na América do Norte, por exemplo, havia 950.000 pessoas contaminadas com o HIV em 2001, contra 1 milhão de pessoas em 2003. Na Europa, o crescimento foi de 540.000 pessoas em 2001 para 580.000 em 2003.

Apesar dos investimentos mundiais no combate à doença terem se expandido de US\$ 300 milhões em 1996 para quase US\$ 5 bilhões em 2003, a UNAIDS (2004) aponta que, para atender aos países em desenvolvimento, serão necessários US\$ 12 bilhões em 2005 e US\$ 20 bilhões em 2006.

No Brasil, os dados são alarmantes da mesma forma, apesar da notável melhora dos indicadores de desempenho no combate à doença no país. O número de casos de Aids registrados pelo Ministério da Saúde (BRASIL, 2003) desde o início da década de 1980 até dezembro de 2003, alcançou a marca de 310.310, representando um aumento de $20,4 \%$ em relação aos números consolidados de 2002. São 220.783 ocorrências com homens (aproximadamente $71 \%$ do total) e 89.527 com mulheres, como pode ser visto no gráfico $1{ }^{1}$ A faixa etária mais acometida é a de 25 a 49 anos para o sexo masculino, com $79 \%$ das ocorrências e a de 20 a 49 anos para o sexo feminino, com 83,4\%, conforme está ilustrado nos gráficos 2 e 3 . Vale observar que, ao longo do tempo, ocorre um aumento percentual progressivo nas faixas etárias mais avançadas, tanto da população mas-culina como da feminina. As regiões Sudeste e Sul concentram 84,8\% dos casos (gráfico 4).

\footnotetext{
${ }^{1}$ Os gráficos 1 a 5 foram construídos pelo autor deste estudo, a partir de dados e informações publicados no Boletim Epidemiológico Aids, do PROGRAMA NACIONAL DE DST E AIDS (MS/SPS/CN-DST/Aids, Brasil). Disponível em: <http://www.aids.org.br/final/biblioteca/boletim_dezembro_2003>. Acesso: 04 jul. 2004.
} 
De 1988 a 2003, observou-se uma desaceleração da epidemia, evoluindo os novos casos anuais de 30 mil para 22 mil. Tomado o ano de 2002 como referência para fins de análise de novas incidências, uma vez que o Ministério da Saúde considera os dados de 2003 ainda preliminares, os casos diagnosticados representaram nesse ano uma taxa de incidência de 12,8 / 100.000 habitantes, inferior 13,5\% em relação à taxa de 2001 (de 14,8 / 100.000 habitantes). Apesar de as taxas de incidência terem se mantido estáveis nos últimos três anos, isso não aconteceu de forma homogênea em todas as regiões do país, sustentando a região Sul o maior índice por 100.000 habitantes $(20,7)$ contra as regiões Sudeste $(17,1)$, Centro-Oeste $(7,9)$, Nordeste $(5,3)$ e Norte $(5,1)$ (gráfico5).

Gráfico 1 - Distribuição dos Casos de Aids no Brasil, por sexo, de 1980 a 2003

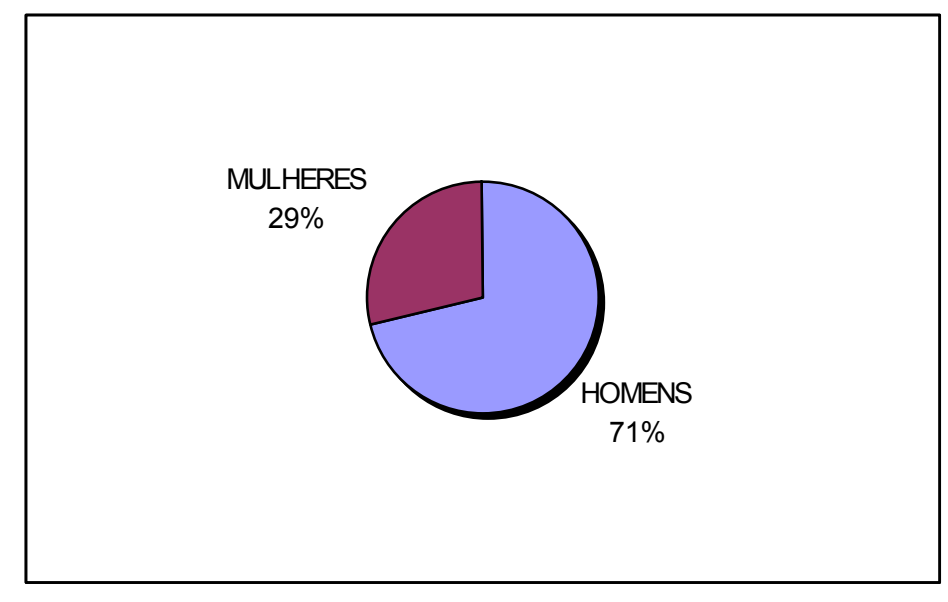

Gráfico 2 - Distribuição etária dos casos de Aids no Brasil, no sexo masculino, de 1980 a 2003

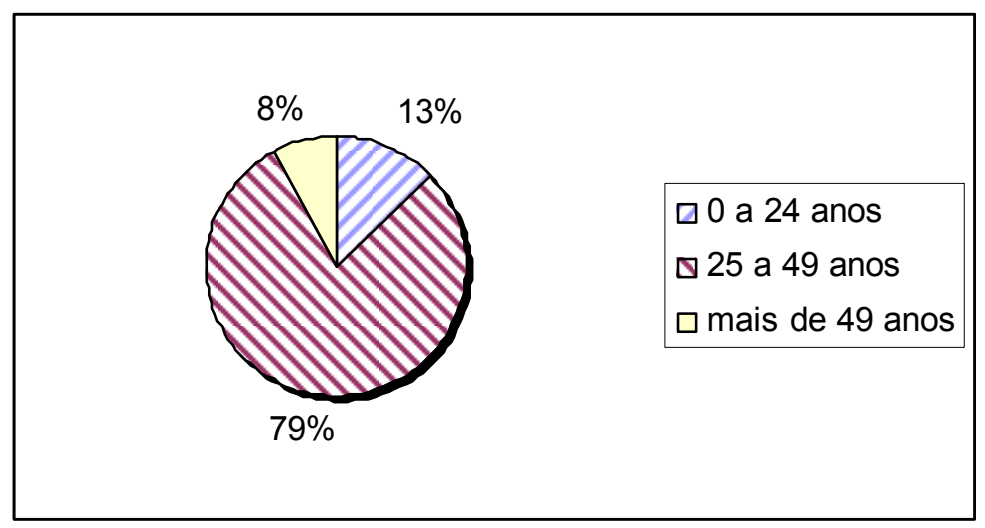


Gráfico 3 - Distribuição etária dos casos de Aids no Brasil, no sexo feminino, de 1980 a 2003

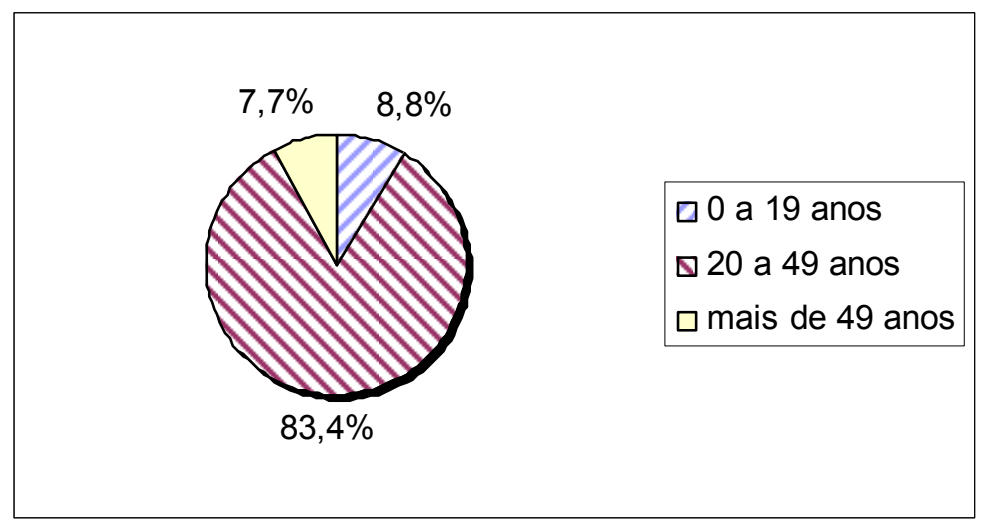

Gráfico 4 - Distribuição regional dos casos de Aids no Brasil, de 1980 a 2003

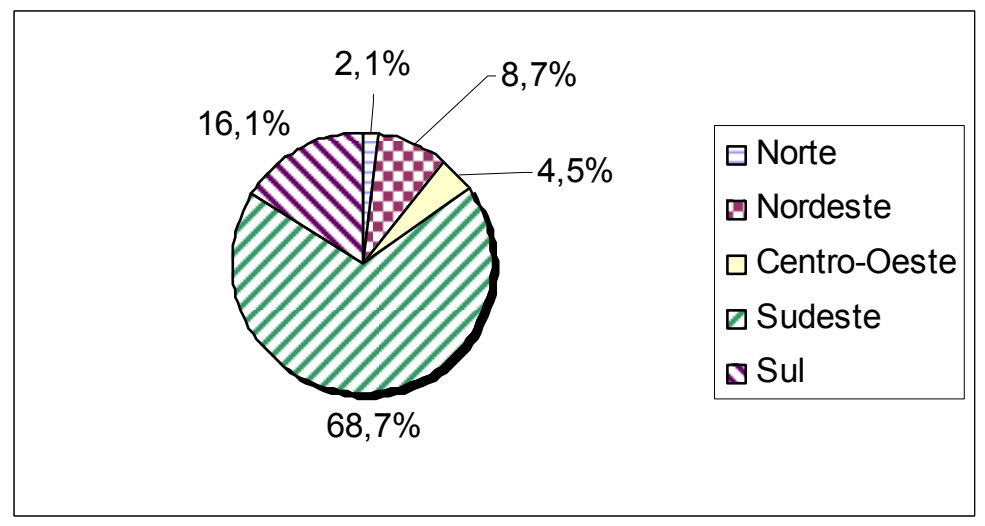

Gráfico 5 - Taxas de incidência da Aids por região, no ano de 2002

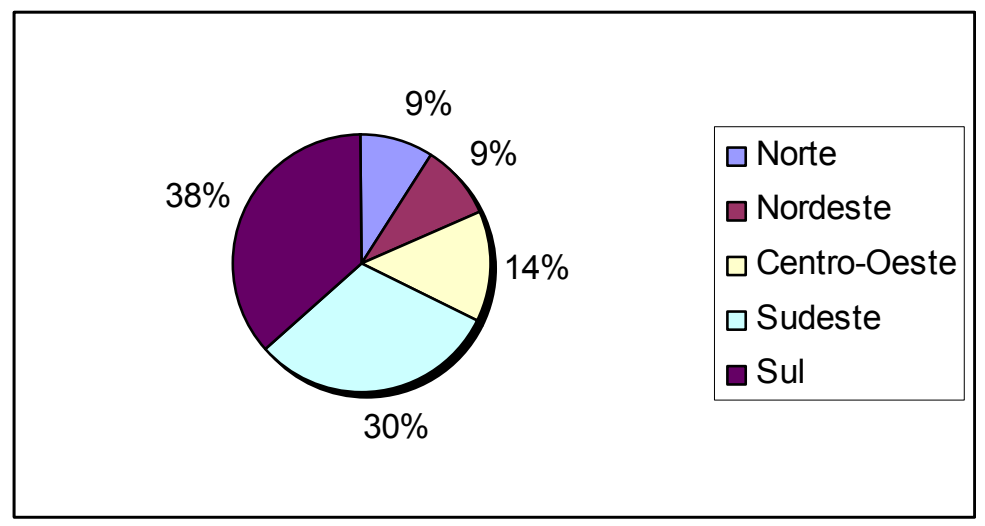

No que se refere à categoria de exposição, do total de casos diagnosticados desde 1980, $197.902(63,8 \%)$ foram provocados pela exposição sexual, 63.000 (20,3\%) pela 
sanguínea e $8.900(2,9 \%)$ pela perinatal ${ }^{2}$. Na primeira, o maior número de casos ocorreu entre heterossexuais (41,5\%), seguido dos homossexuais $(14,7 \%)$ e dos bissexuais $(7,6 \%)$. É interessante observar que, já na década de 1990, essa categoria sofreu mudanças significativas de prevalência, de homo / bissexual masculino para heterossexual de ambos os sexos, apresentando uma desconcentração e conseqüente expansão da doença para outros grupos da população. A segunda causa é liderada pelos casos de UDI - usuários de drogas injetáveis $(19 \%)$, seguida dos hemofílicos $(0,4 \%)$ e das transfusões $(0,8 \%)$. Nota-se que $13,1 \%$ das ocorrências têm causa ignorada. Essas informações estão resumidas no quadro 1.

Quadro 1 - Casos de Aids: categoria de exposição, no Brasil, no período de 1980 a 2003

\begin{tabular}{|c|c|c|}
\hline \multirow{2}{*}{ Categoria de Exposição } & \multicolumn{2}{|c|}{$1980-\mathbf{2 0 0 3}$} \\
\cline { 2 - 3 } & $\mathbf{N}^{\circ}$ de Casos & \% \\
\hline Sexual & 197.902 & 63,8 \\
\hline Homossexual & 45.510 & 14,7 \\
\hline Bissexual & 23.702 & 7,6 \\
\hline Heterossexual & 128.690 & 41,5 \\
\hline Sanguínea & 63.000 & 20,3 \\
\hline UDI & 59.086 & 19,0 \\
\hline Hemofílico & 1.297 & 0,4 \\
\hline Transfusão & 2.617 & 0,8 \\
\hline Perinatal & 8.900 & 2,9 \\
\hline Acidente de trabalho & 1 & 0,0 \\
\hline Ignorada & 40.507 & 13,1 \\
\hline TOTAL & $\mathbf{3 1 0 . 3 1 0}$ & $\mathbf{1 0 0 , 0}$ \\
\hline
\end{tabular}

Fonte: Adaptado de MS/SPS/CN-DST/Aids - Dados e pesquisas em DST e Aids (BRASIL, 2003). Disponível em: $<$ http://www.aids.gov.br/final/dados/aids.htm>. Acesso em: 04 jul.2004.

Observação importante para este trabalho é o fato de a incidência da Aids ser maior, quanto menor for o número de anos de estudo do indivíduo. No sexo masculino, a baixa escolaridade (1 a 7 anos) corresponde a 46,3\% do total dos casos, enquanto no feminino, essa proporção chega a 54,5\%, conforme pode ser visualizado no quadro 2 . A evolução, ao longo

\footnotetext{
${ }^{2}$ Exposição advinda do contato do feto, anterior e posterior ao parto, com ambiente contaminado pelo vírus da Aids, segundo o Dicionário Aurélio. Disponível em: <http://www.uol2.com.br/aurelio>. Acesso em: 11 jul.2004.
} 
do período de 1983 a 2003, mostra que diminuem as ocorrências da doença quando aumenta o grau de escolaridade, tanto no sexo masculino como no feminino, sendo esse aspecto mais intenso entre homens do que mulheres.

Quadro 2 - Casos de Aids em indivíduos do sexo masculino com 19 anos de idade ou mais, segundo anos de estudo, no Brasil, no período de 1980 a 2003

\begin{tabular}{|c|c|c|}
\hline \multirow{2}{*}{ Anos de Estudo } & \multicolumn{2}{|c|}{$1980-2003$} \\
\cline { 2 - 3 } & No de Casos & \% \\
\hline Nenhum & 6.425 & 3,0 \\
1 a 3 anos & 46.543 & 21,9 \\
4 a 7 anos & 51.870 & 24,4 \\
8 a 11 anos & 35.316 & 16,6 \\
12 anos e mais & 20.536 & 9,6 \\
Ignorado & 52.265 & 24,5 \\
\hline TOTAL & $\mathbf{2 1 2 . 9 5 5}$ & $\mathbf{1 0 0 , 0}$ \\
\hline
\end{tabular}

Fonte: Adaptado de MS/SPS/CN-DST/Aids - Dados e pesquisas em DST e Aids (BRASIL, 2003). Disponível em: <http://www.aids.gov.br/final/dados/aids.htm>. Acesso em: 04 jul.2004.

Como resultado de uma política agressiva de combate à doença a partir de 1996, quando o governo brasileiro passou a distribuir medicamentos, o número de óbitos começou a ser reduzido e vem mostrando uma tendência de estabilização nos últimos anos. Entre 1995 e 2002, a taxa de mortalidade por 100.000 habitantes registrou queda de 35\% e, desde 1999 , tem permanecido na marca de 6,3, como pode ser observado no gráfico 6 .

Gráfico 6 - Taxa de mortalidade (por100.000 habitantes)

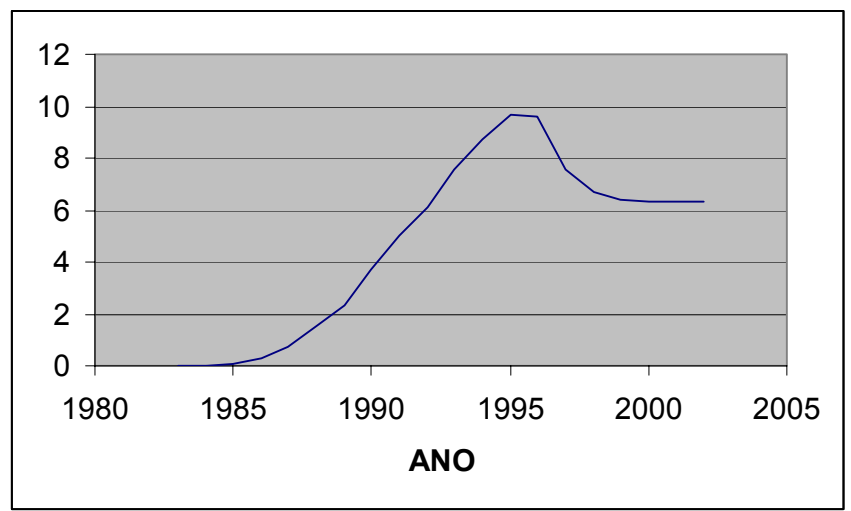

Fonte: Adaptado de MS/SPS/CN-DST/Aids - Dados e pesquisas em DST e Aids (BRASIL, 2003). Disponível em: <http://www.aids.gov.br/final/dados/aids.htm>. Acesso em: 04 jul.2004. 
Apesar desse avanço no Brasil, o quadro ainda é desalentador. O número de óbitos por Aids acumulado no período de 1983 a 2002 atinge a marca de 149.557, sendo 113.333 $(75,7 \%)$ no sexo masculino e 36.224 (24,3\%) no sexo feminino e, hoje, a taxa aproxima-se de 11 mil casos por ano, figurando como a segunda causa de óbitos entre homens jovens e a quarta causa entre mulheres, segundo o Ministério da Saúde (quadro 3).

Quadro 3 - Número de óbitos por Aids segundo o sexo e razão entre o número de óbitos do sexo masculino e do feminino, no Brasil, no período de 1983 a 2002

\begin{tabular}{|c|c|c|c|c|c|}
\hline \multirow[b]{2}{*}{ Ano } & \multicolumn{4}{|c|}{ Número de Óbitos } & \multirow{2}{*}{$\begin{array}{c}\text { Razão de Sexo } \\
\text { (M/F) }\end{array}$} \\
\hline & Masculino (M) & Feminino $(F)$ & Ignorado & Total & \\
\hline 1983 & 1 & - & - & 1 & \\
\hline 1984 & 4 & 1 & - & 5 & 4,0 \\
\hline 1985 & 149 & 6 & - & 155 & 24,8 \\
\hline 1986 & 363 & 22 & - & 385 & 16,5 \\
\hline 1987 & 878 & 85 & - & 963 & 10,3 \\
\hline 1988 & 1.800 & 256 & - & 2.056 & 7,0 \\
\hline 1989 & 2.840 & 434 & - & 3.274 & 6,5 \\
\hline 1990 & 4.632 & 750 & 1 & 5.383 & 6,2 \\
\hline 1991 & 6.135 & 1.229 & 3 & 7.367 & 5,0 \\
\hline 1992 & 7.449 & 1.564 & 7 & 9.020 & 4,8 \\
\hline 1993 & 9.239 & 2.220 & 10 & 11.469 & 4,2 \\
\hline 1994 & 10.582 & 2.790 & 19 & 13.391 & 3,8 \\
\hline 1995 & 11.599 & 3.535 & 22 & 15.156 & 3.3 \\
\hline 1996 & 11.176 & 3.828 & 13 & 15.017 & 2,9 \\
\hline 1997 & 8.749 & 3.321 & 8 & 12.072 & 2,6 \\
\hline 1998 & 7.670 & 3.093 & 4 & 10.767 & 2,5 \\
\hline 1999 & 7.487 & 3.027 & 7 & 10.521 & 2,5 \\
\hline 2000 & 7.537 & 3.187 & 3 & 10.727 & 2,4 \\
\hline 2001 & 7.512 & 3.426 & 3 & 10.941 & 2,2 \\
\hline 2002 & 7.575 & 3.470 & 2 & 11.047 & 2,2 \\
\hline TOTAL & 113.377 & 36.244 & 102 & 149.723 & 3,1 \\
\hline
\end{tabular}

Fonte: Adaptado de MS/SPS/CN-DST/Aids - Dados e pesquisas em DST e Aids (BRASIL, 2003). Disponível em: $<$ http://www.aids.gov.br/final/dados/aids.htm>. Acesso em: 04 jul.2004.

A média de novos casos da doença dos últimos três anos ainda se mostra elevada. Devido a esse fato, o governo estabeleceu metas agressivas para o Programa Nacional de 
DST-AIDS do Ministério da Saúde (2003) até 2006, último ano da gestão Luiz Inácio Lula da Silva, priorizando ações para os grupos nos quais se registrou evolução da epidemia: mulheres, jovens, usuários de drogas injetáveis, profissionais do sexo e a população de baixa renda.

Este estudo procura observar mais de perto o último grupo, a classe de baixa renda, não só pela alta incidência de casos da Aids, como também por um fator multiplicador que preocupa as autoridades da saúde: a crescente taxa de fecundidade das mulheres dessa classe, analisada com mais detalhes na seção 1.2.2.

\subsubsection{TAXA DE FECUNDIDADE ENTRE MULHERES DE BAIXA RENDA}

Segundo o IDB (Indicadores de Dados Básicos) - 2002, fecundidade é conceituada como "o número médio de filhos nascidos vivos, tidos por uma mulher ao final do seu período reprodutivo, na população residente em determinado espaço geográfico".

As estimativas do Censo Demográfico 2000, do Instituto Brasileiro de Geografia e Estatística (IBGE, 2000), mostram que a fecundidade varia consideravelmente, quando se comparam famílias com diferentes rendimentos per capita. Quanto mais alto é o rendimento, mais baixa é a fecundidade, levando à conclusão de que a melhor condição econômica da família desperta a percepção da mulher quanto ao controle dos nascimentos (gráfico 7). Esse quadro pode ser observado em todas as Grandes Regiões do país nos anos de 1991 e 2000, conforme apresentado no quadro 4.

Gráfico 7 - Taxas de fecundidade total, por classes de rendimento nominal mensal familiar per capita, em salários mínimos, no ano de 2000

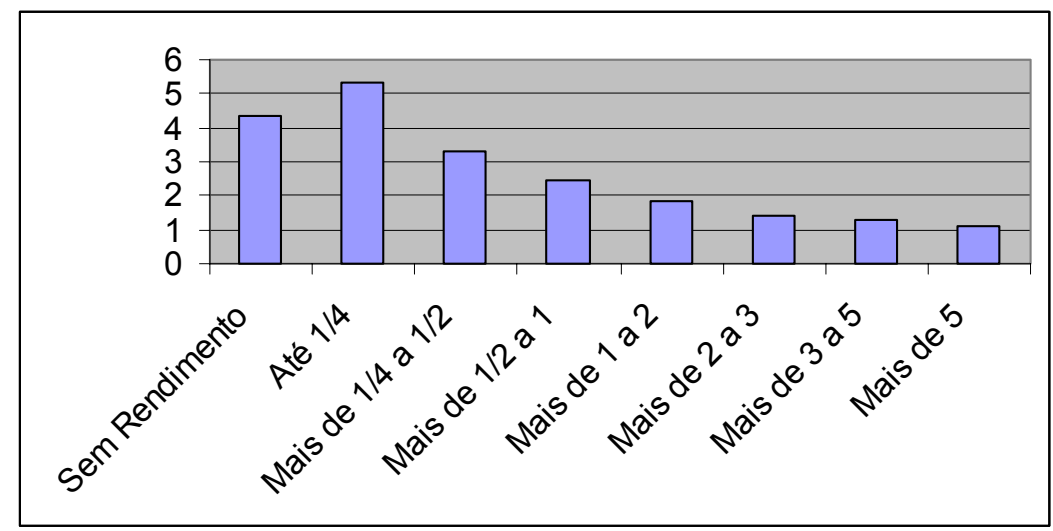

Fonte: Elaborado pelo autor a partir de informações do IBGE - Censo Demográfico 2000. Disponível em: $<$ http://www.ibge.gov.br $>$. Acesso em: 04 jul.2004. 
Quadro 4 - Taxas de fecundidade total, por classes de rendimento nominal mensal familiar per capita, em salários mínimos, segundo as grandes regiões - 2000

\begin{tabular}{|c|c|c|c|c|c|c|c|c|}
\hline Grandes Regiões & $\begin{array}{c}\text { Sem } \\
\text { Rendimento }\end{array}$ & $\begin{array}{r}\text { Ate } \\
1 / 4 \\
\end{array}$ & $\begin{array}{l}\text { TVals de } \\
1 / 4 \text { a } 1 / 2 \\
\end{array}$ & $\begin{array}{l}\text { Mais de } \\
1 / 2 \text { a } 1 \\
\end{array}$ & $\begin{array}{c}\text { Mals de } \\
1 \text { a } 2 \\
\end{array}$ & $\begin{array}{c}\text { Mais de } \\
2 \text { a } 3 \\
\end{array}$ & $\begin{array}{c}\text { Mais de } \\
3 \text { a } 5 \\
\end{array}$ & $\begin{array}{r}\text { Mals } \\
\text { de } 5 \\
\end{array}$ \\
\hline & \multicolumn{8}{|c|}{1991} \\
\hline Brasil & 5,14 & 4,99 & 3,22 & 2,41 & 1,83 & 1,5 & 1,35 & 1,08 \\
\hline Norte & 5,97 & 6,8 & 4,17 & 2,91 & 2,11 & 1,95 & 1,71 & 1,44 \\
\hline Nordeste & 5,17 & 5,19 & 2,84 & 2,05 & 1,66 & 1,63 & 1,47 & 1,32 \\
\hline Sudeste & 4,92 & 4,57 & 3,25 & 2,44 & 1,82 & 1,45 & 1,32 & 1,05 \\
\hline Sul & 4,95 & 4,53 & 3,43 & 2,54 & 1,88 & 1,51 & 1,27 & 1,2 \\
\hline \multirow[t]{2}{*}{ Centro-Oeste } & 5,35 & 4,56 & 3,46 & 2,47 & 1,93 & 1,74 & 1,59 & 1,17 \\
\hline & \multicolumn{8}{|c|}{2000} \\
\hline Brasil & 4,32 & 5,30 & 3,28 & 2,43 & 1,84 & 1,43 & 1,31 & 1,11 \\
\hline Norte & 5,34 & 6,30 & 3,69 & 2,61 & 2,01 & 1,73 & 1,50 & 1,46 \\
\hline Nordeste & 4,39 & 5,12 & 2,69 & 1,91 & 1,50 & 1,38 & 1,27 & 1,27 \\
\hline Sudeste & 4,17 & 5,26 & 3,59 & 2,60 & 1,86 & 1,39 & 1,27 & 1,05 \\
\hline Sul & 4,28 & 5,55 & 3,80 & 2,66 & 1,99 & 1,48 & 1,33 & 1,02 \\
\hline Centro-Oeste & 4,09 & 4,72 & 3,39 & 2,42 & 1,87 & 1,52 & 1,55 & 1,28 \\
\hline
\end{tabular}

Fonte: Adaptado de IBGE - Censo Demográfico 2000. Disponível em: $<$ http://www.ibge.gov.br $>$. Acesso em: 04 jul.2004.

Nota-se que, em 1991, as taxas mais altas de fecundidade eram encontradas nas famílias sem rendimentos declarados, com um grande vale entre essa faixa de renda e a faixa mais alta (mais de 5 salários mínimos). Analisando-se por região, essa diferença variou entre 3,75 filhos por mulher no Sul e 4,53 no Norte. Esta última região chama atenção por ter a mais alta fecundidade entre as famílias com renda per capita de até 1/4 do salário mínimo, 6,80 filhos por mulher.

Já em 2000, houve uma redução nas diferenças entre a menor e a maior faixa de renda, variando de 2,81 filhos por mulher no Centro-Oeste para 3,88 no Norte. Observa-se que, no Sudeste, Sul e Centro-Oeste, aumentaram as taxas de fecundidade para as famílias com até $1 / 2$ do salário mínimo per capita, destacando-se o Sul com aumento de quase 1 filho por mulher na faixa de até $1 / 4$ do salário mínimo.

O IBGE (2000) ainda observa:

Vale ressaltar que os diferenciais regionais são mais expressivos nas classes de renda mais baixas, demonstrando que os diferenciais de fecundidade mostram--se mais 
evidentes em regiões de menor desenvolvimento. Em outras palavras, isto quer dizer que as mulheres situadas nas classes menos favorecidas e residentes em regiões economicamente mais desenvolvidas, ainda têm mais possibilidades de acesso aos mecanismos que proporcionam, de alguma forma, a regulação dos nascimentos do que aquelas residentes em regiões menos desenvolvidas. No outro extremo da distribuição da renda, ou seja, nas categorias mais altas de rendimento familiar, a dimensão regional não parece exercer um efeito que contribua para o surgimento de significativos diferenciais de fecundidade. Neste caso, as taxas de fecundidade total foram estimadas em valores muito próximos de 1 filho por mulher.

Dados do IBGE apontam que a população brasileira vem crescendo a uma taxa de 2,3 filhos por mulher, nível bem próximo ao índice de reposição que é de 2,1. No entanto, segundo ressalta Eluf (2004), constata-se, no Brasil, a existência de regiões muito pobres, onde há mulheres que desenvolvem uma gestação por ano, com possibilidades de ultrapassar 20 gestações até sua menopausa,. São bolsões de crescimento populacional excessivo, presentes não apenas no interior, como também em grandes centros urbanos - as conhecidas favelas. O referido Instituto destaca que, em relação à média brasileira, a população das favelas experimentou crescimento três vezes maior na última década e a principal razão disso foi o aumento da fecundidade. Por sua vez, esse crescimento encontra justificativa em algumas bases apontadas pelo Centro de Políticas Sociais da Fundação Getúlio Vargas, citado pela revista VEJA (09 jun. 2004, p.83), a saber: a primeira é a baixa escolaridade e a ignorância, que dificultam o acesso aos meios para se adquirir anticoncepcionais e às informações sobre como usá-los; a segunda é cultural, pela qual as mulheres se sentem mais respeitadas na vizinhança e os homens mais viris com a geração de muitos filhos; a terceira é econômica, calcada na ilusão de que mais filhos representam maiores chances de sustento para os pais na velhice, por traduzirem maior força de trabalho.

Taxas de fecundidade maiores nas faixas da população de menor renda são motivo de preocupação adicional para o governo, à medida que acarretam impacto direto no cenário sócio-político-econômico do país. Segundo Eluf (2004):

O desenvolvimento econômico é inversamente proporcional ao aumento populacional. As regiões mais pobres do Brasil são as que têm as mais altas taxas de natalidade, enquanto as mais prósperas registram as menores. Quanto mais gente, mais difícil alcançar qualidade de vida, mais complicado combater a pobreza. [...] O resultado disso é que as crianças carentes acabam abandonadas à própria sorte, pelos pais e pela sociedade. Se conseguem sobreviver às vicissitudes da infância, tornam-se 
adultos abandonados que geram mais filhos desamparados. [...] Não há como ignorar o fato de que cada mulher ou menina que engravida, cada criança que nasce, cada família que aumenta precisa de investimento público para sobreviver com um mínimo de decência.

Diante desse quadro, é inegável assumir que cabe ao Estado o relevante papel de esclarecer a população sobre sexualidade e reprodução, de promover a assistência médica gratuita, de prover à população orientação sexual e acesso aos anticoncepcionais e preservativos. Os passos estão sendo dados, mas ainda de forma lenta e incipiente.

O exemplo do preservativo é uma confirmação dessa realidade. Apesar de ser um dos dispositivos mais eficazes para a contracepção e a prevenção contra a Aids, ainda é grande o número de indivíduos sem acesso a esse produto. Pesquisa do Ministério da Saúde $(\mathrm{MS} / \mathrm{IBOPE} 2003)^{3}$, realizada pelo Instituto Brasileiro de Opinião Pública e Estatística sobre a vida sexual do brasileiro, com uma amostra representativa da população com 14 anos ou mais, sexualmente ativa (teve relação sexual nos últimos 6 meses) - , aponta uma redução da proporção dos que tiveram uso consistente do preservativo e destaca que $37,4 \%$ dessa população nunca comprou ou recebeu o produto gratuitamente na rede pública. Nas classes de baixa renda, a proporção daqueles que já compraram o dispositivo também é pequena, chegando a 50,3\% para os indivíduos da classe C e a apenas 37,6\% para os da classe D / E.

Este estudo procura contribuir com a melhoria do acesso da população de baixa renda ao preservativo e entende que, em um primeiro momento, é importante compreender o comportamento de compra do consumidor desse grupo, conhecendo melhor os atributos considerados mais importantes no momento da aquisição. Em um segundo momento, a avaliação dos pesos relativos desses atributos é fundamental para se reunir subsídios para o desenvolvimento de um produto mais adequado às necessidades e aspirações desse consumidor.

Antes, porém, de definir com mais detalhes os objetivos desse estudo, cabe elucidar o conceito de população de baixa renda no contexto apresentado.

\footnotetext{
${ }^{3}$ Relatório parcial Acesso a preservativos distribuídos pela rede pública de saúde e padrão de compra de preservativo. Este e outros documentos da mesma pesquisa, utilizados neste estudo (cf. Bibliografia: Comportamento da população brasileira sexualmente ativa e Uso de preservativos), são citados no texto por meio do nome genérico MS/IBOPE 2003.
} 


\subsection{CRITÉRIOS DE CLASSIFICAÇÃO E CONCEITUAÇÃO DA POPULAÇÃo DE BAIXA RENDA}

Como pode ser observado na seção 2, este estudo não se limita apenas à pesquisa primária, mas recorre em grande escala à investigação de dados secundários. Algumas dessas fontes utilizam critérios diferentes umas das outras para segmentar a população em classes econômicas. No entanto, todas elas consideram de baixa renda o que designam por classes $\mathrm{C}$, D e E, independente do critério de segmentação. Este trabalho adota a mesma posição, pois entende que as diferenças de critério são pequenas e não comprometem as análises.

Trabalho do BCG - BOSTON CONSULTING GROUP (2002), da DATA POPULAR Pesquisa e Consultoria (2004) e do Latin Panel (2002) sobre população de baixa renda no Brasil, que são referências neste estudo, utilizam o agrupamento por classes de rendimento mensal domiciliar (em número de salários mínimos) da PNAD (2002). Todos eles consideram que a população de baixa renda, limitada inferiormente pela classe $\mathrm{E}$ e superiormente pela $\mathrm{C}$, é a que aufere rendimento médio mensal de até 10 salários mínimos.

Por outro lado, a pesquisa MS/IBOPE 2003 e outra, solicitada pelo Ministério da Saúde (2000), ao Centro Brasileiro de Análise e Planejamento - MS/CEBRAP 2000 - ambas referências para este estudo, utilizam o Critério de Classificação Econômica Brasil (CCEB), criado em 1996 pela ANEP - Associação Nacional das Empresas de Pesquisa. Com o objetivo de estimar o poder de compra das pessoas e famílias urbanas, o critério não classifica a população em termos de classes sociais, mas em termos de classes econômicas. É baseado em um sistema que atribui pontos ao entrevistado, conforme a posse de bens em sua residência, e também seu grau de instrução ou do chefe de família, caso não seja ele o entrevistado. Quanto maior o número de bens e mais alto o grau de instrução, maior a pontuação, o que associa o entrevistado a uma classe econômica mais alta. A ocorrência do inverso o enquadra em uma classe mais baixa. O CCEB foi estruturado para definir grandes classes que possam atender às necessidades de segmentação exigidas por quem estuda o mercado. Conforme a própria ANEP pondera, esse critério, como qualquer outro, pode não satisfazer todas as demandas em todas as situações, uma vez que foi construído por meio de técnicas estatísticas, sempre baseadas no coletivo e não no específico. E complementa:

Em uma determinada amostra, de determinado tamanho, temos uma determinada probabilidade de classificação correta (que, esperamos, seja alta) e uma probabilidade de erro de classificação (que, esperamos, seja baixa). [...] Portanto, é de fundamental 
importância que todo o mercado tenha ciência de que o CCEB, ou qualquer outro critério econômico não é suficiente para uma boa classificação em pesquisas qualitativas. Nesses casos, deve-se obter além do CCEB, o máximo de informações (possível, viável, razoável) sobre os respondentes.

Mais detalhes da sistemática do CCEB estão apresentados no Anexo A.

Por ser um critério amplamente aceito pelas empresas de pesquisa de mercado e por já estar consagrado pelo uso, a pesquisa de dados primários desse estudo utilizou o CCEB, e seu instrumento de coleta considerou de baixa renda, conforme já comentado, os indivíduos enquadrados nas faixas C, D e E.

Do ponto de vista da classificação econômica, ainda é conveniente se ater a um detalhe, referente à nomenclatura usada para designar os indivíduos das classes $\mathrm{C}, \mathrm{D}$ e E. Até agora, utilizaram-se os termos consumidor, população e classe de baixa renda. Ao longo do trabalho, no entanto, outras denominações serão encontradas, tais como classe popular e consumidor emergente, referindo-se sempre ao mesmo público em foco. 


\section{METODOLOGIA DO TRABALHO}

Segundo Aaker (2001, p.129), o pesquisador pode lançar mão de diversas fontes de dados para buscar a resposta a suas perguntas. As principais são as primárias e as secundárias.

As secundárias recorrem a dados que foram coletados por terceiros, pessoas ou agências, com outro propósito que não a solução do problema do pesquisador. Constituem-se na maneira mais barata e fácil de busca de informações e devem ser a primeira ferramenta a ter sua disponibilidade averiguada. "A quantidade de dados secundários é enorme e os pesquisadores precisam localizar e utilizar os dados que são relevantes para seu trabalho. A maioria dos procedimentos de busca segue um padrão próprio, que se inicia com as fontes mais disponíveis e baratas" (AAKER, 2001, p.130).

Pode-se recorrer a registros internos ou externos quando se trata de dados secundários. Os internos são referentes a informações gerenciais armazenadas em função do próprio processo de funcionamento de uma empresa, como: informações ligadas a vendas, distribuidores, desempenho de produtos, dentre outras. Os registros externos podem ser obtidos de duas maneiras: por meio de dados publicados e de dados padronizados de marketing. Segundo o referido autor, as principais fontes de publicações são o governo, jornais e revistas, além de relatórios de acesso público de instituições privadas, como fundações, associações profissionais, editoras, sindicatos e empresas, que disponibilizam os dados de forma impressa ou eletrônica. As fontes de dados padronizados referem-se a levantamentos efetuados exclusivamente para usuários comuns de informações, os quais se cotizam no investimento e compartilham os resultados.

As fontes primárias atendem às necessidades imediatas e únicas do pesquisador, o qual precisa de informações específicas não encontradas em outras fontes e que serão geradas pela primeira vez.

Para se alcançar o objetivo deste trabalho, recorreu-se a informações advindas de diversas origens. Lançou-se mão de fontes de dados secundários externos, utilizando-se dados padronizados de empresas privadas a que o autor deste estudo teve acesso. As publicações, tanto de origem impressa quanto eletrônica, constituíram-se em um dos mais importantes recursos para a busca de informações, como no caso dos dados sobre a Aids, sobre a população brasileira e sobre as classes populares; as pesquisas de hábitos e uso de preservativo; e todo o arcabouço teórico que deu base estrutural ao estudo. Recorreu-se 
também a visitas e contatos com empresas especializadas no estudo da população de baixa renda e na fabricação e comercialização de preservativos. Para buscar as respostas específicas levantadas pelo trabalho, buscaram-se dados primários, por meio de pesquisa de campo. 


\section{ESTRUTURA DO ESTUDO}

O planejamento deste estudo levou em conta uma estruturação em partes, com o intuito de torná-lo o mais didático e claro possível.

$\mathrm{Na}$ parte I, são abordados os aspectos gerais do tema, sua importância, a contextualização do assunto, a caracterização da classe de baixa renda, a metodologia de realização do trabalho, como ele está estruturado e os objetivos a serem alcançados.

O referencial teórico é apresentado na parte II. Nela, são enfocados os aspectos mais importantes do que seja o comportamento do consumidor, bem como o processo de tomada de decisão e as variáveis envolvidas. Ainda nessa parte, são apresentados extratos de pesquisas mais específicas sobre o comportamento de uso e de compra de preservativos e os principais embasamentos teóricos sobre marcas e atributos de produto.

A parte III está reservada para uma visão geral sobre a população brasileira e, mais especificamente, sobre as classes de baixa renda. É complementada por uma abordagem do produto preservativo, seu mercado e o comportamento que o brasileiro demonstra em relação a esse produto.

A metodologia da pesquisa de campo aplicada no estudo está retratada na parte IV.

Para a análise e interpretação dos resultados, fica reservada a parte V.

Por fim, na parte VI, são comentados os principais resultados em associação com outras informações de pesquisas. São tecidas as considerações finais e os comentários sobre limitações da pesquisa e recomendações para próximos estudos. A bibliografia utilizada bem como os apêndices e o anexo estão relacionados no final do trabalho. 


\section{OBJETIVOS DO ESTUDO}

Este estudo procura contribuir para o aumento da compreensão do consumidor de baixa renda, explorando seu perfil, seu estilo de vida e a maneira como ele se comporta na hora da compra. O propósito é abordar a compra de preservativos, buscando o entendimento dos usos e costumes em relação ao produto.

Dado o contexto apresentado, por se tratar de um assunto de preocupação pública, órgãos governamentais, como o Ministério da Saúde, já desenvolveram pesquisas para identificar como a população, de um modo geral, e a classe de baixa renda, mais especificamente, usa o produto, explorando os motivos para esse uso, as formas como é feito o acesso à compra e os atributos mais importantes do produto que influenciam a decisão.

De forma específica, o objetivo deste estudo é o de aprofundar o conhecimento dos fatores do produto levados em conta pelas classes de baixa renda no momento da aquisição do preservativo e analisar o peso relativo que cada atributo representa. 


\section{PARTE II}

\section{REFERENCIAL TEÓRICO}

Nesta segunda parte, é apresentado todo o embasamento teórico que vai contribuir para a compreensão do comportamento de compra de preservativos pelo consumidor. Fundamentalmente, são três as vertentes exploradas para referenciar a teoria: os escritos sobre a teoria do comportamento do consumidor, os estudos sobre comportamento de compra e uso de preservativos e a visão conceitual sobre marca e atributos de produto.

\section{ASPECTOS DA TEORIA DO COMPORTAMENTO DO CONSUMIDOR}

Os aspectos a serem abordados estão circunscritos na esfera de duas das mais importantes peças do estudo do comportamento do consumidor: os fatores de influência da tomada de decisão e os processos decisórios de compra.

Antes de começar a discorrer sobre os modelos de comportamento, é oportuno reunir um breve comentário sobre os pressupostos que deram origem às diversas teorias do comportamento do consumidor.

As diversas linhas que tratam do conhecimento do ser humano apresentam visões e pontos de partida diferentes e originarão teorias decorrentes desses diferentes pressupostos. Conforme Giglio (2002, p.47), os estudos consideram uma série de pontos de partida: i-) o ser humano é positivo, com o comportamento direcionado pela racionalidade; ii-) é emocional, sendo dirigido por afetos conscientes e inconscientes; iii-) é social, influenciado pelas regras de grupo; iv-) é dialético, sendo conduzido pelas oposições da existência humana e v-) é complexo, com o comportamento imprevisível em função das determinações e indeterminações que comandam suas decisões.

Esses pressupostos estão relacionados a explicações de consumo. Dentro do escopo deste estudo, é importante destacar as explicações de três dos pressupostos, conforme pode ser visto a seguir. 
No primeiro pressuposto, o fato de o ser humano usar o raciocínio e a lógica leva a ações de marketing calcadas na razão, na comparação de custos versus benefícios e nos processos de aprendizagem e generalização. As teorias do comportamento do consumidor que utilizam esse argumento são as chamadas teorias racionais, e argumentam que "a grande massa dos consumidores teria consciência do seu comportamento e estaria no controle desse comportamento. Segundo os racionalistas, considerar a emoção explicação do comportamento é colocar o maior dom humano num lugar secundário" (GIGLIO, 2002, p. 53). Uma das teorias racionais vem da Economia e considera que o consumo é regido por regras sobre a disponibilidade dos produtos e dos recursos necessários. Um dos aspectos mais importantes para essa teoria é a renda, à medida que pode haver uma relação direta desta com algumas categorias de produto

Outra teoria incluída no primeiro pressuposto, o da abordagem racional e positivista, é a avaliação de risco e decisão, em que a decisão de compra estaria baseada no risco envolvido na operação. "O risco nada mais é do que a possibilidade do resultado ser alcançado, ou não, considerando os esforços financeiros e psíquicos" (GIGLIO, 2002, p.54). O problema dessa linha é a presença de elementos subjetivos, como propensão para assumir riscos, disposição para experimentar o novo, dentre outros.

O positivismo ainda originou uma outra corrente teórica, desenvolvida pela Psicologia, chamada de comportamental ou de behaviorismo que, como sua designação sugere, coloca o comportamento no foco do estudo. É baseada nos fundamentos da teoria de B. F. Skinner e utiliza os conceitos de condicionamento e estímulos. Giglio (2002, p.67) esclarece:

\footnotetext{
Uma confusão muito freqüente sobre o uso do conceito de condicionamento está na diferença entre os estímulos que são apresentados antes da compra e os que são apresentados após. Os primeiros são estímulos eliciadores do comportamento, isto é, que pretendem levar a pessoa a comprar (nem que seja uma vez só), enquanto os segundos são os condicionantes do comportamento, isto é, estímulos que pretendem que as pessoas continuem a comprar após a primeira vez, ou aumentem sua freqüência de compra. Queremos dizer (e aqui nos apoiamos nos experimentos do próprio Skinner) que um comportamento poderá ser incrementado (isto é, sua freqüência aumentada) se for sucedido por uma recompensa importante para o sujeito.
}

O referido autor continua explicando que se o estímulo for condicionante, ou reforçador, como também é chamado, existe a probabilidade do mesmo comportamento se repetir ou até ocorrer com maior freqüência, se for provado que tal estímulo estará presente e 
é importante para o indivíduo a ele submetido. Devido a sua simplicidade e caráter prático, o behaviorismo tornou-se muito presente nas aplicações do marketing. As propagandas de produto, por exemplo, são fortemente usadas como estímulos eliciadores e os brindes póscompra, presentes nas ações promocionais do varejo, os responsáveis pelo condicionamento.

Apesar de os complexos comportamentos humanos terem sido compilados em um modelo simples por essa teoria, ela encontra apoio nos fatos e embasamento lógico, o que não acontece nas teorias da motivação.

As linhas racionais e econômicas são amplamente aceitas, pois permitem criação de medidas e previsão do comportamento, com conseqüente facilidade de aplicação. Por outro lado, são passíveis de muitas críticas, à medida que estão fortemente calcadas em previsão, sendo pouco descritivas e, pela necessidade de mensuração, dão mais enfoque para características do produto, relegando, a segundo plano, as características do consumidor.

O segundo pressuposto, em que a base do comportamento está nas emoções e não na razão, está calcado nas teorias da personalidade formuladas por autores reconhecidos como Freud e Maslow. Giglio (2002, p. 49) distingue as duas, conforme o uso do conceito do inconsciente: "A teoria de Maslow [...] aceita a noção da consciência do sujeito sobre seu comportamento e seus motivos. Já a teoria de Freud coloca as emoções e seus conteúdos ideativos no nível inconsciente". Comentando sobre a teoria de Freud, o autor acrescenta:

\footnotetext{
Depois dos seus escritos (e não só por eles) a fé na consciência e na razão foi seriamente abalada, pois a consciência passou a ser vista como prisioneira do inconsciente, este sim, a verdadeira fonte dos desejos e motor do comportamento. O grande volume de artigos, filmes e obras de arte sobre o inconsciente acabou enfatizando o paradigma da importância secundária da consciência e da razão, colocando em xeque as teorias racionais sobre o consumo.
}

Do ponto de vista prático, por exemplo nas aplicações do marketing, algumas ressalvas devem ser feitas, conforme sugere o autor:

Profissionais de marketing têm utilizado o conceito de inconsciente para criar as mais diversas explicações sobre os motivos de consumo. No entanto, deve-se ter cautela no uso de teorias do inconsciente, pois elas não oferecem instrumentos de avaliação, já que seu conceito fundamental não é operacional (não excluímos aqui seu valor explicativo). [...] Outra conseqüência das teorias da motivação que utilizam o conceito do inconsciente, na forma de conflito dinâmico, é que não há outra 
alternativa senão valorizar o passado do sujeito, em detrimento do presente (que é apenas conseqüência do passado) e do futuro (também dependente do passado). Esse ponto traz uma complexidade para os pesquisadores, que precisam retratar o presente e buscar no passado as variáveis que o explicam.

A teoria de Maslow, da mesma forma que a de Freud, não foi concebida originariamente para explicar o comportamento do consumo. Sua essência é a de que as pessoas apresentam necessidades básicas de vida em níveis de importância independentes, que são priorizados conforme o valor dado por elas. São cinco as necessidades: fisiológicas, de segurança, de afeto, de relacionamento e de auto-realização.

Giglio (2002, p.63) pondera que as duas teorias, apesar de muito conhecidas, passam ao largo da avaliação e ação sobre os consumidores, pois se preocupam mais com o grupamento das necessidades do que com a identificação dos estímulos que são selecionados pela pessoa para satisfazer aquelas necessidades.

O terceiro pressuposto baseia-se na Sociologia, que tem como objetivo entender o comportamento dos grupos e dos indivíduos. Sob essa ótica, o comportamento de consumo pode ser interpretado como um fenômeno social, à medida que a compra de determinados bens pode sofrer a pressão de grupos de influência. O entendimento, portanto, de como se processa essa pressão e de como as relações familiares, sociais e culturais afetam a decisão de compra é a contribuição que a Sociologia pode dar para o estudo do comportamento do consumidor.

No entanto, Giglio (2002, p.77) argumenta que o fato de o comportamento do consumidor ser explicado por variáveis externas, como a cultura e o meio social, não necessariamente facilita as pesquisas. E reforça:

As teorias sobre o que é cultura e grupo social são tão abrangentes e de tão difícil operacionalização que podem ser comparadas às teorias sobre inconsciente ou motivação. Fundamentar que um comportamento foi causado pela cultura do indivíduo pode ser tão difícil quanto argumentar que foi causado por um processo inconsciente (GIGLIO, 2002, p. 77).

Este estudo preocupa-se em compreender como o consumidor de baixa renda se comporta em relação à compra do preservativo, de tal forma que esse produto se torne mais acessível para ele. Trata-se de um produto de mercado e o uso das ferramentas de marketing para se atingir esse objetivo é um caminho lógico. Por isso, tendo em vista a vasta gama de 
teorias de comportamento que respondem aos pressupostos das linhas que ajudam a compreender o ser humano, como observado nesta seção, parece mais apropriado, nesse ponto, aprofundar a discussão, seguindo um modelo de comportamento mais voltado às aplicações de marketing.

Alguns autores desenvolveram modelos obedecendo a essas características. Detalhes adicionais sobre esse assunto são apresentados no próximo tópico.

\subsection{VISÕES CONCEITUAIS DO COMPORTAMENTO DO CONSUMIDOR}

Antes de abordar propriamente os modelos de processo decisório, é importante registrar as visões de alguns autores sobre o conceito de comportamento do consumidor, conforme o que segue:

\footnotetext{
O campo do comportamento do consumidor abrange muitas áreas: é o estudo dos processos envolvidos quando indivíduos ou grupos selecionam, compram, usam ou se desfazem de produtos, serviços, idéias ou experiências para satisfazer necessidades e desejos (SOLOMON, 1998, p. 5).

O comportamento do cliente é definido como as atividades físicas e mentais realizadas por clientes de bens de consumo e industriais que resultam em decisões e ações, como comprar e utilizar produtos e serviços, bem como pagar por eles.
} (SHETH; MITTAL; NEWMAN, 2001, p. 29)

Para Churchill e Peter (2003, p.146), o comportamento do consumidor diz respeito aos "pensamentos, sentimentos e ações dos consumidores e as influências sobre eles que determinam mudanças. O estudo do comportamento do consumidor muitas vezes centra-se no processo de compra deste e na variedade de forças que o modelam”.

Solomon (1998, p.6) salienta que o comportamento do consumidor é um processo, não ocorrendo apenas quando o comprador recebe o bem e executa o pagamento. A transação de troca entre duas ou mais organizações ou entre pessoas também assume papel relevante e expande a visão do processo de consumo, trazendo para análise questões que influenciam o comprador antes, durante e depois da compra. As questões levantadas em cada fase do processo de consumo são ilustradas na Figura 1. 
Figura 1 - Questões envolvidas nas fases do processo de consumo

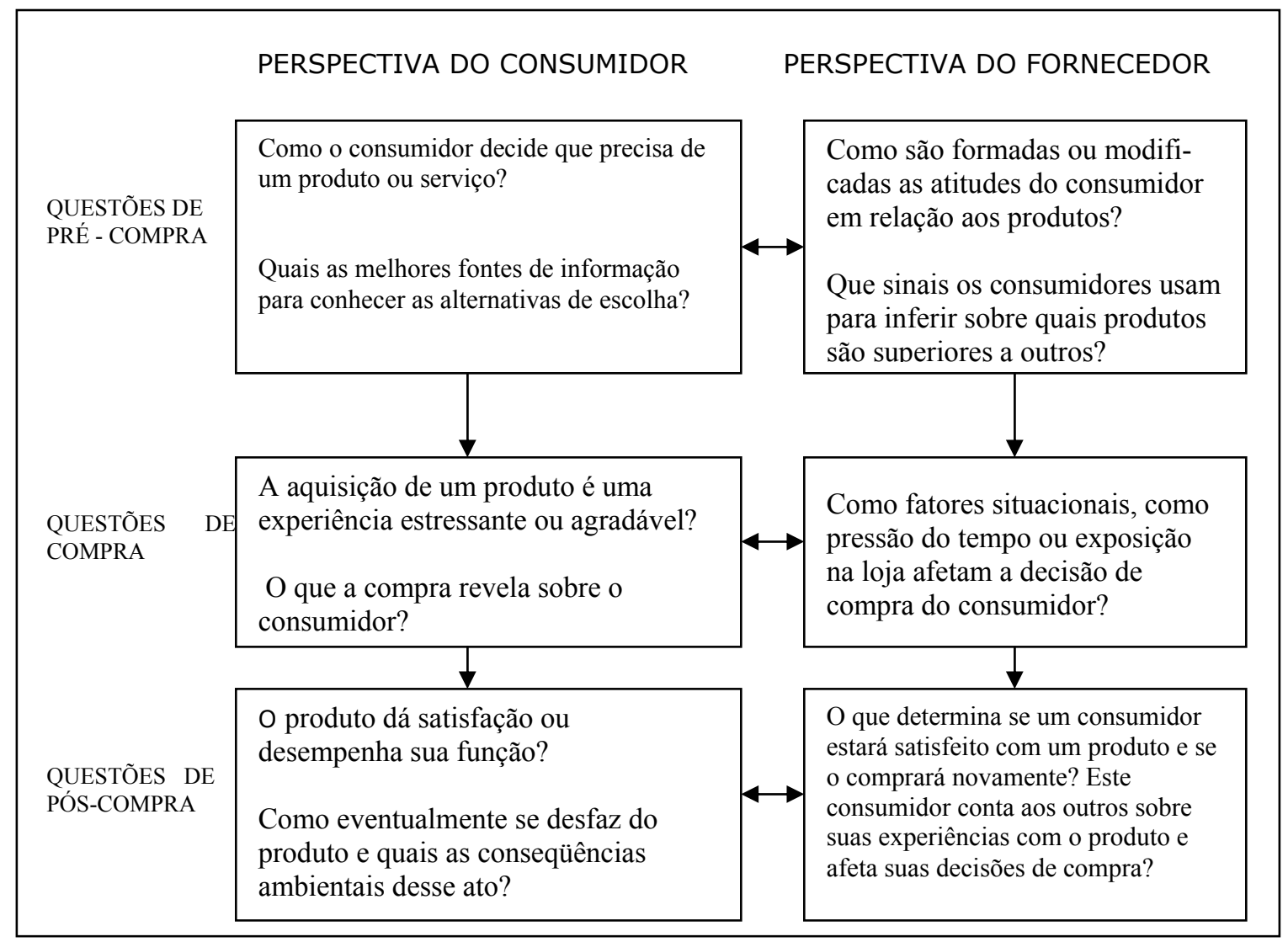

Fonte: SOLOMON, M. R. Consumer Behavior. New York: Prentice Hall, 1998, p.7.

Como se pode notar, o entendimento das variáveis envolvidas no processo de decisão de compra do consumidor parece ser essencial para se discorrer sobre o tema proposto. Dessa forma, torna-se valiosa a análise de alguns autores que tratam do assunto.

\subsection{VARIÁVEIS QUE INFLUENCIAM A TOMADA DE DECISÃO DE COMPRA}

Kotler (2000, p.182) sugere um modelo baseado em estímulo e resposta em que o consumidor, ao ser submetido a estímulos do ambiente e de marketing, toma suas decisões de compra com base em características e processos de decisão próprios. O desafio é entender o que se passa na cabeça do comprador entre o estímulo e a decisão de compra. Esse modelo é ilustrado na Figura 2. 
Figura 2 - Modelo de estímulo e resposta

\begin{tabular}{|c|c|c|c|c|c|}
\hline $\begin{array}{l}\text { Estímulos } \\
\text { de } \\
\text { marketing }\end{array}$ & $\begin{array}{l}\text { Outros } \\
\text { estímulos }\end{array}$ & & $\begin{array}{l}\text { Características } \\
\text { do comprador }\end{array}$ & $\begin{array}{l}\text { Processo de } \\
\text { decisão } \\
\text { do comprador }\end{array}$ & $\begin{array}{l}\text { Decisões do } \\
\text { comprador }\end{array}$ \\
\hline $\begin{array}{l}\text { Produto } \\
\text { Preço } \\
\text { Praça } \\
\text { Promoção }\end{array}$ & $\begin{array}{l}\text { Econômico } \\
\text { Tecnológico } \\
\text { Político } \\
\text { Cultural }\end{array}$ & 百 & $\begin{array}{l}\text { Culturais } \\
\text { Sociais } \\
\text { Pessoais } \\
\text { Psicológicas }\end{array}$ & $\begin{array}{l}\text { Reconhecimento } \\
\text { de problemas } \\
\text { Busca de } \\
\text { informações } \\
\text { Avaliação de } \\
\text { alternativas } \\
\text { Decisão de } \\
\text { compra } \\
\text { Comportamento } \\
\text { após a compra }\end{array}$ & $\begin{array}{l}\text { Escolha do } \\
\text { produto } \\
\text { Escolha da } \\
\text { marca } \\
\text { Escolha do } \\
\text { revendedor } \\
\text { Freqüência de } \\
\text { compra } \\
\text { Montante de } \\
\text { compra }\end{array}$ \\
\hline
\end{tabular}

Fonte: KOTLER, P. Administração de Marketing. São Paulo: Prentice Hall, 2000, p.183.

O modelo de Engel, Blackwell e Miniard (2000, p.92) não é muito diferente. A realidade é representada por meio de variáveis e pela maneira como se inter-relacionam, com a vantagem de fornecer explicações para o comportamento, de apresentar uma estrutura referencial para pesquisa e uma base para sistemas de informações gerenciais e estratégias de marketing.

Segundo os referidos autores, as variáveis que moldam a tomada de decisão passam por fatores e determinantes que são classificados em três categorias: diferenças individuais, influências ambientais e processos psicológicos.

As diferenças individuais podem ser segmentadas em cinco categorias: recursos do consumidor, conhecimento, atitudes, motivação e personalidade, valores e estilo de vida. Os recursos do consumidor dizem respeito ao tempo, ao dinheiro e à capacidade de recepção e processamento de informação. O conhecimento trata das informações armazenadas na memória, que se referem ao produto ou serviço, características, forma e local para compra e modo de usar. As atitudes tratam da avaliação geral de uma marca ou produto e a motivação, da forma como um objetivo (de compra) pode estar ativado. Já a personalidade, os valores e o estilo de vida reúnem um conjunto de traços, crenças e padrões de comportamento individuais que podem caracterizar um segmento de mercado. 
As influências ambientais podem ser de cultura, classe social, influência social, família e situação. As de cultura tratam dos valores e idéias que ajudam os indivíduos a se comunicar, interpretar e avaliar como membros da sociedade. As de classe social voltam-se para a segmentação da sociedade, na qual os indivíduos partilham valores, interesses e comportamento semelhante. As de influência pessoal referem-se a pressões e conselhos daqueles com quem o consumidor se relaciona no seu círculo pessoal. As de família remetem à unidade primária de tomada de decisão. Previsível ou não, a influência situacional é matéria de exploração pelo marketing.

Os processos psicológicos envolvem a Informação em Processamento (como as pessoas recebem, processam e dão sentido às informações), a Aprendizagem (como a experiência leva a mudanças no conhecimento e comportamento) e a Mudança de Atitude e Comportamento.

Mowen e Minor (1997, p.20), na organização do seu modelo de comportamento do consumidor, consideram cinco componentes principais que formam as áreas centrais do estudo: a unidade de compra, o processo de troca, as estratégias do fornecedor, as influências individuais e as influências do ambiente.

As unidades de compra referem-se aos clientes de produtos, serviços, experiências e idéias oferecidas pelos vendedores e se relacionam com eles por meio de um processo de troca. Podem ser constituídas por um indivíduo, uma família, um grupo, ou uma organização com ou sem fins lucrativos capazes de tomar a decisão de compra. Segundo os autores, os princípios do comportamento do consumidor aplicam-se tanto para os negócios business-tobusiness como para os business-to-consumer. No modelo, supõe-se que o vendedor cria uma relação de troca com o consumidor por meio da implementação de uma estratégia de marketing que permita um relacionamento de longo prazo e lucros. Essa estratégia é desenvolvida com base em análises que antecipem os efeitos prováveis dos influenciadores ambientais e também em pesquisas de mercado que fornecem informações sobre os influenciadores individuais.

O modelo liga a unidade de compra a ambos influenciadores. Os fatores de influência individual são os processos psicológicos que afetam os indivíduos em suas experiências de aquisição, compra e descarte de produtos e serviços. Fatores de influência ambiental são aqueles externos ao indivíduo, que afetam os consumidores, as unidades de tomada de decisão 
e os fornecedores. Esses influenciadores alinham-se em um contínuo que vai de um foco extremamente micro para uma abordagem amplamente macro. Os autores argumentam que a análise de marketing deve começar na extremidade indivíduo do contínuo, observando-se os processos psicológicos básicos que envolvem percepção e aprendizagem; move-se pelo contínuo para considerar personalidade, atitudes, persuasão e tomada de decisão do consumidor; neste ponto, o foco do estudo muda do individual para o estudo do impacto de situações e influências grupais sobre o comportamento do consumidor.

O modelo de Mowen e Minor (1997, p.21) pode ser visualizado na Figura 3.

Há outros modelos ainda sugeridos por autores como Shiffman e Kanuk (1997), Sheth, Mittal e Newman (2001) e Churchill e Peters (2003). Cada um apresenta sua particularidade, que será resgatada em situações propícias.

Os modelos de Kotler (2000) e de Engel, Blackwell e Miniard (2000) são bastante consistentes para o propósito deste estudo, além de serem parecidos. Diferenciam-se em algumas abordagens feitas por um e não contempladas pelo outro, porém acabam se completando. Este estudo procura seguir como linha mestra os pontos comuns dos dois modelos, mas não deixa de incluir os pontos exclusivos de cada um. Naturalmente, toda consideração de outro autor julgada pertinente é aproveitada.

Neste estudo, em particular, as características do comprador desempenham papel importante no comportamento de compra. Kotler (2000, p.183) destaca os seguintes fatores componentes das características do indivíduo:

\section{a) Fatores Culturais}

São os que exercem maior e mais profunda influência. Dizem respeito à cultura, subcultura e classe social. Vale ressaltar que o último aspecto ganha destaque especial por estar intimamente ligado ao tema do estudo.

Kotler (2000, p.183) explica que a cultura afeta preponderantemente o comportamento e os desejos da pessoa, já que é o resultado da aquisição, desde cedo, de valores, percepções, preferências e comportamentos da sua família e outras instituições.

Sheth, Mittal e Newman (2001, p.151) apresentam o conceito de cultura como "tudo o que a pessoa aprende e partilha com membros de uma sociedade, inclusive idéias, normas, 
Figura 3 - Um modelo de organização do comportamento do consumidor

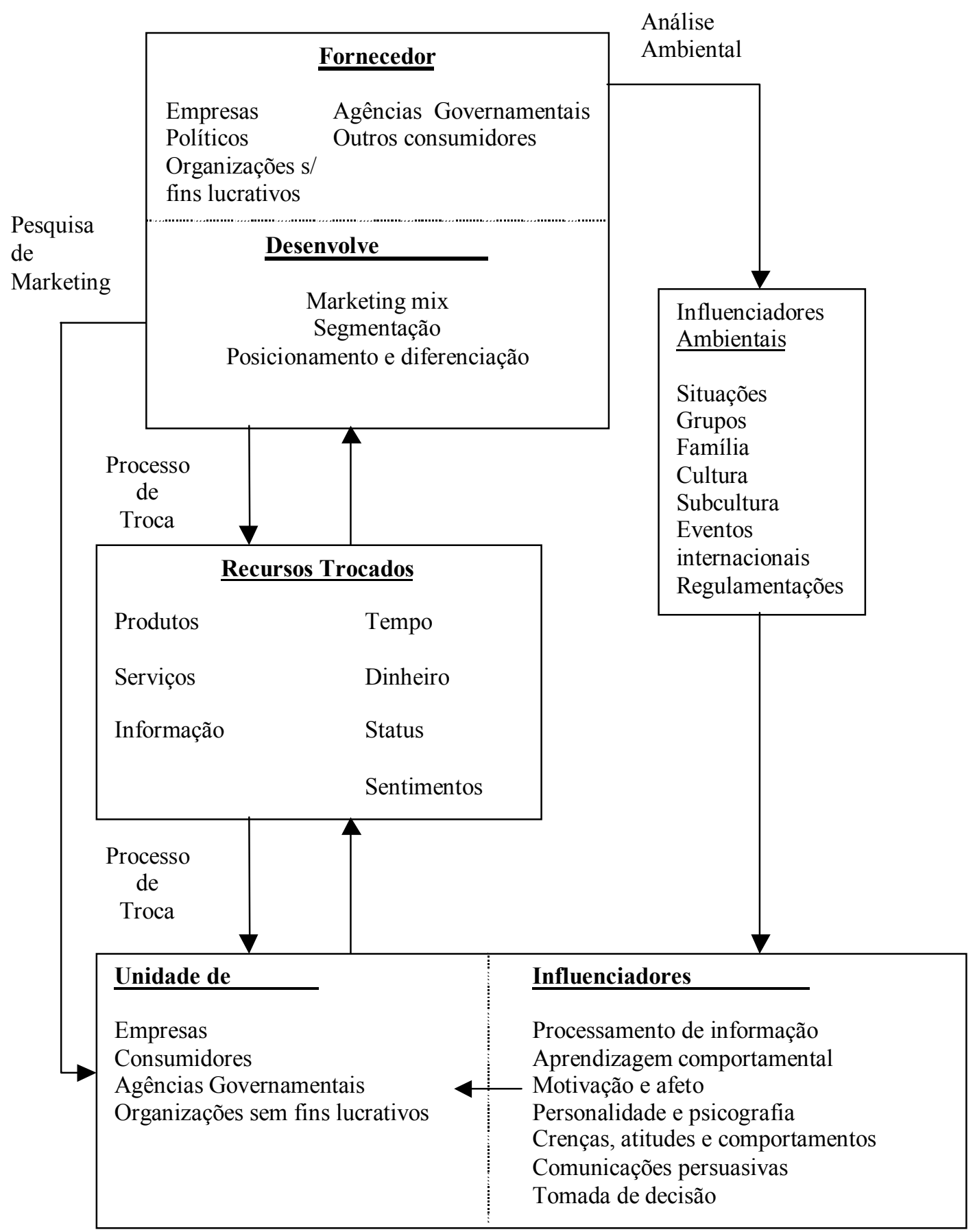

Fonte: MOWEN, J.C.; MINOR, M. Consumer Behavior. New Jersey: Prentice-Hall, 1997. 
moral, valores, conhecimento, habilidades, tecnologia, ferramentas, objetos materiais e comportamentos". Os instintos herdados, por não serem aprendidos, e tampouco os comportamentos, conhecimentos e normas individuais, por não serem compartilhados entre os membros da sociedade, não fazem parte da cultura.

Os autores avaliam que, para se aprender uma cultura, é preciso conhecer seus elementos. Assim, os valores estão ligados ao que é bom e desejável, em oposição ao que é mau e indesejável; as normas dizem respeito às regras de comportamento, isto é, ao que é aceitável e inaceitável; os rituais são um conjunto de comportamentos simbólicos que ocorrem em uma seqüência fixa e tendem a se repetir de tempos em tempos; os mitos são histórias que expressam determinados valores importantes da sociedade.

Para consolidar o conceito de cultura e melhor entender sua influência na compra e no consumo, é oportuno analisar suas principais características. Sheth, Mittal e Newman (2001, p.153) destacam as seis principais.

A primeira é a de que a cultura é aprendida, isto é, os indivíduos não nascem com normas de comportamento, mas as aprendem por meio de imitações ou observações do processo de recompensa e castigo que a sociedade impinge. O comportamento instintivo com o qual nascemos, por exemplo, não faz parte da cultura.

A segunda é a de que a cultura regula a sociedade, isto é, oferece normas e padrões de comportamento e controla os desvios em relação a esses comportamentos.

Um terceiro aspecto é o de que a cultura torna a vida mais eficiente, uma vez que, por ser partilhada, isenta as pessoas da obrigação de aprender novidades a cada situação diferente.

Outras características são as de que a cultura é adaptativa, isto é, molda-se à medida que o ambiente sofre modificações e a de que a cultura é ambiental, ou seja, as pessoas sempre estão envolvidas por uma norma cultural, mas só percebem à medida que essa norma é quebrada.

Por fim, as culturas são compostas por ninhos hierárquicos, o que significa que a cultura de um grupo maior restringe e molda a de um grupo menor envolvida pela primeira.

Neste momento, é importante questionar como a cultura pode afetar o comportamento do consumidor. Engel, Blackwell e Miniard (2000, p.397) argumentam que ela afeta não só os 
produtos comprados, como também a estrutura de consumo, a forma como a decisão é tomada pelo indivíduo e a maneira como a comunicação é feita em uma sociedade.

Vale ressaltar que as pessoas adquirem produtos para obter funcionalidade, forma e significado e este é um aspecto relevante, já que essas são variáveis definidas pelo contexto cultural. A funcionalidade está diretamente associada à qualidade do produto, cujo significado é definido pelo contexto cultural (para algumas culturas, o conceito de qualidade é a durabilidade do produto; para outras, o desempenho é fundamental). Da mesma maneira, a forma do produto é uma expectativa que deve ser atendida para satisfazer o consumidor e é sofre influência de realidades distintas de uma cultura para outra. Símbolos de significado também acompanham o produto, tais como alimentos consumidos em cerimônias religiosas.

Para se chegar mais próximo da razão pela qual um indivíduo compra o que compra, é enriquecedora a compreensão da importância dos valores. No processo de tomada de decisão, como poderá ser visto mais adiante, esses valores podem afetar diretamente não só o reconhecimento de necessidade como também a busca. Engel, Blackwell e Miniard (2000, p.397) utilizam o conceito de valores de consumo para tratar da escolha do consumidor e ressaltam que ela é influenciada por valores funcionais, condicionais, sociais, emocionais e epistêmicos, todos independentes entre si.

Sheth, Mittal e Newman (2001, p. 75) conceituam três dos principais valores da seguinte forma:

Valores funcionais ou de desempenho de um produto ou serviço referem-se ao grau de consistência com o qual sua principal função física é cumprida, isto é, com a qual a qualidade do resultado físico da sua utilização é obtida. Os autores argumentam:

O valor de desempenho consiste na composição física do produto ou no modo como o serviço é estruturado. Depende, portanto, das características de projeto e da qualidade da produção. Muitas escolhas de mercado dependem do grau de valor de desempenho associado a diferentes alternativas. Essa é a posição promovida pela teoria da utilidade em economia, em que o valor de desempenho é geralmente chamado "valor funcional ou utilitário". De acordo com a teoria da utilidade, uma pessoa age racionalmente ao fazer sua escolha. Conseqüentemente, como um "ser econômico racional", um cliente compra produtos que oferecem o máximo valor de desempenho. À medida que o consumidor, pela teoria da utilidade, age racionalmente ao fazer sua escolha, muitas escolhas de mercado dependem do valor de desempenho associado ao produto ou serviço procurado (SHETH, MITTAL; NEWMAN, 2001, p. 75). 
Valores sociais de um produto ou serviço são aqueles que os associam a grupos sociais causadores de uma percepção positiva. Assim, usuários motivados por esse valor escolhem produtos que transmitem uma imagem coerente com a imagem social que desejam projetar. Valores emocionais são aqueles que dizem respeito à satisfação trazida por emoções oferecidas por um produto ou serviço e ao prazer decorrente.

Algumas escolhas são motivadas devido a sua capacidade de satisfazer emoções e os valores emocionais referem-se a essa capacidade.

A subcultura permite identificar e socializar mais especificamente um grupo de pessoas e pode ser classificada com base na nacionalidade, religião, grupos raciais e regiões geográficas.

As classes sociais são divisões de uma sociedade ordenadas hierarquicamente, nas quais seus integrantes possuem valores, interesses e comportamentos similares. Refletem, dentre outros, indicadores como ocupação, grau de instrução e área de residência. Kotler (2000, p.184) continua: “As classes sociais apresentam preferências nítidas por produtos e marcas em diversas áreas [...] e por diferentes meios de comunicação [...]. Há também diferenças de linguagem entre classes."

Segundo Engel, Blackwell e Miniard (2000, p.436), os consumidores associam marcas de produtos e serviços a classes sociais e as divisões na sociedade, por status social, são determinantes no comportamento de compra de consumidor. Empiricamente, destacam, a classe social determina as chances de vida do indivíduo, isto é, suas futuras possibilidades e é nesse sentido que entender seu desenvolvimento é fundamental para a compreensão do consumo.

A comunidade apresenta expectativas por estilo de vida entre cada classe e as reflete por meio da discriminação de grupos de status. Esses grupos são de interesse ímpar para o estudo de marketing, pois exercem influência marcante na forma como as pessoas compram e consomem. Os autores expõem que os estudiosos do consumidor, com base no trabalho do sociólogo Joseph Kahl, enumeraram seis variáveis importantes para se determinar a classe social do consumidor: a ocupação, o desempenho pessoal, as interações, as posses, a orientação de valor e a consciência de classe.

A ocupação pode ser dita como o melhor e mais simples indicador para sugerir uma 
classificação em pesquisa, já que o trabalho de um consumidor afeta muito seu estilo de vida, seu prestígio, está relacionado com a honra e com o respeito. O próprio volume do consumo em si é função da ocupação.

O sucesso, isto é, o desempenho pessoal, influencia diretamente o status de uma pessoa.

Como essência da classe social, destacam-se as variáveis de interação de prestígio pessoal, de associação e de socialização. O prestígio de uma pessoa é reconhecido quando outras pessoas têm atitudes de respeito para com ela; a associação é uma variável que trata de relacionamentos entre pessoas com interesses comuns; socialização diz respeito ao processo de aprendizagem das habilidades, atitudes e costumes que serão praticados no convívio social.

As posses podem ser associadas a classes, não apenas por seu volume, mas pela natureza das escolhas feitas pelos indivíduos. Em geral, produtos e marcas são símbolos de status e sua compra pode ser resultado de uma busca por afiliação ou identificação.

A orientação de valor também indica a classe social à qual se pertence. Os autores mencionados anteriormente referem-se a valores como crenças sobre como as pessoas devem se comportar e, quando um grupo de pessoas desfruta das mesmas crenças, é possível se enquadrar um indivíduo pelo grau de afinidade a esses valores.

Por fim, a consciência de classe, isto é, o grau em que as pessoas têm consciência de si mesmas como pertencentes a um grupo com interesses políticos e econômicos comuns, também constitui variável importante de determinação de classe social.

\section{b) Fatores Sociais}

Kotler (2000, p.185) destaca que os fatores sociais representam importância significativa neste estudo, pois dizem respeito aos grupos de referência, família, papéis sociais e status que, no caso, trazem forte impacto sobre o comportamento do consumidor.

\section{b.1) Grupos de Referência}

Os grupos de referência exercem influência sobre as atitudes ou o comportamento de uma pessoa. Tanto Kotler (2000, p.185) como Engel, Blackwell e Miniard (2000, p.461) tipificam tais grupos conforme apresentado a seguir. 
Quando as influências são diretas, isto é, há interações irrestritas cara a cara, os grupos são ditos de afinidade e podem ter duas classificações: primários, caso da família, dos amigos, dos vizinhos e colegas de trabalho, com os quais a pessoa interage contínua e informalmente, há coesão e participação motivada e os membros exibem semelhanças em comportamentos e crenças; e secundários, como nos grupos religiosos, profissionais e associações de classe, em que normalmente a interação é formal, menos contínua e menos influente.

Os grupos aos quais não pertencem também influenciam as pessoas. Quando o indivíduo deseja seguir normas, valores e comportamentos de outros a quem espera se associar, está sendo afetado por um grupo aspiracional, cuja influência não é direta, mas pode interferir significativamente no processo de escolha de um produto. Por sua vez, quando a pessoa rejeita valores e comportamentos de uma associação de indivíduos, diz-se que ela se constitui um grupo dissociativo.

Por último, os grupos classificam-se em formais, quando seus membros podem ser listados e sua estrutura organizacional pode ser definida por escrito, caso das igrejas e organizações comunitárias; ou informais, quando não há uma estrutura clara e as normas não são colocadas por escrito.

Os grupos de referência fazem diferença, à medida que expõem a pessoa a novos comportamentos e estilos de vida, afetam as atitudes e a auto-imagem e pressionam em relação à conformidade que pode afetar as escolhas reais de produto e marca.

Um produto ou marca fortemente influenciado por um grupo de referência pressupõe uma ação de marketing sobre os líderes de opinião desse grupo. Esses líderes são encontrados em todos os estratos sociais, fazendo divulgação informal, oferecendo conselhos ou informações sobre um produto ou categoria de produtos específicos.

Segundo Engel, Blackwell e Miniard (2000, p.462), os grupos de referência afetam a escolha do consumidor de algumas maneiras distintas.

A primeira delas ocorre quando há pressão por conformidade e concordância e é o que se chama de aquiescência normativa. Pode se dar por pressão normativa propriamente dita, quando o indivíduo, ao obedecer a certa regra, percebe que aufere recompensas diante dos custos da sua decisão; pode ocorrer quando há forte motivação por aceitação social, em que o indivíduo se preocupa com a adequação de suas ações, atenta para a comparação social no 
intuito de apresentar auto-expressão aceitável e se mostra disposto a modificar tal auto-expressão e auto-apresentação, conforme necessário; mas essas duas formas só são suficientes na influência do comportamento quando houver ostensividade na compra e uso do produto ou serviço.

A segunda ocorre quando os grupos exercem função de expressão de valor, isto é, influenciam o indivíduo com necessidade de ter associação psicológica com eles a aceitar suas normas, valores ou comportamentos.

A última maneira é a da influência informacional, em que se evidencia, geralmente, a aceitação, por parte do consumidor, de opiniões de grupos como sendo fortes e confiáveis referências sobre a realidade.

Engel, Blackwell e Miniard (2000, p.469) ainda destacam a importância de se considerar a influência do boca-a-boca nas escolhas do consumidor. É freqüente o indivíduo recorrer a amigos ou familiares em busca de informações sobre produtos ou serviços e encontrar suas respostas no influenciador, isto é, em quem transmite a opinião sobre o assunto. Com base em pesquisas, esse tipo de influencia ocorre com maior probabilidade em situações em que o consumidor não tem informação suficiente, o produto é de difícil avaliação por meio de critérios objetivos, a pessoa não apresenta capacidade técnica de avaliação, outras fontes de informação são de baixa credibilidade, existe um influenciador mais acessível que outras fontes, há laços sociais fortes entre o transmissor e o receptor da opinião e o indivíduo tem uma forte necessidade de aprovação social.

Engel, Blackwell e Miniard (2000, p.466), abordando os modelos de influência pessoal, contribuem significativamente com o assunto, elucidando que a teoria apresenta três aspectos distintos em sua funcionalidade.

O primeiro é o da teoria corrente abaixo, antiga linha de pensamento que defende que as classes inferiores geralmente apresentam comportamentos similares aos de seus correspondentes das classes superiores, em uma situação que caracteriza a transmissão de influência verticalmente por meio das classes.

O segundo é o do fluxo de dois passos, resultado da observação de que novas idéias e influências fluem dos meios de comunicação de massa para os influenciadores, e destes, pelo boca-a-boca, para os mais passivos, na busca de informação e menos expostos aos meios de comunicação. 
O terceiro aspecto contrapõe-se ao modelo do fluxo de dois passos, ao referendar pesquisas que demonstram que tanto influenciador quanto influenciado são afetados pelos meios de comunicação de massa e que, raramente, aquele é o intermediário do conteúdo da mensagem.

\section{b.2) Família}

Os membros da família constituem o grupo de referência primário mais influente. Kotler (2000, p.187) aponta que, na vida do comprador, podem ser percebidas duas famílias: a de orientação, na qual se nasce, e que consiste nos pais e irmãos e de quem se adquire orientação em relação à religião, à política e à economia e uma noção de ambição pessoal, valor pessoal e amor; a de procriação, a estabelecida por casamento, que consiste no cônjuge e nos filhos e que exerce uma influência mais direta no comportamento de compra diário.

Engel, Blackwell e Miniard (2000, p.477) acrescentam ainda duas outras formas de se classificar uma família: a família nuclear, grupo imediato formado por pai, mãe e filhos que vivem juntos, e a família ampliada, complementação da nuclear com os outros parentes. Além disso, apresentam o conceito de domicílio como o de um grupo de pessoas, aparentadas ou não, que vivem sob um mesmo teto. A escolha do consumidor é influenciada por variáveis de família ou domicílio - que podem ser estruturais como a idade do chefe, o estado civil, a presença de filhos, o status de emprego, ou sociológicas - que dizem respeito à coesão, adaptabilidade e comunicação. A coesão é o grau de ligação emocional entre os membros da família; a adaptabilidade é a capacidade de uma família mudar sua estrutura de poder, seus papéis e as regras de relacionamento para responder a mudanças de necessidades; e a comunicação é a variável facilitadora que permite a ocorrência das outras duas.

No contexto do estudo do comportamento do consumidor, é importante ressaltar as funções da família. Schiffman e Kanuk (1997, p.347) destacam quatro funções relevantes: prover bem-estar econômico, fornecer suporte emocional, estabelecer estilos de vida adequados para a família e promover a socialização dos seus membros.

O bem-estar econômico é função básica e está relacionado com a maneira como os dependentes dividem responsabilidades para cumpri-la. O papel econômico, tanto da esposa como dos filhos, vem mudando ao longo do tempo e isso tem influenciado decisivamente para a mudança do comportamento de consumo, à medida que novos membros da família passaram a ter poder aquisitivo e a representar um novo foco de interação com o mercado. 
"O suporte emocional faz parte das funções da família moderna como forma de ajudar seus membros a enfrentar os problemas pessoais, sociais e de tomada de decisão" (SCHIFFMAN; KANUK, p.347). À medida que passou a existir essa necessidade, novos produtos e serviços, como os psicológicos, por exemplo, surgiram para satisfazê-la e sugeriram novas formas de comportamento e relacionamento com o mercado.

Educação, experiência, metas pessoais e conjuntas dos cônjuges acabam por determinar a importância dada à educação, carreira, aprendizagem, hábitos de leitura, avaliação da qualidade dos produtos e serviços adquiridos, o que, em última análise, reflete o estilo de vida impresso pela família. Esse estilo, naturalmente, afeta, de forma decisiva, o comportamento de compra do indivíduo.

Uma função central da família é, sem dúvida, a socialização dos seus membros. Abrange desde as crianças até os adultos. No caso das crianças, inclui a transmissão dos valores básicos e as formas de comportamento consistentes com a cultura, como princípios morais e religiosos, habilidades interpessoais, padrões de vestimenta, boas maneiras, dentre outros. Particularmente relevante para esse contexto da criança é a socialização do ponto de vista de consumidor, que é definida como "o processo pelo qual a criança adquire habilidades, conhecimentos e atitudes necessárias para atuarem como consumidores" (SCHIFFMAN; KANUK, p.350). Muitas crianças e pré-adolescentes adquirem normas de comportamento de consumo por meio da observação de seus pais e irmãos, que funcionam como modelo, enquanto os adolescentes, mais provavelmente, buscam em seus amigos os modelos de comportamento aceitável.

Para uma família cumprir com suas funções, um ou mais membros precisam desempenhar papéis. Engel, Blackwell e Miniard (2000, p.479) destacam que esses papéis podem ser assumidos pelo marido, esposa, filhos ou outros componentes de um domicílio e que tanto papéis múltiplos como atores múltiplos podem ocorrer. Pelo menos cinco papéis são apontados pelos autores, a saber: iniciador, influenciador, decisor, comprador e usuário. A essa lista, Schiffman e Kanuk (1997, p.353) acrescentam quatro importantes itens, em uma abordagem um pouco mais detalhada: porteiro, preparador, zelador e descontinuador.

$\mathrm{O}$ iniciador é aquele que lança à família o pensamento da compra do produto ou serviço e o da coleta de informações para a tomada de decisão. O influenciador é o componente procurado para opinar sobre os critérios de decisão a serem adotados e sobre os 
produtos ou marcas a serem adquiridos segundo tais critérios. O porteiro é quem controla o fluxo de informação sobre o produto ou serviço que chega para dentro da família. O decisor é o indivíduo com poder para determinar unilateralmente ou conjuntamente qual e se um específico produto ou serviço deve ser comprado, usado, consumido ou descartado. O comprador é o responsável pela operação de compra propriamente dita, visitando o ponto de venda, contatando os fornecedores, efetivando o pagamento e até trazendo o produto. $\mathrm{O}$ preparador é quem transforma o produto ou serviço em uma forma apropriada para uso, caso não chegue assim do fornecedor. O usuário é quem usa ou consome um determinado produto ou serviço. O zelador é quem se responsabiliza pelos reparos, de tal forma a garantir satisfação contínua com o uso do produto. O descontinuador é o membro da família que inicia e conduz o processo de descarte de um determinado produto ou serviço.

\section{b.3) Papéis e Status}

Segundo Kotler (2000, p.189), como uma pessoa participa de muitos grupos, a posição dela em cada um pode ser definida em termos de papéis e status. Um papel diz respeito às atividades desempenhadas por uma pessoa e carrega consigo um status. A escolha de produtos pelo consumidor dá-se em função dos papéis e status que eles comunicam na sociedade.

Solomon (1998, p.5) segue a mesma linha, citando a teoria dos papéis A perspectiva da teoria de papéis considera a visão de que muito do comportamento do consumidor assemelha-se à atuação em uma peça teatral. Como as pessoas desempenham muitos papéis diferentes no seu dia-a-dia, às vezes suas decisões de consumo são alteradas, dependendo da situação de momento. Em um dos seus papéis, o critério usado para avaliarem produtos e serviços pode diferir em relação ao adotado em outro papel.

\section{c) Fatores Pessoais}

Outro fator de influência nas decisões de compra do consumidor destacado por Kotler (2000, p.189) diz respeito às características pessoais como idade e estágio do ciclo de vida, ocupação, circunstâncias econômicas, estilo de vida, personalidade e auto-imagem. São os fatores pessoais.

O autor considera que os padrões de consumo são moldados de acordo com o ciclo de vida da família, havendo nove estágios nesse ciclo: solteiro (jovem que não mora com a 
família), recém-casados (jovens sem filhos), ninho cheio I (filhos com menos de seis anos), ninho cheio II (filho caçula com seis anos ou mais), ninho cheio III (casais mais velhos com filhos dependentes), ninho vazio I (casais mais velhos, sem filhos morando junto e o chefe de família ainda com atividade profissional), ninho vazio II (casais ainda mais velhos, sem filhos em casa e o chefe de família aposentado), sobrevivente solitário em atividade profissional e sobrevivente solitário aposentado. Além disso, influencia a situação financeira e os interesses de cada grupo no estágio de ciclo de vida por produtos típicos.

A ocupação já foi tratada anteriormente e enquadrada por Engel, Blackwell e Miniard (2000, p.439) como variável de determinação de classe social. Kotler (2000, p.190) propõe ainda que a escolha de produto também possa ser afetada pelas circunstâncias econômicas como renda disponível, economias e bens, débitos e capacidade de endividamento e atitude em relação a gastar versus economizar.

Embora as pessoas possam ter a mesma ocupação, ser da mesma classe social e ter a mesma cultura, seus estilos de vida podem ser completamente diferentes. O estilo de vida diz respeito ao padrão de vida e se reflete nas atividades, interesses e opiniões do indivíduo. Há grupos de estilo de vida discriminados por meio de métodos psicográficos, que apresentam tendências específicas. Os segmentos de estilo de vida, no entanto, não são universais, podendo haver classificações distintas em diversas partes do globo.

A personalidade da pessoa é outro fator que influencia o comportamento de compra e se refere a "características psicológicas distintas, que levam a reações relativamente coerentes e contínuas no ambiente", conforme Kotler (2000, p.193), como a autoconfiança, o domínio, a autonomia, a submissão, dentre outros. Esse fator é fundamental para a avaliação do comportamento do consumidor, porque é possível classificar com precisão os tipos de personalidade e se identificar correlações entre tipos de personalidades e escolhas de produtos e marcas.

Mowen e Minor (1997, p.200) discorrem sobre o tema, destacando quatro aspectos fundamentais da personalidade. O primeiro deles enfatiza a necessidade de o comportamento da pessoa se mostrar consistente ao longo do tempo para poder se chamar personalidade. $\mathrm{O}$ segundo chama atenção para o fato de que os comportamentos devem distinguir uma pessoa das outras, isto é, uma característica de personalidade não pode estar presente em todos os consumidores. O terceiro assinala que características de personalidade não estão rigidamente associadas a tipos de comportamento, ou seja, não é possível prever um comportamento de 
compra por meio de uma simples medida de personalidade em uma determinada situação; é necessário que se leve em conta a interação de personalidade, situação e produto. O quarto aspecto é que a personalidade modera os efeitos das mensagens de propaganda e ações de marketing no comportamento do comprador.

Auto-imagem.é um aspecto relacionado com a personalidade e que está envolvido no processo decisório de compra. Como os produtos apresentam imagens, ao realizar uma compra, a pessoa tenta satisfazer sua auto-imagem. Kotler (2000, p.193) pondera, no entanto, que a auto-imagem real da pessoa (a maneira como ela se vê) pode ser diferente da sua autoimagem ideal (a maneira como ela gostaria de se ver) e da sua auto-imagem de acordo com os outros (como ela pensa que os outros a vêem). Em um processo de compra, portanto, não se sabe ao certo qual auto-imagem o produto ou marca estão satisfazendo.

\section{d) Fatores Psicológicos}

Kotler (2000, p.193) destaca que as decisões de compra de uma pessoa são influenciadas por quatro fatores psicológicos básicos: motivação, percepção, aprendizagem e crenças e atitudes.

\section{d.1) Motivação}

"Um motivo é uma necessidade suficientemente importante para levar uma pessoa a agir" (KOTLER, 2000, p.194). O autor aponta três das mais conhecidas teorias sobre motivação humana:

1. A teoria de Freud apregoa que as forças psicológicas que formam o comportamento das pessoas são inconscientes e que uma pessoa não pode entender completamente suas motivações. Ao avaliar uma marca, por exemplo, outros sinais menos conscientes estão presentes e influenciarão a análise, além dos impulsos sugeridos pela marca.

2. A teoria de Maslow afirma que "as necessidades humanas são dispostas em uma hierarquia, da mais urgente para a menos urgente. [...]. Quando uma pessoa consegue satisfazer uma necessidade importante, essa necessidade deixa de ser um motivador corrente e a pessoa tenta satisfazer a próxima necessidade mais importante" (KOTLER, 2000, p.194). $\mathrm{Na}$ escala de importância, as necessidades são fisiológicas, de segurança, sociais, de estima e de auto-realização. Essa teoria permite entender a relação entre os produtos e seus consumidores à medida que faz parte dos seus planos e objetivos de vida. 
3. A teoria de Herzberg trata de dois fatores: os "insatisfatores" (que causam a insatisfação) e os "satisfatores" (que causam a satisfação). A falta de insatisfatores não basta para motivar uma compra; os satisfatores devem estar presentes e são os motivadores principais da compra de um produto.

Engel, Blackwell e Miniard (2000, p.267) enfocam a dinâmica do processo de motivação também a partir do reconhecimento de uma necessidade, que consideram a variável central do processo de motivação. A necessidade é ativada ou sentida quando o indivíduo percebe a diferença entre o estado ideal e o estado atual; o aumento dessa discrepância faz surgir uma condição de despertar, chamada impulso, que é dirigido para atender certas metas aprendidas como incentivos. Quanto maior o impulso, maior a urgência por uma resposta. $\mathrm{O}$ padrão de comportamento ou a forma pela qual o indivíduo satisfaz sua necessidade é chamada desejo. Podem-se identificar dois tipos de necessidades sentidas: as utilitárias, que consideram atributos ou benefícios de produtos, e as hedonistas / vivenciais, que abrangem fantasias, prazeres e considerações estéticas subjetivas.

É oportuno, neste ponto, abordar o papel motivacional do envolvimento. Segundo Engel, Blackwell e Miniard (2000, p.268) trata-se do "nível de importância pessoal ou interesse evocado por um estímulo numa dada situação". O envolvimento, em última análise, é reflexo da motivação do consumidor para reduzir seus riscos e maximizar os benefícios da compra e uso do produto ou serviço; ou seja, é tanto maior quanto maior for a relevância pessoal dada ao produto ou serviço.

Não menos importante é a questão do afeto, apontado por Engel, Blackwell e Miniard (2000, p.268) como uma associação de sentimentos, emoções e humores que moldam os resultados comportamentais. Essas influências formam estados de sentimentos positivos ou negativos que afetam o comportamento de compra de formas distintas, acelerando o processamento de informação e reduzindo o tempo de decisão ao selecionar a compra, associando produtos a sensações positivas ou ativando um estado de impulso.

Mowen e Minor (1997, p.160) definem motivação como "um estado ativado na pessoa que leva a um comportamento dirigido a um objetivo". Consiste de necessidades, desejos e sentimentos, que são os iniciadores de uma seqüência de eventos capazes de levar ao comportamento. Um modelo simplificado do fluxo de eventos que ocorrem quando o consumidor passa pela experiência do estado de motivação pode ser melhor visualizado na 
Figura 6, em que são apresentados cinco conceitos fundamentais: reconhecimento da necessidade, estado de ação, comportamento direcionado por objetivo, objetos de motivação e afeto.

A motivação inicia-se com a presença de estímulos que geram o reconhecimento de uma necessidade. Esses estímulos podem ser internos ou externos ao consumidor e, se causarem uma divergência entre a situação desejada e a situação real do consumidor, o resultado é o aparecimento da necessidade.

Há dois tipos de necessidades identificadas pelos estudiosos: as de expressão, que se referem ao desejo do consumidor de atender a exigências sociais e estéticas e que estão associadas à manutenção do auto-conceito pessoal; e as utilitárias, que se referem a desejos de resolver problemas básicos.

Quando uma necessidade é levantada, um estado de ação é produzido. Um estado de ação pode ser assim caracterizado:

[...] um estado afetivo no qual a pessoa passa por emoções e excitação psicológica [...]. O nível de um estado de ação influencia o nível pessoal de envolvimento e o estado afetivo. Intensificando-se o estado de ação, aumentam os sentimentos e emoções, resultando em maiores níveis de envolvimento e processamento de informação. (MOWEN; MINOR, 1997, p. 162).

Ao vivenciar um estado de ação, o indivíduo é levado a um comportamento direcionado por objetivo, que "consiste em ações adotadas para aliviar o estado de necessidade do indivíduo" (MOWEN; MINOR, 1997, p. 162).

No estudo do comportamento em geral e neste estudo em particular, abordar a motivação por experiências hedônicas é valioso.

O desejo por experiências hedônicas está intimamente ligado à necessidade do consumidor manter um nível ótimo de estímulo. Na pesquisa do consumidor, o consumo hedônico se refere à necessidade dos consumidores usarem produtos e serviços para criarem fantasias, sentirem novas sensações e obterem excitação emocional. (MOWEN; MINOR, 1997, p.173).

Estudiosos do consumo hedônico ressaltam que os desejos emocionais às vezes sobrepõem motivos práticos quando os consumidores escolhem seus produtos. As pessoas procuram vivenciar uma variedade de emoções como amor, raiva, medo, dentre outras. 
Ainda dentro do espectro da teoria de motivação, o risco percebido é um fator relevante na tomada de decisão de compra. Pode ser conceituado como "uma percepção do consumidor da negatividade total do curso de ação baseada na avaliação de possíveis resultados negativos e da sua probabilidade de ocorrer" (MOWEN; MINOR, 1997, p.176).

Mowen e Minor (1997, p. 179) destacam que os tipos de riscos que normalmente afetam os consumidores e são de interesse para os profissionais de marketing, de tal forma que possam minimizá-los, são: financeiros, de desempenho (produto), físicos (ferimentos), psicológicos (auto-imagem), sociais (o que os outros vão pensar), de tempo (duração da decisão) e de perda de oportunidade (por não estar tomando outra decisão). Os autores acrescentam que a percepção do risco em uma compra pode aumentar se o produto é caro em termos econômicos ou de tempo; outros vão avaliar o comprador pela marca adquirida; os consumidores têm satisfação em possuir o produto, podem se machucar física, psicologicamente ou socialmente; os consumidores têm que desistir da compra de outro produto; a atividade é de natureza involuntária e o resultado está fora de controle do consumidor.

\section{d.2) Percepção}

A percepção da situação influencia a maneira pela qual a pessoa age, a partir do momento em que está motivada para agir. Trata-se do "processo pelo qual a pessoa seleciona, organiza e interpreta as informações recebidas para criar uma imagem significativa do mundo" (KOTLER, 2000, p.195). A percepção está intrinsecamente ligada ao indivíduo, podendo ser diferente de pessoa para pessoa, quando observado um mesmo fato ou objeto, em função de três processos: atenção seletiva, em que as pessoas filtram os inúmeros estímulos que recebem; distorção seletiva, em que mesmo os estímulos percebidos são transformados em significados pessoais e interpretados de forma a se adaptar aos pré julgamentos; retenção seletiva, em que há propensão à lembrança apenas dos pontos positivos percebidos.

Na visão de Sheth, Mittal e Newman (2001, p.290), os processos que afetam a percepção das pessoas envolvem a exposição seletiva, em que o indivíduo escolhe expor-se seletivamente a um impulso; a atenção seletiva, que obedece à mesma concepção de Kotler (2000, p.195) e a interpretação seletiva, que corresponde à distorção seletiva do mencionado autor. Aparentemente, as duas abordagens se complementam.

\section{d.3) Aprendizagem}

A aprendizagem está relacionada com as mudanças no comportamento de uma pessoa, 
advindas da vivência de uma situação. Kotler (2000, p.196) explica que os estudiosos do assunto acreditam que ela é o resultado da interação de impulsos, estímulos, sinais, respostas e reforços. E, para detalhar, conceitua impulso como um forte estímulo interno que impele à ação; sinais, como sendo estímulos menores que determinam quando, onde e como uma pessoa reage; resposta, como a reação a um estímulo; e reforço, como a generalização da resposta a estímulos semelhantes. Neste ponto, acrescenta que uma tendência oposta à generalização é a discriminação e ocorre quando a pessoa aprende a reconhecer diferenças em séries de estímulos semelhantes e é capaz de adaptar suas respostas de acordo com isso.

A abordagem de Sheth, Mittal e Newman (2001, p.297) dada ao assunto inclui quatro modelos de aprendizado.

O primeiro é o cognitivo, que se refere à aquisição de informações por meio de comunicações orais ou escritas e é a forma mais freqüente com que o consumidor aprende sobre produtos antes de comprar. Pode ser de dois tipos: memorização mecânica, por meio do esforço ativo ou exposição passiva e repetida à informação ou solução de problemas, em que o indivíduo trabalha a informação por meio da ponderação, avaliação, combinação e integração de fragmentos divergentes da informação e chega a uma conclusão.

O segundo é o condicionamento clássico, apresentado como "o processo em que uma pessoa aprende uma associação entre dois estímulos em virtude de sua constante aparição como um par" (Sheth; MitTal; Newman, 2001, p.298). Passando para a linguagem de marketing e exemplificando, um estímulo condicionado, isto é, aquele para o qual o cliente não apresenta uma resposta preexistente, por exemplo, um produto ou serviço em aquisição, pode ser associado a um estímulo incondicionado, isto é, aquele para o qual o cliente já apresenta resposta específica preconcebida, por exemplo, uma música que traz tranqüilidade. A tendência do cliente será a de transferir ao estímulo sem resposta preexistente a sensação ou resposta do outro estímulo.

O terceiro é o condicionamento instrumental, em que as maneiras pelas quais a pessoa aprende a responder é função das recompensas trazidas por elas. O melhor exemplo desse tipo de aprendizado no âmbito do marketing são os programas de milhagem das companhias aéreas, os sorteios, os concursos e as ofertas.

O quarto é a moldagem, em que um indivíduo aprende por meio da observação do outro. Trata-se da imitação do comportamento de outras pessoas, que são vistas sendo 
recompensadas, por pessoas que almejam o mesmo tipo de recompensa. Os autores citam Miller e Dollard como psicólogos que, dentre outros feitos, identificaram quatro classes de pessoas que tendem a ser imitadas por outras: os hierarquicamente mais velhos, os superiores em status social, os superiores em inteligência e os técnicos superiores em qualquer campo.

\section{d.4) Crenças e Atitudes}

Como resultado do processo de aprendizagem, Kotler (2000, p.196) lembra que as pessoas acabam por adquirir crenças e atitudes capazes de influenciar o comportamento de compra. "Uma crença é o pensamento descritivo que uma pessoa mantém a respeito de alguma coisa", baseado em conhecimento, opinião ou fé, contendo ou não carga emocional. As pessoas apresentam comportamentos de compra de acordo com imagens de marcas e produtos, produzidas por crenças. Por sua vez, "uma atitude corresponde a avaliações, sentimentos e tendências de ação duradouros, favoráveis ou não a algum objeto ou idéia" (KOTLER, 2000, p. 197). Uma atitude leva uma pessoa a se comportar de maneira relativamente coerente com objetos ou idéias semelhantes, sendo difícil de ser mudada.

Aprofundando-se mais nesse assunto, Mowen e Minor (1997, p.242) buscam, no estudo da formação de crenças do consumidor, o entendimento da relação entre crenças, atitudes e comportamentos.

As crenças do consumidor são todo o conhecimento e inferências que o consumidor tem a respeito de objetos, seus atributos e seus benefícios. Objetos são produtos, pessoas, empresas e coisas sobre as quais as pessoas apresentam crenças e atitudes. Atributos são as características ou aspectos que um objeto pode ou não pode ter. [...]. Finalmente, benefícios são resultados positivos que os atributos oferecem ao consumidor.

É difícil saber quais atributos são mais valorizados pelos consumidores quando avaliam uma marca, já que as crenças sobre objetos, atributos e benefícios dizem respeito a percepções e, por isso, elas são diferentes de um consumidor para outro. Tais crenças estão baseadas na aprendizagem cognitiva e podem ser classificadas em três tipos. O primeiro são as crenças objeto-atributo, que associam um atributo a um objeto, pelo conhecimento de que um objeto possui um particular atributo. $\mathrm{O}$ segundo são as crenças atributo-benefício, que representam a percepção que o consumidor tem da medida do benefício que um particular benefício pode apresentar. O terceiro são as crenças objeto-benefício, que representam a 
percepção que o consumidor tem do quanto um particular produto, pessoa ou serviço pode gerar um benefício específico.

Embora os consumidores reúnam crenças sobre um produto, elas podem não corresponder à realidade, devido a percepções distorcidas que venham a ter a respeito dos atributos desse produto. Os efeitos de halo exemplificam esse caso, à medida que ocorrem quando "os consumidores presumem que, se o produto é bom ou ruim em certa característica, também será bom ou ruim em outra característica” (MOWEN; MINOR, 1997).

Para esse estudo em particular, a importância do atributo merece atenção especial, à medida que cada consumidor a avalia de uma maneira diferente, de acordo com o significado que o atributo tem para si. Pesquisas indicam que a importância do atributo está diretamente ligada à atenção que o consumidor dá especificamente a uma característica do produto e que são vários os fatores que afetam tal importância. Um deles são as características do receptor capazes de influenciar a atenção, como necessidades, valores, conceito do eu, dentre outras. O segundo são as características da mensagem, que podem direcionar a atenção do comprador para um atributo específico e fazê-lo concentrar nele sua capacidade cognitiva. $O$ terceiro são fatores de oportunidade de resposta.

Uma vez explorados os elementos que influenciam o processo decisório do consumidor, o próximo passo é detalhar cada etapa percorrida por ele para tomar uma decisão de compra.

\subsection{O PROCESSO DE TOMADA DE DECISÃO}

Quando trata do processo de decisão de compra, Kotler (2000, p.198) pondera que o importante é se identificar quem é o responsável pela decisão de compra, os tipos de decisões e as etapas seguidas. Em uma decisão de compra, as pessoas envolvidas podem assumir alguns papéis diferentes ao longo do processo. Assim, quem sugere a idéia do que comprar é o influenciador; quem aconselha ou influencia a compra é o influenciador; quem decide o que, como e onde comprar é o decisor; o comprador é quem efetivamente realiza a compra; o usuário é quem consome ou usa o produto ou serviço.

Assael (apud Kotler, 2000, p.199) destaca quatro tipos de comportamento de compra, de acordo com o cruzamento de duas dimensões: a primeira é o nível de envolvimento do consumidor, e a segunda, o grau com que ele busca informações e avalia 
marcas alternativas. Dessa matriz, o autor depreende que:

- nas compras que exijam alto envolvimento do consumidor e ampla avaliação de marcas pressupõe-se um comportamento de compra complexo. Nesse caso, o processo de decisão consiste nos seguintes passos: o comprador desenvolve crenças sobre o produto, em seguida, atitudes e, por último, faz uma escolha refletida. Normalmente, esse é o caso do produto caro, com pouca freqüência de compra.

- nas compras em que haja alto envolvimento, mas poucas diferenças entre marcas, o comportamento de compra é dito com dissonância cognitiva reduzida, já que o alto envolvimento indica produto caro, com pouca freqüência de compra e envolvendo risco, mas a pequena diferença entre marcas pressupõe relativa rapidez na decisão em virtude de uma oportunidade de preço ou conveniência da compra. O processo aqui consiste primeiro da escolha rápida, depois da aquisição de crenças a respeito do produto e das marcas e, por fim, da incorporação de uma série de atitudes.

- nas compras em que haja baixo envolvimento do consumidor e poucas diferenças entre marcas, casos em que o produto é barato e a freqüência de compra é alta, não há criação de fidelidade à marca, mas a formação de um hábito. Trata-se do comportamento de compra dito habitual. Não há a formação da seqüência normal, crença, atitude e comportamento, pois o comprador não procura exaustivamente por informações nem avalia marcas. Recebe passivamente informações pela mídia, cria familiaridade com a marca e, após a compra, pode ou não avaliar a escolha, já que o envolvimento é baixo. O desenho do processo tem a seguinte seqüência: crença por aprendizagem passiva, comportamento de compra, seguido ou não de avaliação.

- na situação de diferenças significativas entre marcas e baixo envolvimento, tem-se o comportamento de compra em busca da variedade. É caracterizado pela seqüência crença, escolha sem avaliação e avaliação durante o consumo. Na próxima compra, o consumidor pode procurar por outras marcas mais para adquirir outras experiências do que por insatisfação com aquela marca.

O conhecimento dos estágios do processo de decisão de compra é fundamental para entendermos o que leva o consumidor a decidir ou não pelo produto. Para se investigar como se dá esse processo, é preciso saber do consumidor quando houve o primeiro contato com a categoria e as marcas consideradas, suas crenças naquele momento, seu nível de 
envolvimento com o produto, como fez a escolha da marca e qual foi a satisfação pós compra. Kotler (2000, p.200) sugere que o consumidor passa por cinco etapas em um processo de compra comum:

Reconhecimento do problema: marca o início do processo, quando o consumidor identifica uma necessidade, que é provocada por estímulos internos (necessidade básica da pessoa - fome, sede ou sexo - transformada em impulso no nível consciente) ou externos (exposição ao objeto de desejo gerando o estímulo).

Busca de informações: ocorre em dois níveis de interesse, sendo o primeiro denominado atenção elevada, mais moderado, havendo maior receptividade da pessoa pela informação sobre um produto. No segundo, ocorre uma busca ativa por informações e o conhecimento das fontes passa a ter especial interesse, pois influenciam o consumidor de maneiras diferentes. Podem ser fontes pessoais (família, amigos, vizinhos, conhecidos), comerciais, (propaganda, vendedores, representantes, embalagens), públicas (meios de comunicação de massa, organizações de classificação de consumo) e experimentais (manuseio, exame, uso do produto). É por meio da busca de informações que os consumidores tomam conhecimento das marcas concorrentes e seus atributos e partem para a seleção das melhores. Nesse processo de seleção, de um conjunto total de marcas disponíveis no mercado, eles só têm ciência de um subgrupo, o chamado conjunto de conscientização. Se a marca atender aos critérios iniciais de seleção, ela fará parte do conjunto para consideração. Com mais informações, os consumidores restringem mais suas opções e ficam com as marcas aceitáveis (conjunto de escolha), com base nas quais será feita a escolha.

Avaliação de alternativas: os consumidores analisam alternativas por meio de diversos processos de avaliação, todos orientados de forma cognitiva, no nível da consciência e com base na racionalidade. Nesses processos, eles seguem alguns passos: primeiro, eles estão à busca da satisfação de uma necessidade; segundo, procuram por benefícios trazidos pelo produto; terceiro, vêem cada produto como um conjunto de atributos que entreguem certos benefícios capazes de satisfazer as necessidades. Em geral, os consumidores passam a ter crenças a respeito da marca, em função de como a marca se posiciona para cada atributo; o conjunto de crenças é que compõe a imagem de marca e esta, em última análise, varia de acordo com as experiências dos consumidores e com a maneira como ela é filtrada pelos efeitos da atenção seletiva, da distorção seletiva e da retenção seletiva. Os consumidores tomam atitudes relacionadas a várias marcas, isto é, julgam e assumem preferências, por meio 
de um procedimento de avaliação de atributos baseado no peso atribuído a cada um deles e na crença do que cada marca representa para cada atributo.

Decisão de compra: uma vez estabelecido o conjunto de escolha das marcas, dois fatores podem interferir entre a intenção e a decisão de compra. Um é a atitude dos outros, que pode ser uma recomendação negativa ou positiva em relação à preferência do consumidor e a motivação do consumidor para acatar os desejos dos outros. Outro diz respeito aos fatores situacionais imprevistos, que podem alterar as intenções de compra. $\mathrm{O}$ que pode influenciar significativamente a intenção de compra do consumidor é o risco percebido, que varia de acordo com fatores como valores envolvidos, incerteza em relação aos atributos e nível de autoconfiança do consumidor. Para reduzir o risco, ele até evita tomar decisões, busca opiniões de amigos, ancora-se em marcas conhecidas e em garantias. Quando se define a intenção de compra, o consumidor pode passar por cinco estágios distintos de decisão: decisão por marca, por fornecedor, por quantidade, por ocasião (em que momento) e por forma de pagamento.

Comportamento pós-compra: também conhecido como avaliações de alternativa pós-consumo, após o uso do produto, o consumidor pode ficar satisfeito ou insatisfeito, o que é função da proximidade entre as expectativas do comprador e o desempenho percebido do produto. Se este ficar abaixo das expectativas, a sensação é de desapontamento; se ficar acima, satisfação; se ficar muito acima, encantamento. Esses sentimentos é que definirão se o cliente voltará ou não a comprar. As expectativas são formadas a partir das informações obtidas das mensagens recebidas pela mídia, pelos revendedores, pelos amigos e outras fontes e quanto maior a defasagem entre as expectativas e o desempenho, maior a dissonância. Vale ressaltar que o estilo pessoal pode influenciar o grau da defasagem, já que uns podem exagerá-la e outros minimizá-la.

Engel, Blackwell e Miniard (2000, p.97) sugerem um modelo parecido, oferecendo, no entanto, uma contribuição interessante ao modelo de Kotler (2000, p.202). Após a etapa de busca de informação, os autores entendem haver uma fase antes da avaliação das alternativas, designada como processamento de informação e que compreende as etapas a que se submete o consumidor na busca externa. Em primeiro lugar, há a exposição, em que informação e persuasão atingem o consumidor, os sentidos são ativados e o processamento preliminar começa; depois vem a atenção, que é a alocação de capacidade de processamento na informação que chega, muito em função da relevância da mensagem e conteúdo; a 
compreensão é a próxima etapa, em que ocorre a análise em relação às categorias de significado armazenadas na memória; a aceitação vem em seguida e diz respeito à passagem da mensagem pelo filtro de crenças e atitudes; por fim, vem a retenção, que é a manutenção da nova informação na memória.

Além disso, os referidos autores (2000, p.100) sugerem que, após a fase de compra, intercala-se uma etapa correspondente ao consumo, antes das avaliações de alternativa pósconsumo e, depois da fase de pós-compra, existe uma etapa de despojamento, que trata do destino dado ao produto após sua utilização.

Para um entendimento mais completo do processo decisório de compra, é recomendável que se detalhe cada uma das etapas apontadas, bem como aquelas não incluídas no modelo apresentado, conforme mencionado no parágrafo anterior. Engel, Blackwell e Miniard (2000) descrevem com riqueza cada um dos passos e ajudam a abordar o assunto de forma mais detalhada.

Segundo Engel, Blackwell e Miniard (2000, p.116), a presença do reconhecimento da necessidade não ativa automaticamente uma ação. A necessidade reconhecida deve ser suficientemente importante e os consumidores devem acreditar que uma solução para a necessidade esteja dentro de seus meios. Uma necessidade deve ser primeiro ativada antes que possa ser reconhecida e os fatores que influenciam a probabilidade de uma necessidade ser ativada são o tempo (que deteriora o estado real do consumidor até ele se tornar discrepante do estado desejado), a mudança de circunstâncias, a aquisição de produtos (que pode ativar a necessidade de produtos adicionais), o consumo de produtos (a necessidade é ativada devido à falta de produto), as diferenças individuais e as influências de marketing.

A busca, conforme os referidos autores (2000, p.119), é a ativação motivada de conhecimento armazenado na memória ou de aquisição de informação do ambiente. Pode ser interna ou externa. A busca interna depende grandemente da adequação ou qualidade do conhecimento existente e da habilidade para recuperar o conhecimento armazenado. $\mathrm{O}$ grau de satisfação com compras anteriores também determina a confiança na busca interna. A busca externa ocorre quando a busca interna se mostra inadequada e o consumidor pode decidir coletar informação adicional do ambiente. Dá-se a busca pré-compra quando há uma decisão de compra futura e a busca continuada ocorre quando a aquisição de informação se dá em uma base relativamente regular. 
A busca incorpora algumas dimensões importantes a se analisar em nosso estudo. Dentre elas, cita-se o grau, a direção e a seqüência. O grau representa a quantidade total da busca, por exemplo, o dimensionamento de quantas marcas são consideradas, quantas lojas são visitadas, quantos atributos são avaliados, quantas fontes de informação são usadas, quanto tempo é gasto na busca. A direção representa o conteúdo específico da busca, por exemplo, que marcas são consideradas, que lojas são visitadas, que atributos são ponderados, que fontes de informação são usadas. A seqüência representa a ordem na qual ocorrem as atividades de busca, como em que ordem as marcas são consideradas, em que ordem as lojas são visitadas, em que ordem a informação de atributo de produto é processada, em que ordem as fontes de informação são usadas.

Além das dimensões, os autores mencionados (2000, p.126) destacam quatro fatores que determinam a busca. O primeiro são os situacionais e dizem respeito à disponibilidade e quantidade de informação no mercado, formato da informação, pressões de tempo. O segundo são os de produto, que tratam do grau de diferenciação de produto, marca, preço, estabilidade de uma categoria de produto. Os de varejo são o terceiro e, dentre outros aspectos, refletem a distância entre os varejistas concorrentes, o que pode determinar o número de lojas visitadas na tomada de decisão. E os de consumidor são o último e dizem respeito ao seu conhecimento, envolvimento, crenças e atitudes e características demográficas.

Na etapa de processamento da informação, Engel, Blackwell e Miniard (2000, p.309) destacam a existência de cinco estágios, que praticamente refletem os conceitos de percepção abordados na seção 5.2. Trata-se da exposição, atenção, compreensão, aceitação e retenção. $\mathrm{O}$ primeiro se refere à oportunidade de que um ou mais dos sentidos seja ativado mediante a proximidade de um estímulo; dependendo da força desse estímulo, a ativação pode ser afetada por três níveis de limiar: inferior, que é a intensidade mínima de estímulo necessária para ocorrer uma sensação; terminal, que é o limite no qual aumentos na intensidade do estímulo não têm efeito na sensação; e diferencial, que é a menor mudança de intensidade de estímulo percebida pelo indivíduo. A atenção é a alocação da capacidade de processamento de um estímulo e é influenciada por alguns determinantes: os pessoais são a necessidade e motivação, as atitudes, o nível de adaptação ou hábito ao estímulo e a amplitude de atenção, que é o tempo máximo dedicado a um estímulo; os de estímulo de atenção são relacionados às características dos próprios estímulos como o tamanho, cor, intensidade, contraste, posição direcionalidade, movimento, isolamento, dentre outros. A compreensão é o terceiro estágio e trata do ponto no qual o significado é anexado ao estímulo; este significado 
depende de como o estímulo é categorizado, isto é, sua classificação conforme conceitos armazenados na memória e de qual o grau de elaboração, ou seja, a quantidade de integração entre a nova informação e o conhecimento existente. A compreensão ainda apresenta determinantes pessoais, como motivação, conhecimento e expectativa perceptual e determinantes de estímulo de compreensão, como as propriedades físicas do estímulo (cor, tamanho, nome de marca, embalagem), a lingüística, a ordem de aparecimento e o contexto. $\mathrm{O}$ quarto estágio é a aceitação e enfoca o efeito persuasivo do estímulo que pode ser refletido ao influenciar conhecimento, atitudes e o próprio comportamento; depende das respostas cognitivas e também das sensações resultantes, isto é, as respostas afetivas. O último estágio, o da retenção, envolve a transferência de informação para a memória de longo prazo.

$\mathrm{Na}$ avaliação de alternativas pré-compra, o consumidor passa por dimensões ou atributos particulares usados no julgamento de escolha. Essas dimensões vêm em várias formas: podem ser fatores como segurança, confiabilidade, preço, nome da marca, país de origem, garantia; podem ser fatores de caráter hedonista, como os sentimentos advindos da posse (prestígio e status). Os critérios de avaliação apresentam saliências, que são o potencial de influência que cada dimensão pode exercer durante o processo de comparação. Daí, surgem os atributos determinantes, que são aqueles nos quais as alternativas diferem em desempenho.

Os critérios de avaliação apresentam alguns determinantes. A influência situacional é um deles e se refere a fatores como pressão do tempo, pressão social e podem ter influência na saliência do critério de avaliação. A similaridade de alternativas de escolha é outro e compreende as decisões que envolvem alternativas não comparáveis, podendo exigir que o consumidor use mais critérios de avaliação abstratos durante a avaliação da alternativa. Ainda pode ser citada a motivação, que pode ser utilitária (o que levará ao exame do preço e das características do produto) e hedonista (o que leva à consideração de sentimentos que surjam com a posse e o uso do produto); o envolvimento com a decisão, que influencia o número de critérios de avaliação usados na avaliação de alternativa; e o conhecimento, que influencia na informação das dimensões úteis que o consumidor tem para a comparação das alternativas de escolha armazenadas na memória.

As alternativas dentre as quais a escolha deverá ser feita define o conjunto de consideração ou conjunto de evocação. Quando o consumidor tem conhecimento prévio, o conjunto de consideração pode ser formado por busca interna. Quando não há esse 
conhecimento, fatores externos como o ambiente de varejo podem afetar mais o conjunto de consideração.

Na compra, os referidos autores (2000, p.152) comentam que a consumação ou não de uma compra freqüentemente sofre interferência de alguns fatores: o primeiro deles diz respeito a mudanças de motivações, em que as necessidades existentes são atendidas de outras maneiras ou surgem novas necessidades mais prementes; o segundo refere-se a mudanças de circunstâncias, como o surgimento de condições econômicas adversas; o terceiro trata do aparecimento de uma nova informação, desconsiderando a avaliação de alternativa anterior; o quarto contempla a situação em que as alternativas escolhidas não estão mais disponíveis.

Também exercem influência na compra o momento oportuno para sua realização e o nível de planejamento usado para a escolha da alternativa. Uma compra totalmente planejada, em que o produto e a marca são escolhidos previamente, pode ocorrer com a presença de alto ou baixo envolvimento e é favorecida, principalmente, pelo conhecimento que o consumidor tem do arranjo da loja e pela pressão de tempo que limita a procura e exige a tomada de decisão no local. Na compra parcialmente planejada, o produto já está definido, mas a marca é decidida no ponto de venda; quando o envolvimento é alto, a compra torna-se importante forma de buscar informação; quando é baixo, a escolha se dá pela marca mais conhecida e aceitável. No caso da compra não-planejada, ambos, produto e marca, são escolhidos na loja em duas situações distintas: a primeira, em que a necessidade de compra é disparada pela exposição do produto, e a segunda, em que o consumidor experimenta um desejo repentino de realizar uma compra naquele ato, ou seja, por impulso.

Continuando a abordar os agentes que afetam a decisão de compra, os autores salientam a existência de um forte elemento de consumação das intenções de compra, com importantes reflexos para o marketing. Trata-se dos fatores situacionais, que podem estar na esfera de influência de marketing, como a exposição e a promoção do produto, os preços reduzidos, a atmosfera da loja ou fora dela, como o clima e o desemprego. Os motivos de escolha da loja como local de compra também são elencados e podem ser de dois tipos: pessoais - em que o consumidor considera a compra uma oportunidade para desviar da rotina, aprender sobre novas tendências, realizar uma atividade física diferente ativar estímulos sensoriais, buscar autogratificação - e sociais, em que ele vivencia experiências fora de casa, comunica-se com pessoas que têm interesses similares, pode adquirir status e autoridade, dentre outros. 
Após a compra, é natural que ocorra o consumo do produto ou serviço. Engel, Blackwell e Miniard (2000, p.172) argumentam que o consumidor tem várias opções para decidir de que forma vai consumir, o que inclui usar o produto na primeira oportunidade, armazená-lo por um curto prazo para aproveitar oportunidade posterior ou por um longo prazo, sem uso específico. Outra opção é não consumar o uso, em função de algum arrependimento motivado pela dúvida pós-decisão (dissonância cognitiva), o que pode ser ativado por circunstâncias como a irreversibilidade da ação, existência de outras alternativas preteridas com atributos desejáveis, e a superação do limiar de tensão causado pela dissonância.

Uma vez comprado e consumido o produto, o processo de avaliação não é interrompido. Os autores (2000, p.177) reforçam esse comportamento, principalmente nos casos de alto envolvimento e destacam que a avaliação de alternativa pós-consumo pode assumir uma das duas formas seguintes: satisfação ou insatisfação do cliente. A satisfação ocorre quando a alternativa escolhida pelo menos atende ou excede as expectativas. Oliver (1980 apud Engel; Blackwell; Miniard, 2000, p.178) postula, em seu modelo de desconfirmação de expectativa, que satisfação ou insatisfação resulta da comparação de expectativas com resultados reais. Tais expectativas podem recair em três diferentes categorias: a de desempenho equivalente, em que há um julgamento do desempenho que deve ser proporcionado pelo produto, considerando custos e esforços incorridos na compra e uso; a de desempenho ideal, que é o nível ótimo esperado de desempenho; desempenho esperado, que é o nível provável de desempenho. Por sua vez, o julgamento satisfação / insatisfação pode assumir três formas diferentes: a de desconfirmação positiva, em que o desempenho é melhor que o esperado; a de confirmação simples, em que o desempenho empata com as expectativas; e a de desconfirmação negativa, em que o desempenho é pior que o esperado.

A insatisfação, em forma de resposta do consumidor, pode assumir as seguintes configurações, segundo os autores (2000, p.179): respostas verbais, visando à reparação do vendedor; respostas particulares, desenvolvendo uma comunicação boca-a-boca negativa; e repostas de terceiros, objetivando processar legalmente o vendedor. Há evidências de que o esforço para retificar problemas aumenta a certeza do consumidor de que a empresa se importa realmente com ele.

Por fim, os autores (2000, p.184) tratam do despojamento ou descarte, que sempre existiu após o uso do produto, mas que só mereceu atenção recentemente da estratégia e pesquisa de marketing, principalmente pelas sérias preocupações ambientais que surgiram nas 
últimas décadas. Essa etapa pode ser dividida em três categorias: descarte direto, reciclagem e remarketing. A primeira compreende a interrupção do uso do produto e seu despojamento, que pode envolver algum tipo de ritual, dependendo dos laços psicológicos estabelecidos do usuário para com o item; a segunda é uma forma adotada pelos governos que passaram a demonstrar apreço pelas questões ambientais; e a terceira reflete o crescente movimento do mercado de produtos usados dada a forte demanda existente por esse tipo de produto.

\subsubsection{Tipos de Processos Decisórios}

Engel, Blackwell e Miniard (2000, p.101) ressalvam que nem sempre os processos decisórios seguem exatamente as etapas da forma como foi descrita. Em função da complexidade desse processo, mais ou menos tempo e energia são despendidos, o que acaba por indicar o tipo de solução de problema adotado.

Os autores explicam que, caso se pense em uma escala contínua de complexidade do processo decisório, em um extremo se tem a solução de problema ampliada (SPA), em que as decisões são mais difíceis, há maior rigor envolvido e os custos e riscos de uma decisão errada são altos. Nos casos de SPA, possivelmente todos os estágios do processo decisório são percorridos, embora não necessariamente na mesma ordem. "É provável que muitas alternativas sejam avaliadas e uma ampla variedade de fontes de informação seja consultada. Além disso, a decisão de como e onde fazer a compra também exige busca e avaliação adicionais" (ENGEL; BLACKWELL; MINIARD, 2000, p.103).

No outro extremo, continuam, há a solução de problema limitada (SPL), que representa um grau mais baixo de complexidade. Os processos situados no meio da escala são considerados como solução de problema de médio alcance.

Segundo os autores, quando o consumidor está tomando a decisão de compra pela primeira vez e o processo é por SPA, estabelece-se, freqüentemente, um padrão de compra caracterizado pela lealdade à marca, com passagem provável por todos os estágios decisórios e a reflexão e avaliação antes da compra, dado o rigor que se impõe nas escolhas. Se o processo for por SPL, na maioria da vezes, por falta de tempo, recursos ou motivação para ocupar-se de SPA, o consumidor simplifica o processo decisório e reduz o número de fontes de informação, alternativas e critérios de avaliação. Comprar a marca conhecida ou a mais barata passa a ser a regra. Em SPL, a participação de mercado do produto é normalmente conquistada por meio de esforço de comunicação em mídia e ações de ponto de venda. 
Quando não é a primeira vez que o consumidor exerce a compra, isto é, caso de compras repetidas, há duas possibilidades: solução de problema repetida ou tomada de decisão habitual. A primeira situação ocorre, em geral, quando há insatisfação com a alternativa comprada anteriormente, o que pode levar a uma troca de marca, quando se esgota o estoque do produto almejado ou quando há alguma mudança nas circunstâncias do ponto de venda. A segunda situação diz respeito a compras feitas com base em hábitos desenvolvidos pelo consumidor, principalmente para enfrentar as pressões diárias, gerando um comportamento que pode assumir diferentes formas, devido ao processo decisório usado na compra inicial: lealdade à marca ou empresa; ou inércia. A primeira forma é o desejo de todos fornecedores de produtos ou serviços, pois a lealdade é altamente resistente à mudança; na segunda, a lealdade é limitada e qualquer ação de marketing, como redução de preços ou outra oferta, pode direcionar o consumidor para outra marca.

Algumas categorias especiais de compra são citadas por Engel, Blackwell e Miniard (2000, p. 105), por não se encaixarem exatamente na escala de solução de problemas apresentada. Trata-se da compra por impulso e da busca de variedade. A compra por impulso é dita como uma forma menos complexa de SPL, mas diferencia-se dela pela presença de fatores específicos como: desejo súbito de ação, acompanhado do sentimento de urgência; conflito psicológico que necessita de ação imediata para ser resolvido; avaliação objetiva mínima, em que as considerações emocionais são dominantes; e desconsideração das conseqüências. A busca de variedades, isto é, eventuais trocas de marca, ocorre quando há muitas alternativas similares.

Conforme Engel, Blacwell e Miniard (2000, p.106), o tipo de extensão da solução de problema é influenciado por algumas condições particulares. No caso da SPA, três fatores importantes se fazem presentes: há um alto grau de envolvimento do comprador; as alternativas são diferenciadas de maneiras variadas e há tempo suficiente para a decisão.

Envolvimento, conforme Antil (apud EngEL; Blackwell; Miniard, 2000, p.106), é "o grau de importância pessoal percebida ou interesse evocado por um estímulo (ou estímulos) dentro de uma situação específica" e seus determinantes principais são: fatores pessoais, fatores situacionais e fatores de produto. No tocante aos fatores pessoais, destaca-se a necessidade e o impulso, sem os quais não há envolvimento. Quanto aos fatores situacionais, são aqueles que fazem com que o envolvimento mude com o tempo, como no caso em que é verificada sua diminuição ao ser resolvido o problema da compra, aumentada 
ao ser alterada a aplicação do produto ou quando são exercidas pressões sociais. Quanto aos fatores de produto, o envolvimento é maior quanto mais intenso o risco percebido na compra e no uso do produto.

Com relação à diferenciação de alternativas e a disponibilidade de tempo, é natural que, em SPA, isso aconteça, pois o consumidor, dado seu envolvimento, conhece mais os detalhes da escolha, no primeiro caso, e dedica mais tempo para a avaliação de alternativas, no segundo.

Os autores prosseguem avaliando os resultados do alto envolvimento. Normalmente, a SPA é iniciada por avaliação de alternativa pré-compra, em que o consumidor busca toda informação relevante e a processa. Os consumidores mais envolvidos sofrem mais influência dos apelos usados nas ferramentas de comunicação, como a propaganda e a promoção de vendas e têm maior probabilidade de perceber diferenças nos atributos oferecidos por diversas marcas e produtos, o que gera lealdade à marca como resultado comum.

Cabe, nesse ponto, um comentário, chamando atenção para o fator de produto, um dos determinantes do grau de envolvimento. O preservativo é o tipo de produto cuja percepção de risco é alta, pois estão envolvidos dois aspectos sensíveis à segurança associada ao seu uso: a prevenção contra doenças sexualmente transmissíveis e Aids e contra a gravidez. Tendo isso em vista, o enredo teórico traçado nesta seção, sugere que a decisão de compra do produto em análise é tomada por SPA, em que o grau de envolvimento é um dos determinantes mais fortes. No caso, há grande probabilidade de o consumidor seguir todas as etapas do processo decisório, mas a avaliação pós-consumo desempenha um papel de destaque. Provavelmente seja ela a responsável pela lealdade à marca, umas das conseqüências mais evidentes da SPA e um dos atributos mais valorizados para o caso dos preservativos, como poderá ser visto nos resultados das pesquisas.

Uma vez abordada a vertente genérica da teoria do comportamento do consumidor, cabe agora trazer à tona estudos específicos sobre o comportamento de uso e de compra dos preservativos. 
$\mathrm{O}$ vírus da Aids tem sido responsável pela contaminação de milhares de pessoas, nos últimos anos. Inicialmente associada a homossexuais e a usuários de drogas injetáveis, hoje a Aids é vista também como uma ameaça aos heterossexuais.

Hill e Stephens (1990) relatam que o marketing, ao longo dos anos, tem oferecido respostas a esse cenário, criando uma vasta gama de produtos e serviços para ajudar pessoas com Aids a lidar com a situação. O produto que mais tem recebido atenção desde a descoberta do vírus foi o preservativo, sendo oferecido no mercado para os que se preocupam com a doença como meio de reduzir as possibilidades de infecção durante a relação sexual.

Conforme os referidos autores, o preservativo vem passando por mudanças consideráveis em sua estratégia de promoção por meio de novos apelos e novas mídias.

Agnew (1987, apud HiLl; STEPHENS, 1990) reforçam que a propaganda de preservativos, nesse cenário dinâmico, vem mudando seu foco da ênfase na contracepção para o sexo seguro (muitas vezes, fazendo uso de apelos baseados no medo ou na ansiedade).

Mota (1998) introduz um outro importante elemento na discussão do preservativo, tratando a experiência erótica masculina como um provedor de fundamentos para a elaboração de estratégias de prevenção da doença. Sob essa ótica, pondera que o preservativo está sob o controle do homem e não da mulher e que a prevenção se articula, portanto, com aspectos associados ao gênero. Comentando sobre o debate preventivo, o que inclui o uso do preservativo, o autor acrescenta o aspecto social e cultural:

\footnotetext{
...o debate preventivo deverá lidar com os aspectos do gênero, menos como uma barreira à elaboração de novos métodos e mais como uma luz que venha colocar o tema da erotização das práticas sexuais seguras para o HIV / Aids, de maneira explícita, em campanhas públicas que trabalhem a questão dos papéis sociais legados a homens e mulheres, tendo como base suas implicações políticas dentro de uma amplo contexto educacional. Percebe-se que as mudanças em tempos de Aids abrangem fatos mais amplos como a cultura sexual, e menos específicos, como é o caso das relações sexuais em si (MOTA, 1998).
}

Relacionando-se o consumo do preservativo com a Aids, é apropriado, neste ponto, inserir a observação de Hirschman e Holbrook (1982) de que o comportamento do consumidor motivado por desejos afetivos é denominado "consumo hedônico" e envolve 
elementos que se relacionam ao multisensorial, fantasias e aspectos emocionais do comportamento.

Havlena e Holbrook (1986) argumentam que, no consumo hedônico, a busca por excitação emocional é um importante motivador quando o indivíduo escolhe um produto para consumo.

Hill e Gardner (1986 apud HiLl; StePhens, 1990), por sua vez, adicionam que os consumidores, inconscientemente ou não, acabam por usar o processo de compra para lidar com seus estados afetivos. Dessas noções, Hill (1989) depreende que a motivação do consumidor na escolha de um produto pode ser um desejo por um estado emocional alterado. Em outras palavras, o consumidor pode se valer da experiência de consumo para atenuar um estado de infelicidade ou de sensações desagradáveis.

Esse pode ser claramente o caso do preservativo. Hill (1988) descobriu que a partir do advento da Aids, o consumidor passou a expressar uma reação emocional ao produto caracterizada pela ansiedade. As pessoas que expressaram maior ansiedade a respeito da Aids apresentaram atitudes mais positivas em relação aos anúncios de preservativos, da mesma forma que as pessoas de grupos de risco, com muitos parceiros sexuais, em relação às marcas de preservativos. Esse fato é reforçado pela constatação da realidade brasileira, feita por Mota (1998, p.9):

Percebemos que os mais identificados, no início, com a transmissão da epidemia (os homossexuais), são justamente os que apresentam melhor percepção do risco hoje. Ao contrário, os sujeitos inscritos dentro de um leque de possibilidades "morais-sexuais" (os chamados heterossexuais masculinos) são os que demonstram maior inconsistência na redução do risco para o HIV / Aids, o que não significa afirmar que a síndrome não tenha tido algum impacto em suas vidas.

Essas discussões trazem à tona um dos aspectos mais importantes da experiência de consumo: o uso do produto.

No contexto nacional, como pode ser visto com mais detalhes nos resultados da pesquisa MS/IBOPE 2003, mostrados na seção 9, o brasileiro sexualmente ativo ainda mostra resistência. O número dos indivíduos sexualmente ativos que usaram de forma consistente o produto, entre os anos de 1999 e 2002, experimentou redução significativa. Dentre os grupos que contribuíram para esse retrocesso, está o de brasileiros com relação estável e exclusiva, 
que registrou aumento representativo na não utilização do produto; entretanto, foi verificado o aumento do uso dentre os que mantêm relações com parceiros eventuais. Esse fato sugere que as razões para não se usar o preservativo estão ligadas à confiança que se deposita no parceiro.

Dados da referida pesquisa atestam outro fato marcante: na comparação entre os dois períodos, as mulheres com relações estáveis usaram menos consistentemente o dispositivo do que os homens, como pode ser melhor observado também na seção 9. Esse fato pode ser igualmente constatado na população com menor índice de instrução, até o ensino fundamental. A população da faixa etária entre de 14 e 25 anos é o grupo que mais usa preservativo na primeira relação sexual $(54,6 \%)$ e o que usa mais consistentemente $(28,3 \%)$.

A questão da relação entre confiança no parceiro e uso do preservativo ainda traz contribuições a este estudo. Em pesquisa conduzida para examinar reações potenciais do consumidor ao conflito potencial entre a necessidade de proteção contra a Aids e a confiança entre parceiros sexuais de primeira vez, Hill e Stephens (1990) chegaram a importantes conclusões. A sugestão do uso de preservativo por um dos parceiros pode levantar a suspeita de que ele ou o outro possam ser portadores de alguma doença sexualmente transmissível. Para a pessoa que sugere o uso, o resultado é uma mistura de respostas físicas (reações negativas incluindo constrangimento, dificuldade, perda do desejo sexual e medo; reações positivas incluindo sensação de segurança ou alívio, aumento do bom humor e excitação sexual) e respostas a seu respeito (reações negativas incluindo incerteza, desaprovação e obscenidade; reações positivas incluindo responsabilidade, inteligência e confiança). No entanto, no cenário em que a sugestão é feita pelo parceiro, muitas das reações negativas passam a ser minimizadas. A maioria dos indivíduos responderam com a sensação de responsabilidade compartilhada e a favor do parceiro que sugeriu (efeito mais aparente com mulheres e usuários freqüentes).

Os autores da mencionada pesquisa ainda apontam implicações dos resultados para o marketing, sugerindo que a percepção da necessidade do uso do preservativo para prevenir DSTs e Aids é elevada, mas as taxas de uso são baixas por causa das dificuldades interpessoais para sugerir o uso ao parceiro. Uma discussão aberta sobre o assunto, fugindo dos apelos baseados no medo e caminhando para anúncios com conteúdos realísticos e francos, poderia ser uma alternativa de sucesso para os profissionais de marketing. Além da comunicação, os autores levantam a oportunidade de novos esforços promocionais sobre o 
produto, que enfoquem os propósitos de eficácia e sensibilidade, já que apontam a interrupção do namoro e a redução da sensibilidade como a maior desvantagem do uso do preservativo.

Mudanças de comportamento e fatores que podem originá-las são amplamente estudados nos Estados Unidos. Para Guttmacher et al (1997), a infecção por HIV é uma das maiores ameaças à saúde dos adolescentes do país, considerando que a grande maioria dos alunos do ensino médio é sexualmente ativa, não usam preservativo consistentemente e não conhecem sua situação sorológica, nem a do parceiro. Dessa forma, em pesquisa implementada pelos autores para se descobrir o impacto do programa de disponibilização de preservativos nas escolas públicas de Nova Iorque e Chicago, os resultados foram favoráveis a esse tipo de ação. 
Em termos de hábito de compra, o preservativo pode ser considerado um bem de conveniência. Segundo Kotler (2000, p.418), “os bens de conveniência são aqueles que o consumidor compra com freqüência, imediatamente e com um mínimo de esforço". Podem ser básicos, se comprados regularmente; bens de impulso, se comprados sem qualquer planejamento ou esforço de busca; bens de emergência, se comprados quando há uma necessidade premente. O preservativo pode ser classificado na primeira e na terceira categoria.

Quanto à durabilidade, pode se enquadrar na classificação dos bens não-duráveis, que Kotler (2000, p.418) conceitua como "bens tangíveis normalmente consumidos ou usados uma ou poucas vezes [...]”. Como o consumo é rápido e, portanto, a freqüência de compra é alta, a estratégia por trás desse tipo de produto passa pela distribuição para muitos pontos de venda, baixa margem de lucratividade, grande esforço de comunicação para fixação de imagem e indução à experimentação e preferência do consumidor.

Em geral, o fabricante disponibiliza no ponto de venda, para o consumidor, um sortimento ou mix de produtos, que Kotler (2000, p.420) caracteriza como um conjunto de itens colocados à venda, possuindo abrangência, extensão, profundidade e consistência. A abrangência diz respeito ao número de linhas de produtos fabricados pela empresa; a extensão refere-se ao número total de itens no mix; a profundidade é o número de opções de itens em uma linha específica; a consistência do mix está relacionada à proximidade com que várias linhas estão ligadas quanto ao uso final, processo de produção, canais de distribuição ou outro critério.

Historicamente, a linha de preservativos normalmente comercializada pelos fabricantes nunca apresentou profundidade. Sempre foi composta de um tipo lubrificado e outro não, com uma variante de quantidade por embalagem (com três e com seis unidades). Mais recentemente, pode-se observar uma ampliação da linha, com a incorporação de mais variantes, como poderá ser observado na sessão 9.2.

\subsection{A MARCA}

A marca é talvez um dos mais importantes ativos de uma empresa e sua gestão pode ser apontada como o principal problema na estratégia de produto, exigindo dos fabricantes um 
trabalho constante de manutenção, proteção e melhoria. Kotler (2000, p.426) conceitua marca como "um nome, termo, símbolo, desenho - ou uma combinação desses elementos - que deve identificar os bens ou serviços de uma empresa ou grupo de empresas e diferenciá-los dos da concorrência". Mais que um símbolo, a marca pode trazer significados muito importantes, como os atributos associados, os benefícios oferecidos, os valores e cultura da empresa, uma personalidade e o tipo de usuário que melhor se ajuste ao produto.

Para Kotler (2000, p.427), uma marca se diferencia da outra também por seu valor de mercado e por seu poder.

Aaker (1998, p.14) aponta que o valor representado pelo nome de uma marca é um ativo intangível da empresa e, em muitos casos, um dos mais importantes, representando a base da vantagem competitiva e de ganhos futuros. O que contribui para o aumento ou a redução desse valor é o que chama de brand equity ou patrimônio de marca, definido como "um conjunto de ativos e passivos ligados a uma marca, seu nome e seu símbolo, que se somam e se subtraem do valor proporcionado por um produto ou serviço para uma empresa e/ou para os consumidores dela". De forma prática, esses ativos e passivos podem ser agrupados nas seguintes categorias: lealdade à marca, conhecimento do nome, qualidade percebida, associações da marca em acréscimo à qualidade percebida e outros ativos do proprietário da marca (patentes, relações com os canais de distribuição etc.).

A lealdade à marca é, freqüentemente, o cerne do patrimônio de marca, à medida que a conquista de novos consumidores é desgastante e cara, quando comparada à manutenção dos clientes existentes. Ter uma base de clientes leais pode representar uma menor vulnerabilidade aos ataques dos competidores e ser um forte indicador de vendas futuras. Aaker (1998, p.41) destaca cinco diferentes níveis de lealdade do consumidor, conforme pode ser observado na pirâmide de fidelidade representada na figura 4. A base dela é ocupada pelos consumidores não-leais, para quem o nome da marca desempenha papel irrelevante na decisão de compra - são os chamados compradores mutáveis ou por preço. Acima da base, encontram-se os consumidores satisfeitos com o produto, ou sem insatisfações que motivem quaisquer mudanças - são os compradores habituais. O terceiro nível é formado também pelos satisfeitos, mas com medo dos custos de mudança, de tempo, de dinheiro ou desempenho do produto associados - são os compradores leais, mas suscetíveis a mudanças. O próximo nível contempla os que gostam realmente da marca sem uma razão específica, mas que provavelmente esteja ligada a uma associação com experiências vivenciadas, uma alta 
qualidade percebida ou algum símbolo - são os chamados amigos da marca em função da ligação emocional existente. $\mathrm{O}$ topo da pirâmide é ocupado pelos consumidores comprometidos, aqueles para quem a marca representa uma importância funcional ou expressa sua própria imagem.

Figura 4 - A pirâmide da lealdade

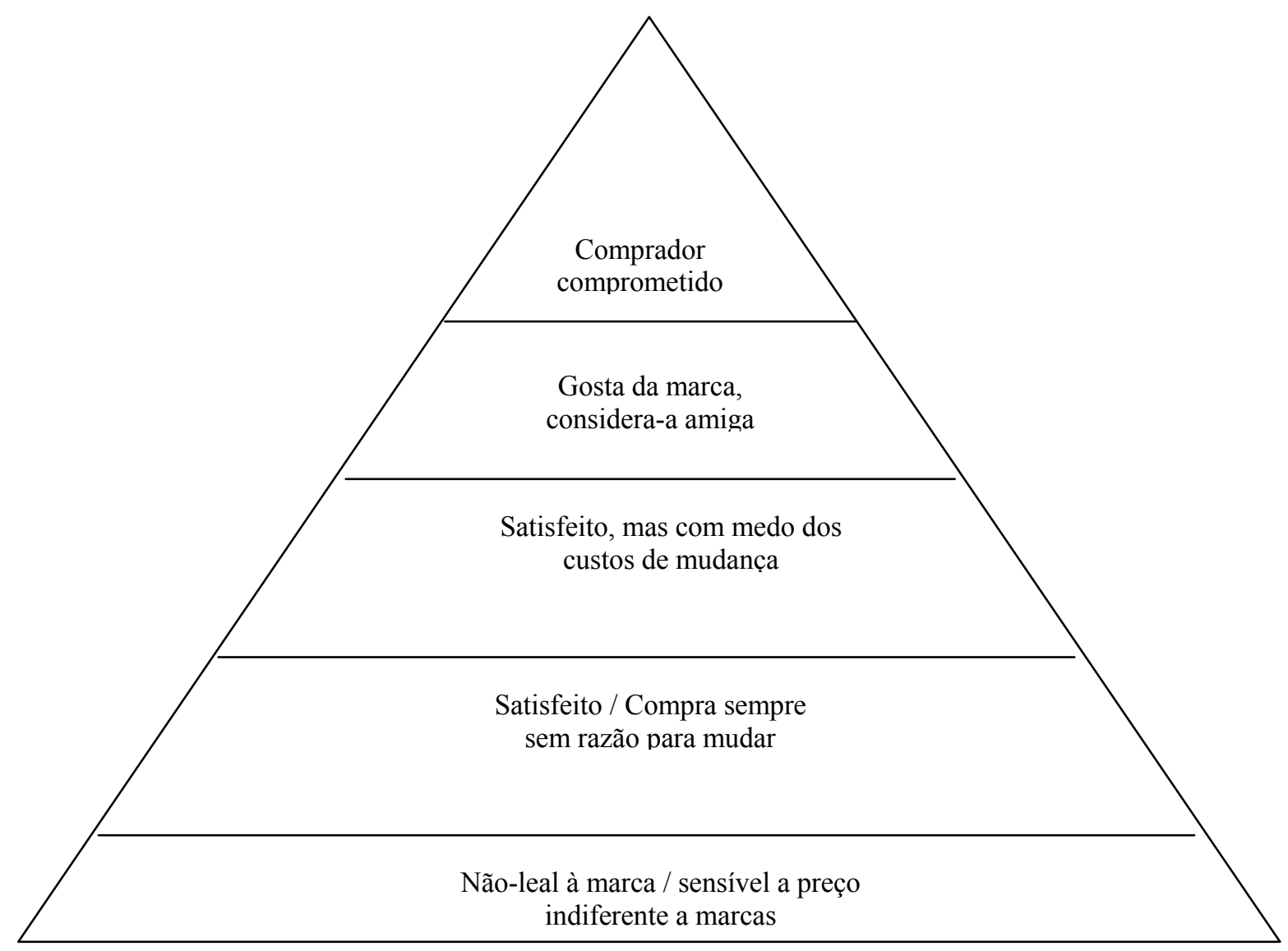

Fonte: AAKER, D. A. Marcas: Brand Equity - Gerenciando o Valor da Marca. São Paulo: Negócio, 1998, p.41.

Aaker (1998, p.48) ainda destaca diversas maneiras pelas quais a lealdade à marca proporciona valor. A primeira diz respeito aos custos de marketing reduzidos, já que é muito mais barato reter clientes existentes do que conquistar novos. A segunda refere-se à alavancagem comercial, propiciada à medida que os canais de distribuição dão preferência a marcas mais procuradas, com maior probabilidade de giro do produto. A terceira é a atração de novos consumidores, mais provável de ocorrer quando já existem clientes satisfeitos que endossam a marca e servem como grupos de referência. A última forma é o tempo que a lealdade à marca proporciona para a empresa reagir ao ataque da concorrência. 
O conhecimento da marca e de seus símbolos é uma importante condição para que o consumidor a considere familiar e, em conseqüência, freqüentemente a selecione diante de outras alternativas menos conhecidas. Aaker (1998, p.65) afirma que há um intervalo contínuo de sentimentos envolvendo o conhecimento da marca, que vai desde aquele que a desconhece até o que a considera única em uma determinada classe de produtos. O intervalo pode ser dividido em três níveis distintos:

- o primeiro é o de reconhecimento da marca, em que o consumidor, a partir do estímulo de uma lista, consegue identificá-la, por já ter ouvido falar dela antes;

- o segundo é o da lembrança da marca, em que o consumidor se recorda do nome, sem o estímulo da lista de nomes do nível anterior; representa uma posição mais forte da marca.

- o último é o Top of Mind, posição privilegiada da marca em que o consumidor a reconhece na frente de todas outras, sem estímulos.

O referido autor (1998, p.66) pondera que o conhecimento da marca cria valor de maneiras diferentes. Na primeira delas, considera-o como uma âncora a que outras associações possam estar ligadas, isto é, o conhecimento da marca permite associá-la mais facilmente a diversos outros atributos. A segunda dá-se por meio da familiaridade com a marca, o que freqüentemente dirige a decisão de compra. A terceira diz respeito à presença, comprometimento e substância que uma marca bem conhecida e divulgada transmite ao seu consumidor. A última maneira está relacionada ao fato de que, no processo de compra, o consumidor primeiro seleciona um grupo de marcas a considerar e o conhecimento da marca é fundamental para que ela faça parte dessa seleção.

A qualidade percebida pode ser conceituada como "o conhecimento que o consumidor tem da qualidade geral ou superioridade de um produto ou serviço pretendido, em relação a alternativas" (AAKER, 1998, p.88). Não necessariamente está baseada no conhecimento de especificações do produto e é forte fator de influência na decisão de compra e na lealdade à marca. Pode gerar valor à medida que: em muitos casos, torna-se a razão central de compra; é elemento de diferenciação e posicionamento do produto; pode sustentar com facilidade estratégias de preço premium e de extensão de marca; e pode influenciar positivamente o interesse de compra dos canais de distribuição.

Por fim, as associações da marca, isto é, ligações com personagens, contexto de uso, estilos de vida, personalidades podem ser a base para a extensão de uma marca ou a defesa necessária para um ataque da concorrência focado em um determinado atributo. "O valor 
resultante de uma marca é freqüentemente o seu conjunto de associações, o seu significado para as pessoas. As associações representam as bases para as decisões de compra e para a lealdade à marca" (AAKER, 1998, p.116).

Essas associações criam valor para a empresa e seus clientes de várias formas. Ajudam a resumir fatos e especificações sobre a marca, facilitando o processamento por parte do consumidor e a ação de comunicação da empresa; proporcionam bases consideráveis para a estratégia de diferenciação; são fundamentais para o estabelecimento de uma base para decisões de compra e lealdade à marca, influenciando a decisão de compra pela credibilidade e confiança da marca; permitem a criação de atitudes e sentimentos positivos, durante a experiência de uso; e podem proporcionar bases sólidas para uma extensão, por meio da ligação entre o nome da marca e novos produtos.

\subsection{ATRIBUTOS DE PRODUTO}

Além da marca, o marketing se preocupa em definir as características do produto em si que, em última análise, contribuem para o posicionamento dela. São os chamados atributos de produto, dentre os quais os principais são destacados a seguir:

\subsubsection{Nível de Qualidade}

Na tomada de decisão de compra, o nível de qualidade do produto ou serviço sempre é um quesito de elevada consideração pelo consumidor. Churchill e Peter (2003, p.272) argumentam que os clientes buscam produtos que executem devidamente as funções a que se destinam, embora haja aqueles que aceitem uma qualidade menor por um preço mais baixo ou por um uso mais fácil do produto. De maneira geral, uma dimensão da qualidade percebida para esse produto é a forma, e a forma é uma tradução do design e da embalagem.

Mas os clientes normalmente se guiam por critérios para determinar suas percepções de qualidade, sendo oito os mais gerais apontados pelo referido autor: desempenho (como o produto se sai na função); características (se são exclusivas desejáveis); confiabilidade (se o produto parece funcionar bem e não quebrar em um período curto de tempo); conformidade (se há adequação em relação a padrões estabelecidos, como segurança); durabilidade (quanto tempo deve durar o produto antes de se desgastar e ser substituído); serviços (velocidade com que os eventuais problemas com o produto são resolvidos); estética (quanto o produto é atraente para os sentidos humanos); e avaliação geral (considerando as características físicas, o fabricante, a imagem de marca, embalagem e preço). 
Um forte indicador desses critérios é a existência de garantia para o produto. "Garantia é a declaração do produtor do que ele fará para compensar o comprador se o produto tiver algum defeito ou não funcionar adequadamente" (CHURCHILL; PETER, 2003, p.273).

\subsubsection{Segurança do Produto}

Particularmente no caso de preservativos, o item segurança merece especial atenção, à medida que está relacionado à prevenção de doenças sexualmente transmissíveis e à contracepção. É natural que os consumidores busquem adquirir produtos que lhes ofereçam, dentre todos os benefícios, segurança durante o uso. Churchill e Peter (2003, p.274) defendem que a segurança está relacionada à ética, à medida que os clientes não devem ser prejudicados pelo uso do produto; e à prática, pois experiências negativas proporcionadas pela insegurança certamente representam barreiras para compras futuras.

\subsubsection{Embalagem}

A embalagem é outro aspecto relevante no estudo em questão. Kotler (2000, p.440) define embalagem como "o conjunto de atividades de projeto e produção do recipiente ou envoltório de um produto". Como instrumento de marketing, a embalagem pode agregar valor de conveniência e promocional, à medida que contribui para o reconhecimento da marca e da empresa por trás do produto, representa oportunidade de inovação, confere a possibilidade de melhor aparência e confiabilidade e facilita a compra pela forma do auto-serviço. Além desses aspectos, a própria função de proteção e conservação do produto é relevante. Especialmente no caso do preservativo, dada a exigência de qualidade e confiabilidade pelo consumidor, esse é um atributo de relevância considerável.

\subsubsection{Rotulagem}

A rotulagem também está presente nos produtos, seja por meio de uma etiqueta presa ou colada ao produto seja como parte da embalagem. Sua função é identificar o produto ou a marca, descrever o produto, sua constituição, modo de uso e promovê-lo. Recentemente, ações consumeristas tornaram algumas informações na embalagem obrigatórias por lei, como data de validade do produto, contato com serviços de pós-venda, dentre outras.

Peter e Churchill (2003, p.277) acrescentam que as informações nos rótulos são importantes também para os revendedores, que contam com a impressão do código de barras para facilitar sua operação. Esse código identifica diversas características do produto como o número do lote, seu tamanho, o peso e é usado para apontar o preço da mercadoria no scanner do caixa. 
Em alguns casos, como no do preservativo, as informações do rótulo ficam incorporadas na embalagem e o rótulo propriamente dito não existe, dadas as dimensões do produto e a falta de espaço para sua fixação.

\subsubsection{Preço}

Segundo Kotler (2000, p.476), o preço é o único elemento do marketing mix que produz receita e um dos mais flexíveis, pois pode ser alterado com rapidez, em comparação com os outros. Por outro lado, o maior problema das empresas é a concorrência de preços e, assim mesmo, muitas não sabem como lidar com essa variável.

É importante que a empresa posicione seu produto em termos de qualidade e preço, já que é muito provável uma competição entre segmentos formados levando em conta esse binômio. O referido autor (2000, p.477) arrola nove estratégias de preço-qualidade usualmente adotadas, conforme o quadro 5.

Quadro 5 - Nove estratégias de preço-qualidade

\begin{tabular}{|c|c|c|c|c|}
\hline & & \multicolumn{3}{|c|}{ Preço } \\
\hline & & Alto & Médio & Baixo \\
\hline \multirow{3}{*}{$\begin{array}{l}\frac{}{0} \\
\frac{0}{0} \\
\frac{0}{0} \\
\frac{\pi}{2} \\
\frac{0}{0} \\
\frac{0}{\bar{T}} \\
\frac{0}{2} \\
\frac{0}{2}\end{array}$} & Alta & $\begin{array}{l}\text { 1. Estratégia de } \\
\text { preço premium }\end{array}$ & $\begin{array}{l}\text { 2. Estratégia de } \\
\text { alto valor }\end{array}$ & $\begin{array}{l}\text { 3. Estratégia de } \\
\text { supervalor }\end{array}$ \\
\hline & Média & $\begin{array}{l}\text { 4. Estratégia de } \\
\text { preço excessivo }\end{array}$ & $\begin{array}{l}\text { 5. Estratégia de } \\
\text { valor médio }\end{array}$ & $\begin{array}{l}\text { 6. Estratégia de } \\
\text { valor bom }\end{array}$ \\
\hline & Baix & $\begin{array}{l}\text { 7. Estratégia de } \\
\text { assalto ao cliente }\end{array}$ & $\begin{array}{l}\text { 8. Estratégia de } \\
\text { falsa economia }\end{array}$ & $\begin{array}{l}\text { 9. Estratégia de } \\
\text { economia }\end{array}$ \\
\hline
\end{tabular}

Fonte: KOTLER, P. Administração de Marketing. São Paulo: Prentice Hall, 2000, p.477.

Observando-se o quadro 5, as estratégias da diagonal são aquelas que podem coexistir no mesmo mercado, desde que haja os três tipos de compradores: os que dão preferência à qualidade, os que privilegiam preços e os que consideram as duas opções. As estratégias de alto valor, supervalor e valor bom contrapõem-se às da diagonal, oferecendo qualidade com economia. As estratégias 4, 7 e 8 dizem respeito à determinação de preço excessivo para a qualidade oferecida, passando ao cliente uma sensação de injustiça.

O estabelecimento do preço do produto está relacionado com o nível de demanda desejado. Em uma situação normal, quanto maior o preço, menor o volume vendido. Para 
artigos em que a qualidade e confiabilidade são valorizados, a curva de demanda pode se inclinar para cima, pois alguns consumidores podem considerar o preço mais alto como indicador de um produto melhor.

A curva de demanda expressa as reações dos indivíduos com diferentes sensibilidades a preço. Alguns fatores podem afetar essa sensibilidade e dos nove que Nagle (apud KotLER, 2000, p.479), os mais representativos para esse estudo são:

- Valor único: os compradores são menos sensíveis a preço quando o produto é exclusivo;

- Consciência da existência dos substitutos: os compradores são menos sensíveis a preço quando não sabem da existência de substitutos;

- Dificuldade de comparação: os compradores são menos sensíveis a preço quando não conseguem fazer comparações;

- Preço-qualidade: os compradores são menos sensíveis a preço quando o produto supostamente apresenta maior qualidade, prestígio ou exclusividade.

Outro aspecto importante na questão preço é a elasticidade de preço da demanda. É provável que a demanda seja menos elástica quando houver poucos substitutos ou concorrentes, quando for difícil para o comprador perceber o preço mais alto imediatamente, quando a mudança de hábito do comprador for lenta para procurar preços mais baixos e quando ele considerar justo um preço elevado pela qualidade oferecida.

A seleção do preço final deverá levar em consideração fatores como a prática de preço psicológico e a influência de outros elementos do mix de marketing sobre o preço._O preço psicológico está relacionado ao fato de que muitos consumidores utilizam o preço como indicador de qualidade e, ao procurarem um artigo, já têm em mente um preço de referência, que pode ser manipulado pelo fabricante para sugerir um posicionamento superior. Quanto aos outros elementos do marketing mix, a qualidade e a propaganda são aspectos que devem estar incorporados na precificação final. Farris e Reibstein (apud KOTLER, 2000, p.490) concluíram por meio de pesquisa que os consumidores se dispõem a pagar mais por produtos conhecidos, que marcas com alta qualidade relativa e alto nível relativo de comunicação obtêm preços mais altos e que a relação positiva entre preços altos e altos níveis de propaganda é mais forte nos estágios finais do ciclo de vida do produto para líderes de mercado. 
Ao analisar a problemática do processamento da informação de preço por parte do consumidor e relacionando-a à qualidade do produto, Suri e Monroe (2003, p.92) trazem importante contribuição:

O preço objetivo de um produto tem significado para os consumidores somente após codificado como uma representação interna. Além isso, em ambientes com informações incertas, o preço serve não apenas como um indicador de sacrifício monetário mas é também um indicador de qualidade do produto. Essa relação entre preço e qualidade percebida é um heurístico que possibilita aos consumidores o uso de um atributo como o preço para fazer julgamentos sobre a qualidade de um produto. Quando os consumidores não estão aptos ou não têm motivação para processar informações de atributos de produto, é mais provável que usem a heurística preçoqualidade ao avaliar uma oferta (RAO; MONROE, 1988). Entretanto, é mais improvável que os consumidores usem o preço como um indicador de qualidade quando têm aptidão e motivação para processar outras informações que auxiliem sua avaliação. Nessas situações, é mais provável que o preço sirva mais como um indicador de sacrifício que de qualidade. Assim, quando o contexto permite ao consumidor processar a informação disponível, o preço provavelmente será usado mais para representar sacrifício que qualidade. Mas quando a situação limita o processamento da informação, é provável que a informação de preço seja usada mais para indicar qualidade que sacrifício.

As percepções de valor, como conseqüência, tendem a seguir a mesma lógica. Os mencionados autores inferem que:

[...] se a relação preço-qualidade for dominante, as percepções de valor do consumidor vão imitar as de qualidade, sendo um produto de alto preço percebido como de alta qualidade, e também de alto valor. Mas se a relação preço-sacrifício predomina, então as percepções de valor dos consumidores refletirão as percepções de sacrifício, sendo um produto de preço relativamente baixo percebido como de baixo sacrifício e, por isso, de alto valor (SURI; MONROE, 2003, p.92).

\subsection{RELAÇÃO ENTRE OS ATRIBUTOS E O COMPORTAMENTO DO CONSUMIDOR}

Um ponto interessante a ser abordado, neste momento, é a forma como se dá o processo de aprendizagem, pelo consumidor, dos atributos de produto como indicadores da sua qualidade, enfatizando-se a distinção entre marca e atributo. Osselaer e Alba (2000, p.1) trazem uma contribuição importante nesse contexto: 
As decisões de compra estão fundamentadas em percepções de desempenho do produto. Os consumidores baseiam suas percepções em parte nos atributos do produto e são mais precisos quanto mais aprendem a relação entre atributo e desempenho [...]. Considerem-se os casos em que os consumidores confiam estritamente ou na marca ou no atributo como indicadores de qualidade. Se os consumidores aprendem o relacionamento entre atributos de produto e qualidade, eles diferenciarão marcas com atributos diferentes e tratarão como commodities aquelas com os mesmos atributos. Uma vez aprendida a regra de correlação, ela pode ser aplicada a qualquer nova marca que compartilhe dos mesmos atributos. Em contrapartida, consumidores que confiam estritamente em marcas irão ignorar os atributos fundamentais e podem diferenciar incorretamente marcas fisicamente idênticas. O último caso é importante porque pode ser custoso e não é incomum [...]. Uma explicação consistente desse fenômeno é que os consumidores não são cientes dos atributos dessas marcas.

O que os referidos autores constatam é que os consumidores valorizam atributos de marcas em detrimento dos atributos de produto e baseiam sua explicação no processo de aprendizagem. De forma simplificada, argumentam que os atributos de marca bloqueiam a aprendizagem dos atributos de produto relacionados à percepção de qualidade.

Estudando como os consumidores utilizam atributos intrínsecos (ligados à parte física do produto) e extrínsecos (não ligados à parte física do produto, como marca, preço etc.) na determinação da qualidade do produto, Lee e Lou (1995 / 1996) chegaram a relevantes conclusões sobre os efeitos das diferenças individuais dos consumidores na importância relativa desses atributos. Assim, os consumidores que têm maior familiaridade e maior envolvimento ${ }^{4}$ com a categoria de produto, confiam mais fortemente em atributos extrínsecos como o nome da marca e o preço. Aqueles que se encontram mais envolvidos na situação de avaliação de produto, confiam intensamente em atributos intrínsecos. Os mencionados autores (1995), citando Etgar e Malhotra (1981), Peterson e Wilson (1985) e Biswas e Blair (1991) apontam que, emuma situação de avaliação de produto, a confiança no preço não é uma regra geral, dependendo de fatores individuais e situacionais e sugerem que alguns consumidores desenvolvem, com o tempo e com base em experiências, para algumas categorias de produto, um esquema preço-confiança (quanto maior o preço, maior a qualidade). Aqueles consumidores mais adeptos a esse esquema são os que se baseiam no atributo preço para a determinação da qualidade do produto.

\footnotetext{
${ }^{4}$ Envolvimento é definido como "a relevância percebida de um objeto com base nas necessidades, valores e interesses de uma pessoa" (ZAICHKOWSKY, 1985).
} 


\section{PARTE III}

\section{DADOS GERAIS SOBRE POPULAÇÃO BRASILEIRA, PERFIL DAS CLASSES DE BAIXA RENDA, PRESERVATIVOS E SEUS HÁBITOS DE USO}

\section{A POPULAÇÃO BRASILEIRA E O PERFIL DAS CLASSES DE BAIXA RENDA}

\subsection{UM PANORAMA SOCIOECONÔMICO DO BRASIL}

Antes de abordar o perfil das classes de baixa renda, foco deste estudo, é pertinente contextualizar a realidade da população brasileira, apresentando alguns cenários evolutivos.

O Brasil experimentou consideráveis mudanças sociodemográficas ao longo do século XX. Estudo do IBGE (2003) mostra que, no século XX, a população brasileira se multiplicou por 10 (gráfico 8) e sua riqueza aumentou 100 vezes. Entre 1920 e 1940, a taxa média de crescimento anual da população brasileira atingia um percentual de 1,49\%. O pico histórico de crescimento populacional ocorreu entre 1950 e 1960, quando a taxa média anual chegou a 2,99\%. Projeções do mesmo Instituto apontam para um índice de 0,71\% em 2020.

Gráfico 8 - Crescimento da população (em milhões de pessoas)

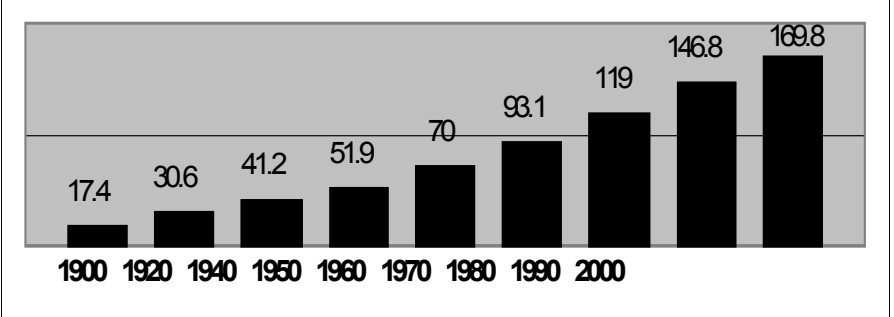

Fonte: Elaborado pelo autor com base em informações do IBGE. Estatísticas do Século XX. Disponível em: $<$ http://www.ibge.gov.br>. Acesso em: 18 nov. 2003.

O Produto Interno Bruto (PIB), que, em 1900, equivalia aproximadamente a R\$ 9 bilhões para uma população aproximada de 17 milhões atingiu a cifra de cerca de R\$ 1 trilhão para uma população de quase 170 milhões de habitantes. Foi um crescimento de 110 vezes. Em outras palavras, o PIB per capita cresceu quase 12 vezes, saltando da casa dos R $\$ 516,00$ 
para significativos $\mathrm{R} \$ 6.056,00$ (gráficos 9 e 10).

Gráfico 9 - Evolução do PIB no Brasil

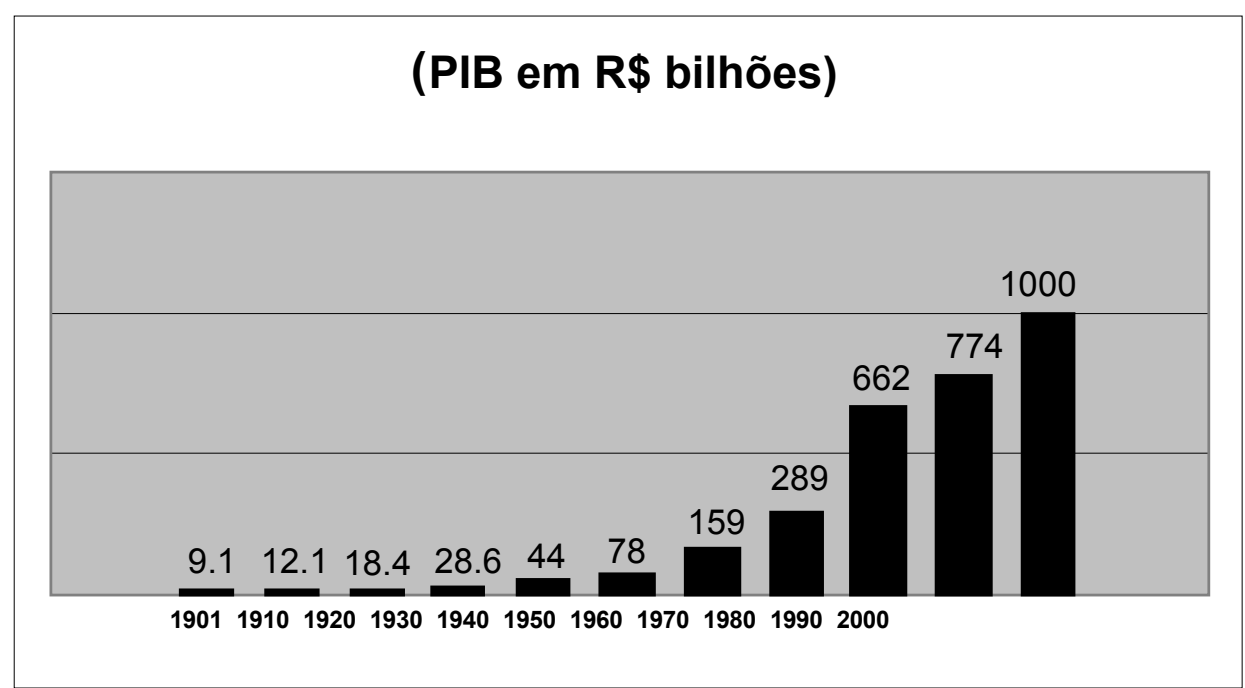

Fonte: Elaborado pelo autor com base em informações do IBGE. Estatísticas do Século XX. Disponível em: $<$ http://www.ibge.gov.br>. Acesso em: 18 nov. 2003.

Gráfico 10 - Evolução do PIB per capita no Brasil (emR\$)

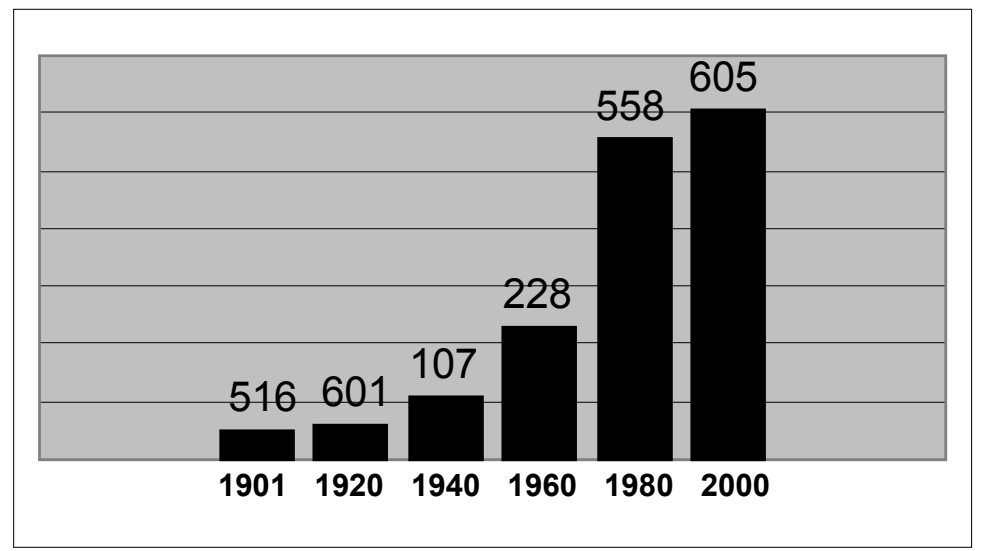

Fonte: Elaborado pelo autor com base em informações do IBGE. Estatísticas do Século XX. Disponível em: $<$ http://www.ibge.gov.br>. Acesso em: 18 nov. 2003.

Apesar disso, constata-se que o crescimento se deu de maneira desequilibrada, favorecendo a escalada da desigualdade social. Enquanto em 1960 a renda dos 10\% mais ricos representava 34 vezes a dos 10\% mais pobres, trinta e um anos depois esse fator passou a ser de 60 vezes. O índice Gini, que mede a desigualdade social, passou de 0,50 para 0,63 no 
mesmo período, chegando mais próximo de 1, o extremo da escala que indica concentração de toda a riqueza com apenas um indivíduo. A gravidade da situação talvez possa ser melhor percebida quando se destaca que $1 \%$ dos cidadãos detém $50 \%$ da renda nacional e quando se coloca o Brasil ao lado de países como Namíbia e Serra Leoa na disputa da liderança do ranking de desigualdade. Esses dados são melhor ilustrados nos gráficos 11 e 12.

Gráfico 11 - Evolução da concentração de renda no Brasil

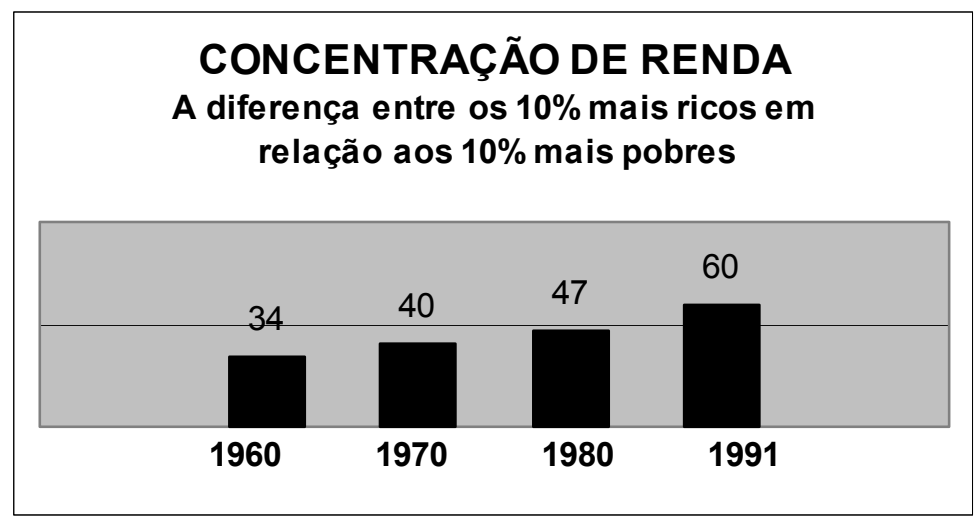

Fonte: Elaborado pelo autor com base em informações do IBGE. Estatísticas do Século XX. Disponível em: $<$ http://www.ibge.gov.br>. Acesso em: 18 nov. 2003.

Gráfico 12 - Índice de Gini

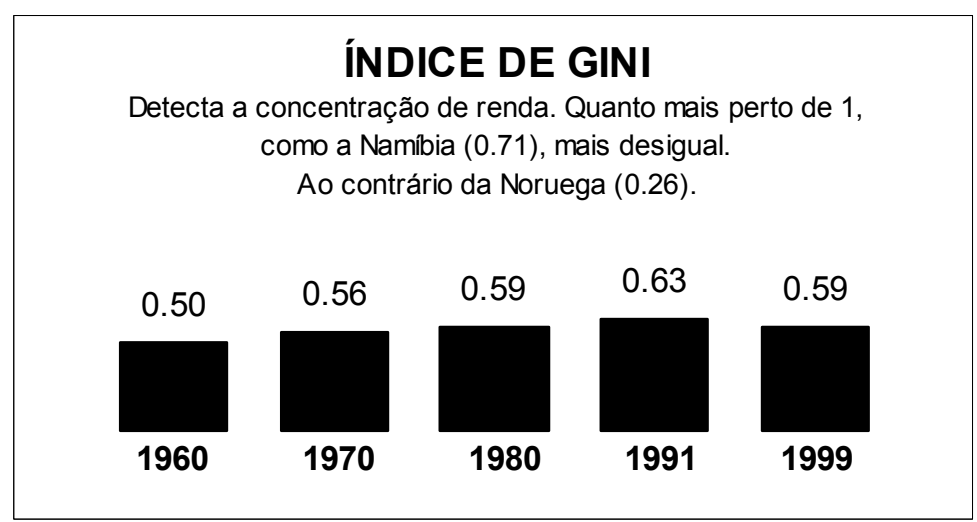

Fonte: Elaborado pelo autor com base em informações do IBGE. Estatísticas do Século XX. Disponível em: $<$ http://www.ibge.gov.br>. Acesso em: 18 nov. 2003.

Nos cem anos que se passaram, também pôde se perceber o fenômeno da urbanização. O mesmo estudo do IBGE (2003) destaca que os residentes no campo passaram de $69 \%$ em 1940 para apenas $19 \%$ em 2000 , o que teria trazido melhorias na qualidade de vida do 
brasileiro. O acesso à saúde foi uma delas, com impacto direto na taxa de crescimento da expectativa de vida, que passou de 33, 6 anos em 1900 para 68,6 anos em 2000 e na redução da mortalidade infantil, que caiu de 162,4 óbitos por mil crianças nascidas vivas para 29,6 por mil (gráficos 13 e 14).

Gráfico 13 - Evolução da expectativa de vida no Brasil

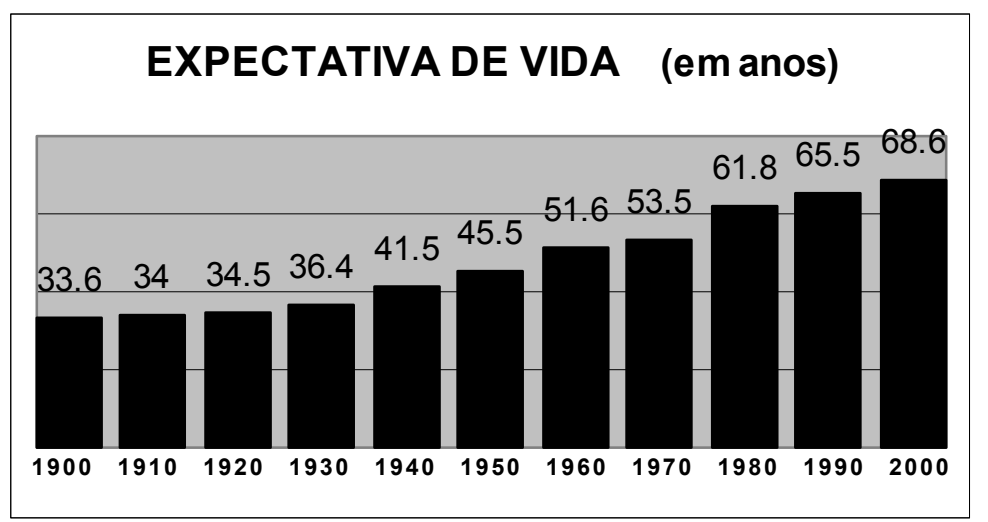

Fonte: Elaborado pelo autor com base em informações do IBGE. Estatísticas do Século XX. Disponível em: $<$ http://www.ibge.gov.br>. Acesso em: 18 nov. 2003.

Gráfico 14 - Evolução da mortalidade infantil no Brasil

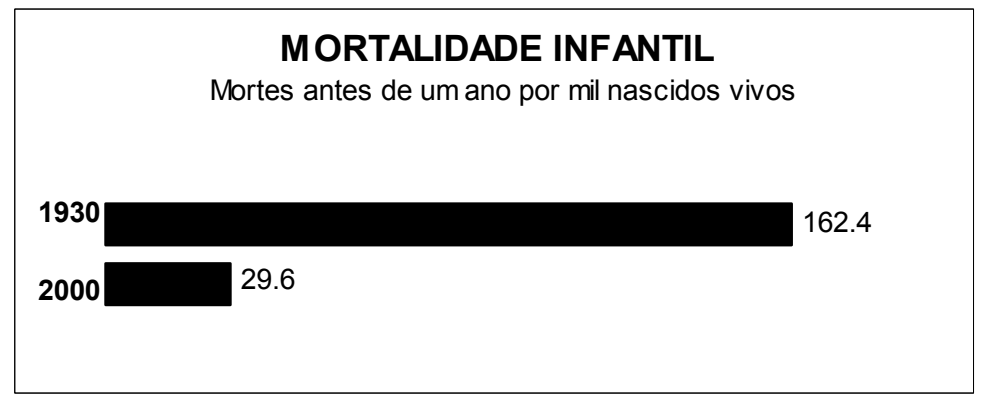

Fonte: Elaborado pelo autor com base em informações do IBGE. Estatísticas do Século XX. Disponível em: $<$ http://www.ibge.gov.br>. Acesso em: 18 nov. 2003.

Trazendo o foco de análise para a década de 1990, o retrato que se observa é de um Brasil que experimentou mudanças positivas em seus indicadores sociais, como resultado dos investimentos efetuados. Conforme a Pesquisa Nacional por Amostra de Domicílios - PNAD 2002 do IBGE (2002), os brasileiros passaram a contar com muito mais serviços. De 1992 a 2002, cresceu o número de domicílios com linha telefônica fixa de 19\% a 61,6\%, e, nesse ano, 
9\% das moradias faziam uso apenas da telefonia móvel; tal fenômeno é conseqüência direta dos processos de privatização pelos quais passou o País a partir de 1998. Reduziu-se significativamente o percentual de residências sem iluminação elétrica (de 11,2\% para 3,3\%), sem coleta de lixo (de $33 \%$ para 15,2\%), sem rede geral de abastecimento de água (de 26,4\% para $18 \%$ ) e sem esgotamento sanitário adequado (de $43,3 \%$ para $31,9 \%$ ).

A referida pesquisa ainda apontou o aumento generalizado do número de eletrodomésticos por parte dos brasileiros, principalmente devido à explosão de consumo ocorrida após o Plano Real de 1994. Assim, no intervalo de 1992 a 2002, aumentou o número de lares com geladeira (de $71,5 \%$ para $86,7 \%$ ), freezer (de $12,3 \%$ para $18,5 \%$ ), lavadora de roupa (de $24,1 \%$ para $34 \%$ ), rádio (de $84,9 \%$ para $87,9 \%$ ) e televisão (de $74 \%$ para $89,9 \%$ ).

No tocante à educação, a PNAD 2002 mostra números animadores. No intervalo dos dez anos em foco, a taxa de escolarização cresceu significativamente no grupo de 5 a 17 anos (correspondente ao período em que as crianças deveriam estar cursando o ensino pré-escolar, fundamental e o médio), o que se observa pelo recuo de $24,2 \%$ para $9,7 \%$ do total de crianças dessa faixa etária que não freqüentava a escola. Essa evolução é fortemente atribuída aos programas sociais voltados para a educação. Na mesma direção, caminhou o analfabetismo, com recuo significativo: entre os brasileiros de 10 anos ou mais, o índice baixou de $16,4 \%$ em 1992 para 10,9\% em 2002.

O trabalho infantil, por sua vez, apresentou considerável melhora, registrando forte redução dos indicadores de 1992 para 2002 (de 19,6\% das crianças e adolescentes de 5 a 17 anos para $12,6 \%)$.

A população passou por um processo de envelhecimento, tendo aumentado de $7,9 \%$ para 9,3\% a proporção de pessoas com mais de 60 anos no período; por outro lado, verificouse uma redução do número de crianças de 1992 a 2002, tendo a proporção da faixa de 0 a 4 anos se reduzido de $10,6 \%$ para $8,7 \%$.

Talvez um dos aspectos de maior destaque ocorridos na década de 1990, do ponto de vista socioeconômico, seja a mobilidade social verificada principalmente nos estratos mais baixos da pirâmide de classes. De 1992 a 2000, o que pode ser constatado pelas estatísticas do IBGE (apud BCG, 2002) são movimentos ascendentes nas classes C e D, trazendo importantes conseqüências para o mercado de consumo do Brasil neste período. A seção seguinte aborda essa questão e traz uma visão geral sobre o perfil das classes populares. 


\subsection{A POPULAÇÃO DE BAIXA RENDA}

\subsubsection{Perfil}

Após a implementação do Plano Real no Brasil em 1994, muitos consumidores de baixa renda tiveram a oportunidade de ingressar em mercados pelos quais previamente passavam longe. Com a redução do imposto inflacionário, esses brasileiros começaram a ter acesso a novos produtos ou até aumentaram a freqüência de compra de itens que já adquiriam anteriormente.

Segundo estudo do BCG (2002), em conseqüência de os consumidores de renda mais elevada e consumo próximo à saturação serem cada vez mais disputados por uma oferta de produtos e serviços altamente competitiva, as classes de baixa renda tornaram-se importante oportunidade para empresas que estão buscando novas alternativas de crescimento.

Para se compreender a representatividade do potencial de consumo dessa faixa da população, basta analisar o que ocorreu com a classe $\mathrm{C}$, talvez a mais importante fatia que a integra. Composta por famílias com renda mensal entre quatro e dez salários mínimos, segundo estudo do BCG (2002), esse segmento apresentou crescimento entre 1992 e 2000 de aproximadamente 3,4 milhões no número de famílias, alcançando um potencial de consumo próximo a $\mathrm{R} \$ 226$ bilhões anuais.

Esses números sugerem que o estudo do comportamento do consumidor de baixa renda pode ter valor especial, em um momento em que esse indivíduo se configura como uma alternativa para a expansão dos mercados de consumo.

O referido estudo mostra que as classes C, D e E, são constituídas por cerca de $81 \%$ dos domicílios brasileiros. Observando a distribuição dos domicílios por toda a pirâmide de classes, tem-se o seguinte retrato: 19\% deles são ocupados pelas classes A / B; 30\% pela C e $51 \%$ pela D / E. Essas informações estão ilustradas na figura 5. Especificamente, a classe $\mathrm{C}^{14}$ é responsável por $28 \%$ do consumo nacional, equivalente a $\mathrm{R} \$ 226$ bilhões por ano em compras, o que aponta para um enorme potencial a ser explorado (figura 5). Tão importante quanto esse fato é o movimento migratório de parte da classe D para o nível C e de parte da classe $\mathrm{C}$ para o nível B, ressaltando ainda mais as oportunidades desses segmentos.

\footnotetext{
${ }^{14}$ No estudo do BCG (2002), o critério de classificação levou em conta as seguintes faixas de renda familiar mensal: classe D/E, de 0 a 4 salários mínimos; classe $\mathrm{C}$, de 4 a 10 salários mínimos; classe $\mathrm{A} / \mathrm{B}$, mais de 10 salários mínimos.
} 
Figura 5 - Perfil das classes sociais no Brasil

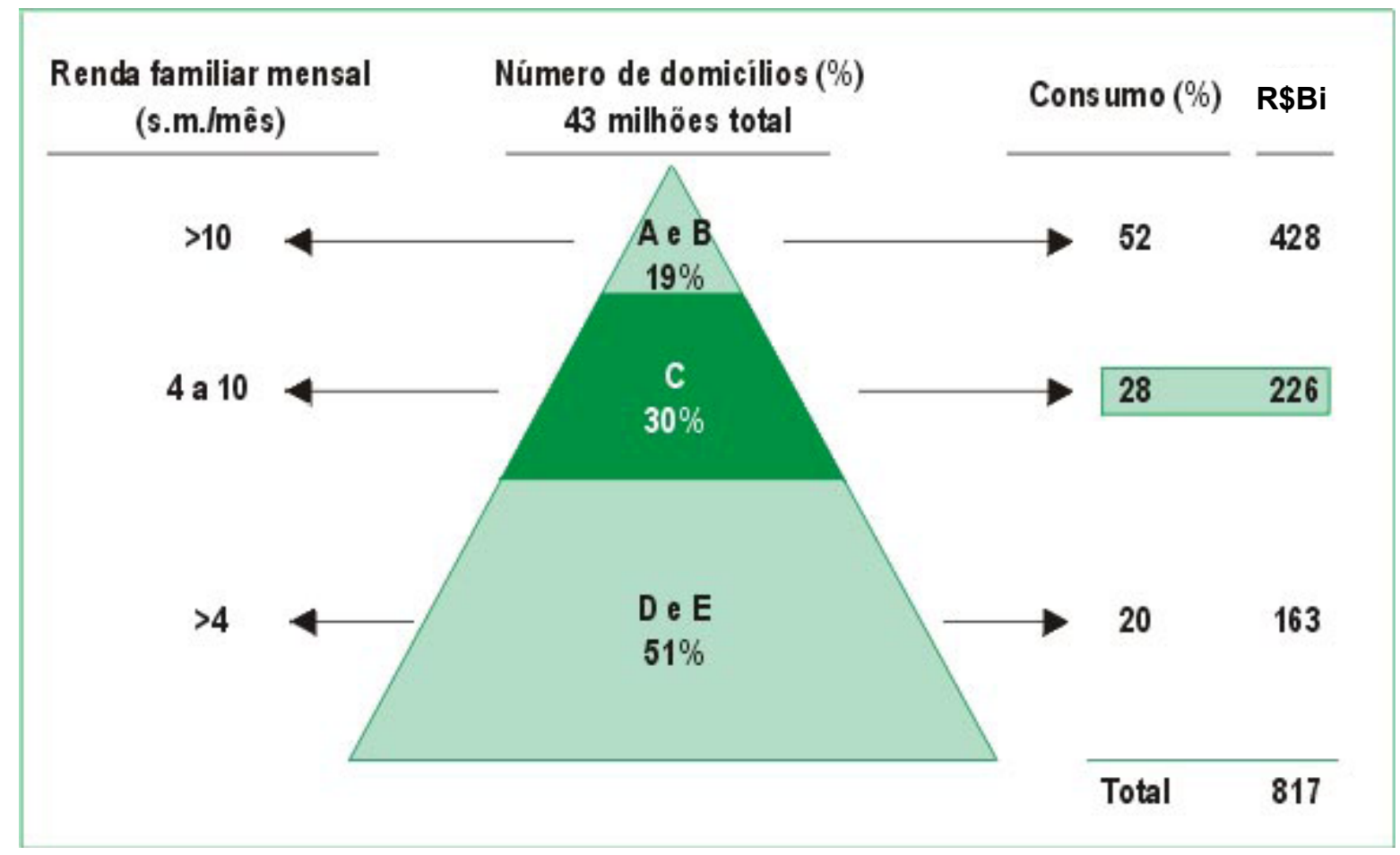

Fonte: THE BOSTON CONSULTING GROUP. Mercados Pouco Explorados: Descobrindo a Classe C. São Paulo. 2002. Disponível em <http://www.bcg.com>. Acesso em: 20 set. 2002. p.13.

Figura 6 - Taxa anual de crescimento composto

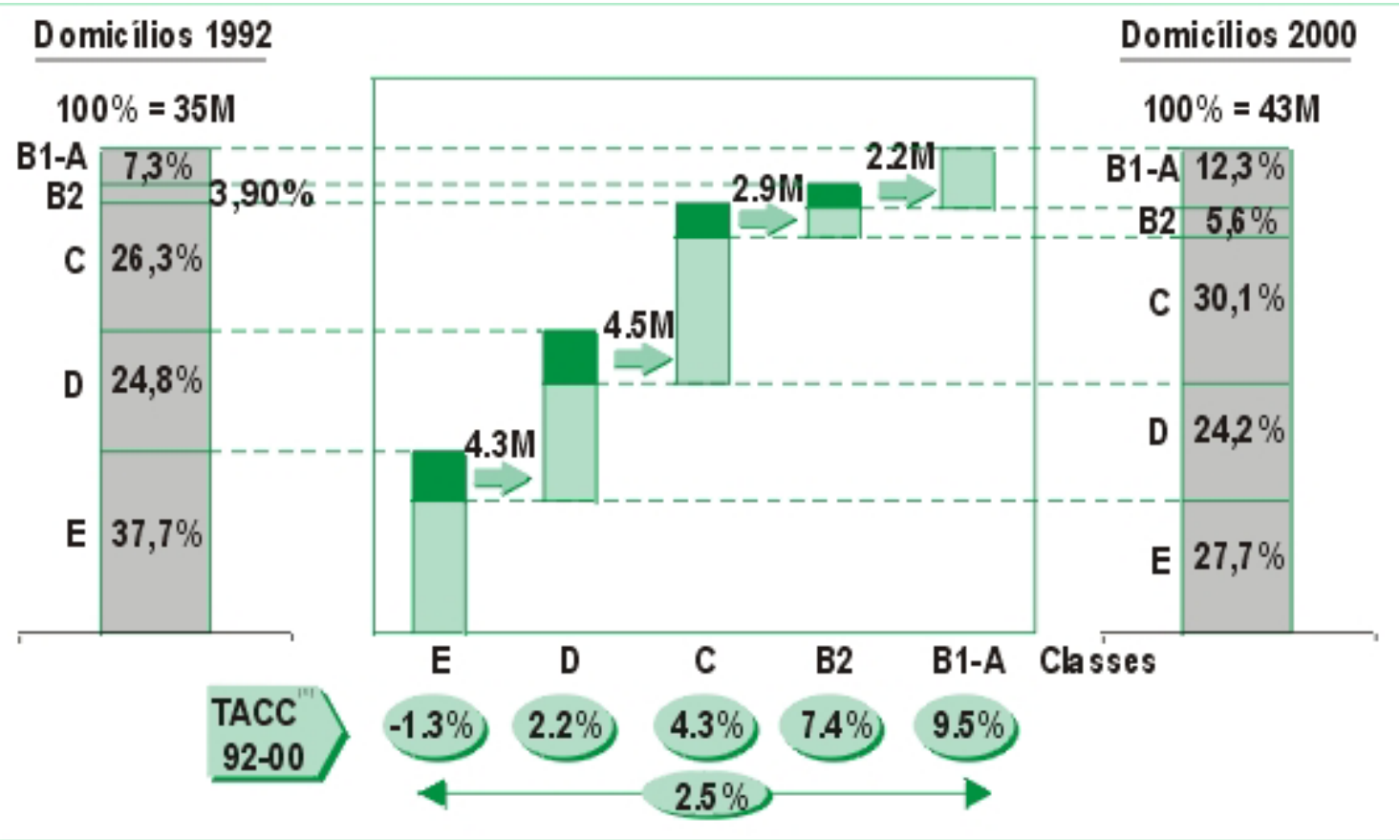

Fonte: BOSTON CONSUlTING GROUP. Mercados Pouco Explorados: Descobrindo a Classe C. São Paulo. 2002. Disponível em $<$ http://www.bcg.com>.Acesso em: 20 set. 2002. p.13. 
O BCG (2002, p.13) comenta:

Em 1992, segundo dados do IBGE, a classe C representava 26,3\% da população e estava espremida entre os $3,9 \%$ da classe B2 e os $24,8 \%$ da classe D. Já em 2000, a classe C passou a representar 30,1\% da população. Nesse período, o índice de mobilidade social médio foi de $2,5 \%$ em direção ao topo da pirâmide, permeando todas as classes.

Essa observação pode ser visualizada na Figura 6.

Em termos de posse de bens, a classe $\mathrm{C}$ apresenta-se como possuidora de grande parte dos equipamentos básicos da vida urbana. O mencionado estudo aponta que $100 \%$ dos entrevistados possui televisor, rádio e geladeira; $69 \%$ possui telefone fixo; $67 \%$ dispõe de videocassete; $56 \%$, de máquina de lavar roupas; e 42\%, de automóvel. Alguns itens de conforto, com presença praticamente certa nos domicílios da classe A / B, como aspirador de pó, computador, TV por assinatura, acesso à Internet e contratação de serviços domésticos, ainda não fazem parte da sua realidade. Isso pode ter uma razão:

Todos os itens que demandariam um certo nível de comprometimento de longo prazo, como assinaturas de TV ou Internet, ou até mesmo o salário de empregados domésticos, ainda estão cercados de um certo receio por parte desse consumidor. Já para bens duráveis, este consumidor aceita tomar algum endividamento, mesmo assim comprometendo uma pequena parte da sua renda mensal (BCG, 2002).

No tocante à posse de produtos financeiros, apesar de o rendimento mensal ser restrito, a classe C já se mostra como usuária intensa deles, conforme mostra o BCG (2002, p.14):

\footnotetext{
Hoje, 47\% dos domicílios da classe $\mathrm{C}$ possuem pelo menos um morador com contacorrente; $19 \%$ utilizam cartão de débito, $16 \%$ têm cheque especial, 33\% possuem limites de crédito pré-aprovados, $16 \%$ trabalham com cartão de crédito e $38 \%$ utilizam cartão de loja. Mas ainda existem 25\% dos domicílios de classe C sem qualquer um destes produtos[...]
}

Além disso, quando o assunto é poupança, para $80 \%$ dos domicílios da classe $\mathrm{C}$, ao contrário do que se poderia imaginar, sobram recursos mensalmente. Mesmo que em pequena quantidade, esses recursos são direcionados para uma reserva que visa realizar o sonho da casa própria, precaver-se quanto a eventuais problemas circunstanciais ou garantir o futuro dos filhos. O resultado apresentado aponta para sobras médias mensais de R\$ 128,00 para aquela proporção de domicílios; para 13\% deles, chega a sobrar até $\mathrm{R} \$ 300,00$ mensais por 
família. Devido à cultura da poupança, a pesquisa mencionada apontou para um endividamento controlado dessa parcela da população, tendo sido constatadas dívidas em apenas $30 \%$ dela. Os ativos comprometidos não passam de aproximadamente um salário mensal da família, o que é relativamente baixo quando comparado ao nível de endividamento médio do americano. $\mathrm{Na}$ classe $\mathrm{C}$, o endividamento mais significativo dá-se para bens duráveis.

\subsubsection{Estilos de Vida}

A classes populares apresentam um estilo de vida que valoriza os pequenos prazeres do cotidiano. Conversar no bar com os amigos, acompanhado de uma cerveja gelada; visitar parentes junto com a família; tragar um cigarro; ter um televisor ou um aparelho de som; poder apreciar uma boa comida; vivenciar relacionamentos afetivos e relaxar. Essa é uma pequena amostra dos sentimentos relatados por respondentes daquelas classes, em pesquisa da Almap/BBDO (1996). Por terem pouca perspectiva de sair do processo de deterioração do qual se sentem vítimas, essas pessoas buscam estruturar seu modo de vida segundo uma "mentalidade de sobrevivência", em que a carga a transportar deve ser leve e a simplicidade, a tônica.

A valorização da casa e da família representam a forma como esses brasileiros procuram neutralizar o sentimento de exclusão vivido no mundo externo, e os filhos são os fiéis depositários da esperança de um dia poderem se inserir em uma sociedade mais ampla. Assim, a pesquisa complementa:

[...] pode-se dizer que o imaginário desse consumidor é dominado pela utopia de uma segunda chance de ser feliz, onde a ascensão profissional do filho resgata a estrutura do conto de fadas: uma história que começa mal, com sofrimento, mas termina com final feliz. Conforme a tendência mundial que revela que, por falta de segurança e proteção as pessoas tendem ao "enclausuramento doméstico", o consumidor emergente também procura tornar sua casa um refúgio de prazer onde encontra supridas suas prioridades básicas. [...] Os instantes de prazer de cada um no espaço da casa podem ser definidos como o espaço da liberdade. Esses momentos correspondem a uma espécie de "festa", onde o descontínuo (a pausa) se sobrepõe ao contínuo, que é a "batalha pela vida" na rua, o universo da polêmica, do desgaste e da luta. Através desses pequenos prazeres, pode-se rastrear o percurso gerativo de um prazer maior: o prazer de poder nada fazer, usufruindo da liberdade de estar só, de "ficar sossegado", de ser dono do próprio tempo sem precisar dividir o pouco espaço da casa com outros da família. Para então poder "viajar" através da leitura, penetrar na aventura ou obter 
descontração através das novelas e filmes da TB, o relaxamento e a vazão aos sonhos, a música (ALMAP/BBDO, 1996, p. 38).

Os indivíduos das classes populares aproveitam, das mais diversas formas, o tempo livre em busca do prazer. A música é uma delas e seu valor encontra-se na possibilidade terapêutica da reflexão e do alívio das dores e frustrações. Ouvi-la em posição de relaxamento, acompanhado de uma bebida e de um petisco, pode representar a mistura do nada fazer com a ação simulada. Sendo a casa o templo desse ritual, desse momento de prazer, a tendência natural é a de sobrevalorização dos equipamentos domésticos, como aparelhos de som e televisores, que se tornam objetos de desejo e fazem com que os consumidores emergentes se sintam mais próximos das demais classes.

Esse sentimento é fruto da sua aspiração por uma vida melhor e se reflete na imagem que fazem de si próprios. Analisando especificamente os integrantes da classe C, o BCG (2002) aponta que eles se percebem no estágio intermediário entre a classe média / ricos, dos quais se consideram muito distantes, e os miseráveis, dos quais sentem compaixão, considerando o medo que têm de uma queda na escala social. Prova disso é que, em média, $3 \%$ da renda do indivíduo da classe $\mathrm{C}$ é aplicada em contribuições de caridade.

Ao tratar da felicidade, o consumidor de baixa renda coloca-a em um plano mais abstrato que o do prazer. Enquanto este último funciona sob a dinâmica concreta do fazer e do criar, que depende só de si, aquele opera na esfera mais distante do ter e do estar, que é função de uma luta, uma conquista. É o que a pesquisa Almap/BBDO (1996, p.41) comenta:

O discurso da felicidade tem um tom quase religioso e traz, subjacente, a idéia de merecimento (prega valores como honestidade, sinceridade). Talvez porque a própria palavra felicidade lhe remeta a "coisas maiores", mas menos tangíveis como Deus, saúde, paz, harmonia, amor e prosperidade [...] A felicidade, para o consumidor emergente, vai do concreto para o abstrato, da casa, saúde, emprego e dinheiro à amizade, paz, amor alegria e sucesso. [...] A felicidade se encontra, no seu sentido mais profundo, no bem estar e esta é a síntese entre o possível e o sonhado, entre a fantasia e a realidade. [...] Não se abandona o sonho, pois é ele que viabiliza a vida ao viabilizar sensibilidade, a capacidade de se maravilhar diante do belo (expresso na música, nos reluzentes carros, nas "viagens" promovidas pelos filmes e livros, nas viagens para lugares aprazíveis em hotéis com "mordomias", ou ainda, no prazer de adquirir produtos, marcas possíveis como ponto de partida para se chegar lá; lá é o sucesso"). A linguagem se cobre de concretude, deixando transparecer uma ideologia social determinada: a conquista pelo esforço e determinação. O discurso não encerra 
uma explicação última da felicidade e sim uma materialidade própria ligada às necessidades: uma boa alimentação, um lar confortável, um bom emprego, relacionamentos de amor e amizade, num equilíbrio de vida sem exageros, onde retira-se alegria das coisas mais simples e comuns da existência. A felicidade é, pois, a totalidade do sucesso que se pretende e que contém em seu cerne um limite. No discurso, há alguma coisa de ambição como há de modéstia, e ambas estão aderentes àquele limite interno imposto pela condição financeira e pela autocensura.

\subsubsection{Comportamento de Compra e Estilos de Consumo}

A classe C tem outras peculiaridades ressaltadas pelo estudo do BCG (2002). Alimentação e moradia são os itens apontados como os que mais consomem recursos - $65 \%$ dos gastos mensais, divididos em despesas com supermercado (48\%), e com a manutenção do domicílio, como água, luz, aluguel, condomínio, prestação da casa e IPTU (17\%). A participação do lazer é de apenas 3\% dos gastos mensais, o que permite associar um certo caráter lúdico às compras desses consumidores, traduzido em prazer e auto-satisfação na aquisição de certas marcas e / ou itens.

Como conseqüência das alterações no cenário econômico do País, provocadas pela implementação do Plano Real, a partir de 1994, os consumidores emergentes experimentaram uma mudança em seu estilo de comprar, com características mais próximas das dos indivíduos de outras classes mais altas, em que outros valores são considerados. Conforme a pesquisa Almap/BBDO (1996), despertou-se a atenção para a qualidade, e o consumo passou a concretizar desejos e não apenas satisfazer necessidades Algumas ponderações, contudo, são feitas a respeito dessa transição:

Permanecem algumas especificidades de estilo de consumo ditadas pela própria condição econômica, que norteia a interpretação e reinterpretação dos traços dos valores imitados. Há uma gradação nessa transição, aparentemente em função de idade (mais jovens versus mais velhos) e poder aquisitivo (classe C versus classe D), tendo sido identificados, dentro da amostra de consumidores emergentes consultados, dois modelos diferenciados: o modelo das aquisições e o modelo da imersão no consumo. A pesquisa retrata este movimento do modelo de aquisição (compra só necessário) para o modelo de imersão no consumo, que tende a se tornar expressivo cada vez que há um incremento real na renda das classes mais baixas. Durante muito tempo, a classe de baixa renda amargou o sentimento de exclusão da sociedade de consumo. Esta classe não se sentia considerada pelo marketing, pela propaganda e pelo varejo das empresas. O incremento do poder aquisitivo [...] tende a mudar as regras do jogo, fazendo com que aumente a necessidade de adequação do diálogo 
entre as partes: o lado da oferta (fabricantes, propaganda e varejo) e o lado da demanda. (ALMAP/BBDO, 1996, p. 6).

Outros reflexos foram observados no estilo do consumidor de baixa renda com a chegada do Plano Real. Além da percepção de que passou a sobrar mais dinheiro no final do mês pela ausência do imposto inflacionário, ele passou a comprar uma quantidade mais comedida, com programação e parcelamento, sem o desejo de estocar produtos por medo da subida dos preços. A estabilização econômica também facilitou a pesquisa de preço, o que permitiu torná-lo mais sensível a diferenças de qualidade. A predisposição ao consumo imediato aumentou, como resposta aos desejos de consumo reprimidos por muito tempo, sendo relevada a questão do preço diante do valor da prestação, novo foco de interesse. Mesmo a taxa de juros foi relegada a segundo plano.

Um dos ângulos pelos quais se pode analisar o estilo de consumo de um indivíduo é a forma como ele adquire um bem. Segundo a Almap/BBDO (1996, p.11), o ato da compra "se por um lado é prazeroso para o consumidor de baixa renda, por outro é angustiante, uma vez que a possibilidade de reposição de uma má compra é remota”. A experiência concreta com o produto é importante para esse tipo de comprador; principalmente se representar uma vivência anterior (pessoal ou de terceiros) ou imediata do tipo sensorial, em que ele tem a oportunidade de tocar o produto e testar seu funcionamento; outro fator relevante é o aval de uma boa marca. A busca por qualidade é uma constante, pois se traduz em segurança e satisfação; a segurança é representada pelos prazos de validade (caso dos produtos perecíveis) e pelos maiores prazos de garantia que são os indicadores de durabilidade e resistência (caso dos bens duráveis).

Mapeando o consumo de bens não duráveis, o estudo do BCG (2002) apresenta um quadro sobre os hábitos de compra da classe econômica em estudo. Representando cerca de $62 \%$ do consumo total da classe $\mathrm{C}$, figuram as compras de abastecimento, integradas por itens imprescindíveis, como alimentos (correspondem ao maior investimento), limpeza do lar e higiene pessoal. Outros $30 \%$ do consumo total estão associados às compras de reposição, normalmente realizadas em feiras e mercados de vizinhança e com peculiaridade de serem pagas à vista.

Pelo estudo mencionado, a duração da compra de abastecimento geralmente é de uma a três horas, enquanto, no processo de reposição, o tempo médio é bem menor. As condições financeiras restritas da classe $\mathrm{C}$ fazem com que a compra de reposição represente uma parcela 
significativa dos gastos mensais dessa classe. Os alimentos mais freqüentes nas listas de compra são: arroz, feijão, batata, cebola, café em pó, pão francês, carne, frango, verduras e legumes, farinha de trigo, leite em caixinha, macarrão, margarina, óleo de soja, sal, dentre outros.

Nas listas de produtos de limpeza do lar, os mais usuais são a água sanitária, o detergente líquido, o papel higiênico e o sabão em pó. O BCG (2002) ainda tece considerações sobre os itens de higiene pessoal, destacando que os mais presentes são absorvente higiênico, aparelho de barbear, creme dental, desodorante, sabonete e xampu. Outros itens que costumam fazer parte da lista dos imprescindíveis, na escassez do dinheiro, acabam sendo desprezados. É o caso da maionese, leite condensado, iogurte, frios, pão de forma, amaciantes de roupa, guardanapos de papel, inseticida, sacos de lixo, creme de barbear, fio dental, xampus, dentre outros.

Alguns itens são considerados supérfluos, porém desejados e acabam tendo um peso considerável nas compras de abastecimento e reposição, conforme o referido estudo. É o caso da cerveja, doces, sucos de fruta, salgadinhos em sacos, graxa para calçado, escova dental. Tomando o exemplo da cerveja, em que apenas $2 \%$ dos consumidores a adquirem em caráter esporádico, isto é, a grande maioria a adquire com freqüência, é importante notar que alguns bens de consumo apresentam um papel significativo na satisfação das necessidades de compensação e prazer da classe $\mathrm{C}$.

\subsubsection{Escolha das Marcas}

A marca é um atributo relevante no processo de escolha das classes de baixa renda, principalmente porque associa qualidade ao produto que está sendo procurado. Segundo pesquisa da Almap/BBDO (1996), os consumidores de baixa renda pautam-se fortemente por esse fator durante o processo de escolha; no entanto, um outro ingrediente vem se integrar à dinâmica da decisão e torná-la mais complexa: o preço. Dessa forma, passa a ser importante analisar como o indivíduo das classes populares se porta diante da relação preço versus qualidade:

Embora sua escolha seja muitas vezes orientada por preço, ele discrimina claramente as marcas de qualidade das marcas que têm como única vantagem o preço. Estas últimas são escolhas circunstanciais, dependendo da disponibilidade financeira do momento. Em algumas categorias, este consumidor emergente não abre mão de marcas de qualidade, independente de preço. [...] As marcas que têm maior notoriedade para este consumidor (maior visibilidade na mídia e maior aceitação no 
grupo de referência) desempenham importante função na relação do consumo. Através delas, o consumidor pode aumentar o nível de certeza com relação à sua escolha e pode também exercitar o seu poder [...] (ALMAP/BBDO, 1996, p.4).

O consumidor da classe $\mathrm{C}$, quando avalia marcas, analisa um leque de opções que vai da mais conhecida até a de segunda linha, passando pela marca própria ${ }^{5}$. Segundo o estudo do BCG (2002), quando se trata desse último caso, para tomar sua decisão de compra, o consumidor não se baseia unicamente no aspecto preço. Sem dúvida, esse fator é relevante, tendo um peso de $31 \%$ a $38 \%$ nos motivos que levam à compra; porém, outro fator muito valorizado por essa classe é o status que uma marca avalizada e reconhecida pelos grupos de influência pode determinar, independentemente da faixa de renda do consumidor ou da categoria do produto em questão. Já quando se trata de uma marca conhecida, o comportamento do consumidor diferencia-se de acordo com a categoria do bem em aquisição. Em alimentos, o preço / promoção é responsável por 38\% da decisão de compra, enquanto $45 \%$ correspondem aos atributos de qualidade (prazo de validade, sabor / cheiro, rendimento e desejo de agradar a família); apenas $13 \%$ são devidos à marca reconhecida. Se o bem for de higiene pessoal, $31 \%$ da decisão se dá por preço / promoção e $38 \%$ por atributos de qualidade (cheiro, prazo de validade, desejo de agradar a família e rendimento); a marca reconhecida, por sua vez, tem um peso de $22 \%$ nessa categoria. No caso do bem ser de limpeza, $31 \%$ da decisão de compra é por preço / promoção e 39\% por atributos de qualidade (cheiro, rendimento, prazo de validade, grau de praticidade e desejo de agradar a família); apenas 16\% são devidos à marca reconhecida. Esses dados estão ilustrados na figura 7.

O BCG (2002) também retrata que, por não haver sobras significativas de verba para consumo no final do mês, como já pode ser observado nessa seção, existe uma séria preocupação por parte do consumidor de classe C com o binômio preço / qualidade ${ }^{6}$ almejada, uma vez que qualquer erro de aquisição tem pouca chance de ser corrigido, dada a indisponibilidade de recursos. Esse fator, associado à busca de uma boa qualidade, acaba por impedir a fidelidade a uma única marca, abrindo um leque de marcas selecionadas, testadas e avalizadas pelos grupos sociais de influência e direcionando a decisão de compra segundo uma escala de variáveis que vai da marca mais barata, quando a situação é de escassez, até a

\footnotetext{
${ }^{5}$ Segundo Churchill e Peter (2000, p.246), marca própria é uma marca de propriedade de uso de um atacadista ou varejista.

${ }^{6}$ Segundo a pesquisa do BCG (2002), qualidade, para os consumidores dessa classe é a integração de uma série de quesitos representados por reconhecimento de marca, embalagem adequada, produto bem apresentado, resistência, durabilidade, rendimento adequado, enquadramento no prazo de validade, garantia, serviços ao consumidor e aprovação pelo grupo social.
} 
Figura 7 - Atributos avaliados pela classe $\mathrm{C}$ na escolha da marca

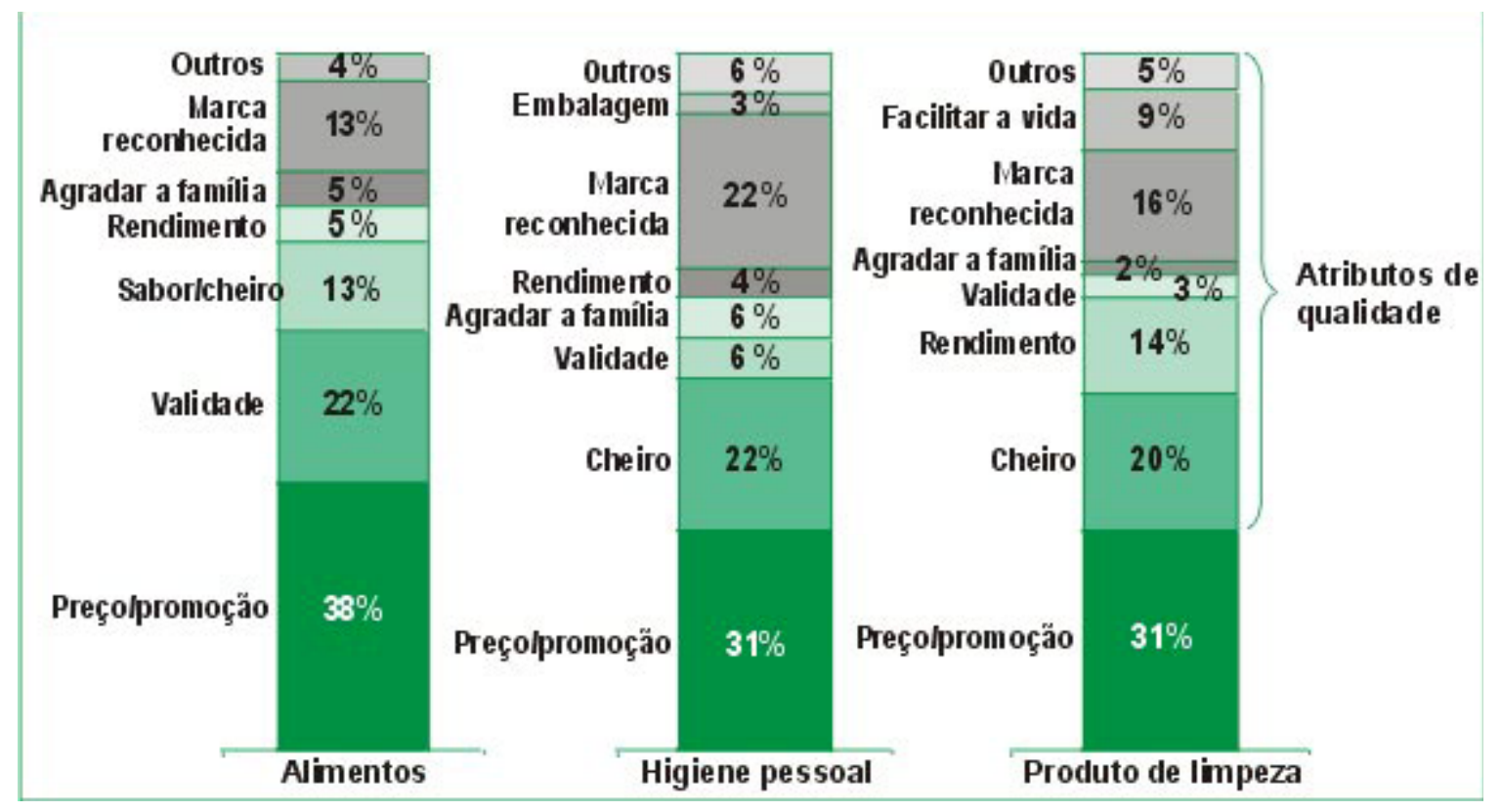

Fonte: BOSTON CONSUlTING GROUP. Mercados Pouco Explorados: Descobrindo a Classe C. São Paulo. 2002. Disponível em $<$ http://www.bcg.com>.Acesso em: 20 set. 2002. p.13.

marca preferida, em situação normal. O que reduz o risco de erro é uma pré-qualificação das marcas, o que, segundo a pesquisa, deixa em desvantagem as marcas próprias, que ainda precisam de tempo para conquistar a preferência do consumidor.

Entre os consumidores que já compraram produtos de marcas próprias, $47 \%$ queriam experimentá-las e 38\% foram compelidos pela necessidade financeira. Apenas 10\% dos consumidores que já compraram marcas próprias o fizeram pela qualidade reconhecida, enquanto $29 \%$ dos que nunca compraram estas marcas desconfiam desse quesito. É curioso notar que o consumo de marcas próprias cresce levemente com o aumento da renda familiar e com o nível de escolaridade dos entrevistados (BCG, 2002, p.20).

Outro aspecto interessante de se analisar, presente nas decisões de compra das classes inferiores, diz respeito ao comportamento de troca de marca. Estudo do BCG (2002) destaca que a classe $C$, em particular a grande maioria das mulheres, satisfaz-se com três marcas principais, mas sempre elege opções mais baratas com qualidade aceitável. O potencial de troca dentre as marcas conhecidas é alto, sendo 50\% o índice das consumidoras que comparam os preços e escolhem a mais barata, $23 \%$ o das que levam outra marca qualquer, $15 \%$ o das que mantêm fidelidade a uma única marca e $12 \%$ o das que levam a mais barata da 
categoria. De forma geral, as consumidoras dessa classe resistem a baixar o nível do que percebem como qualidade e, quando há restrição de recursos, $43 \%$ levam a marca conhecida mais barata, 30\% levam outro produto no lugar, 14\% levam outra marca qualquer e $13 \%$ não compram por não estarem dispostas a trocar de marca. Essas informações estão ilustradas na figura 8. A troca por uma marca conhecida mais barata é atitude adotada pela maioria dos consumidores em todas as categorias de produto, mas ocorre com menor freqüência naquelas em que haja atribuição de satisfazer desejos da família e proporcionar prazer e compensação.

Figura 8 - Potencial de troca entre marcas

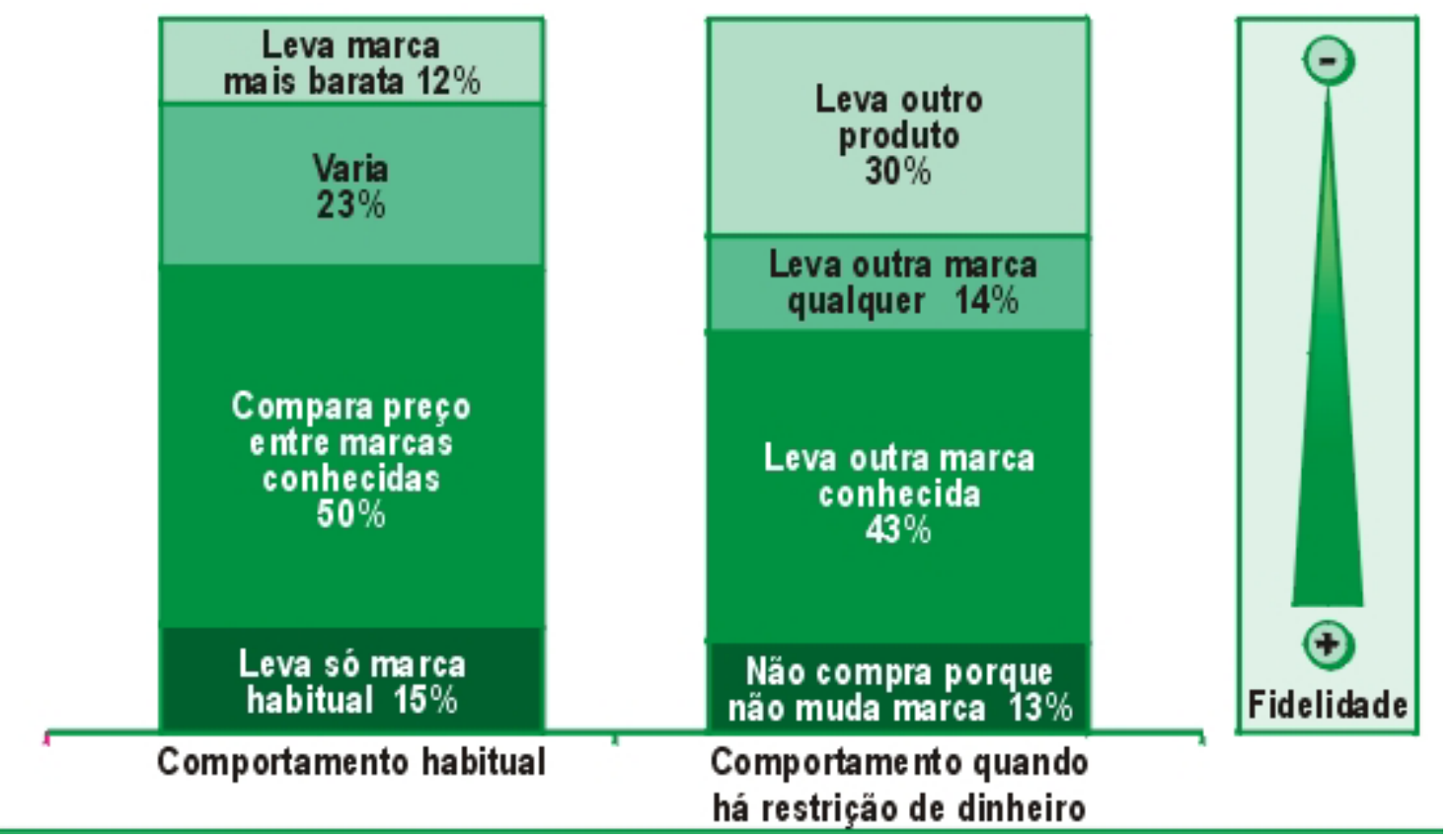

Fonte: BOSTON CONSUlTING GROUP. Mercados Pouco Explorados: Descobrindo a Classe C. São Paulo. 2002. Disponível em $<$ http://www.bcg.com>.Acesso em: 20 set. 2002. p.22.

\subsubsection{A comunicação nas classes populares}

Quando avalia qualidade das marcas, o consumidor em geral se baseia em resultados não só funcionais, que levam em conta, por exemplo, durabilidade e eficiência do produto, como também emocionais, como prazer, reconhecimento e inclusão. Nesse aspecto, para a classe de baixa renda, a propaganda e sua linguagem desempenham papel de importância singular e precisam estar atentas às aspirações desse grupo. 
Este consumidor quer se sentir incluído na sociedade de consumo e se ver retratado com dignidade e pertinência na propaganda. Para falar com este consumidor na propaganda é preciso entender o seu estilo de vida, a simplicidade das suas estratégias de felicidade e a diferença entre o discurso do poder (material) e o discurso de viver (ALMAP/BBDO, 1996, p.4). Tais aspirações acabam por exigir que se definam conceitos de comunicação bem específicos:

As zonas de encontro do consumidor emergente com a propaganda parecem ser, sobretudo:

- a mensagem direta e simples, de preferência a palavra encenada, lembrando sempre que para este consumidor há uma grande distância entre a concretude das coisas e o vazio das palavras.

- a zona do sonho, mantendo os limites bem definidos com a realidade

- o retrato da vida, do cotidiano, vivido com alegria e criatividade, evitando-se trabalhar o aspecto aspiracional através do vetor de ascensão social. O aspiracional faz mais sentido no contexto das relações humanas, familiares e dos momentos de lazer (ALMAP/BBDO, 1996, p.5).

De fato, para se chegar a uma comunicação efetiva, é preciso considerar uma série de fatores que, segundo a Data Popular Pesquisa e Consultoria ${ }^{7}$ (2004) começam pelos valores e vão acabar na estética, passando pelo modo de agir, barreiras de acesso e estilo, como analisado a seguir:

a-) Os valores do público de baixa renda estão associados a comportamentos mais conservadores focados em união familiar, dever, sorte, fé, honra, justiça e respeito. A decisão de se usar o conceito do aspiracional na comunicação requer avaliação delicada, pois "nem sempre os consumidores se identificam com os valores implícitos em certos comerciais" (DATA POPULAR, 2004, p.6).

b-) O modo de agir das classes populares está diretamente relacionado ao contato face a face - o consumidor dessa camada tem o hábito de socializar informações sobre consumo e oportunidades de compra - e a comunicação pode, com isso, aproveitar-se do conceito de inclusão, de pertencimento ao grupo.

\footnotetext{
${ }^{7}$ Trabalho sobre Comunicação Popular apresentado no seminário GVcev "Conhecendo o Consumidor de Baixa Renda" em 17 jun. 2004.
} 
c-) As barreiras simbólicas de acesso a bens e serviços ensejam oportunidade inestimável para o trabalho de comunicação junto a esse segmento de público. No ponto de venda, por exemplo, a observação do cliente por funcionários muito próximos , o lacre nas bolsas, as portas giratórias e a exigência de comprovantes de renda, de residência e da carteira de identidade são indicadores de desconfiança que os lojistas teriam da falta de idoneidade do consumidor. Essa sensação, em parte, é justificada por sua baixa auto-estima. De forma geral, é um aspecto que pode receber contribuição forte das ações de comunicação.

d-) A cultura popular tem um estilo próprio, expresso pelo exagero, extravagância e fartura, principalmente quando se observa a exposição de produtos no ponto de venda. "A comunicação para classes populares pode se beneficiar da fartura como um estilo que também está presente na casa, na comida, na geladeira” (DATA POPULAR, 2004, p.25).

e-) A estética popular é um tanto complexa à medida que trabalha com a reinvenção de formas, cores e texturas.

\subsubsection{O perfil da mulher de baixa renda e seu comportamento de compra}

Apesar de não representar o público prioritário desse estudo, as mulheres de baixa renda desempenham papel de destaque no cenário de consumo desse grupo da população, portanto, alguns traços do seu perfil merecem ser comentados.

Segundo o BCG (2002), as mulheres são importantes agentes na hora de poupar recursos, pois cabe a elas economizar com as sobras resultantes das compras diárias ou com os pequenos rendimentos de atividades extras que conseguem. Por não contarem com a ajuda de empregadas em casa, elas acabam sendo usuárias diretas dos produtos e, por isso, são as grandes responsáveis pela tomada de decisão nas compras.

Pesquisa da agência de propaganda Ogilvy (2002) sobre hábitos de grupos de consumidores, citada pelo Jornal da Tarde (2002), destaca algumas razões da importância dessa categoria de consumidora:

O interesse nas mulheres das classes C, D e E está no fato de elas responderem por $40 \%$ do consumo no País. São as mais abertas às novidades e constituem o mercado potencial de vários lançamentos, podendo até fazer crescer as vendas de marcas tradicionais. 
O mencionado levantamento ainda retrata que a consumidora de baixa renda dá alta prioridade à educação e ao conforto dos filhos, considerados para a maioria delas o centro da família, independentemente dos outros entes, que ficam em segundo plano. A religião é destacada como a dimensão capaz de aliviar suas dores e conflitos diários e a instituição que freqüenta configura-se como o local onde se considera respeitada e importante.

Apesar de parecer um grupo homogêneo, o segmento de mulheres das classes populares, se observado mais detalhadamente, ainda pode ser subdividido para melhor compreensão. Estudo do Ibope Solution (2003) caracterizou seis diferentes grupos, conforme os valores e as atitudes consideradas comuns:

- o primeiro é o grupo do "eu me amo" ( $26 \%$ da amostra), formado predominantemente por mulheres entre 25 e 34 anos, que esbanjam auto-estima e vaidade e que não têm medo de expressar seu desejo pelo novo para serem aceitas socialmente; a busca pelo prazer sem culpa, o gosto pelo vestir-se bem e pelas novidades está presente nesse grupo, que também adora testar marcas e produtos.

- o segundo maior ( $23 \%$ da amostra) é o chamado de "eu acredito", por ser formado por mulheres com forte senso de harmonia, aceitação social e estabilidade, que se integram à rede de solidariedade e valorizam sua vizinhança e sua casa; trata-se de mulheres vaidosas que agem por impulso na hora de gastar.

- o terceiro maior ( $21 \%$ da amostra) é formado fundamentalmente por mulheres acima de 35 anos, casadas, responsáveis pelo sustento da família; é o grupo denominado por "eu sobrevivo" e sua maior preocupação é o crescimento e o sucesso profissional dos filhos, a ponto de não valorizarem o cuidado com seu próprio corpo e externarem baixa auto-estima e otimismo.

- o quarto ( $14 \%$ da amostra), conhecido por “eu vou conseguir", é constituído na sua maioria por mulheres entre 18 e 24 anos, direcionadas para o sucesso profissional, integração e aceitação social; o estudo é um dos principais objetivos por serem jovens e por valorizarem o conhecimento e a leitura.

- o quinto ( $10 \%$ da amostra) é o grupo do "eu não aceito", formado por mulheres insatisfeitas e sem esperança da vida, que desconfiam das instituições e da própria família; por 
conta da desilusão, agem com inconseqüência e por impulso com o dinheiro e com a forma como administram seus relacionamentos.

- o último grupamento ( $6 \%$ da amostra) é o das mulheres que não se encaixam em nenhum dos anteriores.

O referido estudo ainda aponta que $29 \%$ das mulheres de classe C contam com um certo potencial de mobilidade social, isto é, apresentam atitudes que as predispõem a comportamentos favoráveis à ascensão social, como escolaridade, autoconfiança, crença na capacidade de mudança. Os grupos com maior potencial de ascensão são o "eu me amo", o "eu vou conseguir" e o "eu acredito". O perfil das mulheres que os integram passa por hábitos pessoais que abrangem a plena aceitação da sensualidade, o culto do corpo e da boa aparência, a satisfação com a vida e o otimismo em relação ao futuro. Do ponto de vista econômico, trabalham mais fora de casa, acham que estão evoluindo, têm renda mensal familiar mais alta que as demais e fazem uso de mais produtos financeiros. Com relação aos seus hábitos de consumo, são auto-indulgentes, adquirem uma gama maior de produtos de primeira necessidade, buscam bens mais tecnológicos, tendem a consumir mais artigos supérfluos, valorizam a qualidade e são fiéis às marcas que gostam.

Uma peculiaridade da mulher de classe C, contudo, está presente nos seus hábitos diários de consumo: a lista de compras. Apesar de ser um guia para a aquisição dos produtos, sua existência não é fator restritivo para a aquisição de itens fora dela. É como indica a pesquisa do BCG (2002, p.16):

Cerca de metade das consumidoras faz sua lista por escrito (44\%) e $40 \%$ delas a têm na cabeça. Mais do que garantir que nenhum item será esquecido, a lista de compras tem a função de organizar a pesquisa de preço, realizada sistematicamente por $58 \%$ das consumidoras, através da consulta a folhetos de ofertas e anúncios (60\% das consumidoras) ou visitas aos pontos de venda (33\%). A pesquisa de preço garante reduções de até $12 \%$ nos gastos mensais com alimentação, higiene e limpeza. Nas listas de compras, o índice de presença de produtos supérfluos é de apenas 42\%. [...] A existência de uma lista, porém, não inibe a compra de itens não programados. Se sobrar dinheiro, 50\% das mulheres compram mais que o programado. Se ela estiver acompanhada do marido e dos filhos, esse percentual pode atingir $61 \%$; a compra excedente inclui, majoritariamente, itens considerados supérfluos, numa nítida ansiedade de proporcionar satisfação e prazer à família. Curioso é verificar que se 
a mulher estiver acompanhada de terceiros - que não sua família nuclear direta (amigas ou principalmente vizinhas) - então 63\% delas excederá a lista de compras (uma diferença significativa em comparação com o índice de 50\% das mulheres que excedem a lista quando estão sozinhas). Nesta instância, os itens adicionalmente comprados incluirão produtos top de linha que normalmente são seriam adquiridos, numa demonstração clara de imposição de prestigio e status.

No tocante às marcas, as mulheres das classes de baixa renda também apresentam comportamento específico e digno de nota. Pesquisa da agência de propaganda Ogilvy (2002) sobre hábitos de grupos de consumidores, citada pelo Jornal da Tarde, mostra que mulheres das classes $\mathrm{C}$ e D valorizam as marcas de produtos mais conhecidas, priorizando os de menor valor, isto é, aqueles que se encontram em promoção. No entanto, para mostrar às visitas de final de semana um determinado status e buscando a elevação da auto-estima, procuram ter em casa produtos de marca reconhecida.

Um quadro que pode resumir o que pensam as donas de casa da classe $C$, no que diz respeito a comportamento de compra, é apresentado pelo Latin Panel (2002, p.81) e reproduzido abaixo:

\footnotetext{
91\% procuram produtos em promoção;

$88 \%$ comparam preço antes de escolher a marca;

$82 \%$ gosta de experimentar novas marcas;

$78 \%$ limitam-se ao orçamento na compra de alimentos;

$67 \%$ concordam que preço é o fator mais importante;

$49 \%$ decidem as marcas antes de sair às compras.
}

\subsubsection{Escolha dos canais de compra}

Segundo pesquisa do Latin Panel (2002), o fator primordial na escolha do local da compra para o consumidor das classes populares coincide com o das classes mais elevadas, qual seja, a proximidade do estabelecimento com a casa ou o endereço de trabalho, e corresponde a $52 \%$ dos respondentes de todas as classes entrevistadas. O segundo motivo para aquele consumidor freqüentar uma loja é a existência de várias promoções, segundo $46 \%$ dos entrevistados da classe C e 43\% das classes D e E. O terceiro são os preços mais baixos, apontado por $41 \%$ dos entrevistados da classe C e $42 \%$ nas classes D e E. Finalmente, o 
quarto é a variedade de produtos, a exigência de boa qualidade e atendimento, que aparecem com $34 \%$ da preferência dos respondentes das classes D e E.

Os resultados do estudo do BCG (2002) para o consumidor da classe C apontam na mesma direção, apesar de não serem exatamente os mesmos. Dois são os fatores mais importantes que esse consumidor leva em conta para decidir qual canal de compra utilizar: a distância ao ponto de venda e o preço. $\mathrm{O}$ fato de não disporem de transporte próprio, aliado à estabilidade de preços, leva aproximadamente $40 \%$ das compradoras desse grupo a fazerem as compras nas cercanias da sua residência, a pé, em detrimento dos hipermercados. Isso provocou o aumento das compras de reposição, com preferência pelas padarias (82\%), feiras livres (71\%), açougues (67\%) e mercadinhos (63\%) em contraposição às compras de abastecimento, com $90 \%$ de preferência pelos supermercados.

Ao que tudo indica, os hipermercados parecem substituir as lojas de departamento, sendo usados mais nas compras de bazar que nas de mercearia. Além disso, assumem o papel de local de lazer para a família nos finais de semana. 


\section{PRESERVATIVO - PRODUTO E MERCADO}

\subsection{UM POUCO DE HISTÓRIA}

Um pouco de história sobre o produto que se constitui no objeto deste estudo torna seu conteúdo mais consistente. Conhecer alguns aspectos sobre origens e usos do preservativo pode contribuir para um melhor entendimento dos hábitos de uso e consumo do produto.

Conforme a empresa Johnson \& Johnson (2003), não é conhecida com precisão uma data que marque a origem do uso do preservativo. Teria sido encontrado em 1850 a.C. um papiro contendo uma prescrição médica do que seria o primeiro contraceptivo da história, indicando o uso de um pedaço de pano impregnado de uma pasta de excremento de crocodilo e mel. O pano deveria ser colocado na vagina, fazendo barreira para o pênis, impedindo, assim, a entrada do esperma na relação sexual. Após esse episódio, diversos outros objetos foram usados como contraceptivo ao longo da história, caso das vesículas de cabra, do meio limão, dos intestinos de carneiro, das sementes de vagem e dos pedaços de linho, seda e couro. Gravuras e desenhos do Antigo Egito (1350 a 1250 a.C.), evidenciam o uso de envoltórios feitos de tripas de animais no pênis de homens, à semelhança dos preservativos atuais e revelam que os romanos também eram conhecedores do método.

A empresa mencionada ainda cita, como parte de uma história mais recente, uma publicação de 1564 do anatomista italiano Gabriel Fallopius (1523-1563) com referências mais seguras sobre o dispositivo, recomendando o uso de um saquinho de linho amarrado com um laço para uso contra doenças venéreas. A aplicação teria sido testada em 1.100 homens, com absoluto sucesso, segundo seu próprio relato, não tendo qualquer um deles sido infectado. Passado um século após o trabalho de Fallopius, um médico inglês, alarmado com o número de filhos legítimos do rei Carlos II da Inglaterra (1630-1685), resolveu criar para Sua Majestade um protetor feito de tripa de animais para prevenir o nascimento de filhos resultantes de aventuras reais. O médico atendia por doutor Condom e, em sua homenagem, a designação "condom" passou a ser usada para referenciar, no idioma inglês, o preservativo. Formalmente, a palavra "condom" apareceu impressa pela primeira vez em 1706, na Inglaterra, em um artigo a respeito de novos inventos para a cura de doenças venéreas. A definição para preservativo, constante em dicionário de expressões vulgares, publicado em 1785, em Londres, apontava para "tripa seca de ovelha, vestida por homens no ato sexual, para prevenir doenças venéreas". 
Com as novas descobertas, por volta de 1870, surgiu o preservativo de borracha, extremamente grosso e caro. Devido ao preço, após o uso, era lavado e reutilizado várias vezes e só descartado quando a borracha arrebentava.

Data de 1901 o primeiro preservativo com reservatório na ponta, lançado nos Estados Unidos. Com a evolução tecnológica e a invenção do processo de vulcanização em 1939, o produto se tornou mais fino e elástico, permitindo maior conforto ao usuário.

\subsection{O PRODUTO}

Conforme a Johnson \& Johnson (2003), o preservativo é basicamente constituído por uma matéria-prima chamada látex, borracha natural extraída da seringueira, árvore nativa do Brasil. Além dela, outros ingredientes químicos são adicionados, para conferir maior resistência à borracha.

O processo produtivo consiste na imersão de moldes de vidro em tanques contendo látex e, na seqüência, sua secagem e lixiviação, processo de lavagem do filme de borracha. Por meio de jato d'água, o produto é retirado dos moldes, recebe talco e passa por secadoras para eliminação da unidade.

O produto é submetido a diversos testes de qualidade durante e após o processo produtivo, em que são avaliadas características dimensionais como comprimento, largura e espessura além de características físicas, como a tensão de ruptura e alongamento e a pressão e volume de estouro. Um dos testes mais importantes é o de vazamento, que verifica a existência de furos no produto e se dá de forma eletrônica. Uma vez aprovado nesse teste, o preservativo é enrolado e encaminhado para a fase de lubrificação e selagem, na qual recebe um envoltório que garante a manutenção das suas características e propriedades até o fim da sua vida útil. Esse envoltório também passa por um teste de integridade. O acondicionamento é a última fase e se dá em embalagens de 3 ou 6 unidades.

Foram consultados os sites de outros fabricantes para averiguação do processo produtivo e a conclusão é a de que as variações são mínimas entre um e outro. Os produtores de maior participação no mercado são: Johnson \& Johnson, INAL - Indústria Nacional de Artefatos de Látex Ltda., Fábrica de Artefatos de Látex Blowtex Ltda., Blausiegel e DTK. 
Informações sobre participação de mercado são confidenciais e, portanto, de difícil acesso. No entanto, estimativas de executivos do setor consideram que a liderança em vendas por fabricante é ocupada pela Johnson \& Johnson, com aproximadamente 35\% do total. A segunda colocada seria a INAL e teria algo próximo a $17 \%$ de participação. Os demais fabricantes ocupariam as posições restantes, com participações bem menores.

A Johnson \& Johnson comercializa toda sua linha de produto sob a marca Jontex, da mesma forma que a Blausiegel, que utiliza a marca Preserv. A INAL está presente com quatro marcas distintas: Olla, Lovetex, Microtex e Falcon. A Blowtex trabalha com a marca Blowtex propriamente dita e a Powersex. E a DTK é a importadora da linha Prudence.

O Datafolha (2003), na pesquisa “Top of Mind 2003”, confirma o nível de marketshare da líder Johnson \& Johnson e também a primeira colocação para a Jontex em lembrança de marca na categoria preservativo, com $27 \%$ das respostas. A Olla ocupa a segunda posição nesse quesito com $6 \%$.

Nessa indústria, há marcas posicionadas nos segmentos premium e low-end, conforme o nível de investimento em imagem e o preço praticado. As marcas Jontex, Olla e Preserv estão posicionadas no topo, com preços acima das demais e esforço de distribuição localizado nos estados de maior poder aquisitivo como São Paulo, Rio de Janeiro e da região Sul.

Lovetex e Microtex praticam preços mais baixos e posicionam-se no segmento lowend.

Há outras marcas de menor expressão, que têm uma abrangência mais regional, como é o caso da Eros, presente na região Nordeste e da Prosex, com foco de comercialização no Rio de Janeiro, cujo público-alvo é o de menor poder aquisitivo.

De maneira geral, os preservativos são vendidos no mercado sob duas formas de apresentação: em embalagens com três ou seis unidades. Como uma das estratégias de marketing dos fabricantes é a segmentação do seu público-alvo, a linha de produtos procura ser diversificada de forma a satisfazer as necessidades do consumidor. Assim, o que se encontra no mercado é uma segmentação que obedece aos seguintes critérios:

- preservativos lisos e lubrificados: são os mais comuns, não apresentando qualquer outra atratividade para o consumidor; correspondem a cerca de $80 \%$ do mercado. 
- preservativos texturizados: para atender o consumidor que busca mais prazer durante o ato sexual, dado o maior estímulo gerado entre os órgãos genitais; também são lubrificados.

- preservativos aromatizados: para os usuários que buscam prazer por meio do sexo oral e que apreciam o sabor como ingrediente; também são lubrificados.

- preservativos de espessura mais fina: para quem julga que o produto, por sua natureza, diminui a sensibilidade na relação sexual; também são lubrificados.

- preservativos anatômicos: para aqueles que valorizam o maior conforto proporcionado pelo formato do produto.

- preservativos de tamanhos diferenciados: para quem busca maior conforto em preservativos com tamanhos maiores; também são lubrificados.

- preservativos não lubrificados: para quem é alérgico aos lubrificantes ou para exames ultra-sonográficos da próstata em laboratórios ou hospitais.

A embalagem, por sua vez, cumpre adequadamente seu papel como atributo de produto. Isso se dá de duas formas: a primeira, por meio da função de proteção física oferecida ao produto, que garante suas propriedades originais de fábrica, até que ele chegue às mãos do consumidor; a segunda, por meio da função de comunicação, que transmite ao consumidor imagem de marca, instruções técnicas, informações institucionais e mensagens promocionais. No cumprimento dessa segunda função, é comum, na arte da embalagem, a presença dos seguintes elementos: combinação de cores e tipologia que dão destaque à marca e ao modelo (segmento de produto); impressão clara das especificações do produto, como dimensões e quantidades; selos de certificação de qualidade do produto dos órgãos competentes; recomendações de uso e de abertura da embalagem; dados do fabricante e do serviço de apoio ao consumidor. Em geral, os produtos encontrados no mercado usam embalagem tipo flow-pack com 3 ou 6 unidades, sendo o preservativo embalado em envelopes individuais.

Com relação à distribuição, o preservativo é disponibilizado ao consumidor basicamente por meio de dois canais: o canal alimentar, constituído dos super e hiper mercados e o canal farmacêutico, formado pelas farmácias. Mais recentemente, no entanto, percebeu-se uma certa difusão, ainda em escala reduzida, de máquinas de venda de 
preservativos em casas noturnas e bares da cidade de São Paulo, em algumas empresas e até mesmo na rodoviária da capital paulista.

No que diz respeito ao preço, observando as dimensões continentais do Brasil, há uma variação bastante considerável. Dependendo da praça, da marca e de outros atributos como textura, aroma, cor, são encontrados preservativos, na embalagem de 3 unidades, pelo valor que varia entre o mínimo de aproximadamente $\mathrm{R} \$ 1,00$ e o máximo de cerca de $\mathrm{R} \$ 4,50$.

\subsection{O MERCADO}

Segundo a Coordenação Nacional - DST/AIDS, órgão do Ministério da Saúde, atualmente são consumidos quase 700 milhões de preservativos por ano. Nos últimos dez anos, o crescimento do mercado foi de quase 15 vezes e a participação da distribuição pública vem aumentando representativamente, em um esforço crescente do governo de combater as doenças no país e contribuir para a aplicação de métodos contraceptivos pelas famílias. A figura 9 ilustra essa informação.

Figura 9 - Consumo de preservativos no país

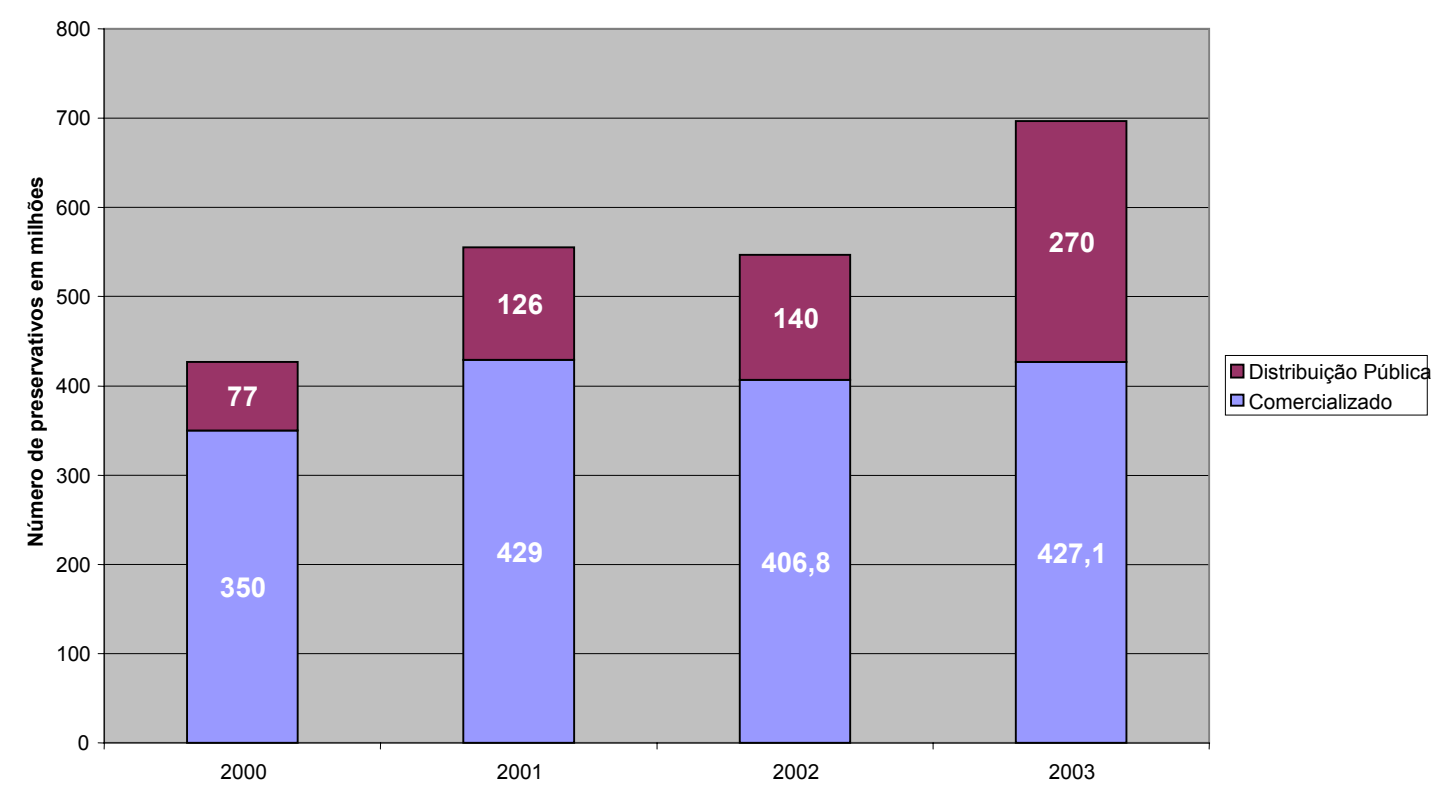

Fonte: Adaptado de MS/SPS/CN-DST/Aids - O perfil da Aids no Brasil e metas do governo para o controle da epidemia. Disponível em: <http://www.aids.gov.br/final/biblioteca/metas/metas.pdf>. Acesso em: 18 nov. 2003. 
Com o intuito de impulsionar o aumento do consumo, algumas políticas fiscais vêm sendo implementadas ao longo desse período, como a redução do IPI em 1994, do ICM em 1996 e com a isenção de ICMS em 1997.

O governo tem uma meta de aumentar o volume de preservativos disponibilizados em todo país para 1,2 bilhão / ano nos próximos anos, por meio de algumas políticas que incluem:

- redução de impostos, ampliação dos pontos de venda e distribuição e definição de preço máximo ao consumidor, visando à implantação do preservativo social.

- distribuição de preservativos na rede pública de educação, em uma parceria entre os Ministérios da Saúde e da Educação.

- aumento do volume de compra e de distribuição de preservativos pelo setor público.

O governo também lança mão de campanhas de massa com o intuito de promover o uso mais intenso do preservativo. Segundo o Ministério da Saúde, "a definição das abordagens em comunicação de massa parte da análise das tendências da epidemia e da identificação de populações mais vulneráveis às quais devem ser dirigidas as mensagens”. São mensagens com foco na segurança que o uso consistente do preservativo traz para a prevenção do HIV / Aids e de outras doenças sexualmente transmissíveis, fazendo uso de abordagens temáticas como: travestis, carnaval, profissionais do sexo, homens que fazem sexo com homens, caminhoneiros, a própria camisinha, o dia mundial de luta contra a Aids, dentre outros.

Um dos temas com grande repercussão e que, segundo o mesmo Ministério da Saúde, é o mais lembrado pela população, é o que aborda o carnaval. Historicamente, o Ministério da Saúde desenvolve campanha de comunicação de massa e promove distribuição extra de preservativos para o período das festas, o que já se transformou em ação esperada por parte da própria população.

\subsection{BARREIRAS E PRECONCEITOS}

Muitas barreiras ainda precisam ser transpostas para o uso do preservativo se tornar, naturalmente, parte do rito sexual do brasileiro. Uma das posições mais contundentes contra o uso desse dispositivo vem de uma das mais tradicionais instituições do país, a igreja católica. 
Apesar de reconhecer que hoje, no cenário internacional, o Brasil se apresenta como um modelo a ser seguido na luta contra a propagação da Aids, a ala mais conservadora da igreja avalia que as campanhas governamentais concentram-se no preservativo como a única garantia do sexo seguro. O Cardeal Dom Eugênio de Araújo Sales (2002), Arcebispo Emérito da Arquidiocese do Rio de Janeiro, figura expoente dessa ala, argumenta:

\footnotetext{
Essa discriminação, preferindo-a ("a camisinha”) parece muito estranha, principalmente por estar em jogo a vida humana. Diante da gravidade da epidemia, é incompreensível que organismos destinados a preservar a saúde, em suas informações, omitam ou deixem em semi-obscuridade a abstinência sexual ou, pelo menos, o parceiro único. Não nos esqueçamos de que a promiscuidade sexual é um dos fatores mais importantes na difusão desse vírus.[...] Toda uma mentalidade pró-liberdade irrestrita do instinto sexual inibe a proclamação de outros meios capazes de impedir, com segurança, o contágio da AIDS. O preservativo, chamado "sexo seguro", na verdade nem sempre o é. Todas as vezes que se rompe o látex, usado por alguém infectado, uma vida humana fica exposta. E o responsável por esse desastre escapa à punição.
}

Por outro lado, uma corrente mais progressista da igreja católica, começa a se manifestar a favor do preservativo como meio para prevenção da Aids. Um dos porta-vozes de maior representatividade dessa ala é o Padre Valeriano Paitoni, importante parceiro do Ministério da Saúde e um dos pioneiros na luta contra a doença. Para a Coordenação Nacional de Aids, do referido Ministério da Saúde (2000)

\footnotetext{
há um distanciamento entre o discurso da cúpula da CNBB (ala conservadora) e a realidade dos setores que trabalham com projetos de assistência, apoio e prevenção feitos no país pela igreja católica. Prova disso é o uso da denominação 'aidéticos' para as pessoas vivendo com AIDS, termo que denota preconceito e mostra que os dirigentes da igreja não estão familiarizados com a epidemia[...].
}

Em vista de posições radicais de uma instituição tão influente como a igreja católica, o combate à Aids ainda tem um longo caminho a percorrer. Mas entidades mais esclarecidas, como algumas alas da própria igreja católica, bem como determinadas ONGs, conscientes da prova científica de eficácia do preservativo na prevenção da doença, têm se mantido perseverantes com ações de distribuição gratuita do produto e assistência às vítimas da epidemia. 


\section{COMPORTAMENTO DO BRASILEIRO EM RELAÇÃO AO PRESERVATIVO}

A já mencionada pesquisa MS/IBOPE 2003 sobre a vida sexual do brasileiro mostra que $69,2 \%$ da população é sexualmente ativa (teve relação sexual nos últimos 6 meses), o que correspondente a 85 milhões de habitantes. A maior proporção de pessoas sexualmente ativas encontra-se na região Sul (76,5\%), seguida pelas regiões Norte e Centro-Oeste $(71,4 \%)$. Entre os homens, $76,2 \%$ são sexualmente ativos contra $62,7 \%$ das mulheres. Na análise por faixa etária, a grande maioria (91,3\%) das pessoas entre 30 e 39 anos são sexualmente ativas; em seguida, destacam-se os $85,2 \%$ da faixa entre 40 e 49 anos e os $83,4 \%$ dos indivíduos entre 20 e 29 anos. Esses dados são melhor observados no gráfico 15 .

Focando exclusivamente a população sexualmente ativa, a referida pesquisa mostra alguns destaques. Quanto ao sexo, 53,1\% são homens e 46,9\% são mulheres. Por idade, $28,5 \%$ estão entre 20 e 29 anos, $27,2 \%$ entre 30 e 39 anos e 20,2\% entre 40 e 49 anos. Quanto maior o grau de instrução, menor a proporção de pessoas sexualmente ativas; são $36,1 \%$ das pessoas sexualmente ativas com nível até a $4^{\mathrm{a}}$ série do ensino fundamental, 34,5\% com mais do que o ensino médio e cerca de $29 \%$ com ensino entre $5^{\mathrm{a}}$ e $8^{\mathrm{a}}$ série.

Chamando atenção para o foco de interesse desse estudo, a pesquisa mencionada aponta que, quanto maior a classe econômica, menor a proporção de pessoas sexualmente ativas; quase $50 \%$ faz parte da classe $D / E$, cerca de $35 \%$ pertence à classe C e algo próximo a 17\% é da classe A / B. O gráfico 16 ilustra essas informações com mais clareza.

Ainda no tocante à população sexualmente ativa, a referida pesquisa mostra, em 2003, um número médio de relações sexuais por mês de 10,2, sendo a freqüência dos homens $27,3 \%$ maior que a das mulheres. Indivíduos na faixa etária de 20 a 29 anos apresentam média de 12,2 relações sexuais por mês; de 30 a 39 anos, 11,6 relações e os de 14 a 19 anos, 8,3 relações.

É importante destacar que o número médio de relações sexuais por mês de pessoas que não usam preservativos de forma regular $(10,6)$ é $35 \%$ maior que das que usam $(7,9)$. 
Gráfico 15 - Percentual da população brasileira de 14 anos e mais, sexualmente ativa nos últimos 6 meses, por região, sexo e faixa etária

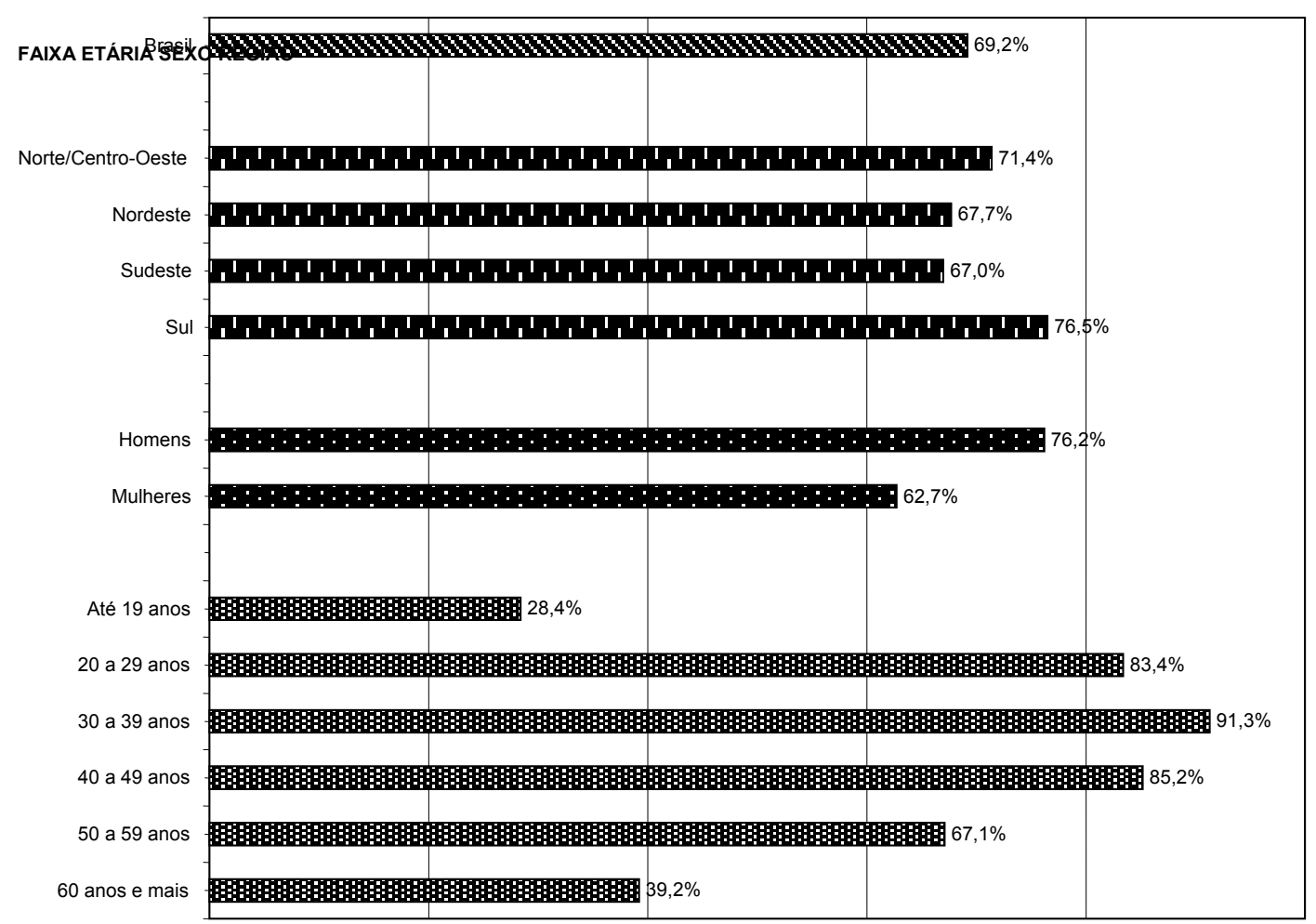

Fonte: MS/SPS/CN-DST/Aids - Comportamento da população brasileira sexualmente ativa (MS/IBOPE 2003). Disponível em: <http://aids.gov.br/final/biblioteca/ibope_2003/briefing2.doc>. Acesso em: 18 nov. 2003. 
Gráfico 16 - Distribuição da população sexualmente ativa nos últimos 6 meses, de 14 anos e mais, segundo o grau de instrução e classe econômica (\%)

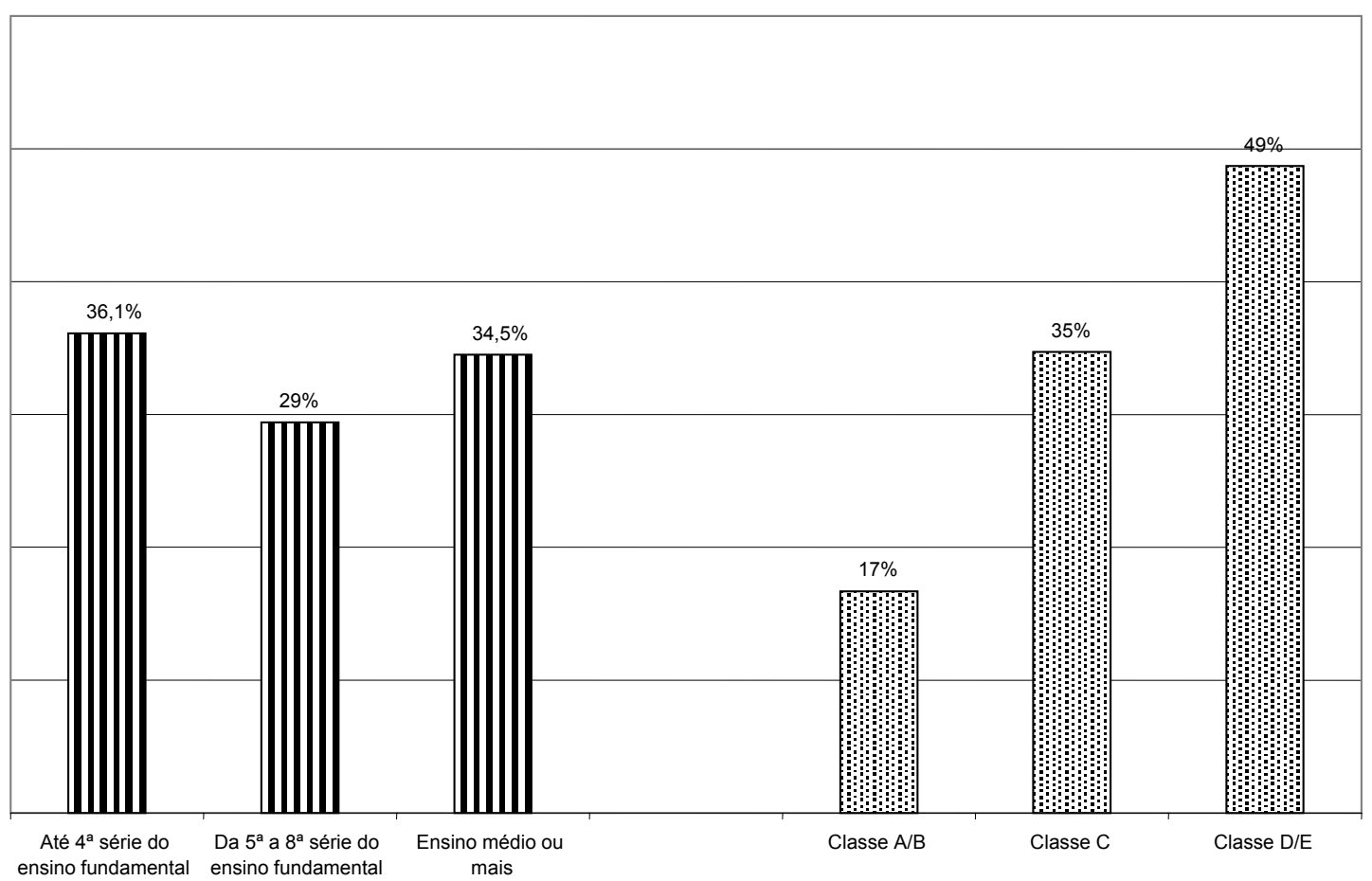

Fonte: MS/SPS/CN-DST/Aids - Comportamento da população brasileira sexualmente ativa (MS/IBOPE 2003). Disponível em: <http://aids.gov.br/final/biblioteca/ibope_2003/briefing2.doc >. Acesso em: 18 nov. 2003.

\subsection{USO DO PRESERVATIVO}

$\mathrm{Na}$ referida pesquisa MS/IBOPE 2003, são examinados a proporção de pessoas sexualmente ativas nos últimos 6 meses e que declarou o uso de camisinha com parceiros fixos ou eventuais e os motivos para usar ou não usar o preservativo. Também são identificadas eventuais diferenças, segundo variáveis sociodemográficas. A base de comparação dos resultados é outra pesquisa publicada em 2000 pelo Ministério da Saúde / CEBRAP (Centro Brasileiro de Análise e Planejamento - MS/CEBRAP 2000). Essa pesquisa indicou alguns sinais: no Brasil urbano e naquele ano, o estado conjugal (solteiro / casado) foi um preditor importante dos graus de risco de exposição maior ou menor ao HIV; o uso do preservativo não era muito diferente entre as pessoas que tinham mais de um parceiro ou apenas um; a 
proporção de uso do preservativo era bem maior nas relações eventuais que no contexto de relações com parceiros fixos e na faixa etária dos jovens de 16-25 anos.

A pesquisa MS/IBOPE 2003 descreve os padrões de uso de preservativo que combinam as variáveis uso do preservativo e tipo de vínculo com o parceiro, agrupados em duas categorias: uso consistente - que se refere a sempre ter usado nas relações sexuais dos últimos 6 meses, inclusive na última - e uso inconsistente - que está associado a nunca usar ao longo daquele período ou usar às vezes.

Os principais resultados são os seguintes:

- Com referência às práticas sexuais, $84,2 \%$ do universo pesquisado mantiveram relações sexuais exclusivamente com parceiros fixos nos últimos 6 meses; 8,2\% relacionaram-se apenas com parceiros eventuais e 7,6\% com parceiros de ambos os tipos (fixos e eventuais).

- Com relação ao uso do preservativo, de uma pesquisa para a outra, notou-se que reduziu a proporção de brasileiros sexualmente ativos e que usaram preservativo consistentemente - de 23,9\% para 14,5\% - enquanto aumentou de 64,4\% para 75\% a proporção de brasileiros em relação estável e exclusiva que não usaram preservativos.

- Percebeu-se um aumento do uso do produto nas relações com parceiros eventuais (de $64 \%$ para $82,8 \%$ ) e a permanência de níveis baixos com parceiros fixos.

Esses resultados parecem mostrar uma tendência de aumento de confiança no parceiro estável. No entanto, a redução da proporção dos que usaram o preservativo consistentemente nas últimas relações sugere a necessidade de maior tomada de consciência da população e ações principalmente governamentais de sensibilização quanto ao problema.

\subsection{MOTIVOS DE USO DO PRESERVATIVO}

Além de analisar o uso do preservativo em si, é importante compreender as razões da sua utilização ou não. Os principais pontos levantados pela referida pesquisa são:

- Mudaram as razões alegadas para não se usar o preservativo, pois diminuiu a proporção dos que argumentam usar outros contraceptivos e quase sumiram respostas do tipo "preservativo atesta traição", "não dá tempo", "não acredito que evite”, "tenho alergia", "tira o prazer”. São $5 \%$ os que relataram não ter usado porque não gostam. Os motivos para o não uso estão associados à confiança no parceiro.

- As mulheres relataram menor uso consistente de preservativos. A proporção de mulheres que não usa preservativo de forma consistente em relações estáveis $(83,8 \%)$ é maior que a dos homens (67,1\%). Fato semelhante ocorre entre os indivíduos de menor 
escolaridade, que têm até o ensino fundamental, em especial até a $4^{a}$ série.

- Os mais jovens, da faixa de 14 a 25 anos, destacam-se no grupo que mais usa preservativo na primeira relação sexual $(54,6 \%)$ e entre os que usam mais consistentemente $(28,3 \%)$. Tais proporções são pelo menos duas vezes maiores que as encontradas entre os indivíduos da faixa de 26 a 40 anos.

Tais resultados parecem confirmar que os motivos para o não uso do dispositivo estão realmente associados à confiança no parceiro e também sugerem que o fato de as mulheres terem reduzido o uso consistente do preservativo pode ser uma das razões que as tornam um dos grupos nos quais registrou-se maior evolução da epidemia, conforme comentado na seção 1.2.1.

A redução de uso do preservativo pelas mulheres é confirmada pelos relatos de executivos da Johnson \& Johnson, colhidos em visitas realizadas a essa empresa, que apontam os homens como responsáveis por 93\% das compras do item, seguido do casal e da mulher, com respectivamente apenas $5 \%$ e $2 \%$.

\subsection{ACESSO E PADRÕES DE COMPRA}

Outro aspecto importante a ser ressaltado neste estudo é a questão do acesso ao produto. A pesquisa MS/IBOPE 2003 destaca os seguintes pontos:

- Das pessoas sexualmente ativas, 46,6\% compram ou já haviam comprado preservativo pelo menos uma vez na vida, enquanto 35,6\% já receberam na rede pública de saúde. Nesses percentuais já está embutida a proporção de 19,9\%, correspondente aos que acessaram o produto das duas formas (compraram e receberam). Os que não compraram ou não receberam, isto é, não fizeram uso, somaram o percentual considerável de 37,4\%. Esses dados estão mais detalhados na figura 10.

- Uma visão mais abrangente da população que compra preservativos no Brasil pode ser obtida no quadro 6. Nota-se que a maioria dos que compram ou já compraram preservativos encontra-se na região Sudeste (46,6\%), na faixa dos 20 aos 39 anos $(65,6 \%)$, são do sexo masculino $(68,0 \%)$ e não são usuários consistentes do produto $(75,6 \%)$. Uma proporção maior de pessoas negras comprou preservativo $(55,1 \%)$ em comparação com as brancas ( $45,9 \%$ ) e o grupo de pessoas que tinha entre 5 e 12 relações mensais foi o que mais comprou nessa categoria (32,3\%). O destaque fica para a grande predominância das classes de baixa renda $(\mathrm{C} / \mathrm{D} / \mathrm{E})$ na proporção dos que já compraram $(76,6 \%)$. 
Figura 10 - Distribuição das pessoas sexualmente ativas nos últimos 6 meses, de 14 anos ou mais, que compram ou compraram preservativos e receberam ou pegaram gratuitamente na rede pública (\%) - Brasil, 2003

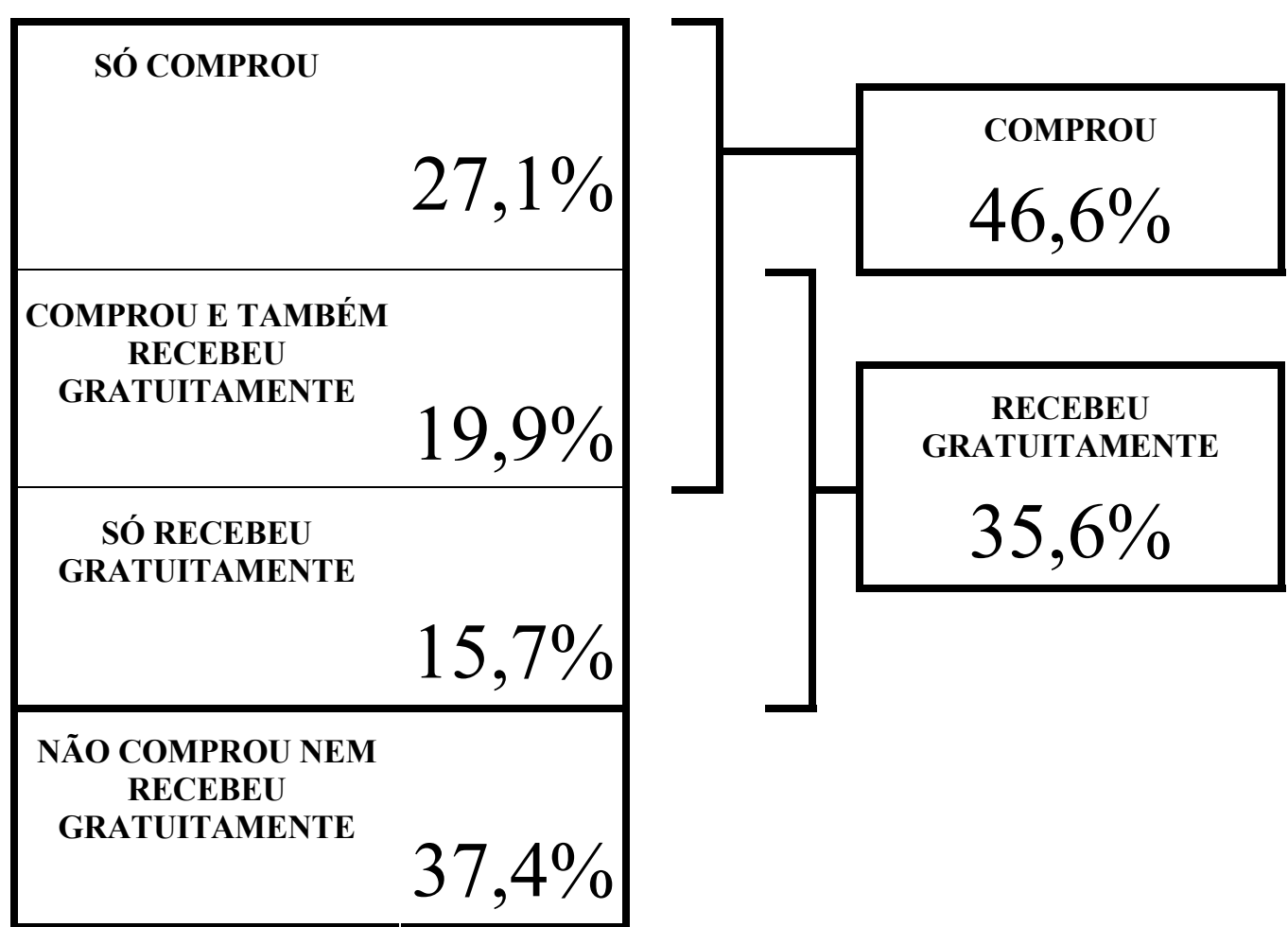

Fonte: Adaptado de MS/SPS/CN-DST/Aids - Acesso a preservativos distribuídos pela rede pública de saúde e padrão de compra de preservativo (MS/IBOPE 2003). Disponível em: < $<$ ttp://www.aids.gov.br/final/biblioteca/ ibope_2003/preservativo1.doc $>$. Acesso em: 18 nov. 2003. 
Quadro 6 - Distribuição das pessoas sexualmente ativas nos últimos 6 meses de 14 anos ou mais que compram ou já compraram preservativos, segundo região de residência, faixa de idade, sexo, cor/raça, classe econômica, grau de instrução, indicador de risco e número médio de relações por mês - Brasil, 2003

\begin{tabular}{|c|c|}
\hline & $\%$ \\
\hline Brasil & 46,6 \\
\hline $\begin{array}{l}\text { Região } \\
\text { Norte / Centro-Oeste } \\
\text { Nordeste } \\
\text { Sudeste } \\
\text { Sul }\end{array}$ & $\begin{array}{l}13,7 \\
21,4 \\
46,6 \\
18,3\end{array}$ \\
\hline $\begin{array}{l}\text { Faixa de Idade } \\
14 \text { a } 19 \text { anos } \\
20 \text { a } 29 \text { anos } \\
30 \text { a } 39 \text { anos } \\
40 \text { a } 49 \text { anos } \\
50 \text { a } 59 \text { anos } \\
60 \text { anos e mais }\end{array}$ & $\begin{array}{c}9,1 \\
36,6 \\
29,0 \\
17,3 \\
5,3 \\
2,8\end{array}$ \\
\hline $\begin{array}{l}\text { Sexo } \\
\text { Homens } \\
\text { Mulheres }\end{array}$ & $\begin{array}{l}68,0 \\
32,0\end{array}$ \\
\hline $\begin{array}{l}\text { Cor/Raça } \\
\text { Branca } \\
\text { Negra }^{8}\end{array}$ & $\begin{array}{l}44,9 \\
55,1\end{array}$ \\
\hline $\begin{array}{l}\text { Classe Econômica } \\
\text { Classe A/B } \\
\text { Classe C } \\
\text { Classe D/E }\end{array}$ & $\begin{array}{l}23,4 \\
37,4 \\
39,2\end{array}$ \\
\hline $\begin{array}{l}\text { Grau de instrução } \\
\text { Até } 4^{a} \text { série do fundamental } \\
5^{a} \text { a } 8^{a} \text { série do fundamental } \\
\text { Ensino Médio e mais }\end{array}$ & $\begin{array}{l}21,9 \\
34,8 \\
43,3\end{array}$ \\
\hline $\begin{array}{l}\text { Indicador de Risco } \\
\text { Usou sempre preservativo } \\
\text { Não usou sempre preservativo }\end{array}$ & $\begin{array}{l}24,4 \\
75,6\end{array}$ \\
\hline $\begin{array}{l}\text { Número médio de relações por mês } \\
\text { Até } 4 \\
\text { De } 5 \text { a } 12 \\
\text { Mais de } 12 \\
\text { Sem freqüência / Não opinou }\end{array}$ & $\begin{array}{l}23,9 \\
32,3 \\
25,9 \\
18,0\end{array}$ \\
\hline
\end{tabular}

Fonte: Adaptado de MS/SPS/CN-DST/Aids - Acesso a preservativos distribuídos pela rede pública de saúde e padrão de compra de preservativo (MS/IBOPE 2003). Disponível em: <http://www.aids.gov.br/final/biblioteca/ ibope_2003/preservativo1.doc>. Acesso em: 18 nov. 2003. (grifo do autor)

\footnotetext{
${ }^{8}$ Nota: (1) Negros englobam os negros, pardos e morenos.
} 
Outra leitura que pode ser feita com base na pesquisa diz respeito ao padrão de compra em cada um dos grupos de análise destacados. Assim, chama atenção a proporção das pessoas que moram no Sudeste e no Sul (50\%) e a das pessoas entre 14 e 19 anos (64\%) que compram ou já compraram preservativo algum dia, sendo esse percentual decrescente à medida que cai a faixa etária. Dentre as pessoas que não usaram preservativo sempre, 42,0\% já compraram o produto, contra uma proporção de $71,5 \%$ para o segmento de pessoas que usaram sempre. Quanto maior o número médio de relações sexuais mensais, maior a proporção de pessoas que compram ou já compraram preservativo. No que diz respeito à cor/raça, não houve diferenças significativas no padrão de compra dos negros comparado ao dos brancos. Com relação à classe econômica, dentre as pessoas pertencentes à classe $D / E$ encontra-se o menor número dos que já compraram ou compram preservativo $(37,6 \%)$, notando-se que, quanto maior a classe, maior a proporção de pessoas sexualmente ativas que comprou o produto. Essa leitura está apresentada mais claramente nos gráficos 17 e 18 .

Gráfico 17 - Proporção de pessoas sexualmente ativas que compra ou já comprou preservativos, segundo região de residência, sexo, cor/raça e faixa de idade

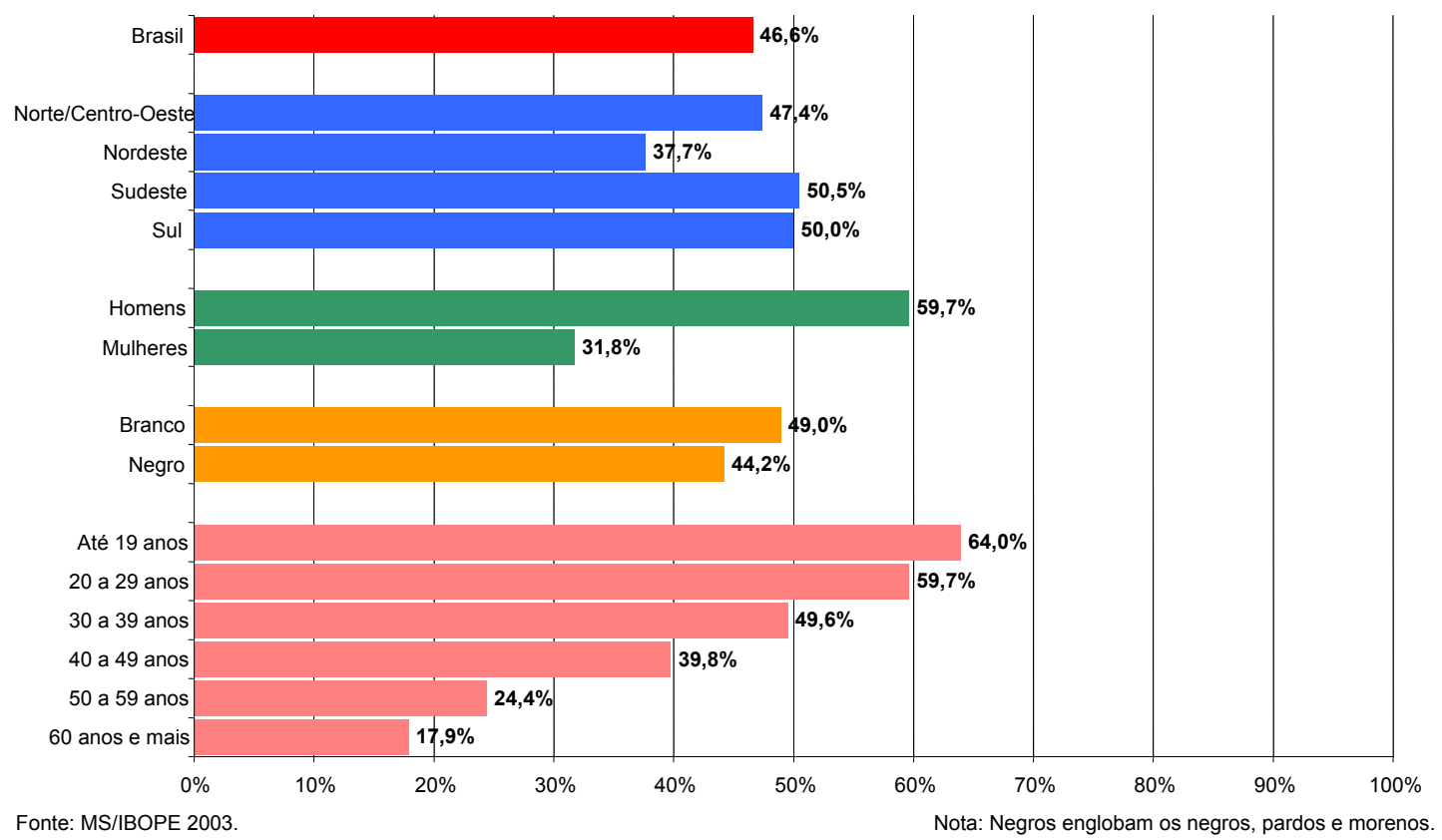

Fonte: MS/SPS/CN-DST/Aids - Acesso a preservativos distribuídos pela rede pública de saúde e padrão de compra de preservativo (MS/IBOPE 2003). Disponível em: <http://www.aids.gov.br/final/biblioteca/ibope 2003/preservativo1.doc>. Acesso em: 18 nov. 2003. 
Gráfico 18 - Proporção de pessoas sexualmente ativas que compra ou já comprou preservativos, segundo escolaridade, classe econômica, número médio de relações por mês

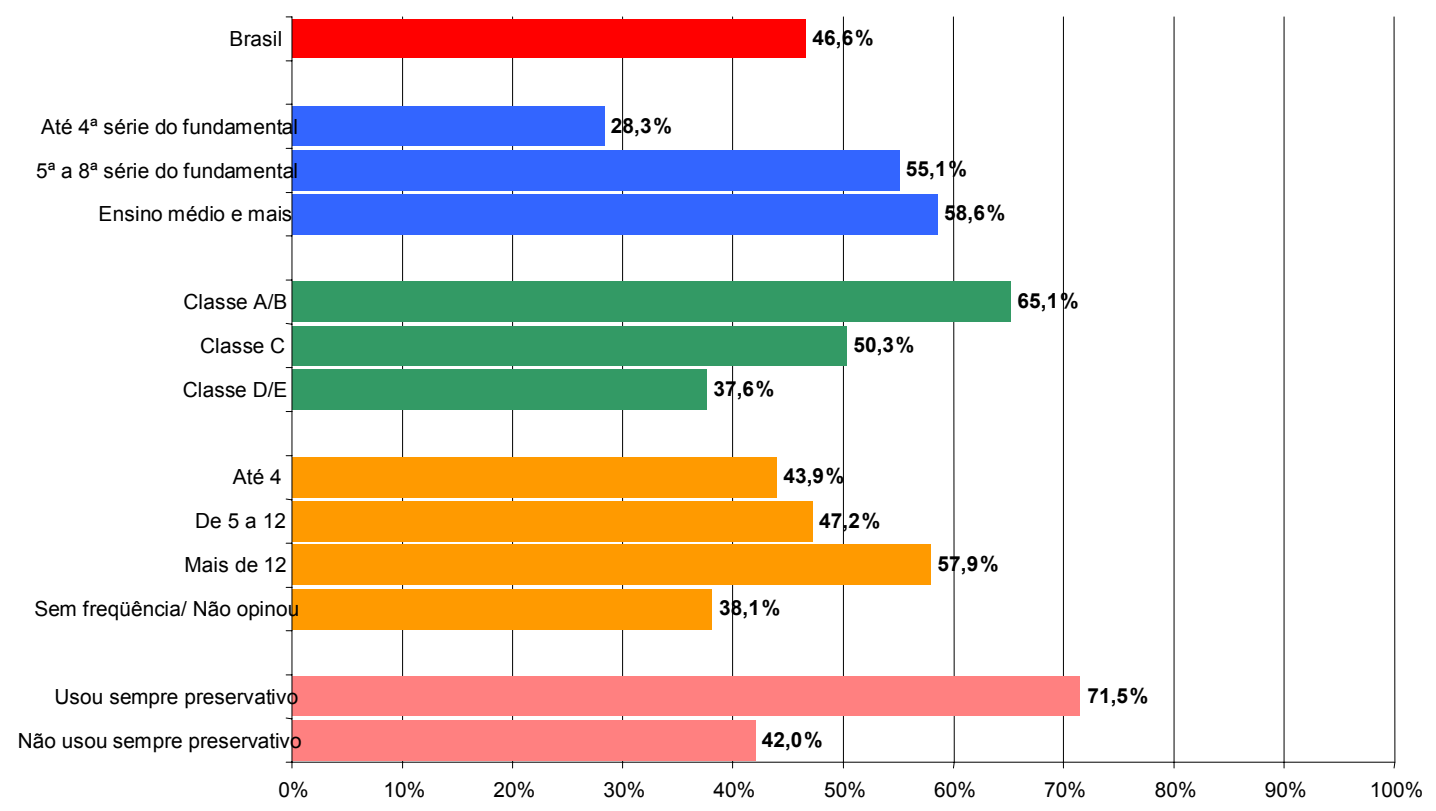

Fonte: MS/SPS/CN-DST/Aids - Acesso a preservativos distribuídos pela rede pública de saúde e padrão de compra de preservativo (MS/IBOPE 2003). Disponível em: <http://www.aids.gov.br/final/biblioteca/ibope 2003/preservativo1.doc>. Acesso em: 18 nov. 2003.

\subsection{FATORES IMPORTANTES NA DECISÃO DE COMPRA}

Extremamente relevante para este estudo foi o conjunto de atributos levantados na pesquisa e avaliados pelos entrevistados como importantes na hora da compra do preservativo.

O maior destaque fica para a marca, considerado o fator mais importante na decisão de compra do preservativo. Cerca de $49 \%$ da população sexualmente ativa a elegeram em primeiro lugar, argumentando que a marca determina e condiciona todos os outros requisitos, além de ser garantia de qualidade. Em segundo lugar na ordem de importância, ficou o conforto, indicado por cerca de $15,6 \%$ das pessoas sexualmente ativas. Em seguida, veio a lubrificação com aproximadamente $12,1 \%$ e o preço, com $10 \%$. O cheiro e o tamanho foram apontados por cerca de $2 \%$ da população sexualmente ativa e a cor/sabor, por $1,4 \%$. Esses dados estão representados no gráfico 19. 
Gráfico 19 - Distribuição do que as pessoas sexualmente ativas consideram mais importante na hora de comprar preservativos

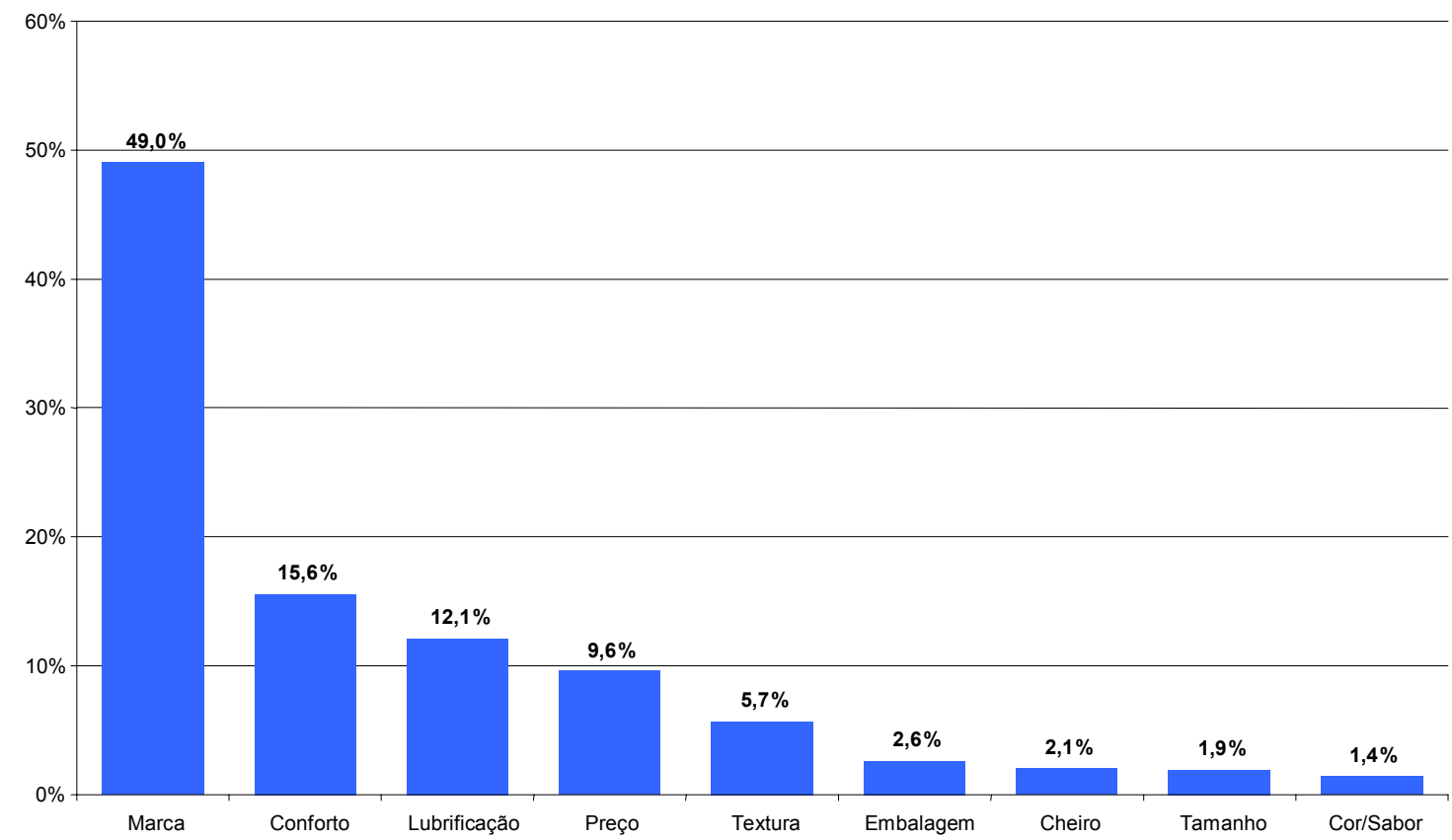

Fonte: MS/SPS/CN-DST/Aids - Acesso a preservativos distribuídos pela rede pública de saúde e padrão de compra de preservativo (MS/IBOPE 2003). Disponível em: <http://www.aids.gov.br/final/biblioteca/ibope 2003/preservativo1.doc>. Acesso em: 18 nov. 2003.

A pesquisa MS/IBOPE 2003 permitiu, mais uma vez, uma leitura por outro ângulo, mostrando a importância de cada atributo avaliada segundo região de residência, sexo, faixa etária, cor/raça, classe econômica, grau de instrução, indicador de risco e número médio mensal de relações sexuais.

A marca é o fator mais importante entre a população sexualmente ativa das regiões Norte/Centro-Oeste e Sudeste (aproximadamente 56\% das pessoas dessas regiões a escolheram), em comparação com as outras. O preço destaca-se nas regiões Nordeste e Sul (cerca de 13\% das preferências). E a lubrificação é ressaltada nas regiões Norte/Centro-Oeste (perto de 14\%), em comparação às outras regiões, como pode ser visualizado no gráfico 20.

No tocante ao sexo, de maneira geral os atributos têm a mesma importância tanto para homens como para mulheres, como pode ser observado no gráfico 21. As diferenças mais significativas ficam por conta da marca - que recebe aproximadamente $52 \%$ dos votos dos homens e $48 \%$ do das mulheres como fator mais importante - e da lubrificação, que tem cerca de $14 \%$ da preferência das mulheres contra aproximadamente $10 \%$ da dos homens. O que 
Gráfico 20 - Distribuição do que as pessoas sexualmente ativas consideram mais importante na hora de comprar preservativos, segundo a região

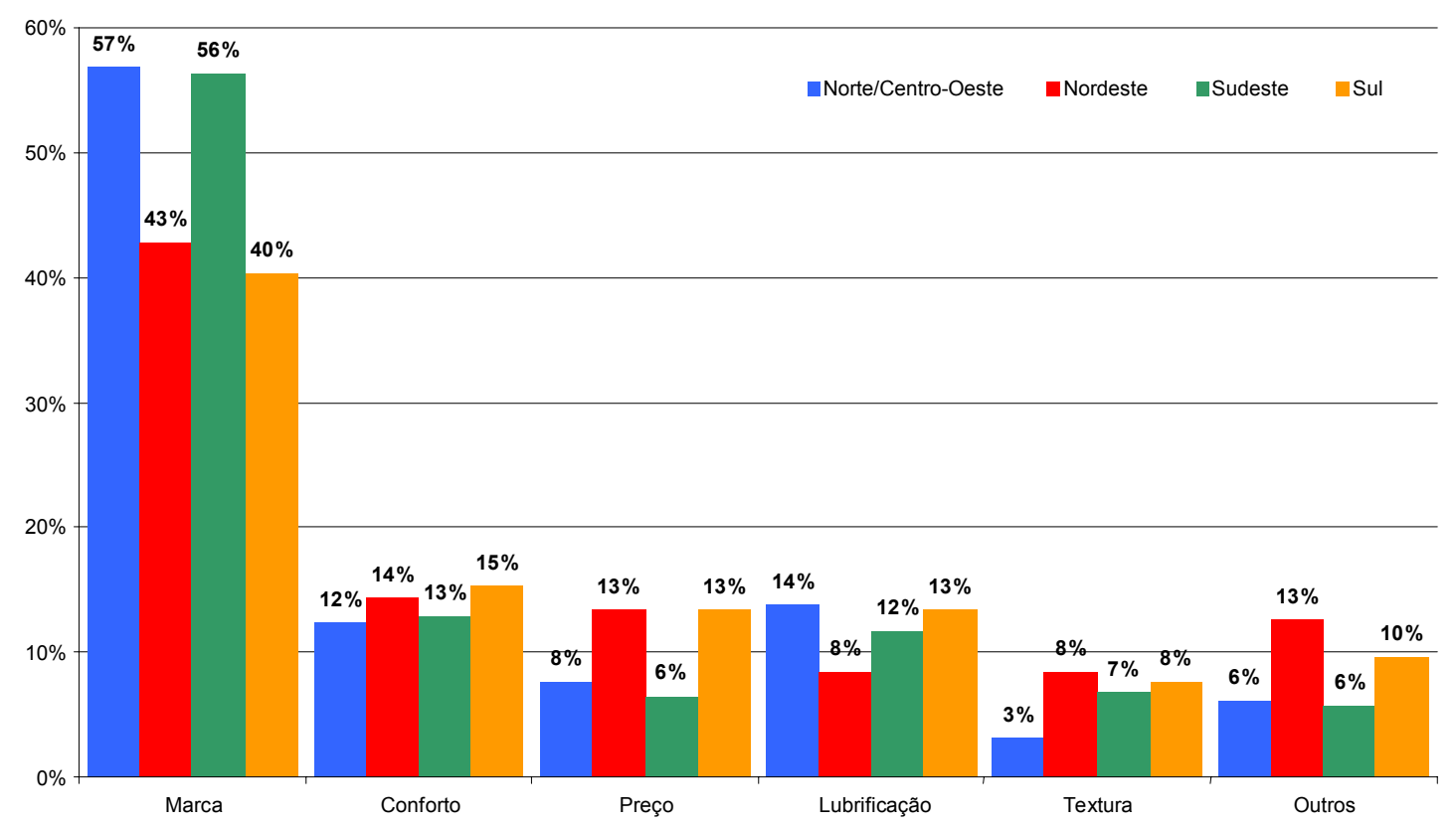

Fonte: MS/SPS/CN-DST/Aids - Acesso a preservativos distribuídos pela rede pública de saúde e padrão de compra de preservativo (MS/IBOPE 2003). Disponível em: <http://www.aids.gov.br/final/biblioteca/ibope 2003/preservativo1.doc>. Acesso em: 18 nov. 2003.

Gráfico 21 - Distribuição do que as pessoas sexualmente ativas consideram mais importante na hora de comprar preservativos, segundo o sexo

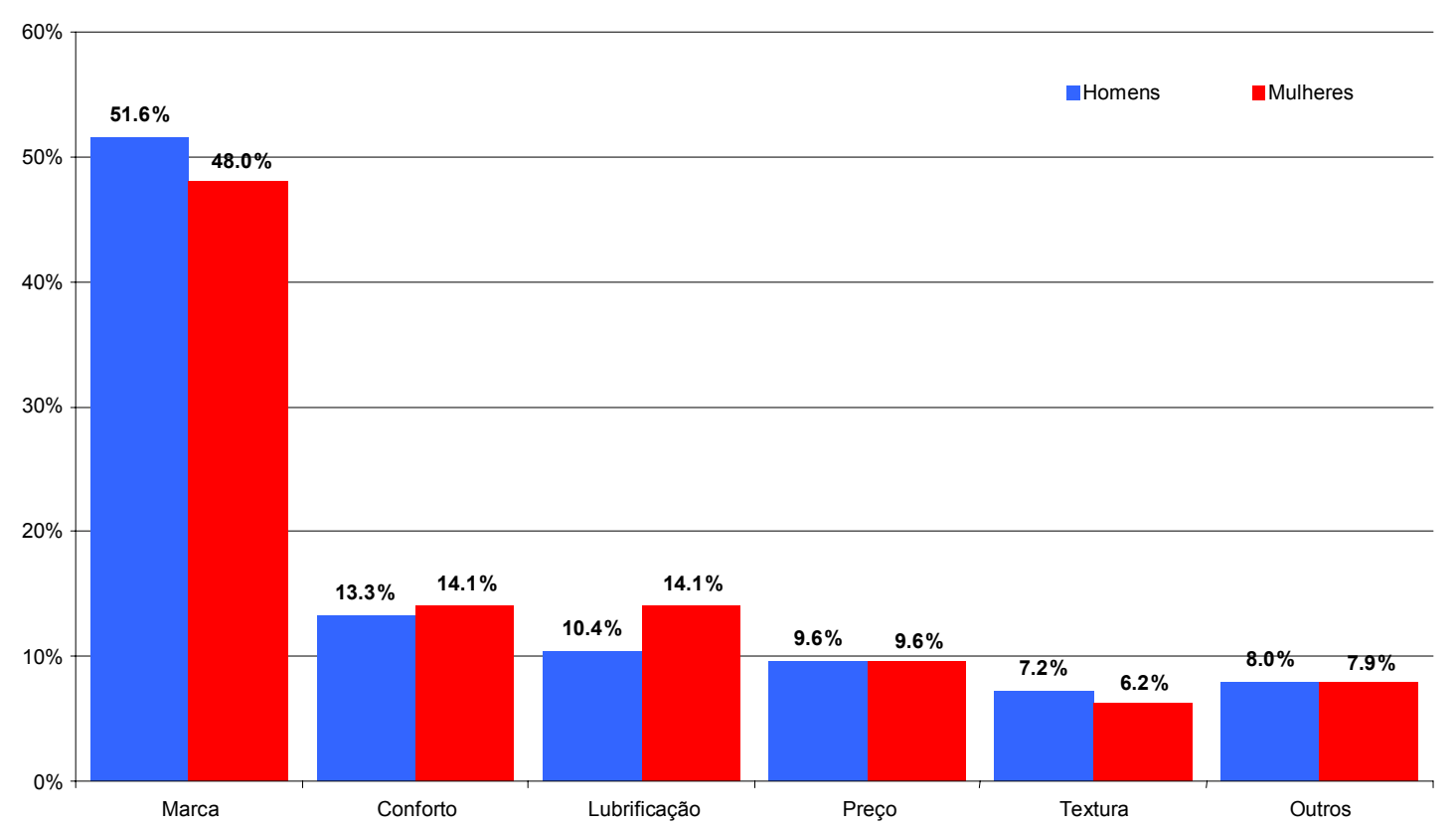

Fonte: MS/SPS/CN-DST/Aids - Acesso a preservativos distribuídos pela rede pública de saúde e padrão de compra de preservativo (MS/IBOPE 2003). Disponível em: <http://www.aids.gov.br/final/biblioteca/ibope 2003/preservativo1.doc>. Acesso em: 18 nov. 2003. 
menos pesa é a embalagem, o tamanho, a cor / sabor e o cheiro, que, para ambos os sexos, têm juntos uma importância de aproximadamente $8 \%$.

Os mais jovens dão mais peso à marca que os mais velhos: dos indivíduos sexualmente ativos entre 14 e 29 anos, 55,9\% citam a marca como o principal atributo na hora de comprar preservativo. A lubrificação é citada por $15,8 \%$ das pessoas sexualmente ativas entre 40 e 49 anos como a mais importante na hora da compra, enquanto a preferência pelo conforto cresce com a idade, chegando a ser apontada por cerca de 19\% das pessoas sexualmente ativas com mais de 50 anos. Nessa mesma faixa de idade, a textura foi citada em primeiro lugar por $14,3 \%$ das pessoas, proporção significativa quando comparada às outras faixas. Para aproximadamente $16 \%$ dos indivíduos entre 40 e 49 anos, o preço é o fator mais importante para a decisão de compra, o dobro da proporção observada em outras faixas de idade. Essa situação pode ser apreciada no gráfico 22 .

Brancos dão maior valor à marca, conforto e lubrificação do que negros. Negros escolheram o preço em primeiro lugar, em uma proporção bem maior que brancos $(12,4 \%$ contra 5,7\%) e também a embalagem e a cor/sabor, apesar de em proporções menos importantes. Mais detalhes são mostrados no gráfico 23.

Gráfico 22 - Distribuição do que as pessoas sexualmente ativas consideram mais importante na hora de comprar preservativos, segundo a cor

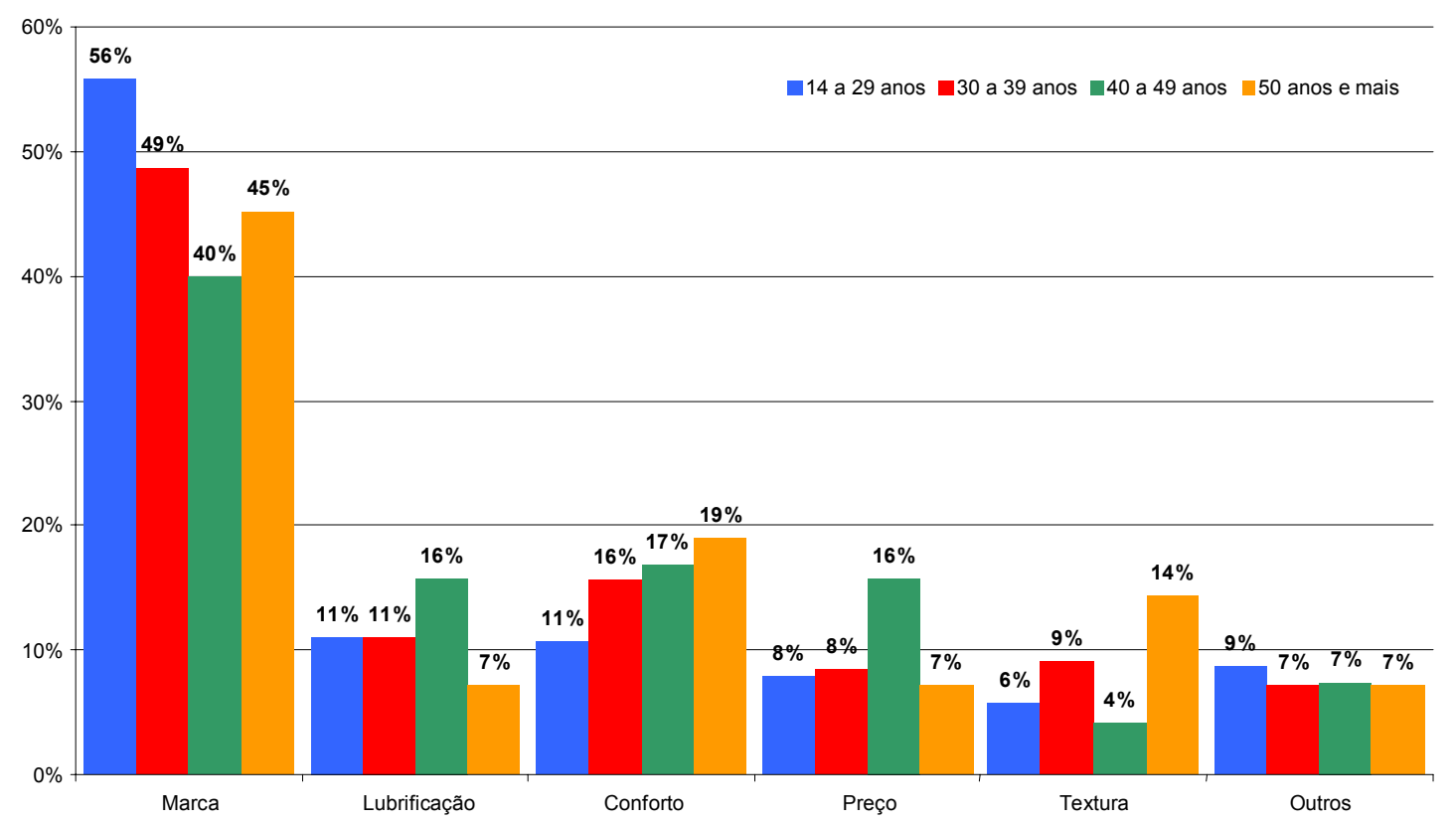

Fonte: MS/SPS/CN-DST/Aids - Acesso a preservativos distribuídos pela rede pública de saúde e padrão de compra de preservativo (MS/IBOPE 2003). Disponível em: <http://www.aids.gov.br/final/biblioteca/ibope 2003/preservativo1.doc>. Acesso em: 18 nov. 2003. 
Gráfico 23 - Distribuição do que as pessoas sexualmente ativas consideram mais importante na hora de comprar preservativos, segundo a cor

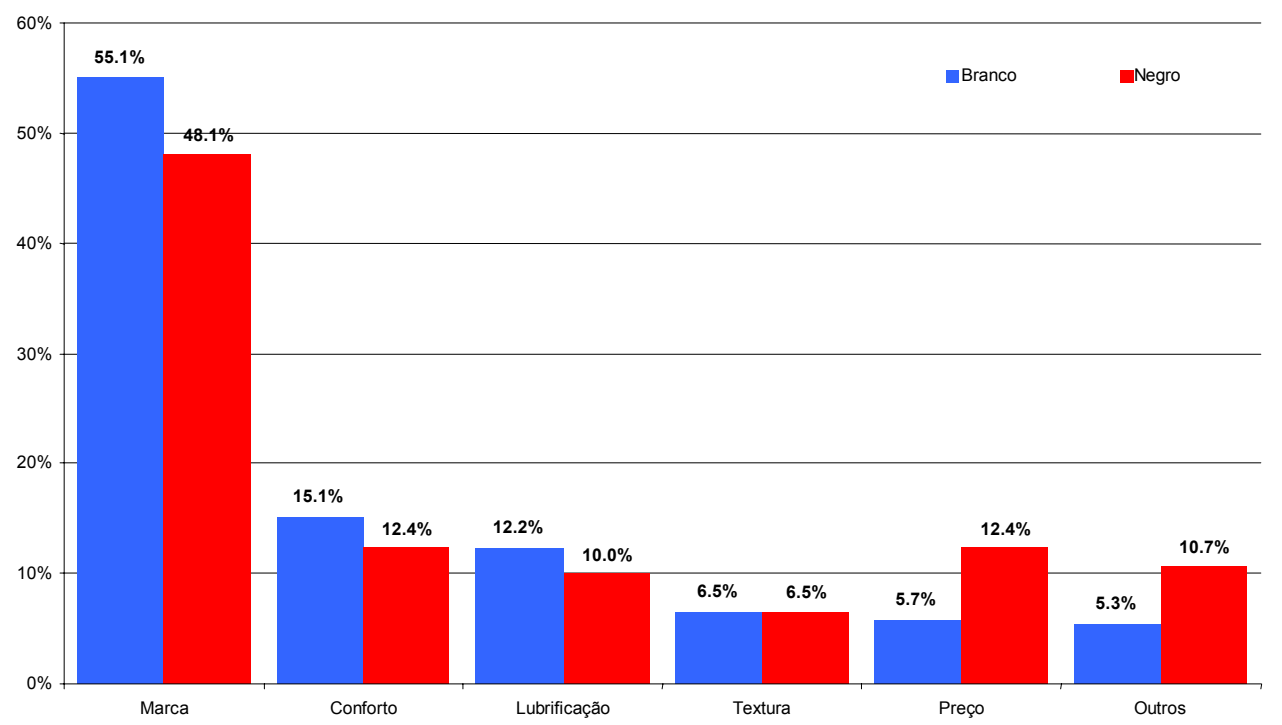

Fonte: MS/SPS/CN-DST/Aids - Acesso a preservativos distribuídos pela rede pública de saúde e padrão de compra de preservativo (MS/IBOPE 2003). Disponível em: <http://www.aids.gov.br/final/biblioteca/ibope 2003/preservativo1.doc>. Acesso em: 18 nov. 2003.

Como pode ser observado no gráfico 24 , entre as classes econômicas, a marca recebeu a preferência de aproximadamente $57 \%$ das pessoas sexualmente ativas da classe $\mathrm{A} / \mathrm{B}$, em um patamar bem superior à proporção da classe $\mathrm{D} / \mathrm{E}$. De maneira oposta, o preço é muito mais importante para os indivíduos da classe $\mathrm{D} / \mathrm{E}$, citando esse atributo cerca de duas vezes mais que as pessoas da classe $\mathrm{C}$ e 1,6 vezes mais que as da classe A/B. Outro atributo com preferência diferenciada entre as classes é a lubrificação, citada pelas pessoas das classes A/B e C cerca de quatro vezes mais do que pelas da classe D/E. Ao contrário, a preferência pela embalagem é maior quanto mais baixa for a classe econômica.

No que diz respeito ao grau de instrução, quanto maior a escolaridade, maior a preferência pela marca e pela lubrificação. A marca foi citada em primeiro lugar por $55 \%$ das pessoas sexualmente ativas com ensino médio ou mais, enquanto a lubrificação contou com a citação de $16,5 \%$ das pessoas dessa mesma classe. Por outro lado, a importância do preço, bem como da embalagem, é menor quanto maior o nível escolar. O conforto é destaque entre as pessoas com grau de escolaridade entre $5^{\mathrm{a}}$ e $8^{\mathrm{a}}$ série, com preferência de 17,6\% delas. Cheiro, tamanho, cor / sabor é mais relevante entre as pessoas até a $4^{\text {a }}$ série. O gráfico 25 permite melhor visualização desse quadro. 
Gráfico 24 - Distribuição do que as pessoas sexualmente ativas consideram mais importante na hora de comprar preservativos, segundo a classe econômica

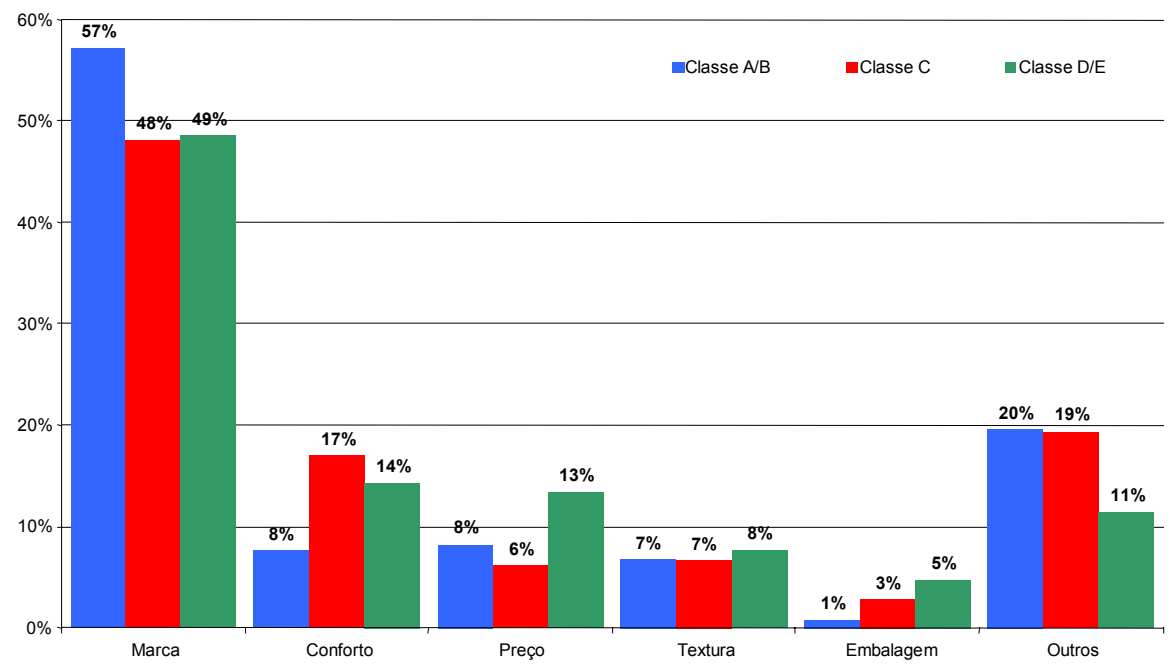

Fonte: MS/SPS/CN-DST/Aids - Acesso a preservativos distribuídos pela rede pública de saúde e padrão de compra de preservativo (MS/IBOPE 2003). Disponível em: <http://www.aids.gov.br/final/biblioteca/ibope 2003/preservativo1.doc>. Acesso em: 18 nov. 2003.

Gráfico 25 - Distribuição do que as pessoas sexualmente ativas consideram mais importante na hora de comprar preservativos, segundo o grau de instrução

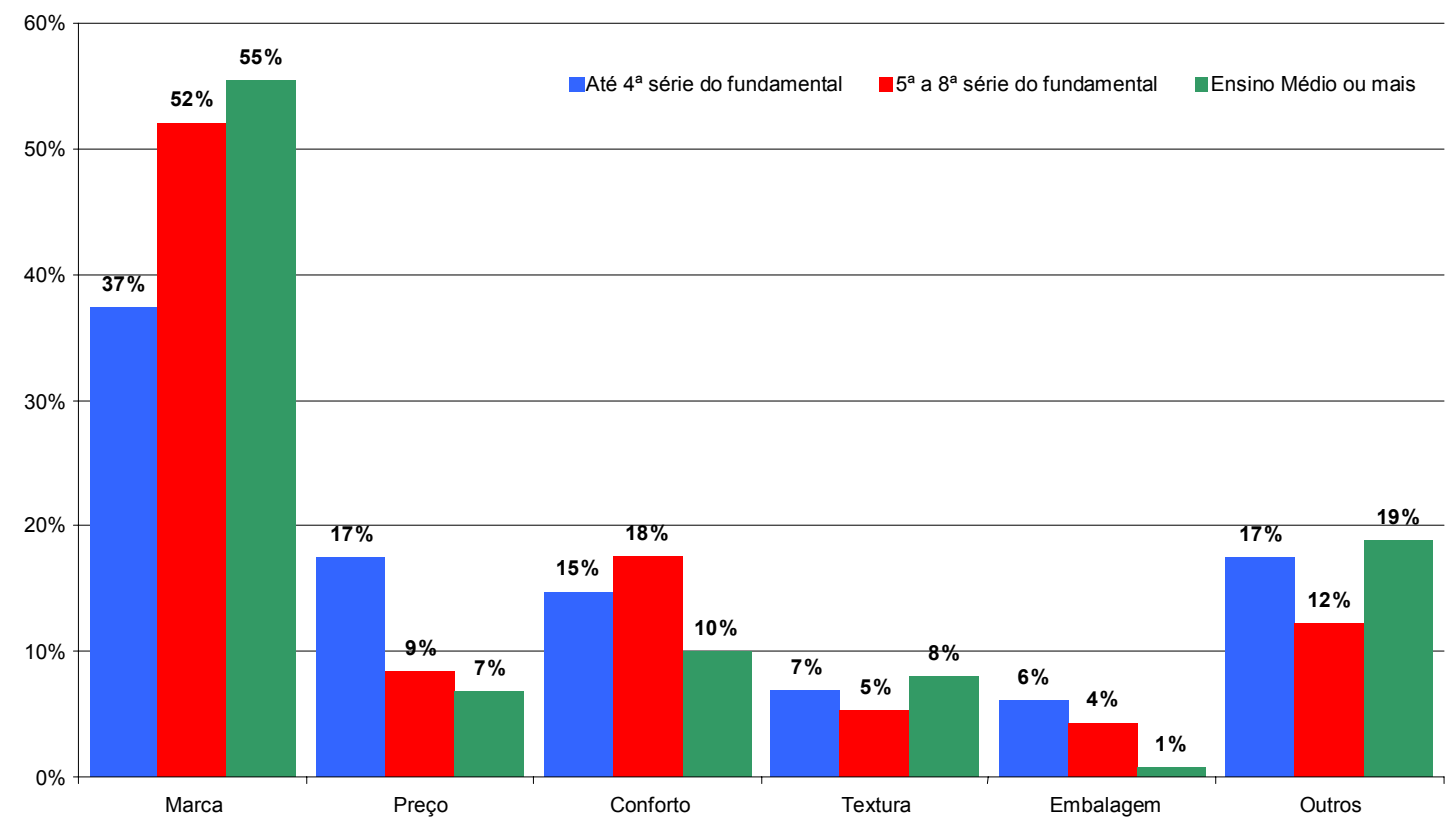

Fonte: MS/SPS/CN-DST/Aids - Acesso a preservativos distribuídos pela rede pública de saúde e padrão de compra de preservativo (MS/IBOPE 2003). Disponível em: <http://www.aids.gov.br/final/biblioteca/ibope 2003/preservativo1.doc>. Acesso em: 18 nov. 2003. 
Segundo o indicador de risco, as pessoas sexualmente ativas que usaram preservativo em todas relações sexuais nos últimos seis meses citaram a marca e a textura como prioritários em proporções significativamente maiores que as do grupo de maior risco, como pode ser confirmado no gráfico 26. Por outro lado, atributos como conforto, lubrificação e preço destacam-se em importância pelo grupo de pessoas que não usaram preservativo em todas relações.

Gráfico 26 - Distribuição do que as pessoas sexualmente ativas consideram mais importante na hora de comprar preservativos, segundo o indicador de risco

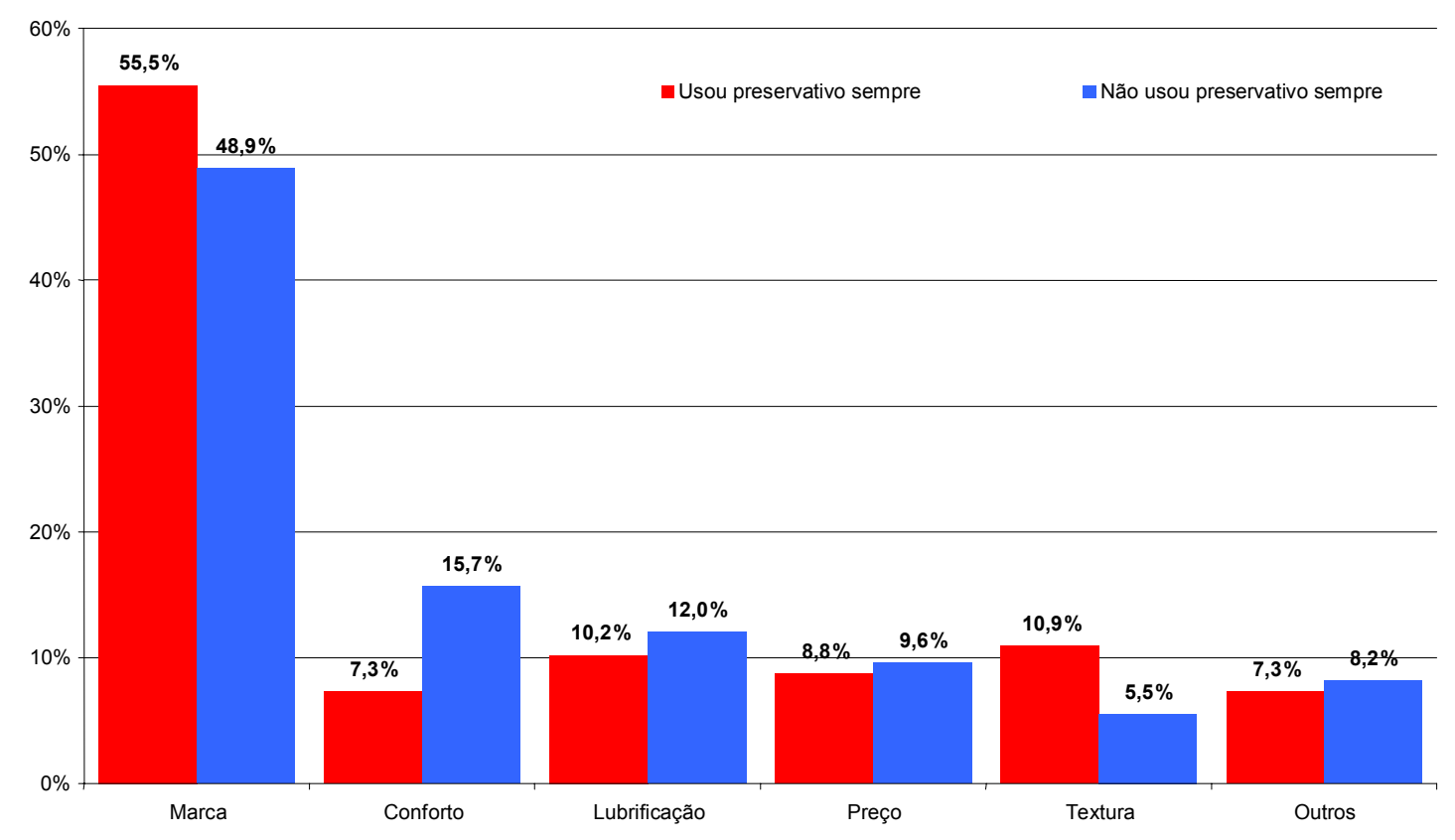

Fonte: MS/SPS/CN-DST/Aids - Acesso a preservativos distribuídos pela rede pública de saúde e padrão de compra de preservativo (MS/IBOPE 2003). Disponível em: <http://www.aids.gov.br/final/biblioteca/ibope 2003/preservativo1.doc>. Acesso em: 18 nov. 2003.

Sob o enfoque do número de relações sexuais por mês, as pessoas com maior freqüência dão mais importância à marca e ao preço e menos importância ao conforto. A lubrificação e o conforto foram mais citados pelas pessoas que têm, em média, 5 a 12 relações mensais, como se pode observar no gráfico 27. 
Gráfico 27 - Distribuição do que as pessoas sexualmente ativas consideram mais importante na hora de comprar preservativos, segundo o número médio de relações sexuais por mês

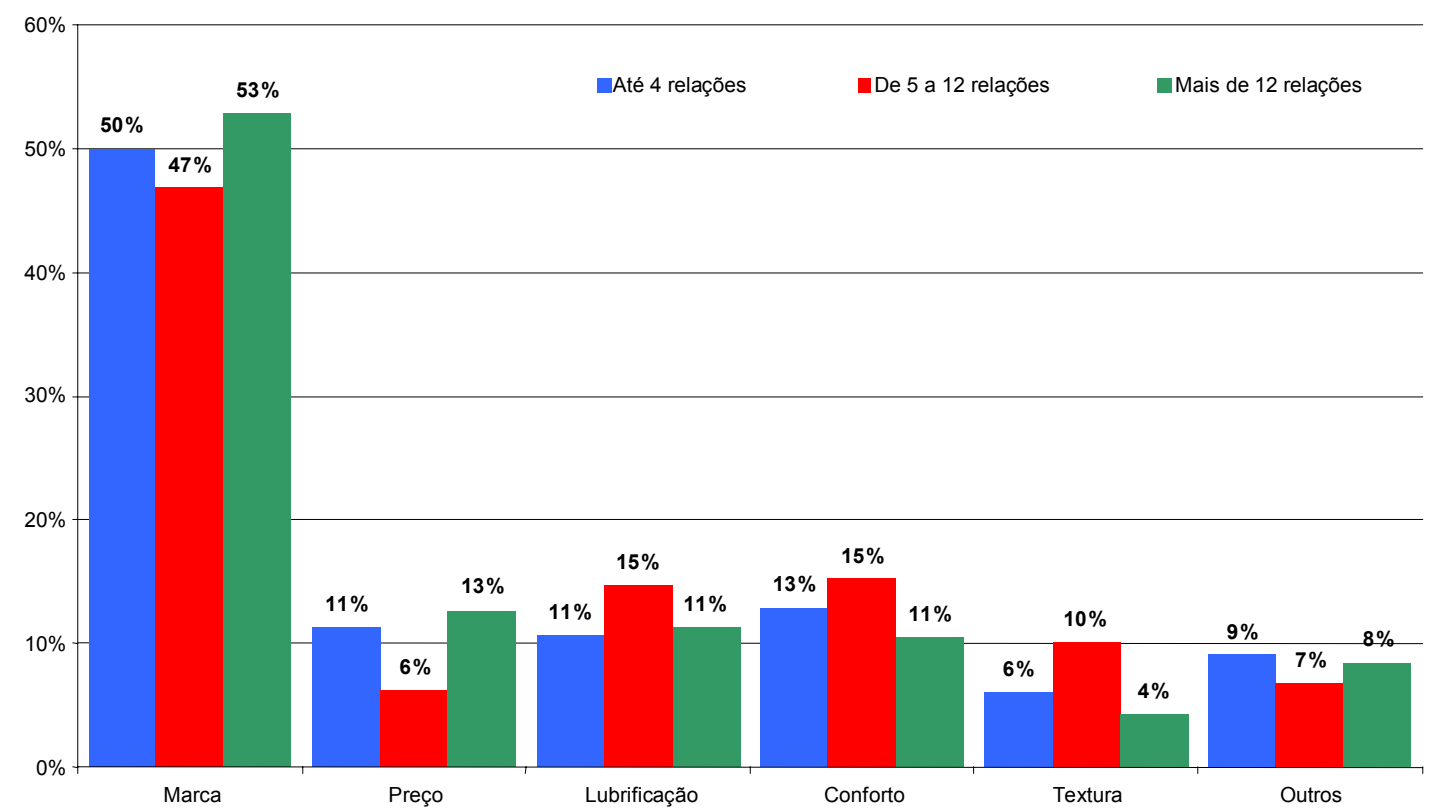

Fonte: MS/SPS/CN-DST/Aids - Acesso a preservativos distribuídos pela rede pública de saúde e padrão de compra de preservativo (MS/IBOPE 2003). Disponível em: <http://www.aids.gov.br/final/biblioteca/ibope 2003/preservativo1.doc>. Acesso em: 18 nov. 2003.

\subsection{PREÇO DO PRESERVATIVO}

O preço é outro atributo cuja relação com a freqüência de uso de preservativo é essencial para embasar este estudo. A pesquisa MS/IBOPE 2003 levantou pontos significativos que também podem ser contemplados segundo diversas variáveis.

De forma geral, cerca de $38 \%$ das pessoas sexualmente ativas declaram que o uso freqüente do preservativo não faz qualquer diferença no orçamento mensal. Faria pouca ou alguma diferença para $31,4 \%$ e muita diferença para $27 \%$. O destaque fica para o contraste entre o Sudeste e o Nordeste, em que, no primeiro, $45,5 \%$ da população sexualmente ativa declaram não fazer qualquer diferença no orçamento o uso freqüente do preservativo enquanto, no segundo, a proporção é de 30,1\%. A maior proporção de pessoas que declararam fazer muita diferença encontra-se no Nordeste e é de 35,7\%. O gráfico 28 ilustra bem essa situação. 
Gráfico 28 - Distribuição das pessoas sexualmente ativas nos últimos 6 meses, de 14 anos e mais, segundo sua opinião sobre se usar o preservativo regularmente faria alguma diferença no orçamento mensal, segundo a região de residência

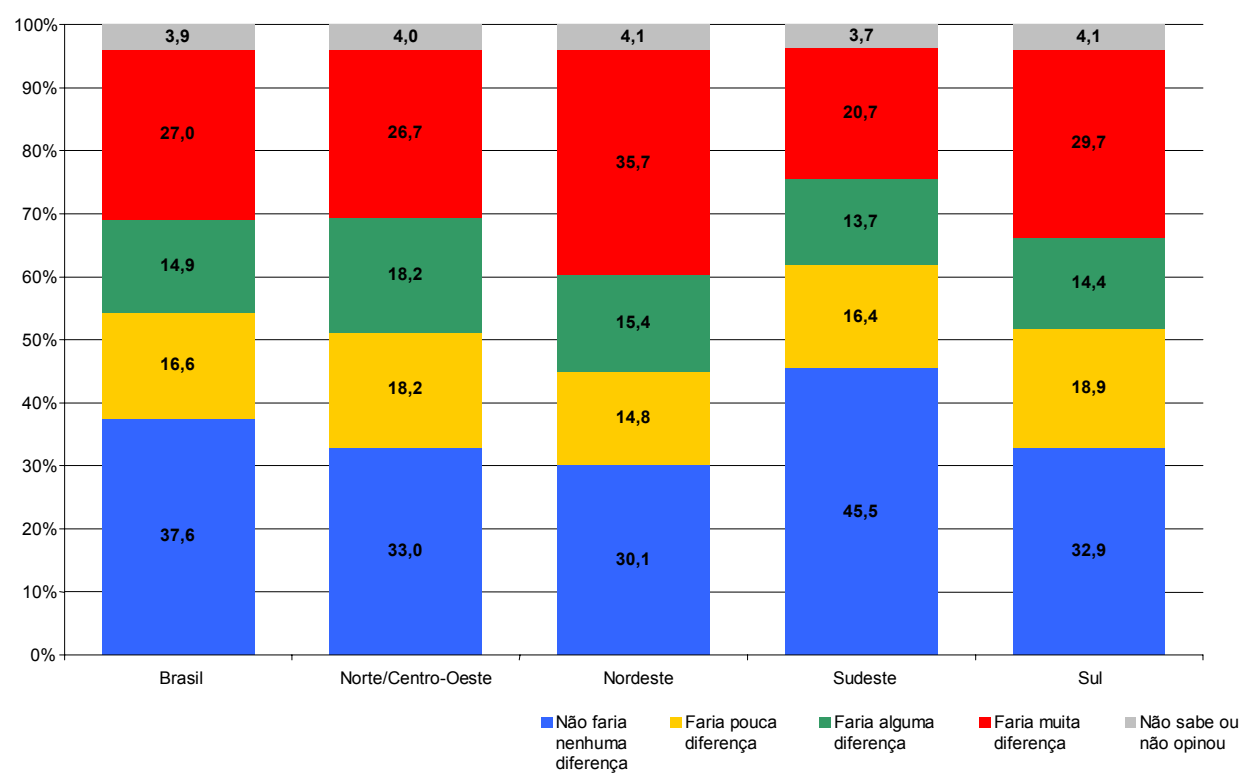

Fonte: MS/SPS/CN-DST/Aids - Acesso a preservativos distribuídos pela rede pública de saúde e padrão de compra de preservativo (MS/IBOPE 2003). Disponível em: <http://www.aids.gov.br/final/biblioteca/ibope 2003/preservativo1.doc>. Acesso em: 18 nov. 2003.

Gráfico 29 - Distribuição das pessoas sexualmente ativas nos últimos 6 meses, de 14 anos e mais, de acordo com sua opinião sobre se usar o preservativo regularmente faria alguma diferença no orçamento mensal, segundo o sexo e a cor/raça

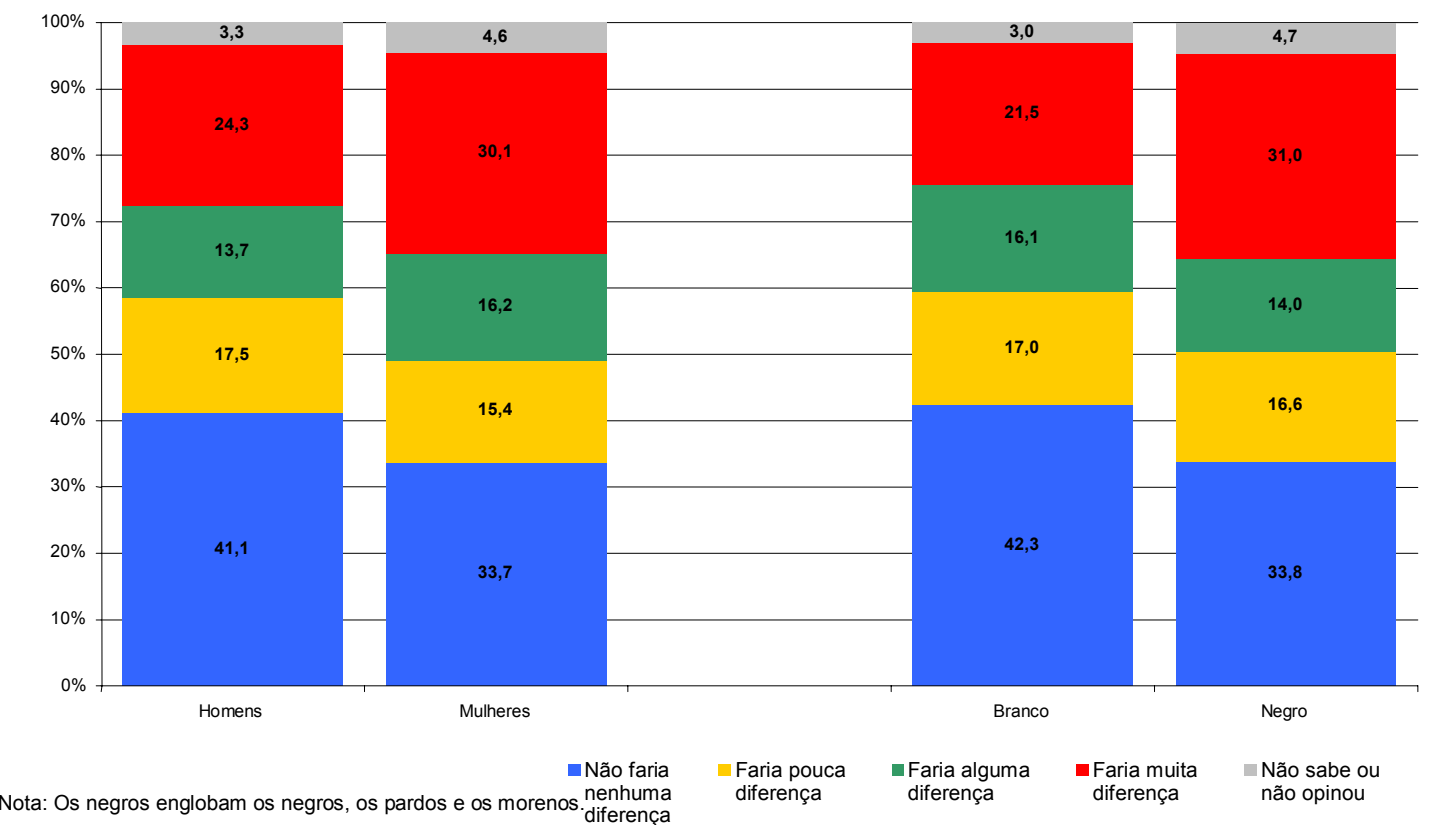

Fonte: MS/SPS/CN-DST/Aids - Acesso a preservativos distribuídos pela rede pública de saúde e padrão de compra de preservativo (MS/IBOPE 2003). Disponível em: <http://www.aids.gov.br/final/biblioteca/ibope 2003/preservativo1.doc>. Acesso em: 18 nov. 2003. 
Segundo o sexo, $41,1 \%$ dos homens declararam não fazer diferença no orçamento o uso regular do preservativo, contra $33,7 \%$ das mulheres. $\mathrm{Na}$ avaliação por cor/raça, as pessoas brancas sentem bem menos no orçamento o uso regular do produto: foram $42,8 \%$ dos brancos contra 33,8\% dos negros. Pelo contrário, 31,5\% dos negros citam que o uso regular do preservativo faz muita diferença. As duas avaliações podem ser vistas no gráfico 29.

Por idade, o grande destaque fica para os jovens de 14 a 19 anos, em cuja faixa houve $50 \%$ de declarações revelando que o uso regular do preservativo não influencia no orçamento. As pessoas de 30 a 39 anos são as que mais declaram sentir o peso do uso regular, com 30,8\% das citações, conforme se observa no gráfico 30 .

Gráfico 30 - Distribuição das pessoas sexualmente ativas nos últimos 6 meses, de 14 anos e mais, de acordo com sua opinião sobre se usar o preservativo regularmente faria alguma diferença no orçamento mensal, segundo a faixa de idade

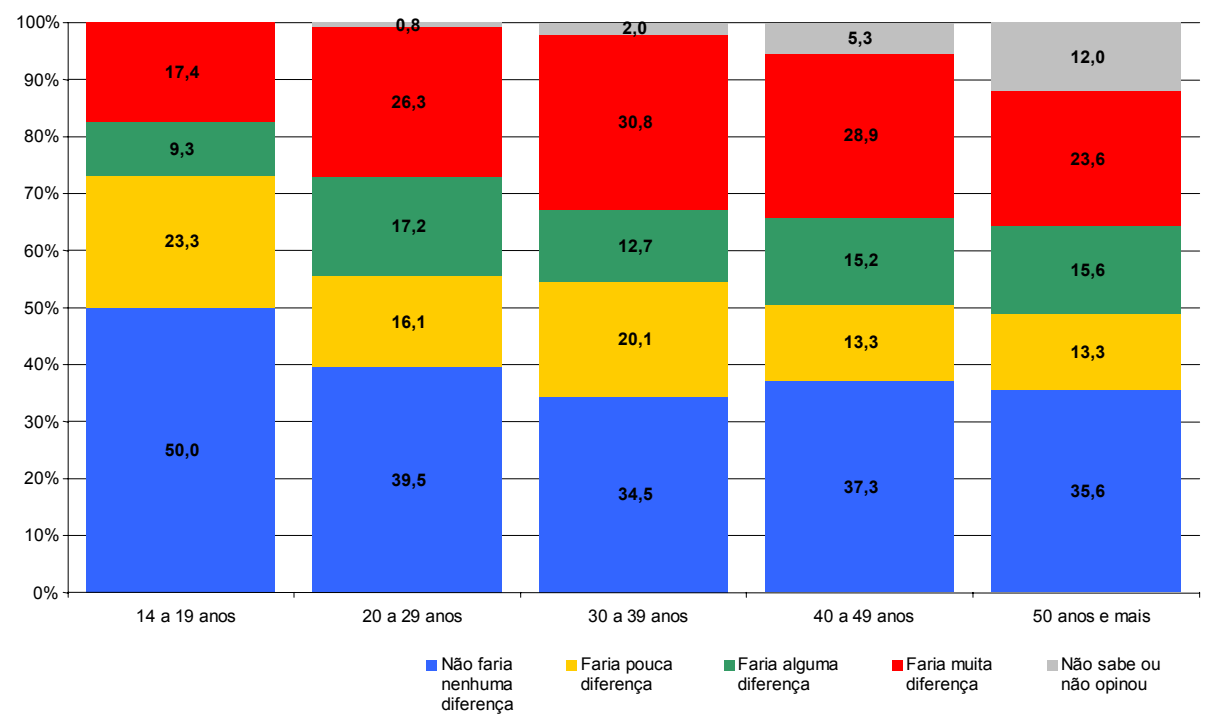

Fonte: MS/SPS/CN-DST/Aids - Acesso a preservativos distribuídos pela rede pública de saúde e padrão de compra de preservativo (MS/IBOPE 2003). Disponível em: <http://www.aids.gov.br/final/biblioteca/ibope 2003/preservativo1.doc>. Acesso em: 18 nov. 2003.

No gráfico 31, nota-se que, na classe $\mathbf{A} / \mathbf{B}$, a proporção de pessoas que não sentem o uso do preservativo pesar no orçamento é de relevantes $53,9 \%, 22 \%$ maior que a observada na classe $C$ e quase o dobro da verificada nas classes D/E. Por outro lado, a proporção dos que sentem muita diferença nas classes $D / E$ é de cerca de $35,6 \%$. 
Outro aspecto analisado é o peso do uso regular do produto no orçamento das pessoas, segundo seu grau de instrução. O que se observa ainda no gráfico 31 é que, quanto maior a escolaridade, menor a proporção dos que declaram a influencia no orçamento. Ao contrário, pessoas com até a $4^{\text {a }}$ série do ensino fundamental declaram que usar o preservativo regularmente faria muita diferença em seu orçamento, em uma proporção de 31,5\% delas.

Quase metade das pessoas que usaram preservativo em todas as relações declararam não sentir a influência do uso regular do produto no orçamento mensal. Essa proporção foi $36,8 \%$ maior que a declarada pelos que não usaram. Quanto ao número médio de relações sexuais mensais, as pessoas com mais de 4 relações médias mensais sentiriam menos o peso do uso regular do produto no orçamento do que aqueles com mais de 12 relações $(42,7 \%$ contra 30,3\%, respectivamente). As duas situações estão expostas no gráfico 32.

Gráfico 31 - Distribuição das pessoas sexualmente ativas nos últimos 6 meses, de 14 anos e mais, de acordo com sua opinião sobre se usar o preservativo regularmente faria alguma diferença no orçamento mensal, segundo a classe econômica e o grau de instrução

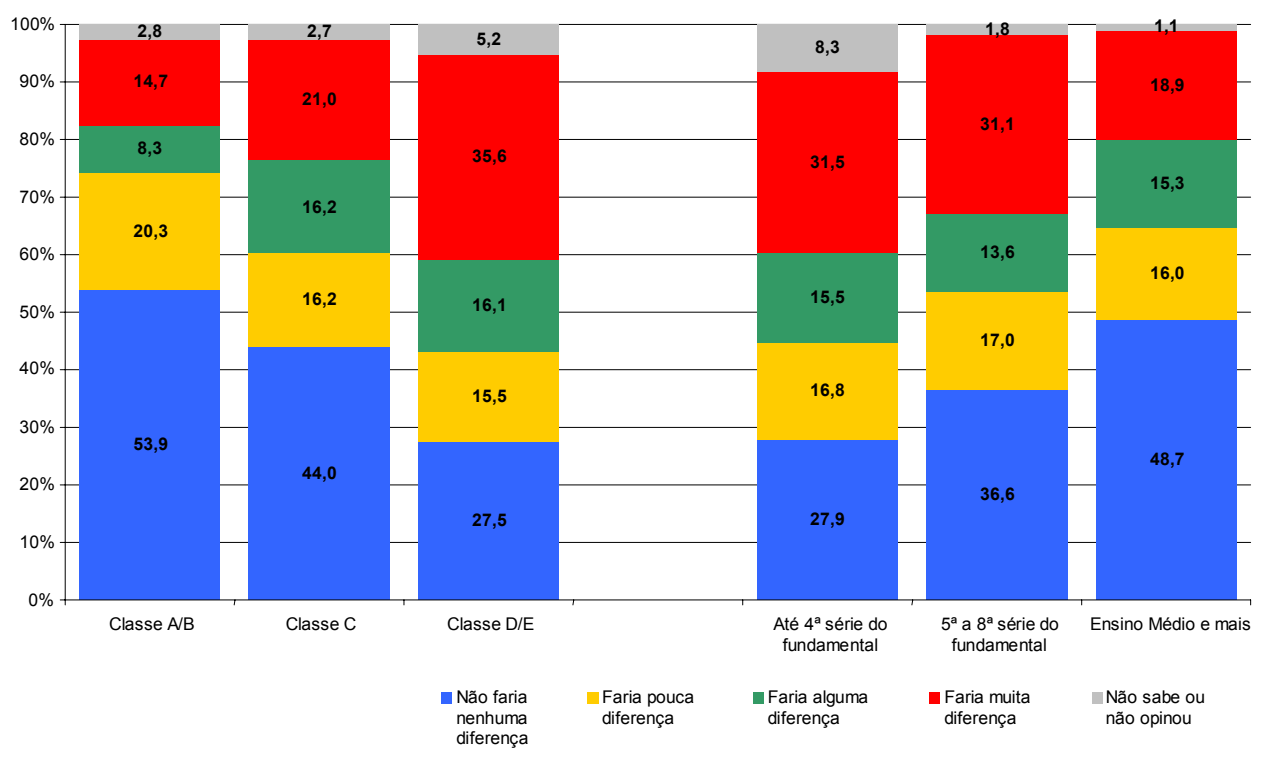

Fonte: MS/SPS/CN-DST/Aids - Acesso a preservativos distribuídos pela rede pública de saúde e padrão de compra de preservativo (MS/IBOPE 2003). Disponível em: <http://www.aids.gov.br/final/biblioteca/ibope 2003/preservativo1.doc>. Acesso em: 18 nov. 2003. 
Gráfico 32 - Distribuição das pessoas sexualmente ativas nos últimos 6 meses, de 14 anos e mais, de acordo com sua opinião sobre se usar o preservativo regularmente faria alguma diferença no orçamento mensal, segundo o indicador de risco e o número de relações por mês

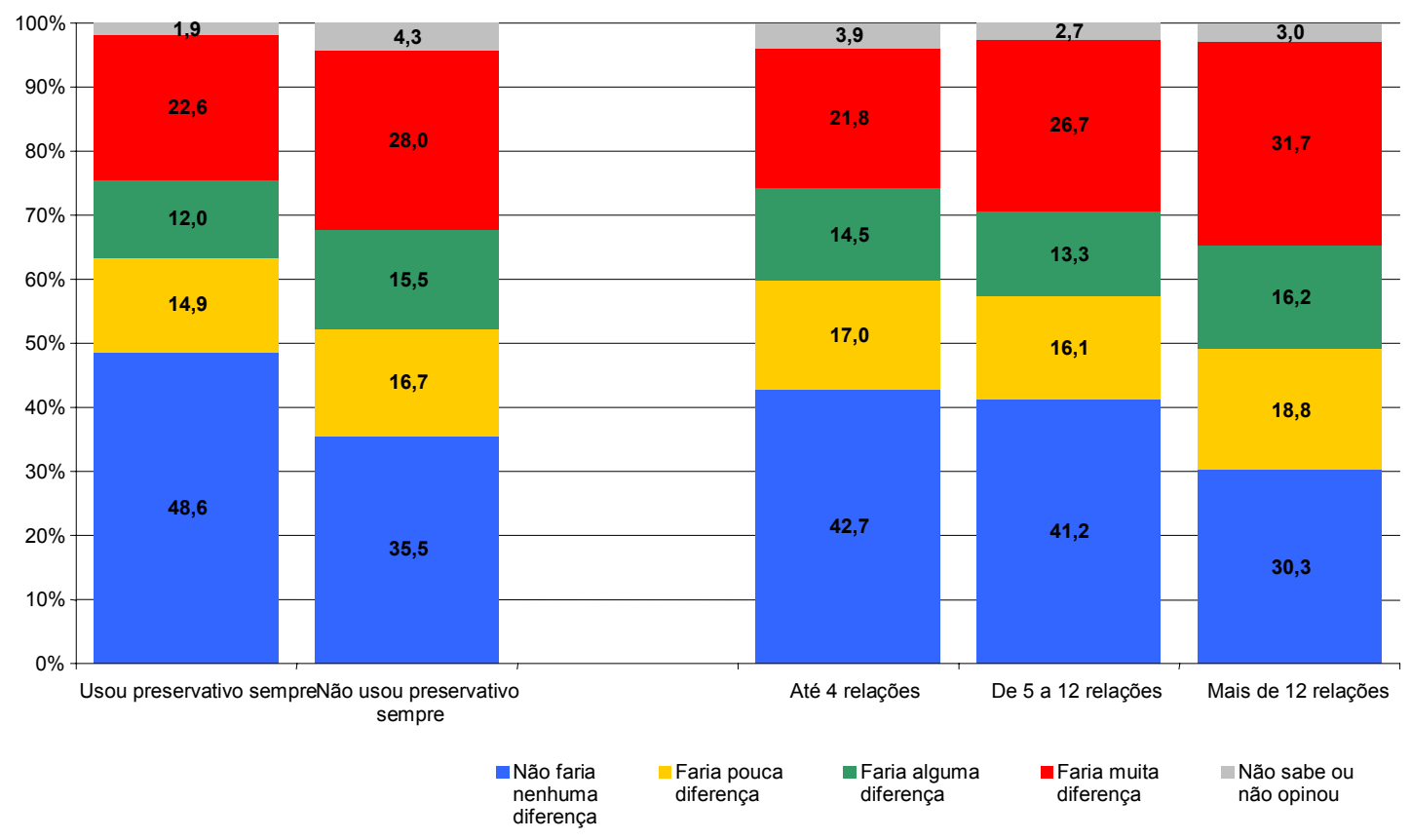

Fonte: MS/SPS/CN-DST/Aids - Acesso a preservativos distribuídos pela rede pública de saúde e padrão de compra de preservativo (MS/IBOPE 2003). Disponível em: <http://www.aids.gov.br/final/biblioteca/ibope 2003/preservativo1.doc>. Acesso em: 18 nov. 2003. 


\section{OUTRA FORMA DE PREVENÇÃO - O PRESERVATIVO FEMININO}

Outra arma que começa a aparecer no mercado e que pode ser importante aliada do preservativo masculino no combate à Aids é o preservativo feminino.

Segundo o Ministério da Saúde (1999), estudo conduzido pelo NEPO / UNICAMP, CEBRAP, UNAIDS e CN-DST / AIDS, a respeito da aceitabilidade do preservativo feminino, observa que uma das maiores dificuldades encontradas pela mulher quanto à imposição de barreiras na relação sexual tem sido a negociação do uso de preservativo pelo parceiro. Em vista disso, resulta que a mulher está buscando novas alternativas de prevenção, com maior autonomia e que a disponibilização daquele produto pode lhe dar maior poder de decisão. Tanto é que, na pesquisa, destaca-se a importância da distribuição gratuita do dispositivo em centros de saúde e do desenvolvimento de trabalhos que ajudem sua desmistificação.

Outro aspecto levantado por um número considerável de mulheres foi a dificuldade com o manuseio do produto, o que mais uma vez reforça a necessidade de uma orientação continuada por parte das autoridades da saúde para a implementação do novo método.

Um resultado que merece ser citado é o de que a aceitabilidade do método foi maior nas mulheres já usuárias de preservativos masculinos e entre as que não precisavam usar contraceptivos. As principais vantagens do produto, descritas pelas mulheres entrevistadas, são as de proteção contra as DSTs (47\%), conforto (39,3\%), autonomia $(29,5 \%)$, resistência $(23,9 \%)$, nenhuma ou pouca interferência na sensibilidade $(20,2 \%)$, aprovação pelo parceiro (20,4\%), higiene $(13,6 \%)$, aumento do prazer (12,9\%), não interrupção da relação sexual $(11,2 \%)$ e inexistência de efeitos colaterais $(10,8 \%)$.

Em outro estudo desenvolvido pelo Programa Nacional de DST / AIDS do Ministério da Saúde (2003), sobre o conhecimento do preservativo feminino, $76 \%$ das pessoas sexualmente ativas (homens e mulheres) conheciam ou já tinham ouvido falar do produto. Entretanto, apenas 3,3\% delas já haviam feito uso dele - o que corresponde a $2,5 \%$ da população sexualmente ativa de 14 anos ou mais.

Importante destacar que quanto maior o poder aquisitivo, maior a proporção de pessoas que já tinham ouvido falar sobre o produto. Entre as pessoas da classe A/B, aproximadamente $88,0 \%$ o conheciam, proporção essa $35 \%$ maior que a observada entre as pessoas da classe $\mathrm{D} / \mathrm{E}(65,3 \%)$. 


\section{PARTE IV}

\section{METODOLOGIA DE PESQUISA DE CAMPO}

\section{O PROBLEMA DE PESQUISA}

A compreensão do comportamento do consumidor de baixa renda vem ganhando enfoque no cenário corporativo do Brasil, principalmente porque as empresas passaram a enxergar esse público com olhos de quem avalia novas oportunidades de crescimento.

Estudo do BCG (2002) faz importante consideração a esse respeito:

Os consumidores das classes A e B, devido ao maior consumo e ao poder de compra, foram tradicionalmente os alvos principais de fabricantes e varejistas. Entretanto, estes consumidores de renda mais elevada, e consumo potencialmente próximo à saturação, são cada vez mais disputados por uma oferta de produtos e serviços altamente competitiva.

Além dessa consideração, vale ressaltar o resultado de pesquisa apontado na seção 10.1, que mostra a redução da proporção de brasileiros sexualmente ativos que usaram preservativo, em todas as relações, o que se configura em uma situação adversa diante do quadro geral de contaminação pelo vírus HIV.

Os achados nas fontes secundárias de dados para a realização deste trabalho sugerem que ainda há espaço para muita contribuição ao estudo do comportamento de compra de preservativos pelas classes de baixa renda no Brasil e, assim, reforça o interesse desta dissertação pelo assunto.

Compreender a importância e a relação entre os diversos atributos de produto que o consumidor de baixa renda leva em conta na compra de preservativos é de grande relevância para se começar a entender como tornar o referido produto mais acessível.

Devido a essas considerações, o problema de pesquisa a ser abordado passa pela seguinte questão:

Quais os principais atributos de produto e seus pesos relativos na tomada de decisão de compra de preservativos pelo consumidor de baixa renda? 


\section{OBJETIVO DA PESQUISA DE CAMPO}

Tendo em vista o problema levantado, o objetivo da pesquisa de campo resume-se em buscar caminhos para respondê-la.

Desta forma, a pesquisa deve contribuir com os objetivos gerais do estudo e permitir um maior aprofundamento na identificação dos atributos do preservativo considerados mais importantes pelo consumidor de baixa renda na hora da compra, determinando o peso relativo entre eles. 


\section{TIPO DE PESQUISA}

Kinnear (1996, p.126) ressalta o papel que a pesquisa deve desempenhar, tanto na formulação do problema como na estimulação do processo criativo envolvido na identificação dos caminhos alternativos de ação. Além disso, destaca a importância do estabelecimento de claros objetivos para a pesquisa e a necessidade de informações detalhadas. O sucesso do projeto formal de pesquisa é altamente dependente da habilidade de como essas questões preliminares são conduzidas.

Uma vez que a fase inicial do processo de pesquisa tenha sido desenvolvida adequadamente, pode-se partir para o desenho do projeto formal e identificar as fontes de dados apropriadas para o estudo. Aaker, Kumar e Day (2001, p.94) classificam as pesquisas em três categorias distintas: exploratórias, descritivas e causais.

Segundo os referidos autores, a pesquisa exploratória é "usada quando se busca um entendimento sobre a natureza geral de um problema, as possíveis hipóteses alternativas e as variáveis relevantes que precisam ser consideradas”. Kinnear (1996, p.127) reforça que a pesquisa exploratória é apropriada para os primeiros estágios do processo de tomada de decisão do caminho a seguir. Esse tipo de pesquisa é usualmente aplicado para se obter uma investigação preliminar da situação com um mínimo de custo e tempo, tendo um desenho caracterizado pela flexibilidade, de forma a detectar situações imprevistas e desvendar idéias previamente não imaginadas. É empregada uma abordagem ampla e versátil, que inclui, dentre outros recursos, as fontes de dados secundárias, observação, entrevistas com especialistas, entrevistas em grupo com pessoas conhecedoras do assunto e estudos de casos.

A pesquisa descritiva, por sua vez, pode ser utilizada quando o propósito é o de descrever características ou perfís de um grupo, conforme Mattar (1999, p.86).

A pesquisa causal é aplicada quando é importante mostrar que uma variável determina o valor de outras variáveis, segundo Aaker, Kumar e Day (2001, p.96).

Considerando que o tema em questão sugere uma investigação preliminar, ao mesmo tempo em que busca descrever as características de um grupo específico da população - a classe popular -, a abordagem adotada pela pesquisa foi do tipo exploratória - descritiva. Dados os objetivos de investigação, o principal método de análise utilizado foi o da Conjoint Analysis, apresentado na seção 17. 


\section{UNIVERSO}

$\mathrm{O}$ universo da pesquisa foi constituído por indivíduos pertencentes às classes $\mathrm{C}, \mathrm{D}$ e E, definidas pelo Critério de Classificação Econômica Brasil, da faixa etária de 18 a 53 anos, sexualmente ativos e usuários freqüentes de preservativo (que o utilizaram pelo menos nos últimos 3 meses). Por conveniência, a coleta de dados foi efetuada com moradores da Grande São Paulo.

Conforme se observou na seção 10.2, informações de executivos da Johnson \& Johnson dão conta de que os homens são os maiores responsáveis pelo volume de compras de preservativo. Para priorizar a compreensão do comportamento da parcela mais representativa dos compradores, este estudo foi focado em indivíduos do sexo masculino. 


\section{AMOSTRAGEM}

Para Mattar (1997, p.260), "amostra é qualquer parte de uma população" e "amostragem é o processo de colher amostras de uma população". A idéia por trás do processo é a de que a coleta de dados em alguns elementos da população pode bastar para fornecer informações relevantes sobre o todo.

O referido autor menciona as vantagens em se amostrar, destacando: a economia de mão-de-obra e dinheiro, dada a redução do número de entrevistas mediante o que seria se a população tivesse que ser integralmente entrevistada; a economia de tempo e rapidez na obtenção dos resultados; a possibilidade de coleta de dados mais precisos, dados os inúmeros erros amostrais que podem surgir em um censo.

Mattar (1997, p.266) ainda chama atenção para os dois tipos possíveis de amostra: probabilístico e não probabilístico. A amostragem probabilística é "aquela em que cada elemento da população tem uma chance conhecida e diferente de zero de ser selecionado para compor a amostra". A amostragem não probabilística é "aquela em que a seleção dos elementos da população para compor a amostra depende, ao menos em parte, do julgamento do pesquisador no campo. Não há nenhuma chance conhecida de que um elemento qualquer da população venha a fazer parte da amostra".

Avaliou-se, para esse estudo, que o tipo de amostra mais adequado é o não probabilístico. Segundo Mattar (1997, p.267), a primeira razão para seu uso é o fato de não haver outra alternativa viável; por exemplo, a população toda não estar disponível para sorteio. A segunda razão é ser a amostragem probabilística superior tecnicamente, mas, na prática, enfraquecer-se por causa de fatores como seleção incorreta de respondentes pelos entrevistadores, omissão de perguntas, recusa à entrevista pelos elementos selecionados ou sua ausência quando procurados. A terceira razão pode ser que o propósito da pesquisa não exija representatividade exata da população. A quarta e última razão refere-se ao nível de exigência de recursos, como tempo, recursos financeiros, materiais e humanos, que uma pesquisa probabilística requer.

Considerando o caráter também exploratório deste estudo, cujas razões foram justificadas na seção 11, foi escolhida uma amostra não probabilística por conveniência, com 102 elementos e perfil já descrito na seção 15, de tal forma a permitir, com os resultados, observações de tendências, mesmo não havendo representatividade estatística. Não foi 
obedecida, para a amostra, a mesma proporção de indivíduos de cada classe observada na população, sendo ela composta de 65 indivíduos da classe C, 29 da D e 8 da E. 
A escolha do método de análise levou em consideração que o problema a ser tratado está centrado na identificação dos atributos mais relevantes de um produto e na determinação de sua importância relativa.

Um procedimento que permite identificar as características mais importantes do produto e consegue classificá-las por meio da comparação entre si é o da Conjoint Analysis.

Trata-se de um método que, segundo Aaker, Kumar e Day (2001, p.614), “oferece uma medida quantitativa da importância relativa de um atributo em comparação com outro".

Para Kotler (2000, p.139), "análise conjunta é uma técnica por meio da qual as preferências dos entrevistados, no que diz respeito a diferentes ofertas, são decompostas para se determinar o grau de utilidade suposto para cada atributo e sua importância”.

O manual de treinamento do SPSS 11.0 (2001) destaca que a conjoint analysis “fornece informação sobre as percepções referentes às comparações entre as diferentes características (atributos) do produto, que ajuda a guiar seu desenvolvimento e posicionamento". O uso dessa técnica dá-se, principalmente, na fase de desenho do produto, ajudando a estabelecer um conjunto de atributos desejáveis e a investigar comparações entre atributos. O mesmo manual ainda aponta que "a meta da conjoint analysis é o entendimento de quais atributos são importantes ao respondente / consumidor e quais níveis de atributos são mais ou menos preferidos".

Artes (1991), designando a conjoint analysis também por análise de preferência, caracteriza-a por "processos que permitam obter e analisar, através da estimação de modelos, experimentos cujas variáveis respostas expressam preferências individuais".

A definição que Hair Jr et al (1995, p.560) apresentam para a técnica diz respeito à compreensão de como os respondentes têm preferências por produtos ou serviços. Eles comentam:

É baseada na simples premissa de que consumidores avaliam o valor de um produto / serviço / idéia (real ou hipotética) por meio da combinação de quantidades separadas de valor oferecidas por cada atributo. Utilidade, que é o conceito básico para medir valor em conjoint analysis, é um julgamento subjetivo da preferência única de cada indivíduo. Ela compreende todas as características do produto ou serviço, ambas 
tangíveis ou intangíveis, e dessa forma, é uma medida da preferência total. $\mathrm{Na}$ conjoint analysis, se assume a utilidade como sendo baseada no valor colocado em cada um dos níveis dos atributos e expressos num relacionamento pela reflexão da maneira na qual a utilidade é formulada por qualquer combinação de atributos. Por exemplo, devemos somar os valores utilitários associados a cada característica de um produto ou serviço para chegarmos à utilidade total. Então, assumiríamos que produtos ou serviços com valores utilitários mais altos são mais preferidos e têm uma maior chance de escolha.

Os autores mencionados anteriormente complementam, afirmando que esse método é o único entre os multivariados em que o pesquisador primeiro constrói um conjunto de produtos ou serviços reais ou hipotéticos pela combinação de níveis selecionados de cada atributo. Tais combinações são então apresentadas para os respondentes, que fazem sua escolha, sem tecer considerações sobre os atributos individuais. "A importância de cada atributo e o valor de cada um pode ser determinada pela classificação geral dada pelo respondente".

A metodologia pressupõe uma seqüência organizada de trabalho. Com o objetivo de manter o processo o mais simples possível, Gustafsson, Ekdahl e Bergman (1999) sugerem que, em uma conjoint analysis, sejam incluídos, pelo menos, os seguintes passos:

\section{Passo 1: Determinação do problema de pesquisa específico e seus objetivos}

O problema deve ser o mais focado possível, de forma a ser resolvido pela identificação de comparações entre um número limitado de atributos e seus níveis. Se muitos atributos forem incluídos, há o perigo de haver respostas inapropriadas à pesquisa. Quanto mais o respondente for familiar ao tema ou produto, maior o número possível de atributos a ser explorado. Os autores ressaltam que o propósito da pesquisa é identificar qual a melhor maneira de compor o produto, de forma a atrair clientes, e determinar o melhor preço de venda.

\section{Passo 2: Determinação de uma população e um procedimento amostral apropriados}

Os procedimentos possíveis podem ser separados em amostragem probabilística e não probabilística. 


\section{Passo 3: Mecanismo de comunicação}

Por mecanismo de comunicação, os autores referem-se ao formato da pesquisa que, em última análise, afeta diretamente o questionário e o tipo de escala de resposta a ser usado. Dentre os formatos mais importantes, há a entrevista pessoal, a entrevista por computador, levantamento por correio e por telefone. Para Gustafsson (1996) e Wittink et al (1994) citados por Gustafsson, Ekdahl e Bergman (1999), a maneira mais comum de se implementar uma conjoint analysis é por meio da entrevista pessoal, já que os dados coletados terão maior qualidade, uma vez que o controle da situação é mais factível. Além disso, a entrevista pessoal permite uma redução do risco de que o entrevistado sinta que não saiba os objetivos da pesquisa e, mais importante, gera taxas mais altas de resposta com dados de maior qualidade, uma vez que o respondente pode ser guiado ao longo do processo. O lado negativo da entrevista pessoal é o custo.

\section{Passo 4: Os conceitos}

Os atributos e seus níveis devem ser escolhidos de forma a serem realistas e relacionados ao problema. É um fator importante a redução do número de atributos e seus níveis, de forma a minimizar os esforços de estimação. Uma questão a se considerar é qual a forma de se gerar diferentes atributos. Os autores comentam que a forma mais freqüente é por meio de uma combinação de um estudo inicial com informações do cliente. Em alguns casos, principalmente com produtos de baixo envolvimento, os atributos interessantes são comumente óbvios pelo contexto e não há muito espaço para alternativas. Citando novamente Gustafsson (1996), os autores ressaltam três regras referentes a quais atributos incluir nos conceitos apresentados aos entrevistados. Dessas, vale destacar duas: escolher atributos importantes para o entrevistado na situação de compra e escolher os que permitam comparações com os produtos concorrentes, isto é, os que cubram as principais competências.

A escolha dos atributos não é tão simples quanto parece, à medida que muitos aspectos devem ser considerados. O primeiro refere-se ao detalhamento dos conceitos, que deve garantir que as informações neles contidas não confundam os respondentes. Outra consideração importante é a exclusividade dos atributos, isto é, a certeza de que um atributo somente represente um único aspecto do produto ou serviço. O significado dos atributos também deve ser óbvio para os respondentes e os nomes e níveis devem ser escolhidos de forma a minimizar a possibilidade de serem confundidos, o que é particularmente importante, 
tendo em vista que não se espera dos entrevistados que gastem muito tempo avaliando os conceitos.

\section{Passo 5: Desenho matricial}

Segundo Artes (1991, p.1), a técnica de conjoint analysis exige que diferentes formulações do produto sejam construídas por meio de combinações dos níveis dos fatores de interesse (conceitos), para posterior avaliação dos respondentes. Há duas abordagens básicas para se montar esses estímulos: por meio de matrizes trade-off ou de um planejamento perfilcompleto (ARTES, 1991, p.15).

No caso do perfil-completo, os níveis de todos os atributos são combinados, originando os conceitos. O número total de possíveis conceitos é o resultado do produto do número de níveis de cada atributo. Conforme Gustafsson, Ekdahl e Bergman (1999), os conceitos são construídos pelo uso de desenhos ortogonais e por ortogonal se entende que o impacto da resposta de um atributo pode ser medida independentemente da variação nos outros atributos.

As características do planejamento de perfil-completo podem ser mais bem entendidas pelas palavras de Green e Srinivasan (1978, p. 108):

O principal argumento que parece favorecer o uso do procedimento de perfil-completo é que ele oferece uma descrição mais realista do estímulo ao definir os níveis de cada fator e possivelmente levar em conta as potenciais correlações do ambiente entre os fatores no estímulo real. Por outro lado, tem a desvantagem de tornar a tarefa difícil para o respondente, que tem que considerar vários fatores ao mesmo tempo. [...] em contextos onde a correlação do ambiente entre os fatores é grande e o número de fatores no cartão de estímulo é pequeno (mas maior que dois), o procedimento de perfil completo é possivelmente melhor em termos de validade preditiva. No entanto, se a correlação ambiental entre os fatores é pequena e o número de fatores no cartão é grande, o procedimento de dois fatores de cada vez será possivelmente melhor.

Segundo o manual de treinamento do SPSS 11.0 (2001, p.2-2), há duas variantes a serem consideradas no estudo de perfil-completo. Havendo um número de atributos e de níveis não muito elevado, é possível se apresentar ao respondente todas alternativas de produto (conceitos). No entanto, com o aumento desse número, a preocupação é com a validade e a confiabilidade da resposta do entrevistado, já que começa a haver a interferência do elemento fadiga. Nesse caso, em vez de colocar todos os conceitos à prova, é possível se 
escolher adequadamente uma fração de todos eles. É o que a literatura designa por desenho fatorial fracionado, detalhado pelo referido manual (2001, p.2-3) como segue:

\begin{abstract}
Desenhos fatoriais fracionados foram desenvolvidos para experimentos em que havia interesse em examinar os efeitos de muitos fatores, mas o número total de células necessárias para apontar todos os efeitos era demasiado. Pela exclusão de certas células (no nosso contexto, combinações de atributos), um pesquisador pode ficar com um desenho incompleto que permita avaliação de todos os efeitos. A vantagem é que muitos fatores podem ser estudados num único experimento; o custo é a impossibilidade de se estudar os efeitos das interações. A idéia básica é que um dado nível de um fator (atributo) aparece na combinação com cada nível de todos outros fatores num número de vezes igual ou numa proporção constante. Assim, todos os níveis dos outros fatores estão equilibrados quando se estima o efeito de um nível de fator.
\end{abstract}

No SPSS, esses desenhos são obtidos por meio do procedimento Orthoplan, que usa um algoritmo para gerar um conjunto mínimo balanceado de conceitos contendo, pelo menos, o número de alternativas requeridas previamente. O procedimento produzirá um arquivo contendo uma variável para cada atributo, uma variável status e uma variável número de cartão. Cada caso representa um cartão a ser apresentado aos respondentes. Adicionalmente, serão criados cartões holdout, que são alternativas de produto avaliadas pelos respondentes, mas não usadas na fase de estimação da conjoint analysis. Segundo o referido manual (2001, p.3-2), “[..].as classificações atribuídas aos cartões holdout pelos respondentes são comparadas às utilidades esperadas dos cartões com base na conjoint analysis, o que fornece medidas de validação".

No caso da matriz "trade-off”, Artes (1991, p. 17) argumenta:

A matriz trade-off (JOHNSON, 1974), também conhecida na literatura como avaliação dois-por-vez, difere em muito do perfil-completo. Agora, os fatores são dispostos dois a dois em tabelas e em cada uma, separadamente, as combinações de seus níveis serão ordenadas de acordo com a preferência do entrevistado [...].

Um dos inconvenientes associados a este método é a possibilidade de haver uma certa perda em termos de realismo, primeiro porque ao se analisar apenas dois fatores por vez, estarão sendo ignoradas algumas possíveis interações envolvendo um número maior de atributos. Outra situação onde ocorre perda de realismo se dá quando existe uma relação natural forte entre dois (ou mais) fatores (correlação ambiental). 


\section{Passo 6: O questionário}

Para Gustafsson, Ekdahl e Bergman (1999), o método de apresentação dos conceitos aos respondentes deve merecer especial atenção. O questionário é a ferramenta a ser utilizada na coleta dos dados e pode ser baseado em texto, figuras ou apresentação verbal, para assegurar que o entrevistado entenda os conceitos à medida que são expostos. A maneira mais comum é a das descrições verbais, considerada mais fácil e barata que as outras alternativas.

\section{Passo 7: Coleta de dados}

Segundo Gustafsson (1996 apud Gustafsson; EKDAHL; BERgMAn, 1999), há 5 tipos de escala usadas na conjoint analysis: ordem de classificação; notas (por exemplo: 1 a 10); notas verbais (por exemplo: de "definitivamente não compraria" a "definitivamente compraria"); primeiro classifica por ordem e depois distribui os conceitos em uma escala; e primeiro dá nota (divide em diferentes classes) e depois classifica por ordem os conceitos com a mesma nota. Há pontos fortes e fracos em cada um dos critérios apresentados. Os autores (1999) ponderam:

Classificar os conceitos em ordem é considerado mais fácil para os respondentes, já que indicar uma ordem de preferência é menos difícil que estabelecer um grau de preferência (GREEN e SRINIVASAN (1978)). A classificação por ordem, no entanto, não é aplicável em questionários por correio, pois freqüentemente é necessária a orientação para ajudar e facilitar o respondente em sua tarefa. Também, analisar uma resposta em ordem de classificação é difícil porque gera grande variação em si. (ANDERSON (1991); GUSTAFSSON (1993)). Essa desvantagem pode ser eliminada pedindo para os respondentes distribuírem os conceitos sobre uma larga escala após terem-nos colocado em ordem de classificação. Escalas de notas, numéricas ou verbais, são úteis para questionários por correio. Notas verbais são preferíveis para produtos de baixo envolvimento, como cereais, suco ou iogurte, já que geralmente resulta em melhores respostas (GUSTAFSSON (1996)). Quando se usam escalas de notas, é necessário assegurar que os respondentes estão cientes de todos os atributos e níveis antes de avaliar os conceitos, já que os conceitos são avaliados uma a um, sem se preocupar com os outros. Uma extensão interessante quando se usa uma escala verbal é pedir aos respondentes que, após dada a nota, coloquem os conceitos em ordem de classificação. Dessa forma, os respondentes podem dividir o número total de conceitos num tamanho mais administrável" (GUSTAFSSON et al., 1999).

Uma das formas mais comuns de se coletar dados em uma conjoint analysis é por meio do uso de cartões, em que cada conceito (produto hipotético, resultado da combinação 
de diversos atributos) é impresso em um cartão individual. O total de cartões corresponde ao produto do número de níveis de atributos. Solicita-se, em seguida, aos respondentes que os organizem em ordem de preferência.

\section{Passo 8: Análise de dados}

Conforme Gustafsson, Ekdahl e Bergman (1991), há diferentes maneiras de se analisarem dados para estimar as preferências do consumidor, mas os dois mais utilizados são o MONANOVA e a regressão dos mínimos quadrados ordinais (OLS). Esta última é usada em mais de 50\% dos casos, mas, do ponto de vista estritamente estatístico, não é viável para analisar dados em ordem de classificação, uma vez que escalas de ordem de classificação não incluem medidas de distância. No entanto, elimina-se essa deficiência pela introdução de intervalos nas respostas classificadas.

\section{Passo 9: Resultados e avaliação}

Para Gustafsson, Ekdahl e Bergman (1991), o conceito vencedor é aquele que representa o consenso da preferência entre todos os respondentes. em uma pesquisa por conjoint analysis pode haver opiniões muito diferentes com relação aos atributos, o que implica possível segmentação de consumidores. No conceito vencedor, somente um dos possíveis segmentos poderia ser satisfeito totalmente, o que força os elementos do outro segmento a fazerem concessão das suas preferências originais.

\section{Passo 10: Conclusões da pesquisa}

O passo final refere-se à apresentação dos resultados do estudo.

Os passos 1 e 2 foram mostrados nas seções 12 e 13 respectivamente. Os passos seguintes estão apresentados nas próximas seções. 


\section{MECANISMO DE COMUNICAÇÃO}

Tendo em vista o método escolhido e o tipo de pesquisa apropriado para o caso, a forma de comunicação mais adequada com o respondente foi a da entrevista pessoal, visando à maior qualidade dos dados, pelas razões já comentadas.

Uma primeira questão que poderia ter se configurado em obstáculo para a realização da pesquisa foi a localização de indivíduos das classes econômicas C, D e E. No entanto, os entrevistadores procuraram os respondentes em locais com maior probabilidade de encontrálos em São Paulo, como em postos de saúde da periferia da cidade e em estações de trens de subúrbio, onde a população com esse perfil costuma circular. Mas também os achou em locais mais centrais, onde se encontram fixos em seus postos de trabalho, como condomínios, fábricas e até mesmo ruas públicas.

A realização da entrevista exigiu habilidade do entrevistador, uma vez que o instrumento de coleta, como será visto na seção 17 , não se constituiu apenas em uma folha com questionário, mas também em cartões que precisavam ser ordenados pelo respondente além de material de apoio, como desenhos explicativos dos atributos do produto. Como se pode perceber, o entrevistador sempre precisou contar com uma superfície plana para que o entrevistado dispusesse os cartões em ordem. 
Para a escolha dos atributos, partiu-se de um estudo inicial, a pesquisa MS/IBOPE 2003, cujos resultados estão mostrados no gráfico 19 da seção 10.4. Os quatro atributos mais relevantes apresentados foram: marca, conforto, lubrificação e preço. Em um grupo menos importante, estão cheiro / tamanho e cor / sabor.

Parece, portanto, óbvio que os quatro atributos tenham sido os escolhidos para a aplicação da conjoint analysis. No entanto, como a grande maioria dos tipos de preservativos é lubrificada, esse atributo não foi considerado na análise comparativa dos fatores. Assim, procedeu-se o seu descarte e sua substituição por outro de menor preferência na pesquisa mencionada, mas com algum nível de interesse para este estudo, uma vez que novas características têm sido incorporadas no produto mais recentemente. Com essa diretriz, a espessura foi escolhida como o quarto atributo e, oportunamente, uma quinta característica foi adicionada: a textura.

Cada um desses atributos foi associado a alguns níveis, conforme pode ser observado no quadro 7.

Quadro 7 - Os atributos e seus níveis, usados na pesquisa

\begin{tabular}{|c|c|c|c|c|}
\hline MARCA & CONFORTO & PREÇO & ESPESSURA & TEXTURA \\
\hline Jontex & $\begin{array}{c}\text { Com formato } \\
\text { anatômico }\end{array}$ & $\mathrm{R} \$ 1,05$ & Fina & Liso \\
Olla & $\mathrm{R} \$ 2,10$ & & \\
$\begin{array}{c}\text { Outra } \\
\text { marca }\end{array}$ & $\begin{array}{c}\text { Sem formato } \\
\text { anatômico }\end{array}$ & $\mathrm{R} \$ 3,20$ & Grossa & Não Liso \\
\hline
\end{tabular}

Pelas vantagens apresentadas no Passo 5 da sessão 17, a abordagem matricial adotada foi a do planejamento perfil-completo. Com desenho fatorial completo, resultaria em um total de 72 conceitos $(3 \times 2 \times 3 \times 2 \times 2)$, o que representaria certa dificuldade e poderia confundir o respondente. Assim, por meio dos procedimentos Orthoplan do SPSS 11.0, obteve-se o desenho fatorial fracionado, cujos resultados podem ser observados no quadro 8. 
Quadro 8 - Desenho fatorial fracionado obtido do SPSS, mostrando os conceitos resultantes

\begin{tabular}{|c|c|c|c|c|c|}
\hline CARTÃO & MARCA & FORMATO & \begin{tabular}{|c|} 
PREÇO (R\$) \\
embalagem \\
com 3 unidades
\end{tabular} & ESPESSURA & TEXTURA \\
\hline 1 & Olla & Anatômico & 3,20 & Grossa & Lisa \\
\hline 2 & Olla & Não Anatômico & 2,10 & Fina & Não Lisa \\
\hline 3 & Jontex & Não Anatômico & 1,80 & Grossa & Não Lisa \\
\hline 4 & Jontex & Anatômico & 2,10 & Grossa & Lisa \\
\hline 5 & Jontex & Não Anatômico & 3,20 & Fina & Lisa \\
\hline 6 & Olla & Anatômico & 1,05 & Fina & Lisa \\
\hline 7 & Jontex & Anatômico & 2,10 & Grossa & Não Lisa \\
\hline 8 & Jontex & Anatômico & 1,05 & Fina & Não Lisa \\
\hline 9 & Olla & Não Anatômico & 1,05 & Grossa & Não Lisa \\
\hline 10 & Jontex & Anatômico & 1,05 & Fina & Lisa \\
\hline 11 & Outras marcas & Anatômico & 3,20 & Grossa & Não Lisa \\
\hline 12 & Jontex & Não anatômico & 1,05 & Grossa & Lisa \\
\hline 13 & Outras marcas & Anatômico & 1,05 & Fina & Não Lisa \\
\hline 14 & Outras marcas & Não Anatômico & 2,10 & Fina & Lisa \\
\hline 15 & Jontex & Não Anatômico & 3,20 & Fina & Não Lisa \\
\hline 16 & Outras marcas & Não Anatômico & 1,05 & Grossa & Lisa \\
\hline 17 & Olla & Não Anatômico & 3,20 & Fina & Não Lisa \\
\hline 18 & Olla & Anatômico & 3,20 & Fina & Não Lisa \\
\hline 19 & Outras marcas & Não Anatômico & 1,05 & Fina & Não Lisa \\
\hline 20 & Olla & Não Anatômico & 1,05 & Grossa & Lisa \\
\hline
\end{tabular}

Os conceitos sombreados na tabela são holdouts e, como comentado no passo 5 da na sessão 17 , possibilitarão criar medidas de validação. 


\section{QUESTIONÁRIO / COLETA DE DADOS}

A coleta de dados foi feita por meio da utilização de cartões, cada qual mostrando os conceitos apresentados no quadro 8. Foram, portanto, 20 conceitos, apresentados aos respondentes, que os classificaram por ordem de preferência.

Antes de apresentar os conceitos, no entanto, o entrevistado respondeu um questionário que permitiu sua qualificação, com perguntas para informação dos dados cadastrais (idade, ocupação e nível escolar), e os filtros, como o da classificação socioeconômica (conforme Critério de Classificação Econômica Brasil), o do método contraceptivo mais usado e o da freqüência de compra de preservativos. Só foram considerados elegíveis os respondentes das classes C, D ou E, cujo método contraceptivo mais freqüentemente utilizado fosse o dos preservativos e com freqüência de compra mínima do produto de 3 meses. Questões complementares como a da faixa de renda e das unidades adquiridas em cada compra foram incluídas. O modelo do questionário pode ser visto no Apêndice A.

Por serem de uma classe menos elevada e dado o histórico de uso do produto por esse segmento da população, na hora da classificação dos conceitos, os entrevistados receberam explicações cuidadosas sobre a dinâmica do processo e os atributos investigados do produto. Nas situações em que foi necessário, o entrevistador contou com o uso de desenhos explicativos dos atributos e seus níveis, como para o caso da textura (liso e não liso), espessura (fina e grossa) e conforto (formato anatômico ou não anatômico). Com essa filosofia, foi usada uma linguagem mais coloquial, tanto no questionário quanto na entrevista, inclusive designando o preservativo por "camisinha", termo bastante popular.

O uso de exemplares dos produtos com diversas características foi dispensado por causa dos resultados do pré-teste, que apontaram os desenhos explicativos dos atributos como de maior eficácia (ilustração nos Apêndice B). 


\section{PARTE V}

\section{APRESENTAÇÃO E ANÁLISE DOS RESULTADOS}

\section{PROCESSAMENTO DA CONJOINT ANALYSIS}

Quando se usa a conjoint analysis como método de pesquisa, como é o caso deste estudo, o que se busca é a identificação dos atributos considerados mais importantes, bem como o peso relativo e a utilidade dos níveis de cada um.

Segundo o manual de treinamento do SPSS (2001, p.4-1), no processamento da conjoint por meio do referido software, é feita uma regressão que relaciona os atributos de produto à classificação dos conceitos. Como resultado, são calculados coeficientes de utilidade, que associam os níveis de atributos às mudanças naquela classificação, e são apresentadas estimativas de precisão dos resultados (erros-padrão). A importância geral de cada atributo, bem como os índices que mensuram essa importância são apresentados textual e graficamente. Para se usar o software mencionado, é necessário desenvolver um programa com sintaxe própria, que permita o relacionamento de dois arquivos diferentes: o das descrições dos cartões (Plan file) e o das classificações dos conceitos, obtidas dos respondentes (Data file).

Uma vez concluída a etapa de coleta de dados, que resultou em 102 entrevistas válidas, partiu-se para a construção do Data file, o arquivo contendo as classificações dos 20 conceitos de produtos geradas pelos entrevistados, por meio do modo SPSS Data Editor. Apesar de a pesquisa não ter estratificado os entrevistados por classes econômicas, segundo proporções estatisticamente representativas, conforme já comentado, houve interesse em se comparar respostas dos três grupos distintos (classes C, D e E), com a finalidade de observar tendências. Para se conseguir isso, o processamento da conjoint foi planejado para dar respostas em nível de grupo, isto é, os dados dos indivíduos pertencentes a uma determinada classe econômica foram agrupados e os resultados foram gerados nesse nível. Conforme pode ser observado no Apêndice C, a estrutura do Data file guarda um primeiro campo de nome ngroup para tais agrupamentos. Além de conter campo para identificação do número do questionário e campo para cada seqüência escolhida pelo respondente, esse arquivo também traz, em cada registro, as seguintes informações: idade do 
entrevistado, escolaridade do chefe da família, escolaridade do entrevistado, faixa de renda familiar, conhecimento de cada método contraceptivo (camisinha, DIU, anticoncepcionais, espermicida, tabelinha, coito interrompido, implante subcutâneo ou nenhum), freqüência de compra do produto e número médio de unidades levadas a cada compra.

De posse do arquivo do Plan File e do Data file, partiu-se para a estruturação do programa (sintaxe no Apêndice D) que os associa por meio do modo SPSS Syntax Editor. Esse programa gerou quatro grupos de saídas numéricas, uma para cada classe, conforme comentado anteriormente, e uma para o sumário (valores médios). Além deles, um conjunto de saídas gráficas mostra a importância ou utilidade dos níveis de atributo apresentada nas saídas numéricas de forma mais clara. A análise dos resultados está demonstrada em seguida.

\section{APRESENTAÇÃO DOS RESULTADOS E COMENTÁRIOS}

Para o processamento dos dados e análise dos resultados, foi utilizado o programa SPSS 12.0. As saídas do programa estão apresentadas nas Figuras 11, 12, 13 e 14. Para interpretar os resultados, o manual do SPSS (2001, p. 4-9) elucida:

- O termo Subject Name refere-se ao grupo cujos resultados são apresentados; nesse caso, as classes individuais e o sumário (valores médios).

- A coluna Importance expressa em porcentagem a importância de cada atributo, descrito na coluna Factor, em função da ordem de preferência escolhida pelos respondentes. A soma totaliza $100 \%$. Além dos valores numéricos, a coluna inclui uma barra que representa os percentuais.

- A coluna Utility mostra as estimativas de utilidade dos níveis de atributo, isto é, como cada nível está associado à preferência do grupo em análise. Valores positivos indicam que o nível de atributo é preferido pelo grupo, enquanto o contrário ocorre para valores negativos.

- De forma a avaliar o nível de associação entre as utilidades previstas pelo modelo de conjoint e o ranking dos conceitos, duas medidas são apresentadas: uma é o coeficiente de correlação $\mathrm{R}$ de Pearson e a outra é o coeficiente de Kendall, que atingem um valor máximo de 1. Quanto mais alto o indicador, mais forte a relação. 
Figura 11 - Saída numérica do programa por classe (classe C)

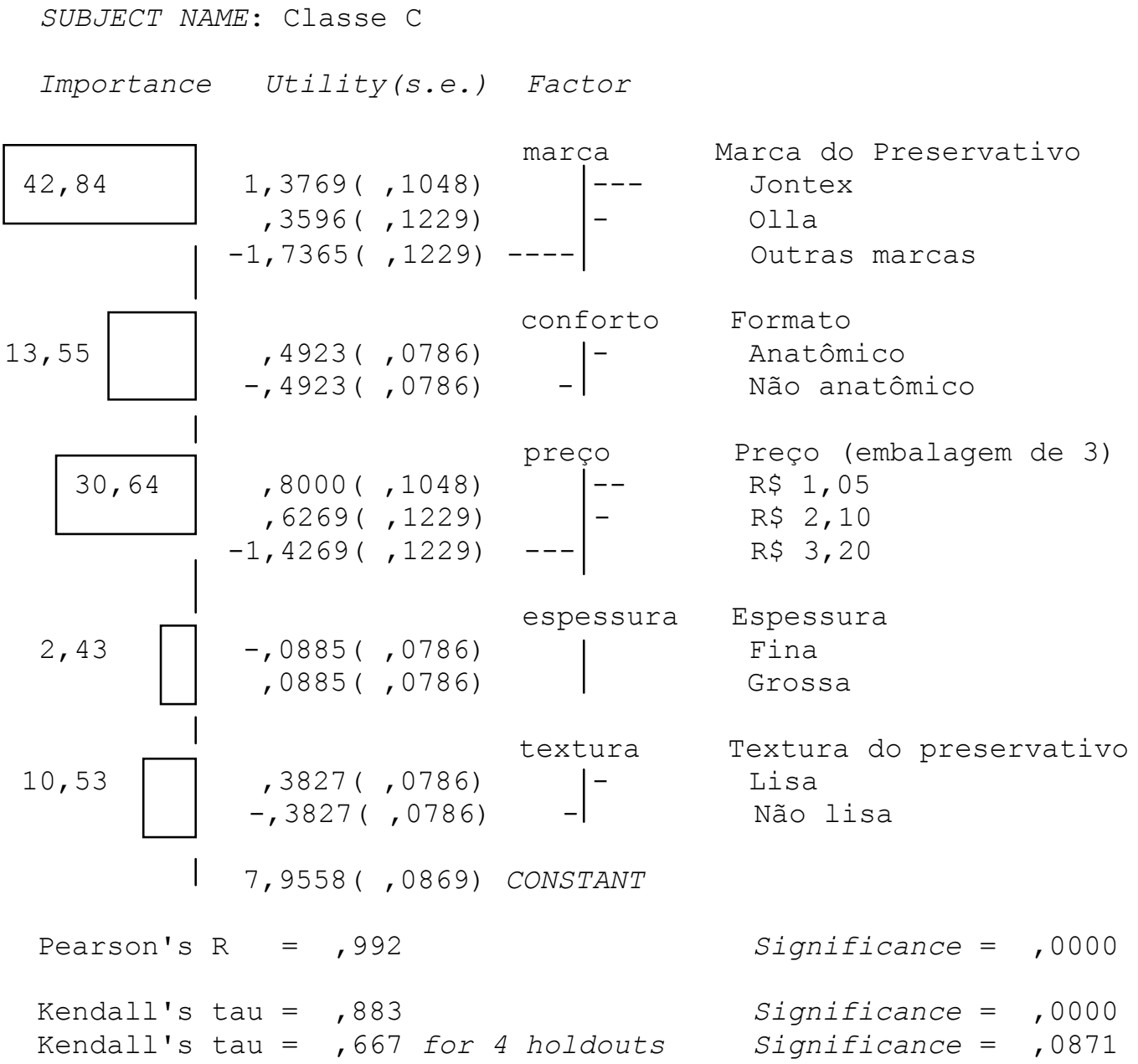


Figura 12 - Saída numérica do programa por classe (classe D)

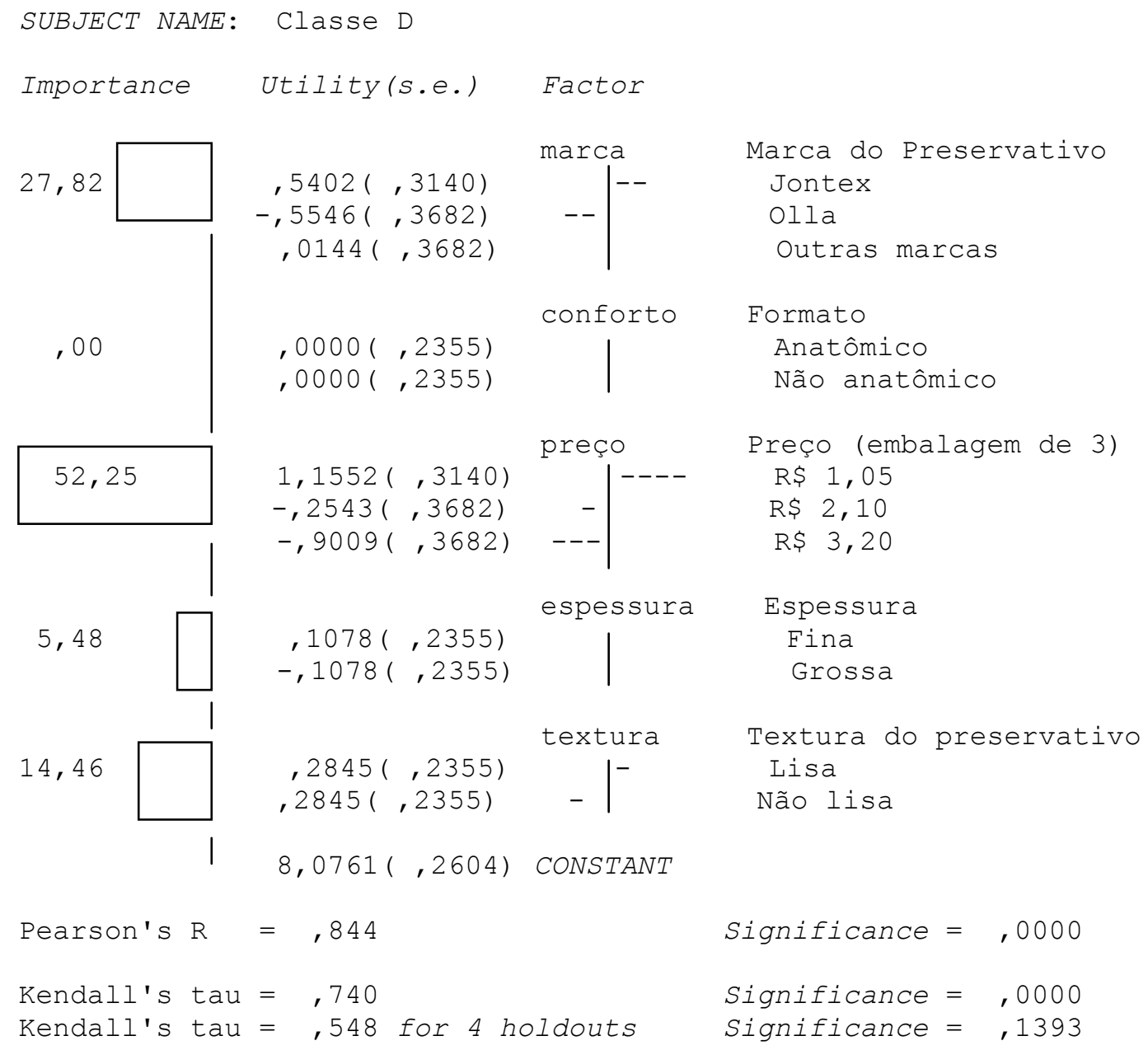




\section{Figura 13 - Saída numérica do programa por classe (classe E)}

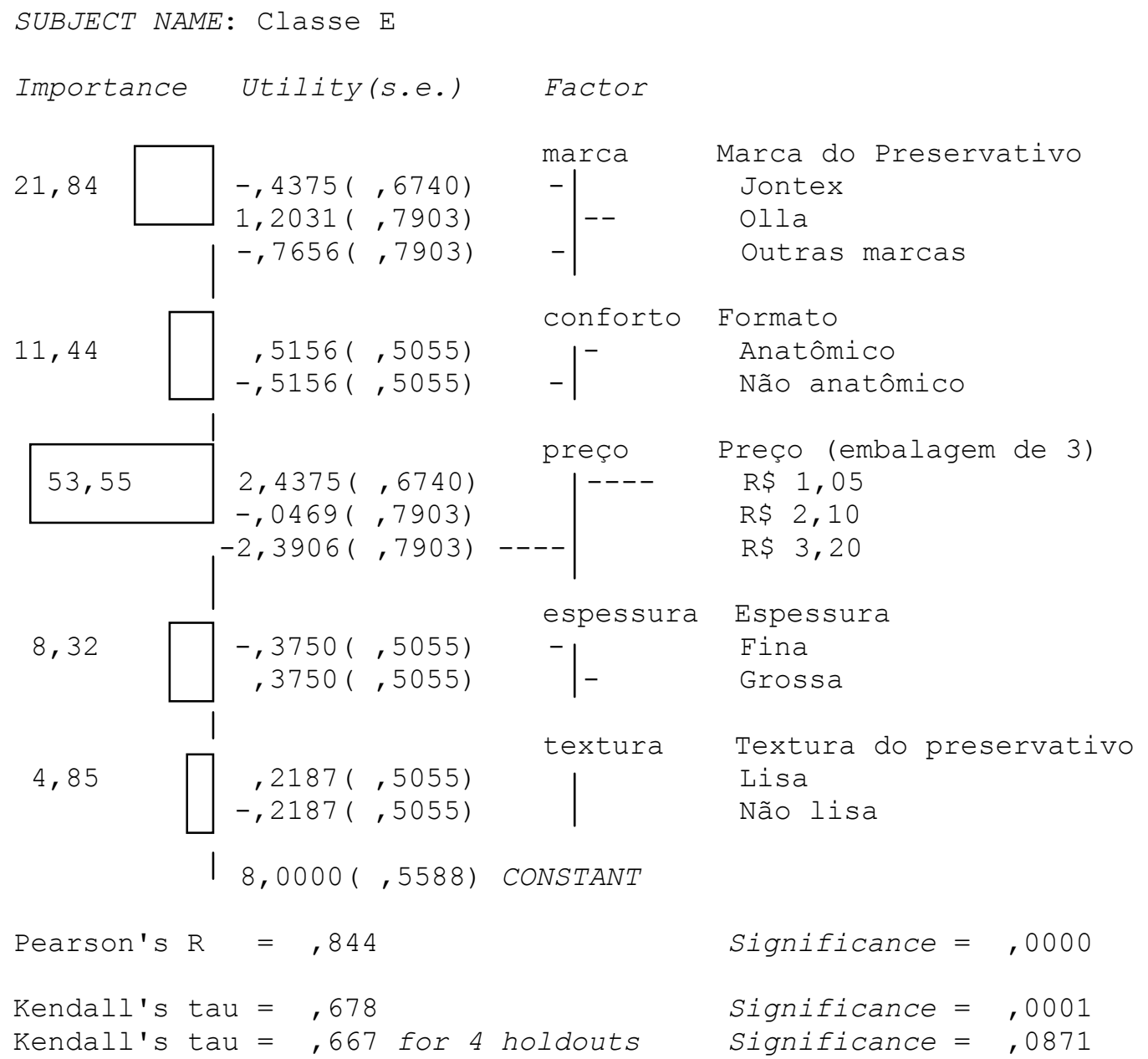


Figura 14 - Saída numérica do programa - sumário geral (média)

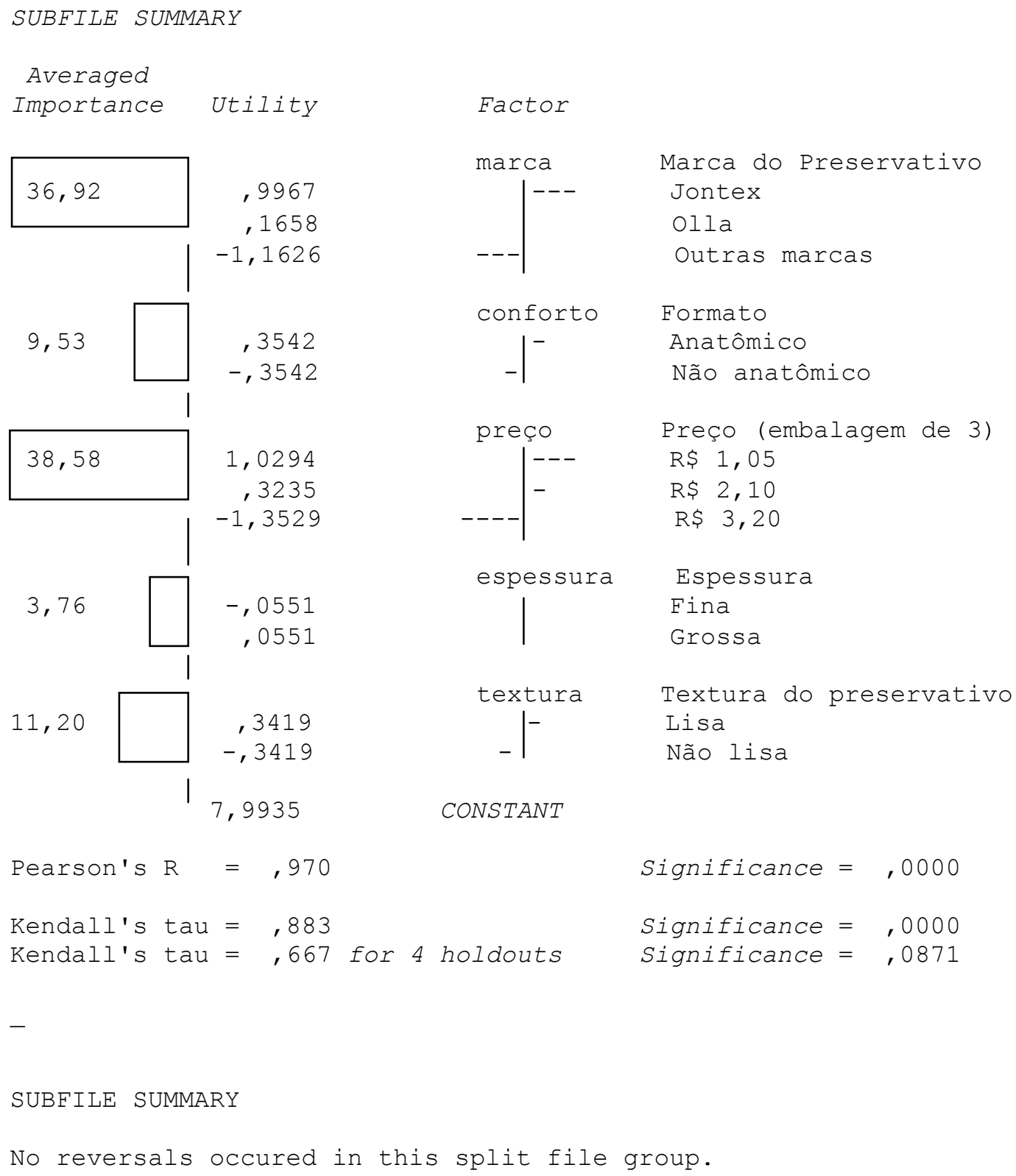

SUBFILE SUMMARY

No reversals occured in this split file group. 


\subsection{COMENTÁRIOS}

1. Analisando-se os resultados para cada uma das classes econômicas, bem como para a média (sumário geral), o coeficiente $\mathrm{R}$ de Pearson e o de Kendall são considerados altos (próximos de 1), indicando consistência entre o ranking dos conceitos e a previsão do modelo.

2. Na avaliação da importância pela média (Figura14), os dois fatores considerados como de maior peso pelos entrevistados de baixa renda são o preço, com 38,58\% da preferência, e a marca, com 36,92\%, seguidos com maior distância pela textura $(11,20 \%)$ e pelo formato $(9,53 \%)$. O fator espessura tem um baixo índice de importância $(3,76 \%)$. Uma visualização desses dados pode ser obtida no gráfico 33 .

Gráfico 33 - Resumo geral da importância média dos atributos ou fatores

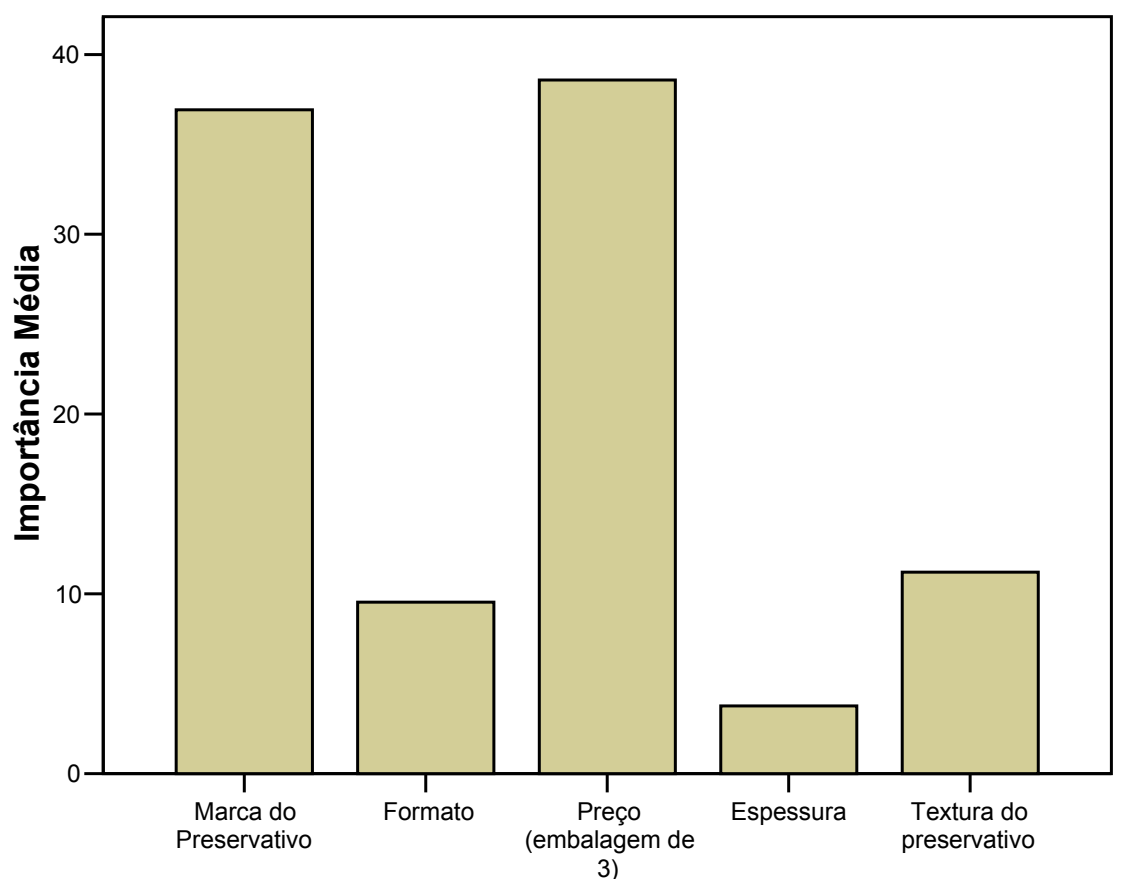

Por classes (Figuras 11, 12 e 13), apesar de as proporções de cada uma delas na amostra não corresponder estatisticamente à da população, conforme já enfatizado, os resultados sugerem que, diferentemente dos respondentes da $\mathrm{C}$, que dão maior peso à marca que ao preço (42,84\% contra $30,64 \%$ da importância), os das classes D e E invertem sua preferência, carregando importância ao preço (52,25\% e 53,55\%, respectivamente). Mais que 
nas demais classes, observa-se para os entrevistados da D uma maior valorização da textura $(14,46 \%$ da importância total) e uma irrelevante consideração ao fator formato. Esse quadro é visualizado no gráfico 34 .

Gráfico 34 - Importância média dos atributos por classe econômica

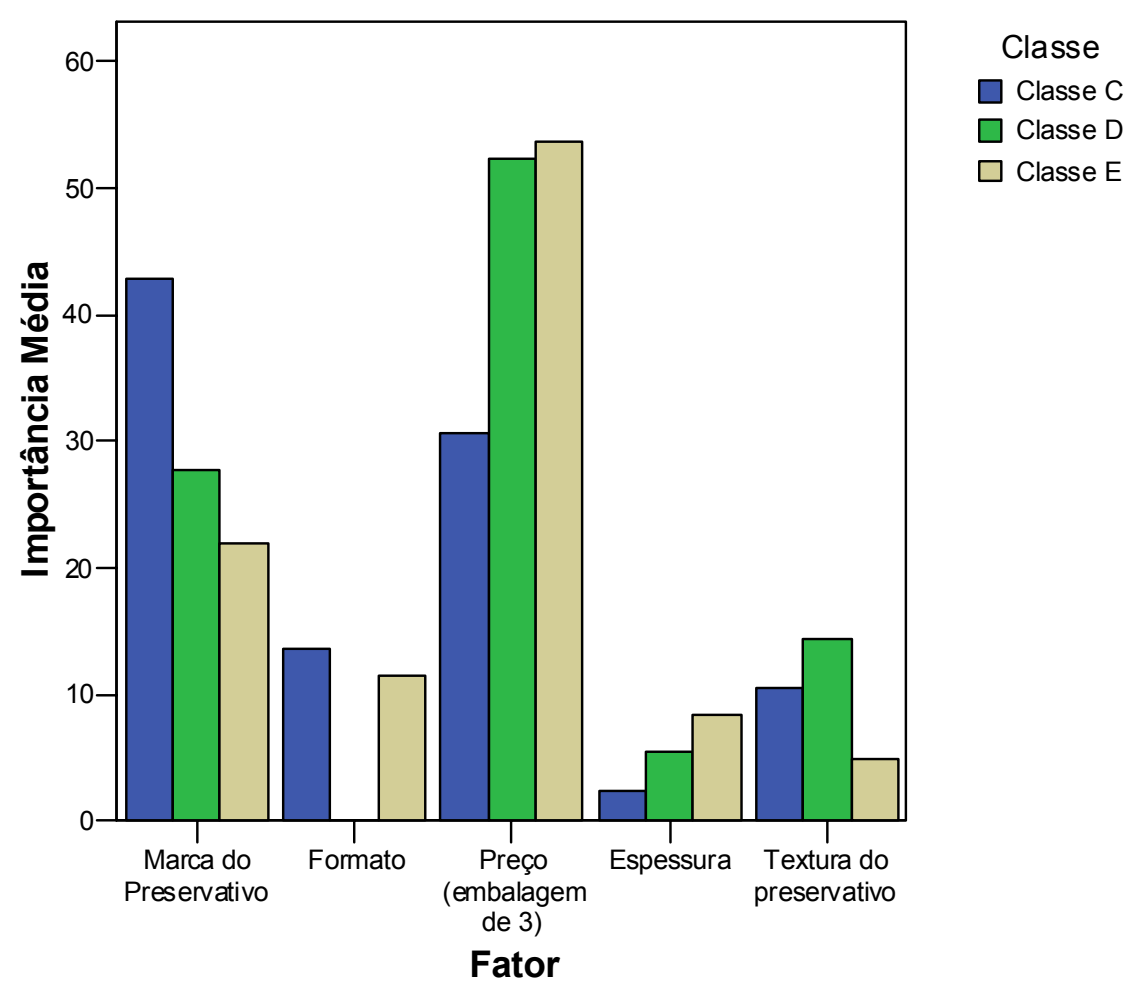

3. Quanto às utilidades dos níveis dos fatores, os resultados obtidos sugerem:

a-) Para o fator marca, é nítida a maior preferência por Jontex e a forte rejeição de outras marcas que não Olla e Jontex, na avaliação média de utilidade, conforme se observa no gráfico 35. Por classe, o gráfico 36 mostra uma aceitação predominante de Jontex pelos respondentes da classe $\mathrm{C}$, da mesma forma que Olla pelos respondentes da classe $\mathrm{E}$. Os entrevistados da classe D também preferem Jontex, mas em menor nível que os da classe C. A rejeição da marca Olla pelos respondentes da classe D é notável, bem como a rejeição de outras marcas pelos respondentes das classes $\mathrm{C}$ e $\mathrm{E}$. 
Gráfico 35 - Utilidades dos níveis do atributo marca, pela avaliação média

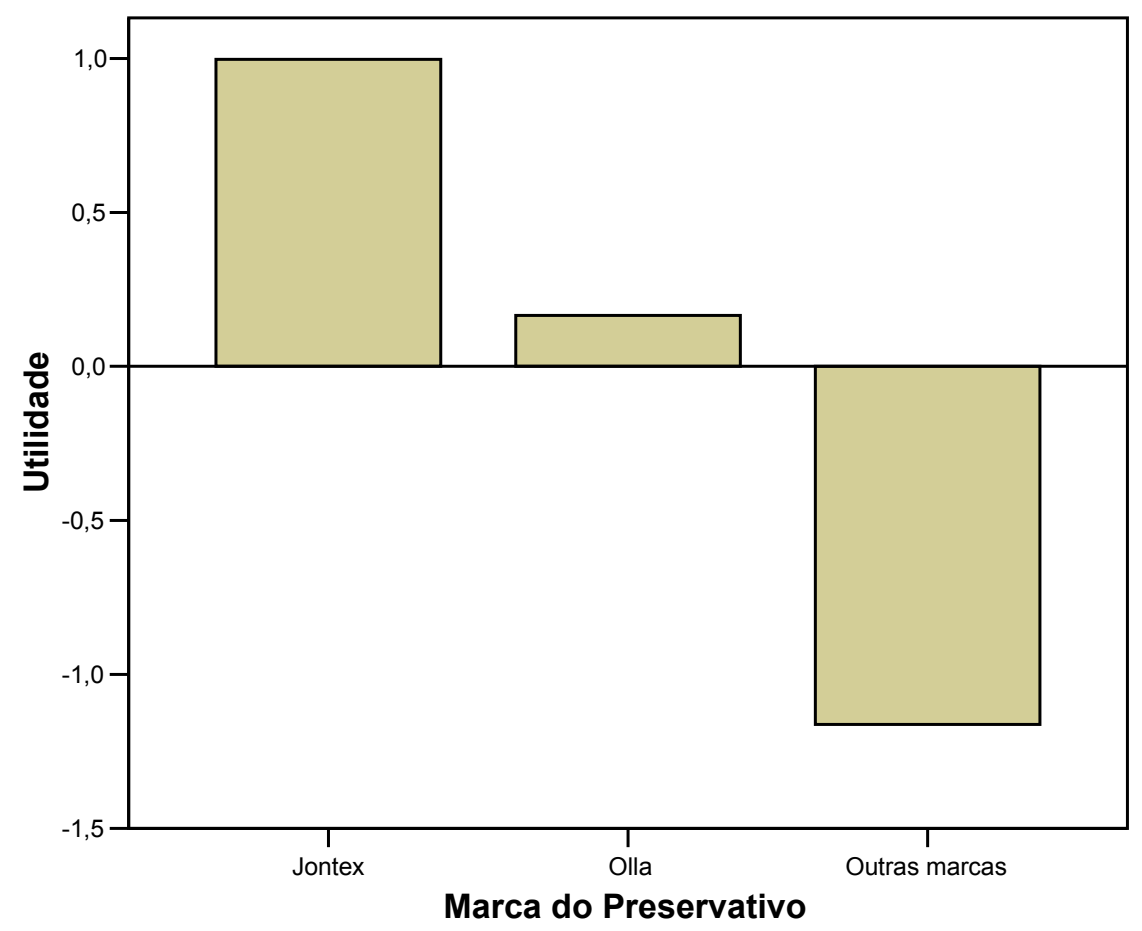

Gráfico 36 - Utilidades dos níveis do atributo marca, por classe

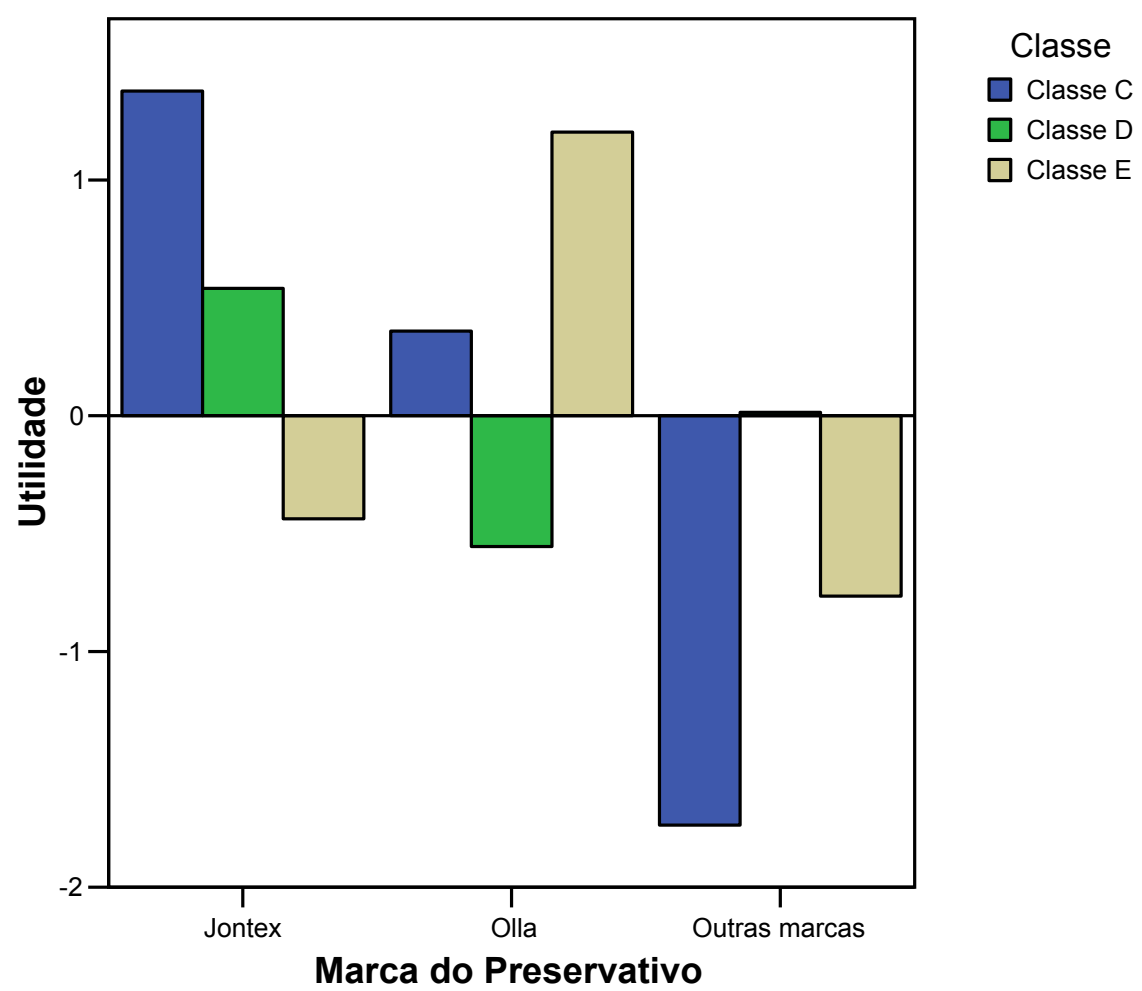


b-) A análise da importância média do fator preço traz uma informação importante, à medida que se detecta uma rejeição do preço máximo de $\mathrm{R} \$ 3,20$ em análise. Esse aspecto é facilmente visualizado no gráfico 37.

$\mathrm{Na}$ avaliação por classes, como esperado, o preço mais baixo (R\$ 1,05) tem a preferência de todos os entrevistados, mais fortemente dos da classe E. O preço intermediário de R\$ 2,10 ainda é aceito pelos respondentes da classe C, em uma escala menor, mas já rejeitado pelos das outras classes. O preço máximo é descartado pelos entrevistados de todas as classes. Isso pode ser observado no gráfico 38.

Gráfico 37 - Utilidades dos níveis do atributo preço, pela avaliação média

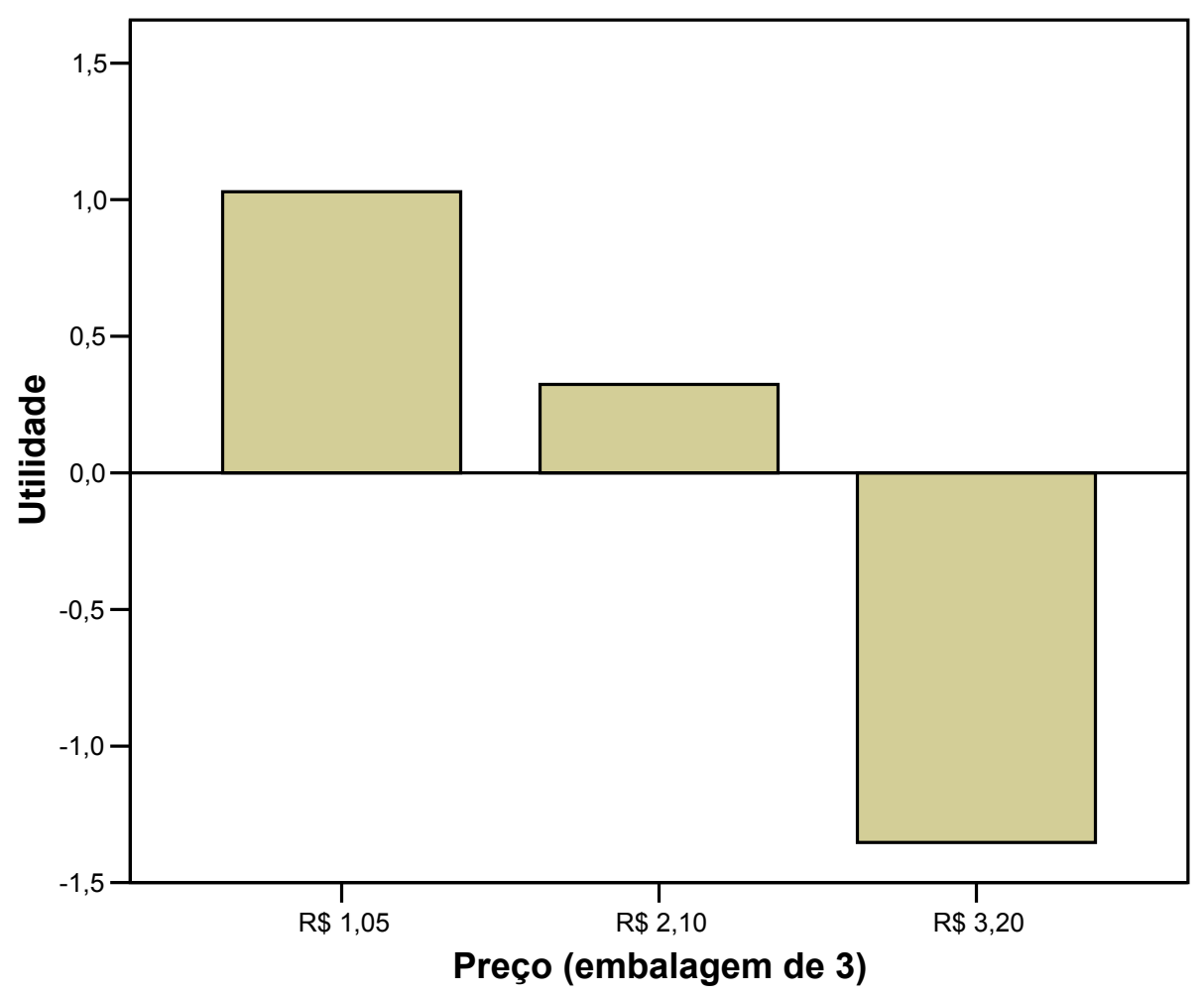


Gráfico 38 - Utilidades dos níveis do atributo preço, por classe

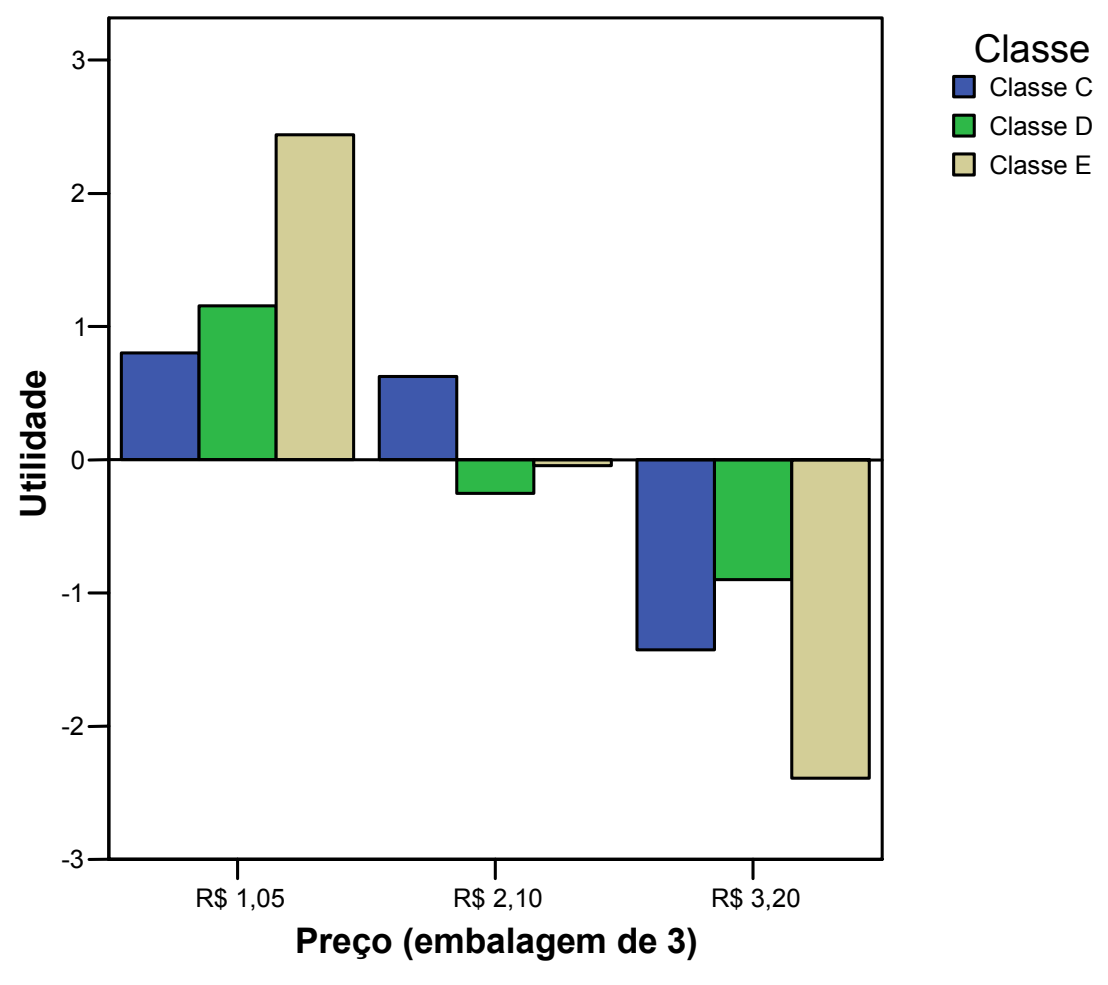

c-) O fator formato, quando avaliado pela média, mostra que a preferência absoluta é pelo nível anatômico (gráfico 39), o que se confirma nas repostas por classe, exceto para os entrevistados da classe D, que não registram preferência (gráfico 40). 
Gráfico 39 - Utilidades dos níveis do atributo formato, pela avaliação média

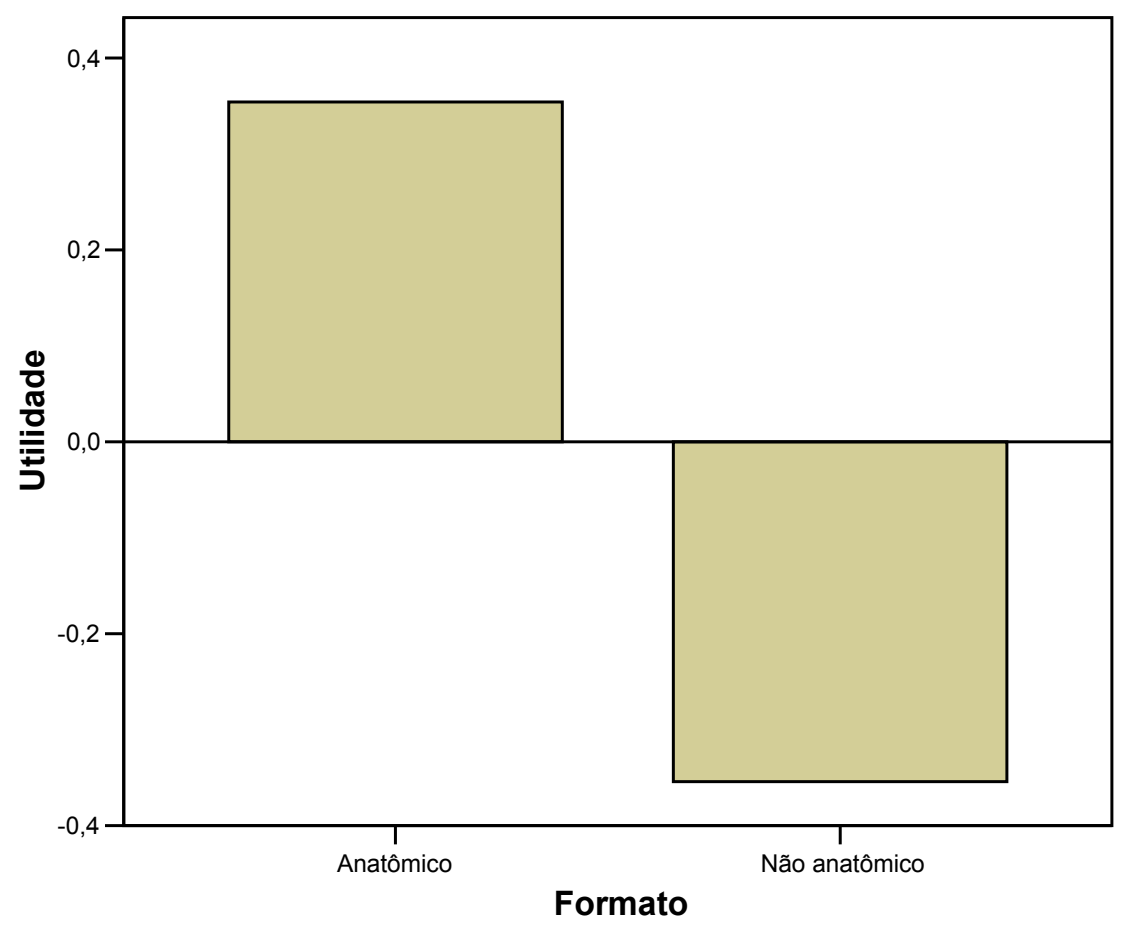

Gráfico 40 - Utilidades dos níveis do atributo formato, por classe

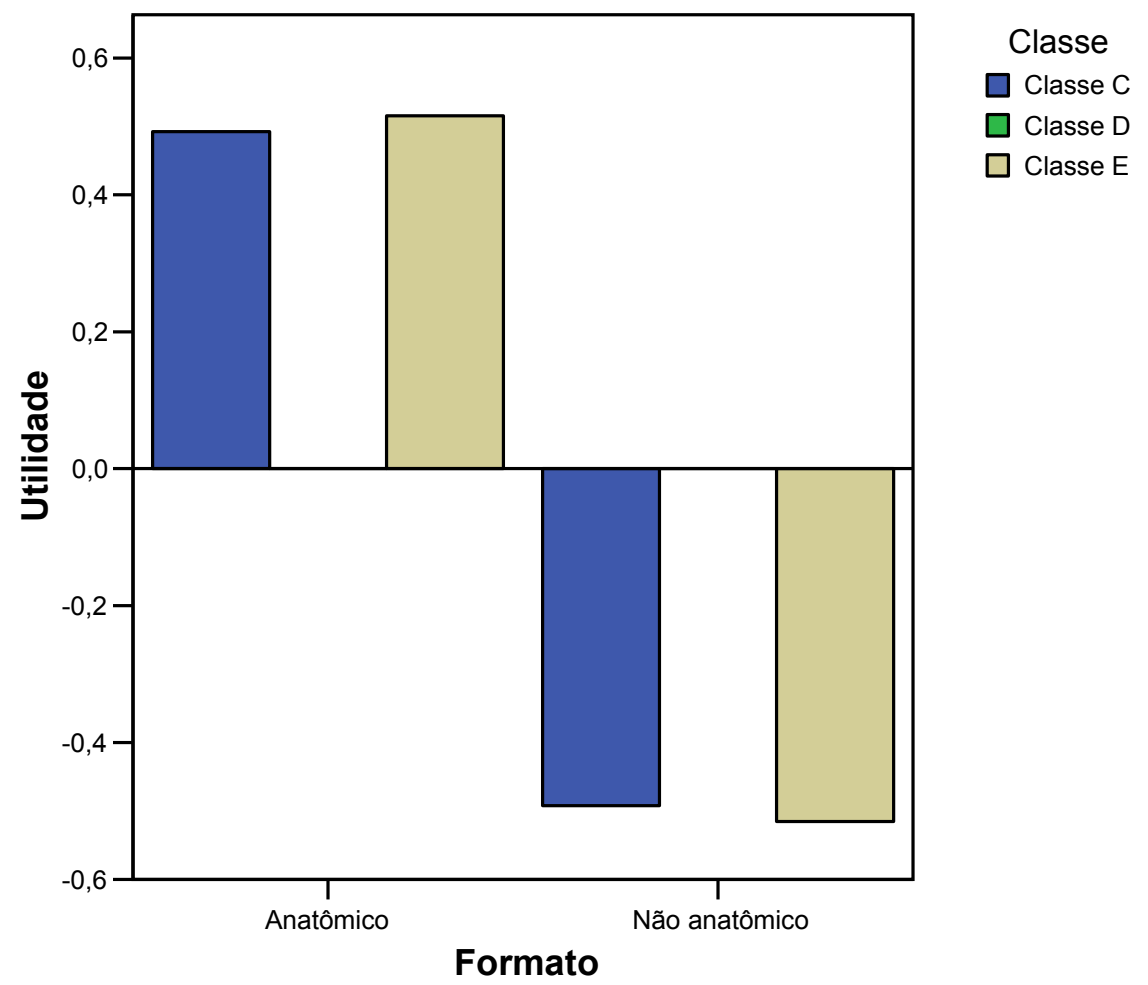


d-) Na média de importância, os níveis de atributos espessura fina e textura não lisa são rejeitados pelos respondentes (gráfico 41 e 42). No entanto, chamam atenção as respostas dos indivíduos da classe D no atributo espessura, que invertem os valores e apresentam rejeição à do tipo grosso (gráfico 43).

Gráfico 41 - Utilidades dos níveis do atributo espessura, pela avaliação média

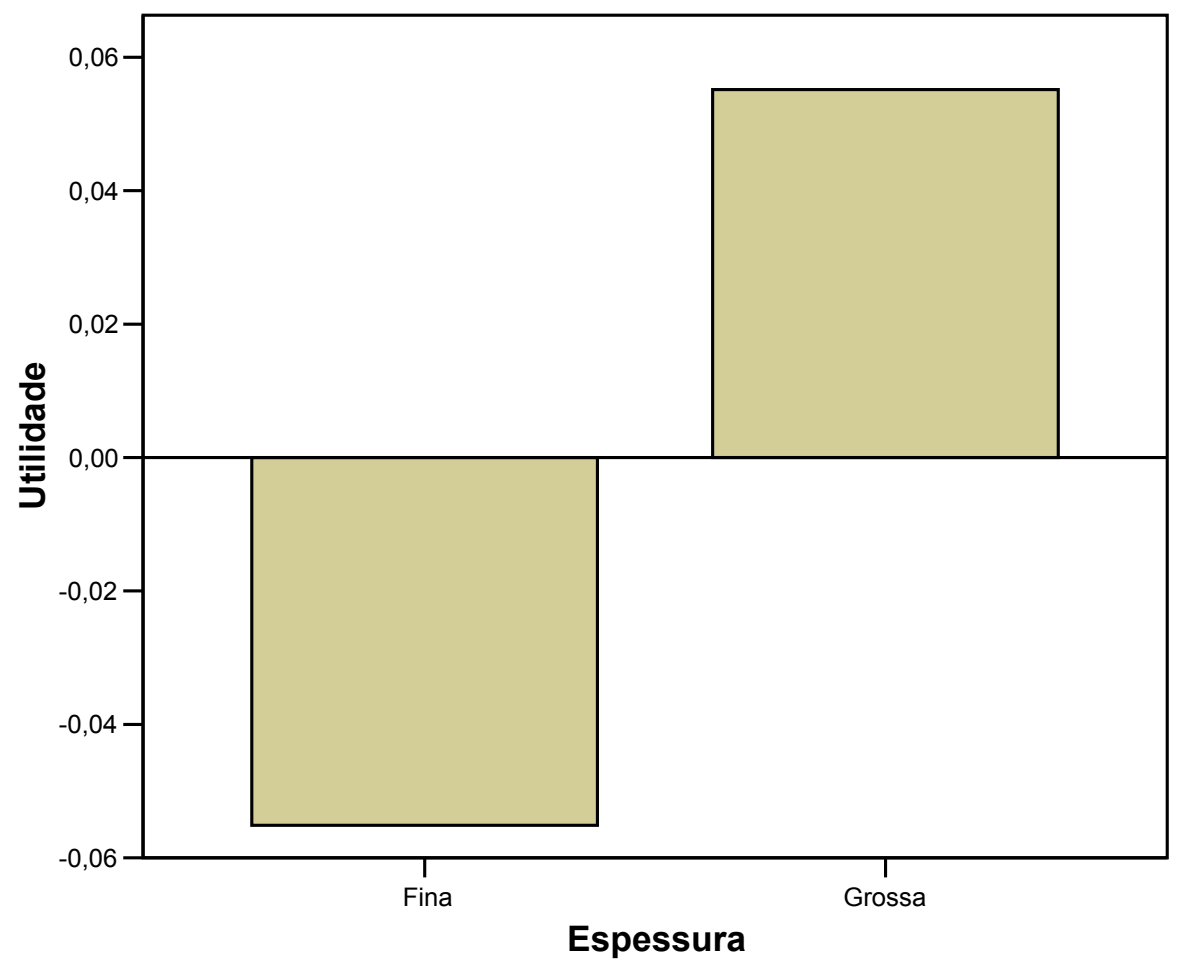


Gráfico 42 - Utilidades dos níveis do atributo textura, pela avaliação média

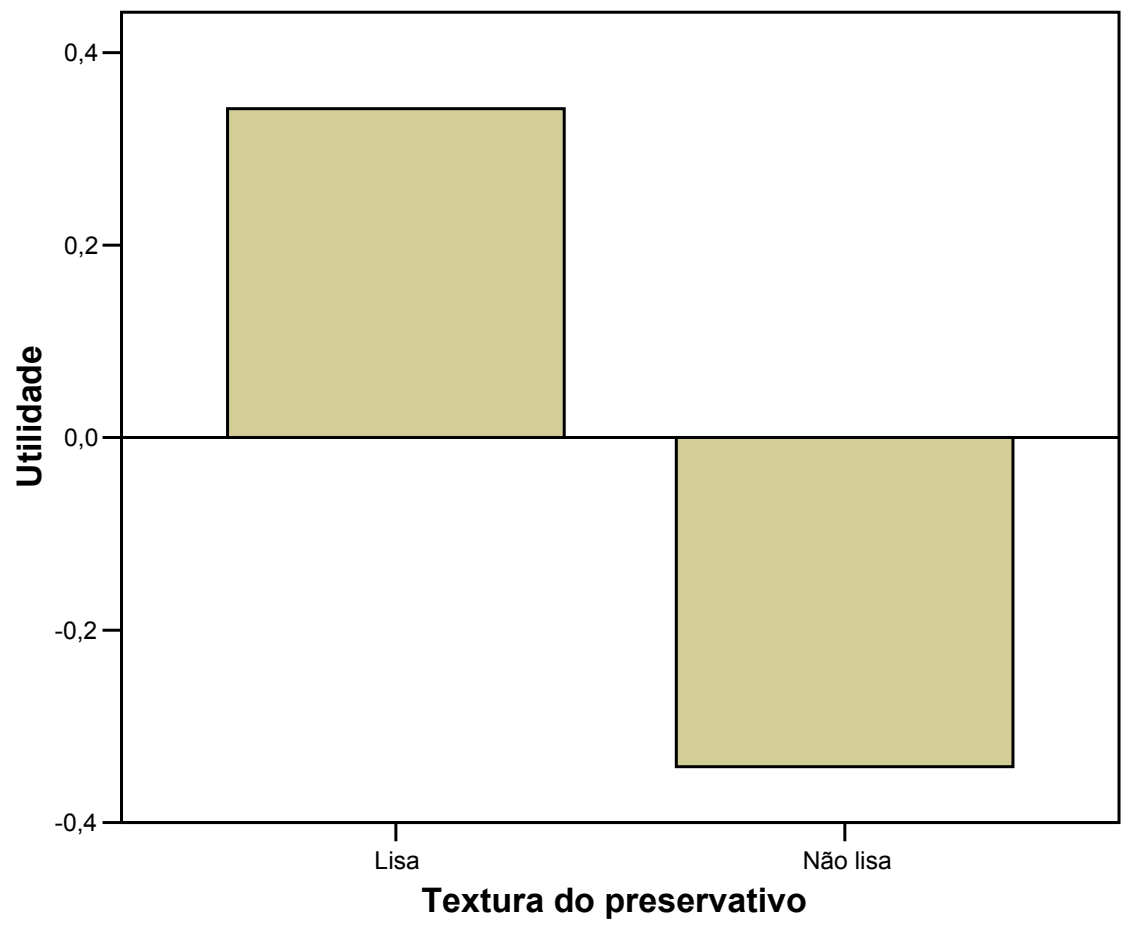

Gráfico 43 - Utilidades dos níveis do atributo espessura, por classe

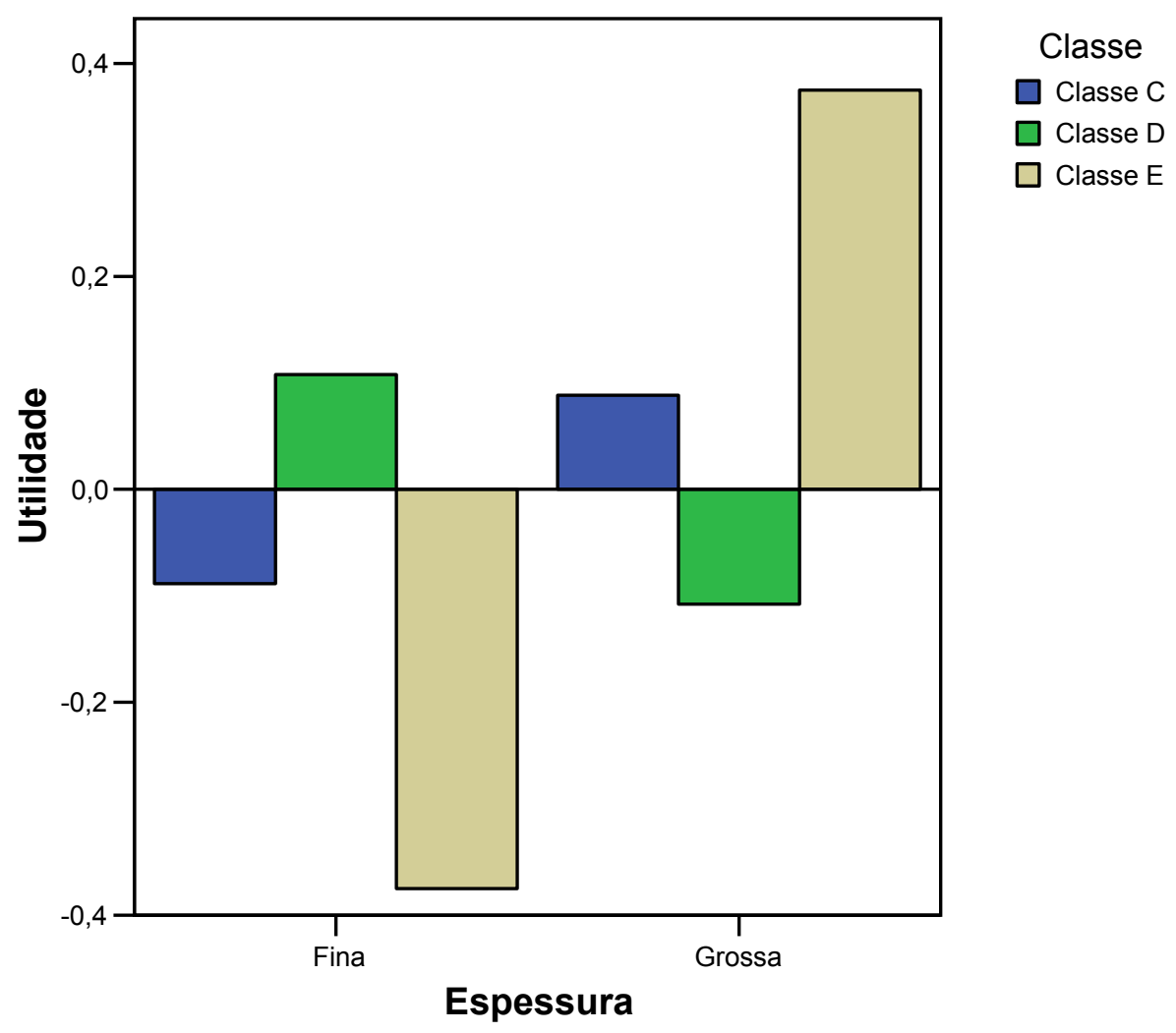




\subsection{AGRUPAMENTO POR FAIXA DE IDADE - COMENTÁRIOS}

$\mathrm{Na}$ tentativa de explorar uma outra vertente que também pode enriquecer a análise, o trabalho não se limitou apenas aos resultados advindos do agrupamento por classes econômicas. O processamento da conjoint também foi planejado para dar respostas em um outro nível de grupo, agora o das faixas de idade, isto é, os dados dos indivíduos pertencentes a determinada faixa etária foram agrupados e os resultados foram gerados nesse nível. Para tanto, em primeiro lugar, por meio do procedimento recode do SPSS, foi criada uma nova variável, resultado do rearranjo da variável idade por faixas etárias. Assim, a nova variável, denominada $f x \_i d$ assumiu valor 1 para o intervalo de 18 a 27 anos, 2 para o de 28 a 34 anos e 3 para o de 35 a 53 anos. Adaptou-se a sintaxe do programa para a nova variável (Apêndice D) e o seu processamento gerou novas saídas.

Novamente, como no agrupamento por classe social, salienta-se que a distribuição das faixas etárias da amostra não segue a mesma encontrada na população. O intuito de se fazer esse novo agrupamento, como comentado, foi observar a existência de tendências que pudessem chamar a atenção para futuras pesquisas mais direcionadas.

No tocante aos resultados, ressalte-se que os índices que mensuram a importância dos atributos ou fatores (coeficiente de Pearson e Kendall) mostraram-se mais uma vez próximos de $1 \mathrm{e}$, portanto, traduziram confiabilidade para os resultados. Com o intuito de tornar a análise mais clara, reuniu-se, em primeiro lugar, o conjunto de saídas com avaliações médias, mostrando que os resultados seguem as mesmas tendências verificadas no processamento anterior (agrupamento por classe), com pequenas variações nos percentuais de importância, mas na mesma ordem de grandeza, conforme pode ser constatado na figura 15 e gráficos a seguir (de 44 a 49). 
Figura 15 - Saída numérica do programa - sumário geral (média)

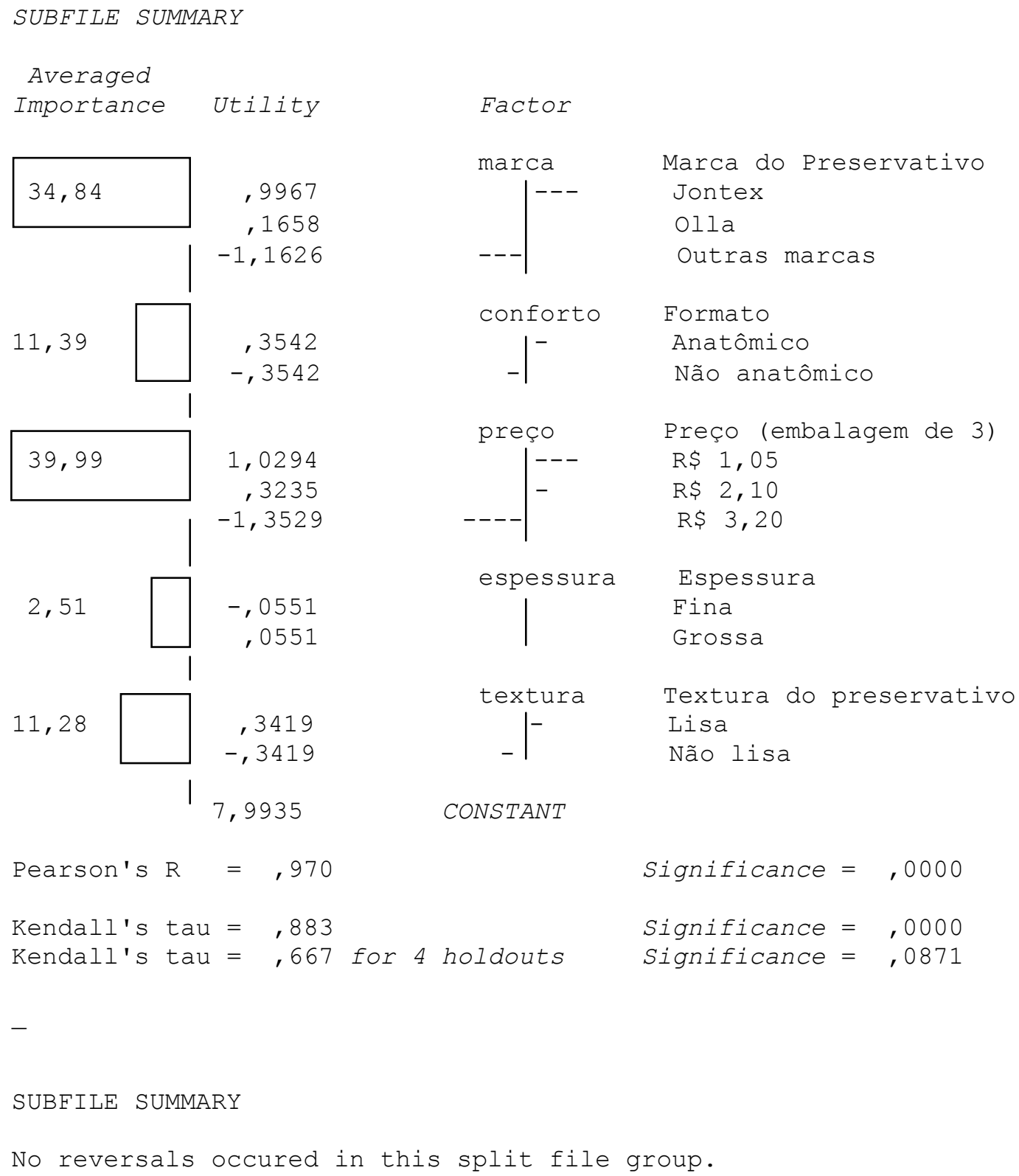


Gráfico 44 - Resumo geral da importância média dos atributos ou fatores

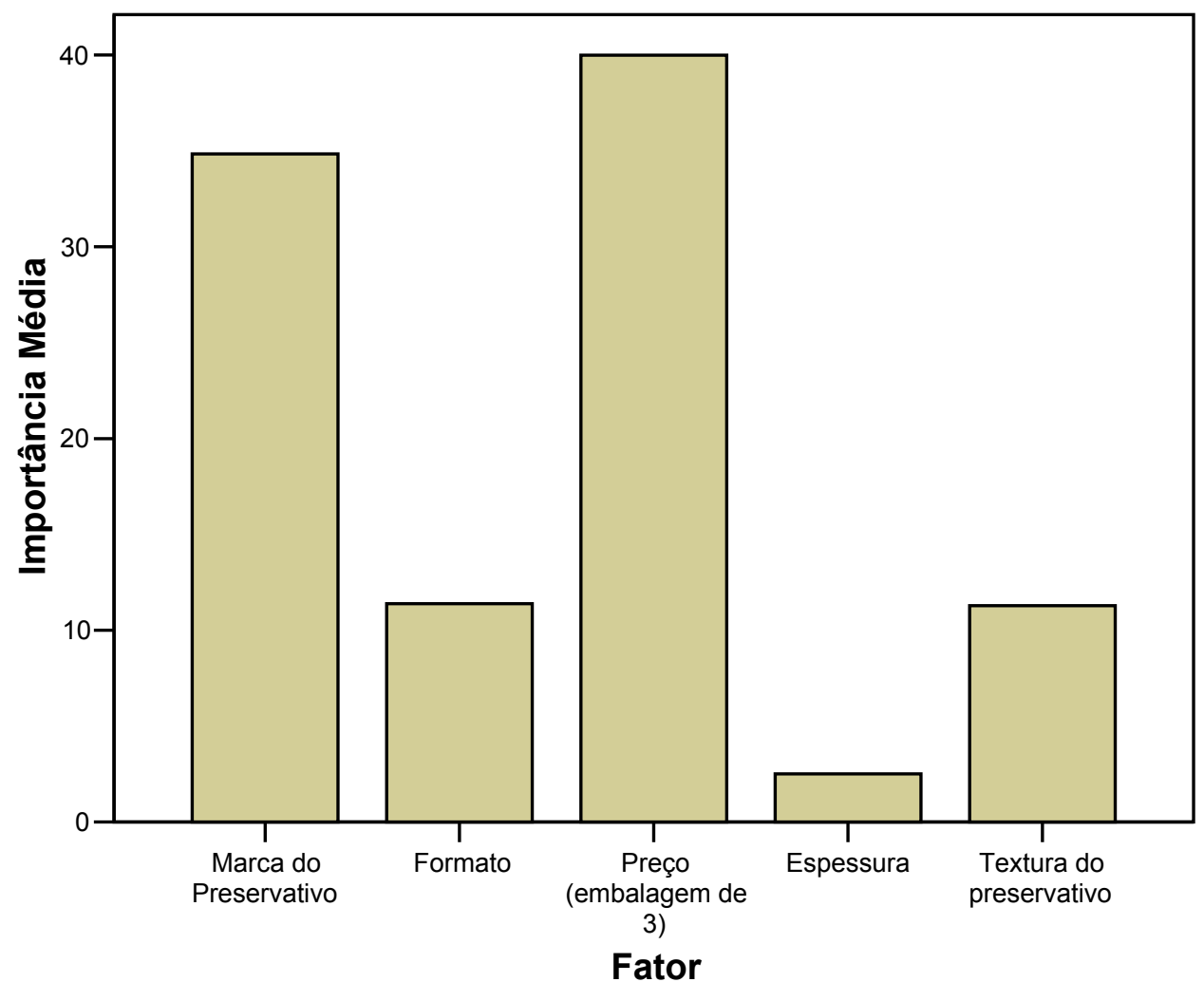

Gráfico 45 - Utilidades dos níveis do atributo marca, pela avaliação média

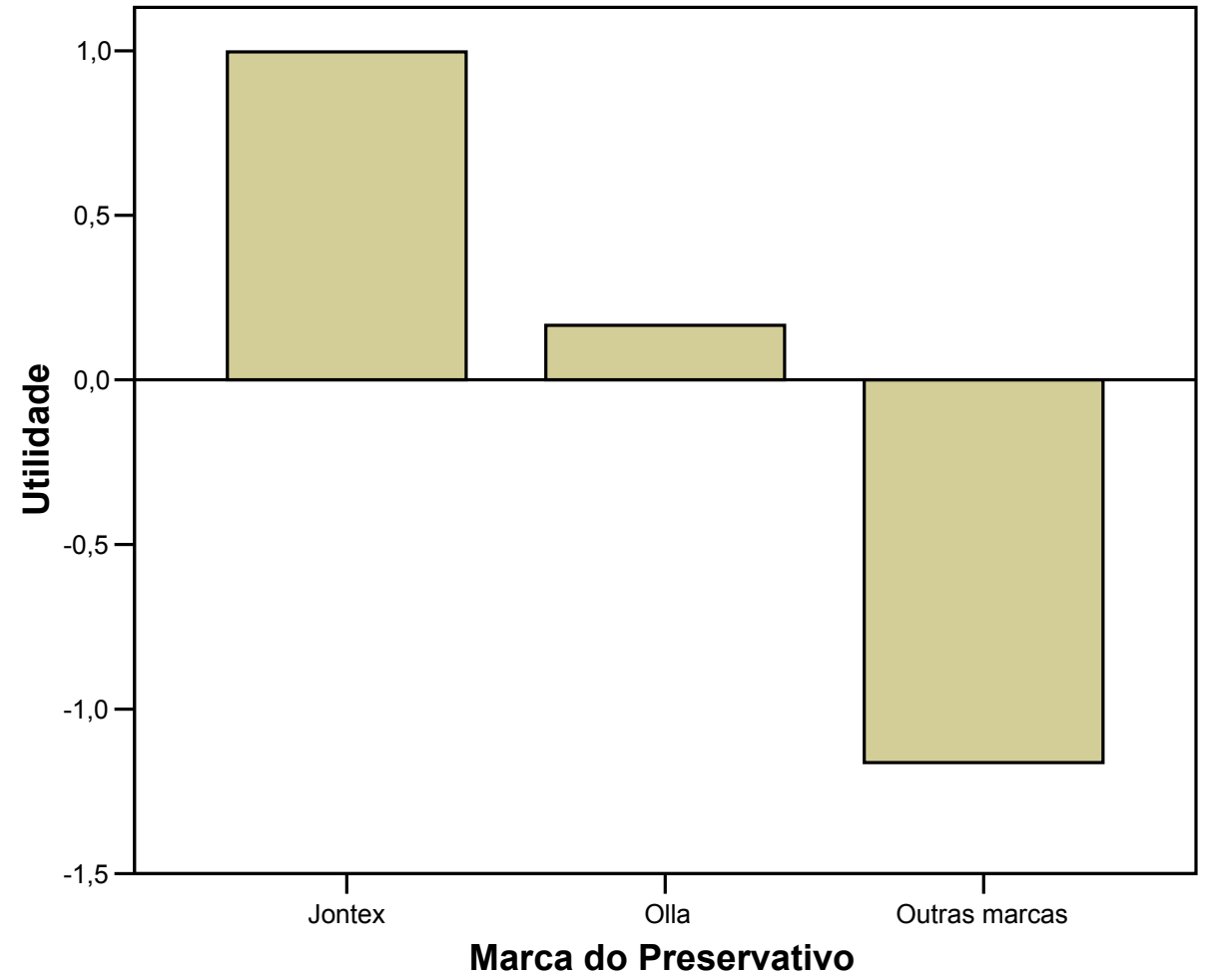


Gráfico 46 - Utilidades dos níveis do atributo preço, pela avaliação média

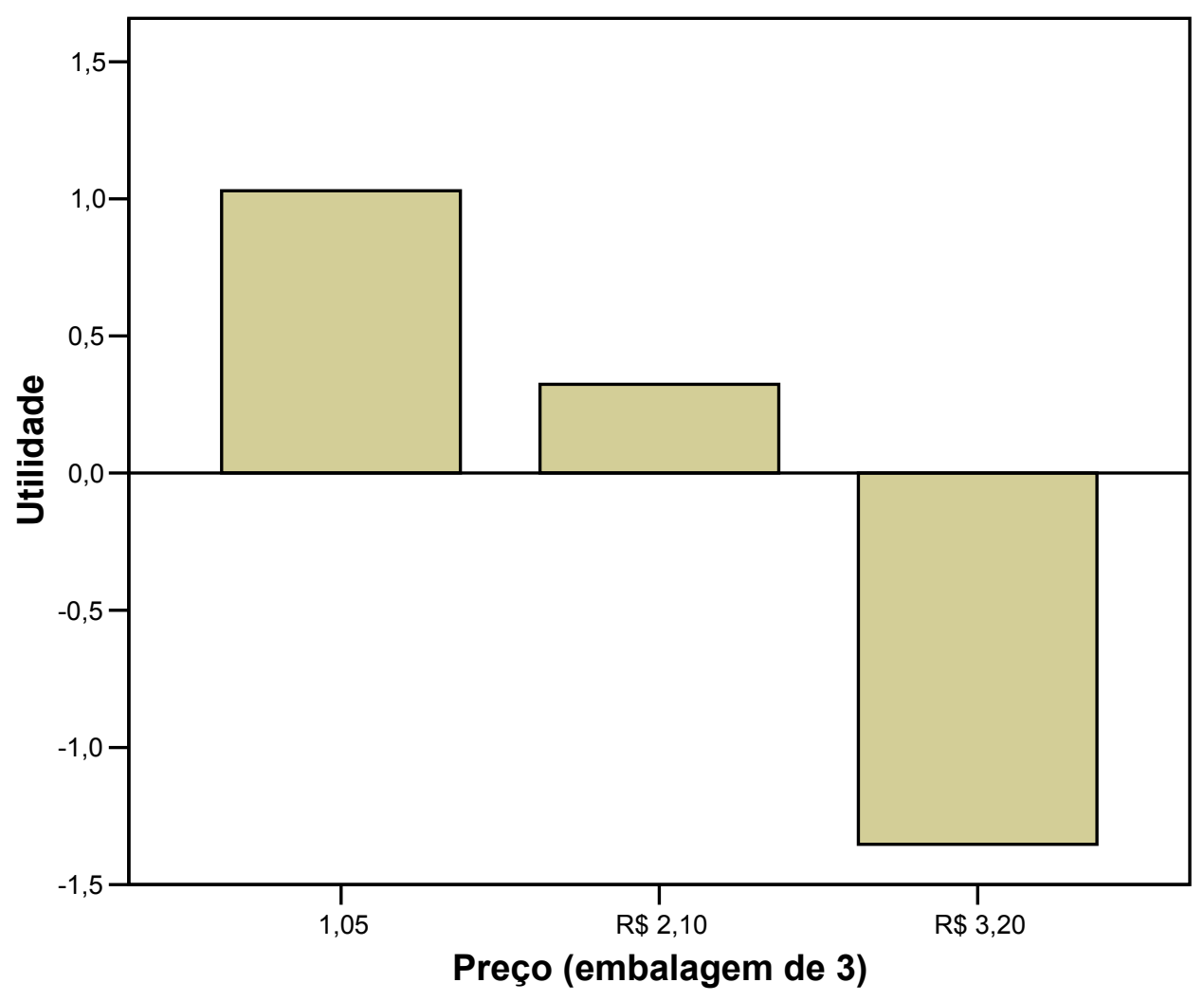

Gráfico 47 - Utilidades dos níveis do atributo formato, pela avaliação média

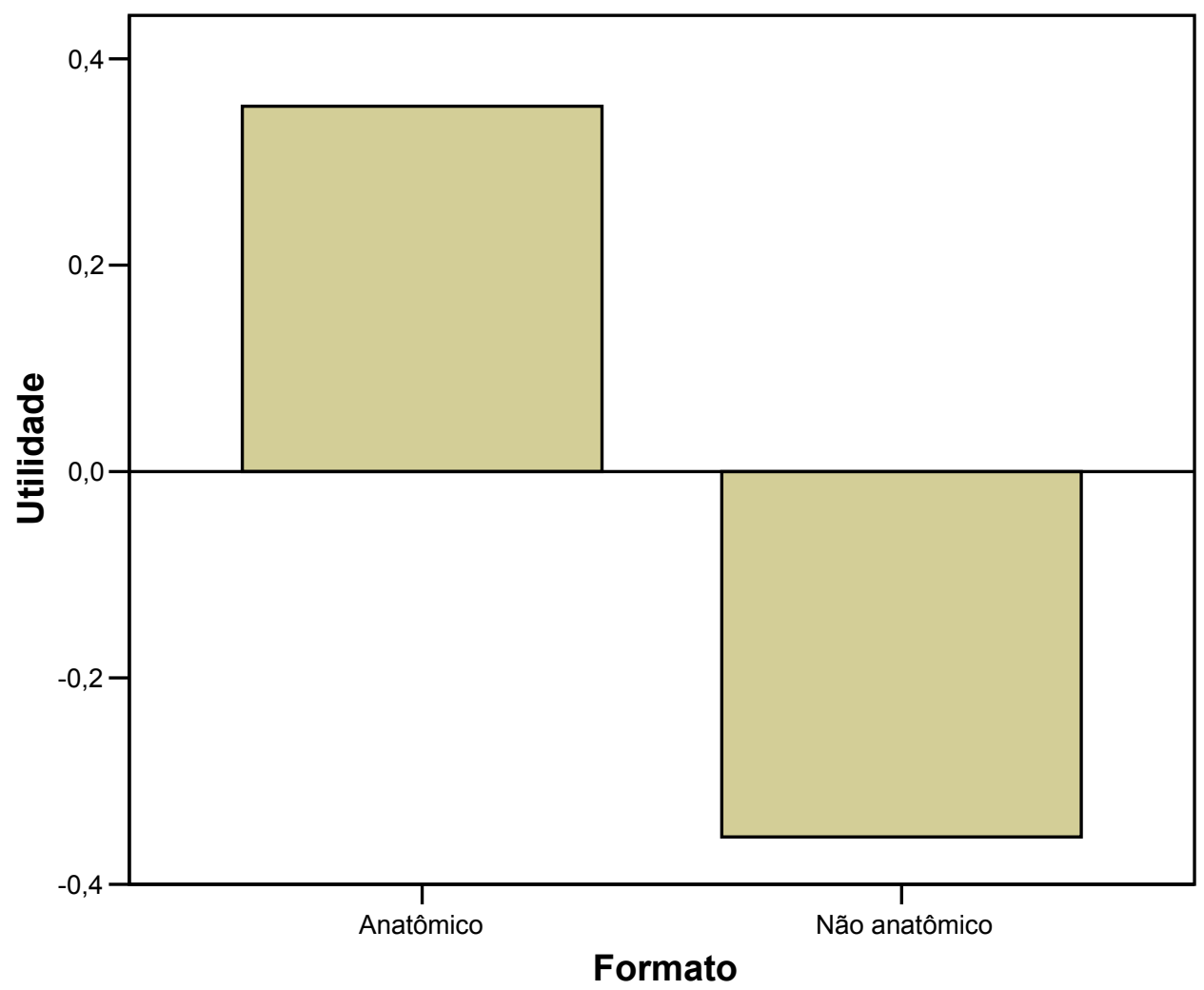


Gráfico 48 - Utilidades dos níveis do atributo espessura, pela avaliação média

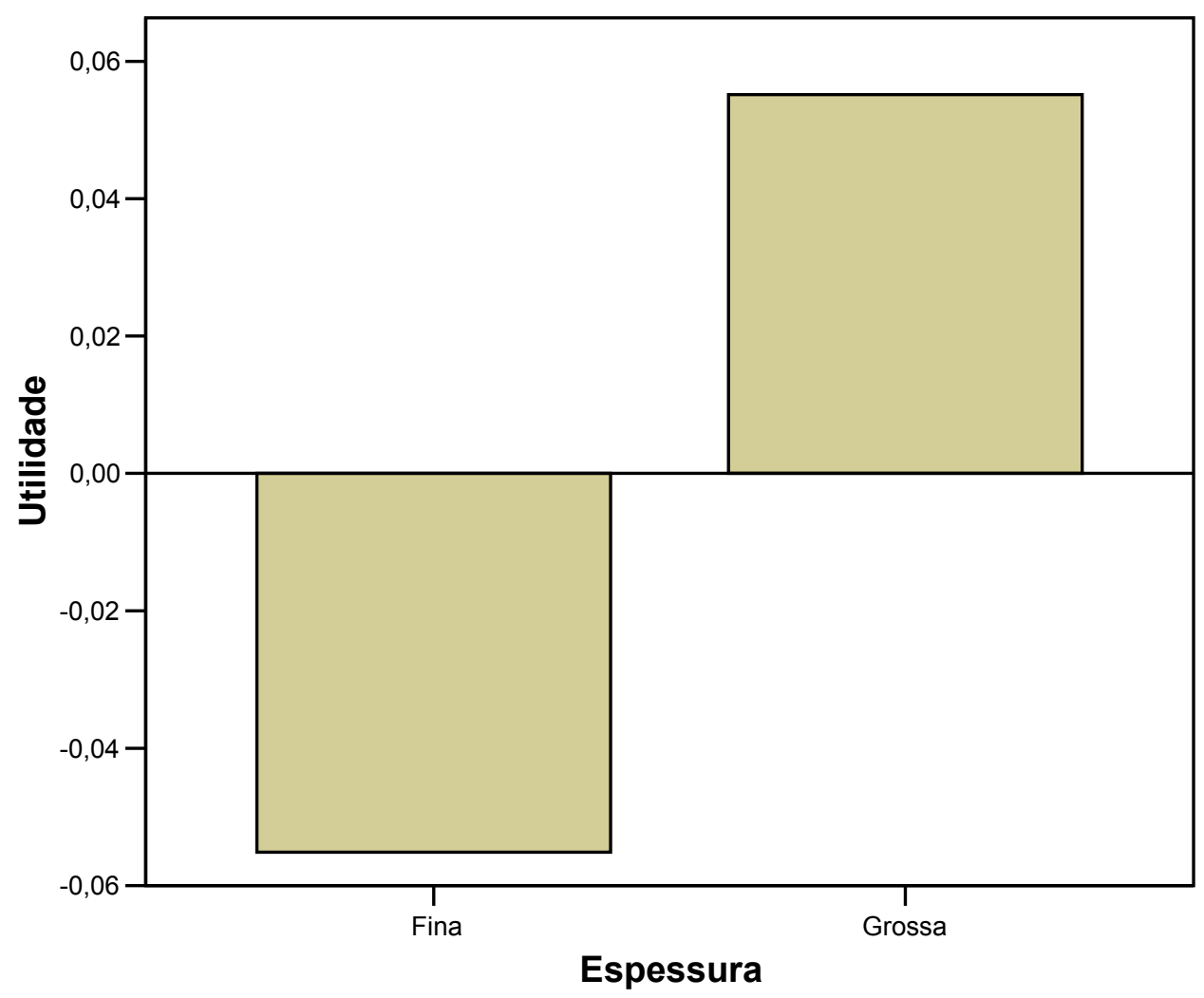

Gráfico 49 - Utilidades dos níveis do atributo textura, pela avaliação média

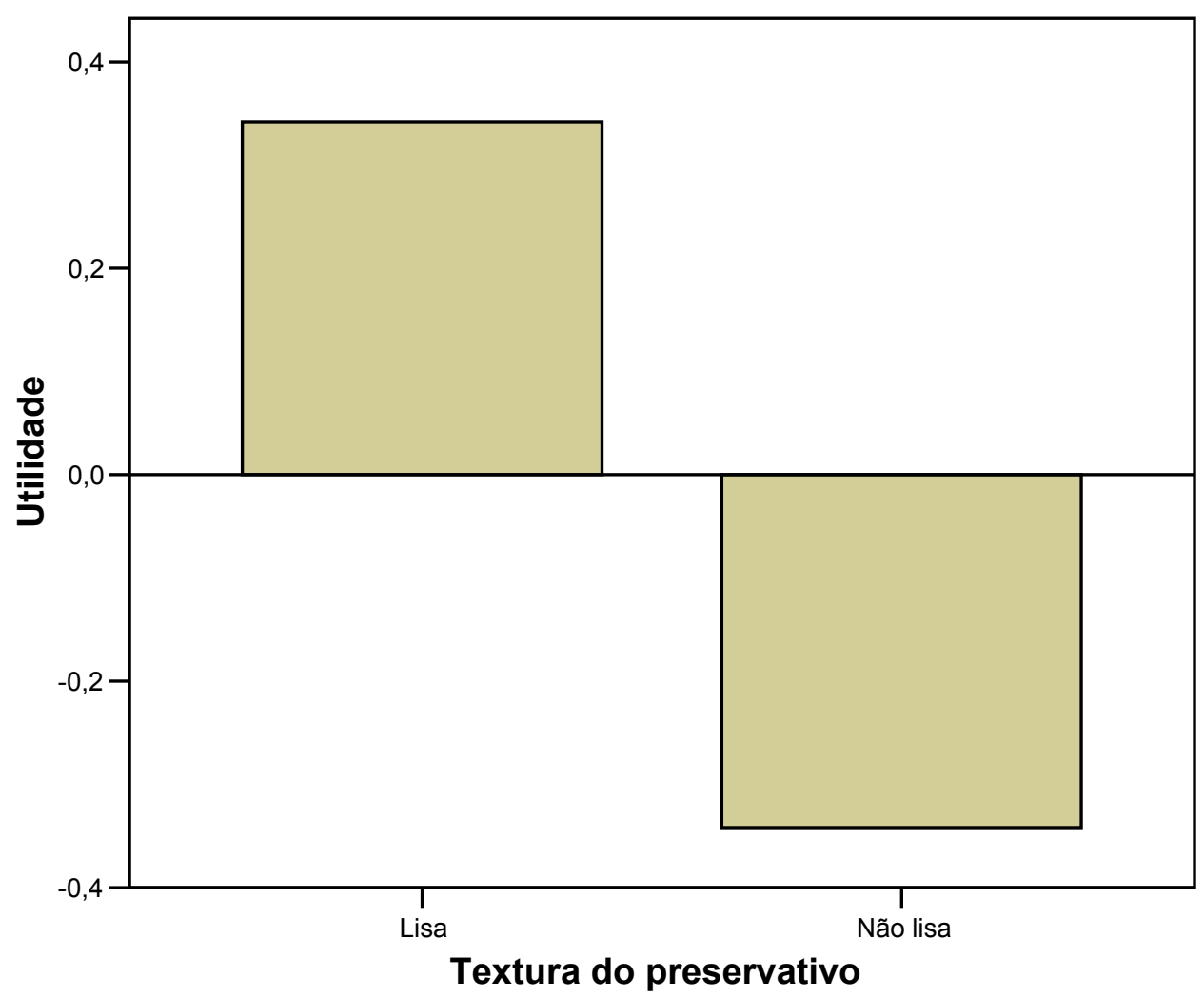


$\mathrm{Na}$ avaliação por faixa de idade, os resultados sugerem que os mais jovens (de 18 a 27 anos) atribuem uma importância muito mais significativa ao atributo marca que aos outros atributos, com quase $47 \%$ da preferência dos entrevistados. Por sua vez, os da faixa intermediária (28 a 34 anos), bem como os da faixa mais alta (35 a 53 anos) valorizam fortemente o preço, comparado aos demais fatores, com um índice de preferência ao redor de $50 \%$ cada. Ainda fazendo referência aos mais jovens, chama atenção o fato de que os percentuais de importância atribuídos ao preço nivelam-se aos do atributo textura (em torno de $18 \%$ ), seguidos de perto pelo atributo conforto (quase 14\%). Essas informações são mais bem visualizadas nas figuras 16,17 e 18 e no gráfico 50 .

Figura 16 - Saída numérica do programa por faixa de idade (faixa 1, de 18 a 27 anos)

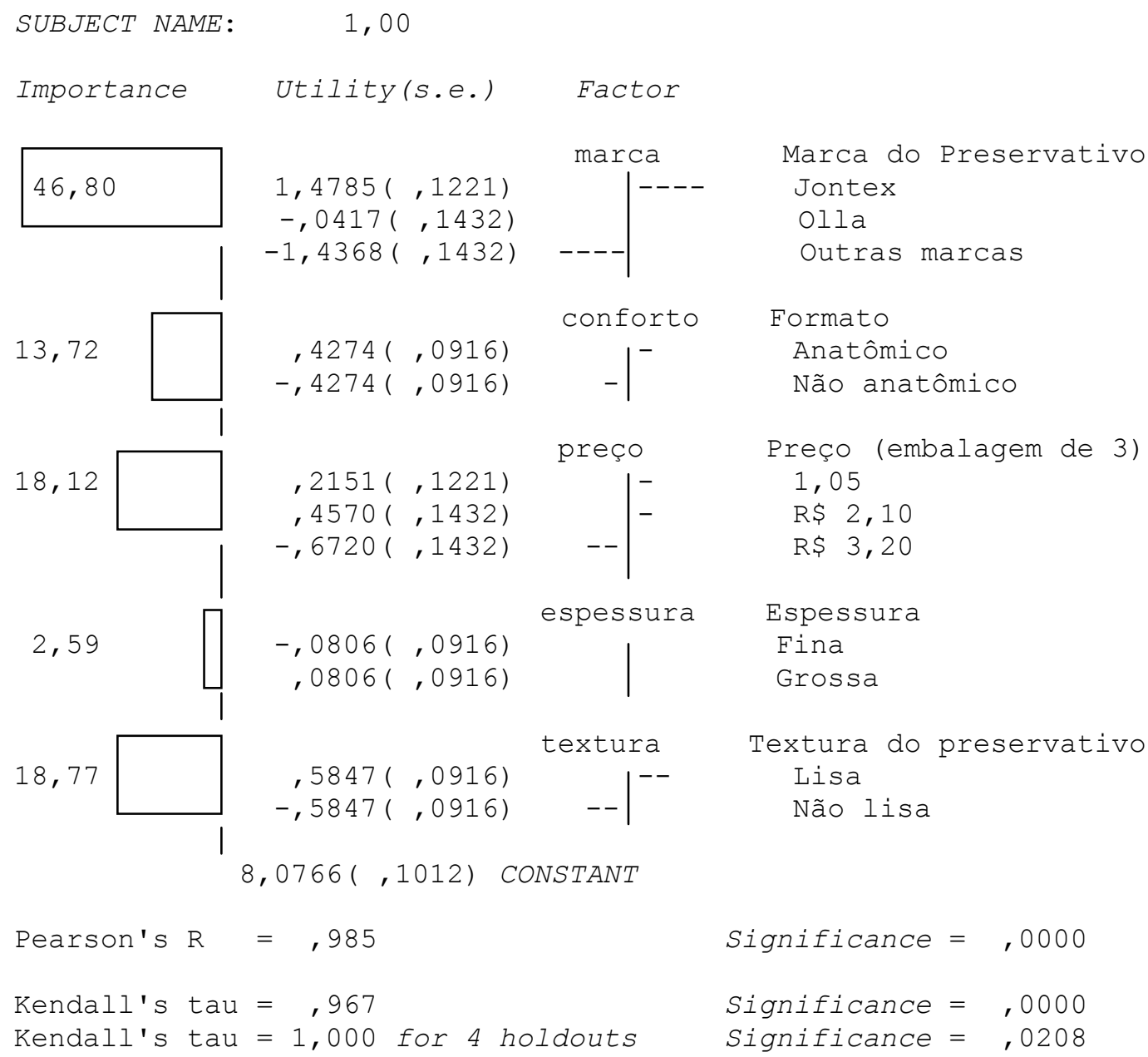


Figura 17 - Saída numérica do programa por faixa de idade (faixa 2, de 28 a 34 anos)

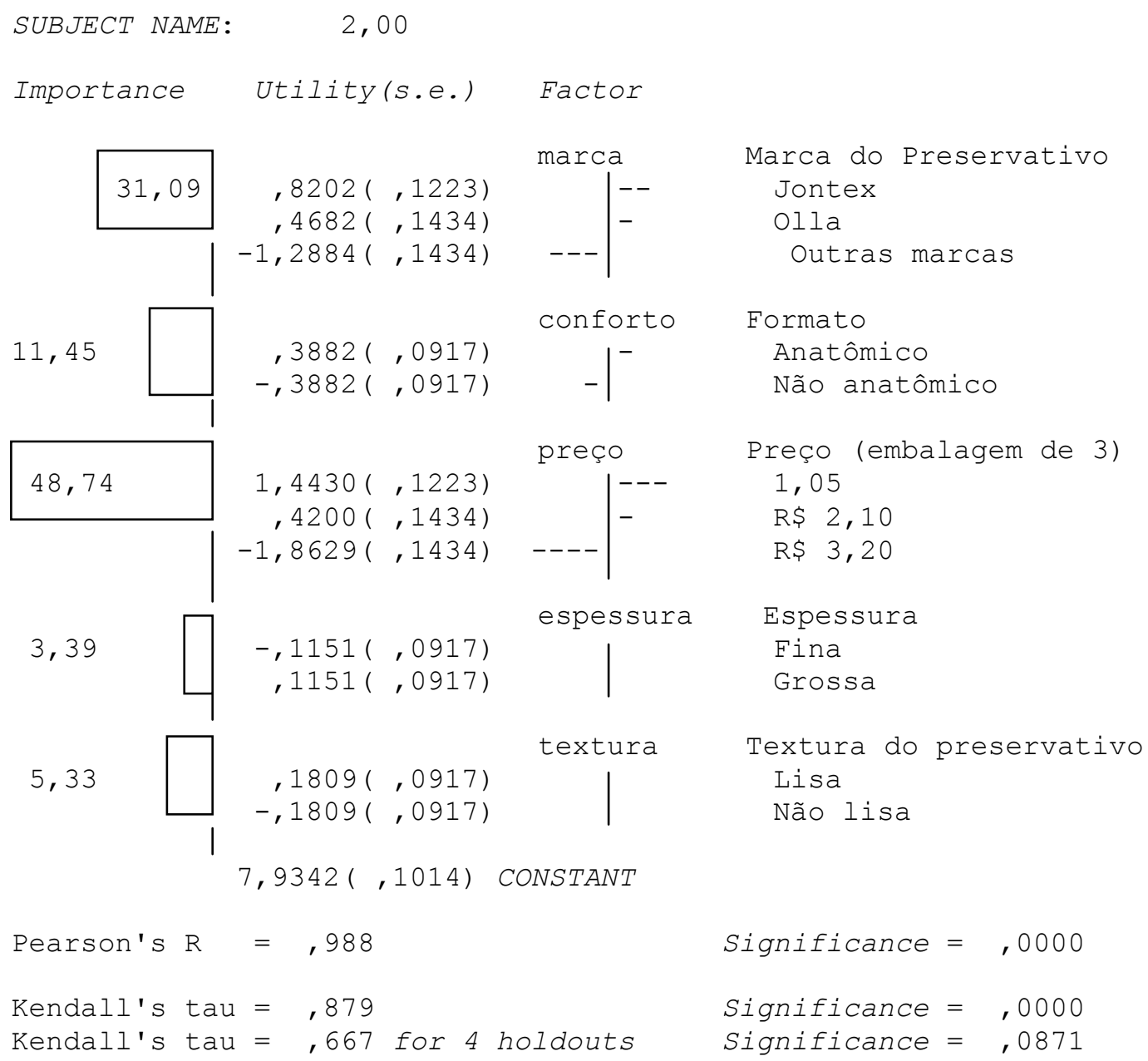


Figura 18 - Saída numérica do programa por faixa de idade (faixa 3, de 35 a 53 anos)

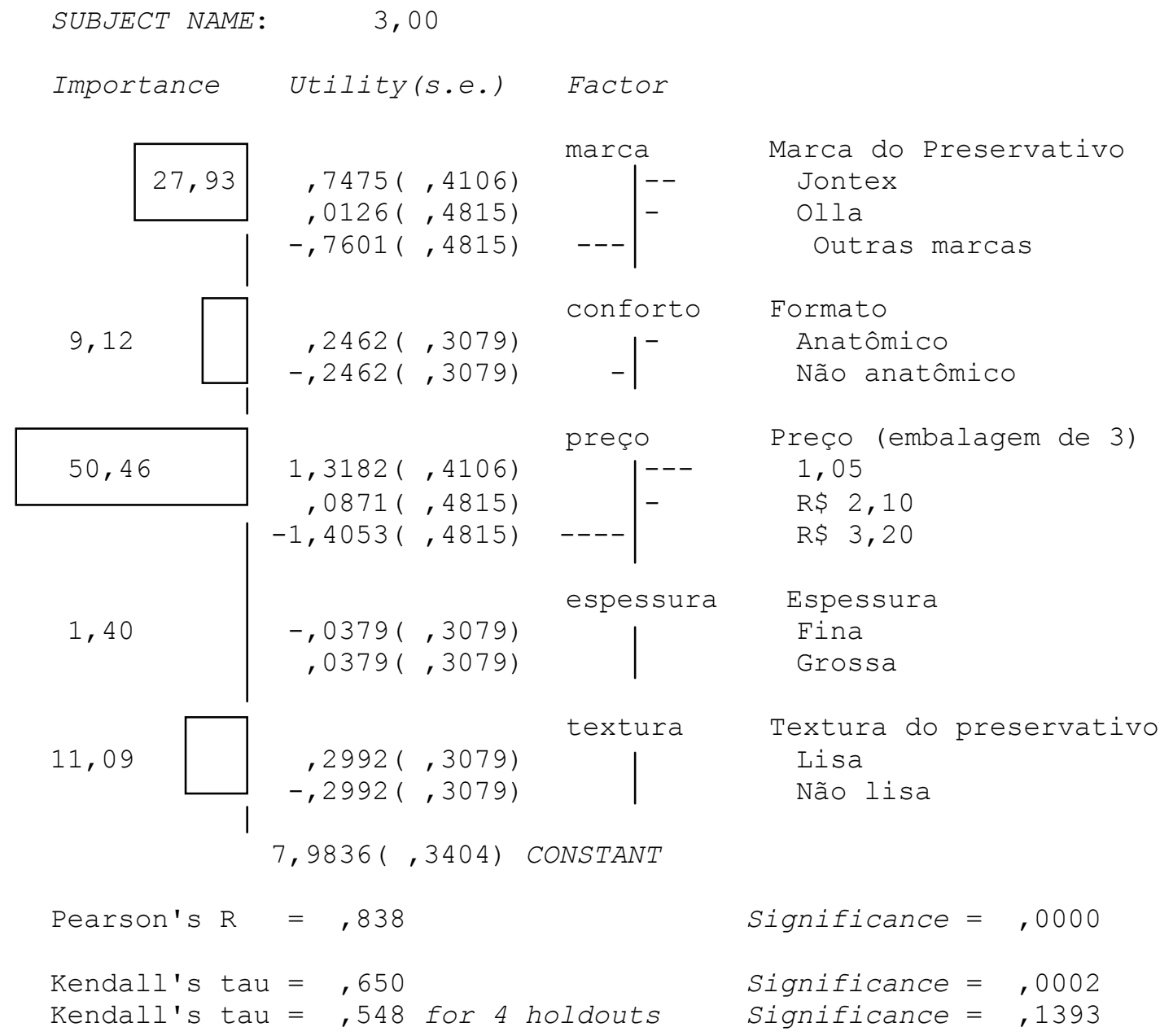


Gráfico 50 - Importância média dos atributos por faixa de idade

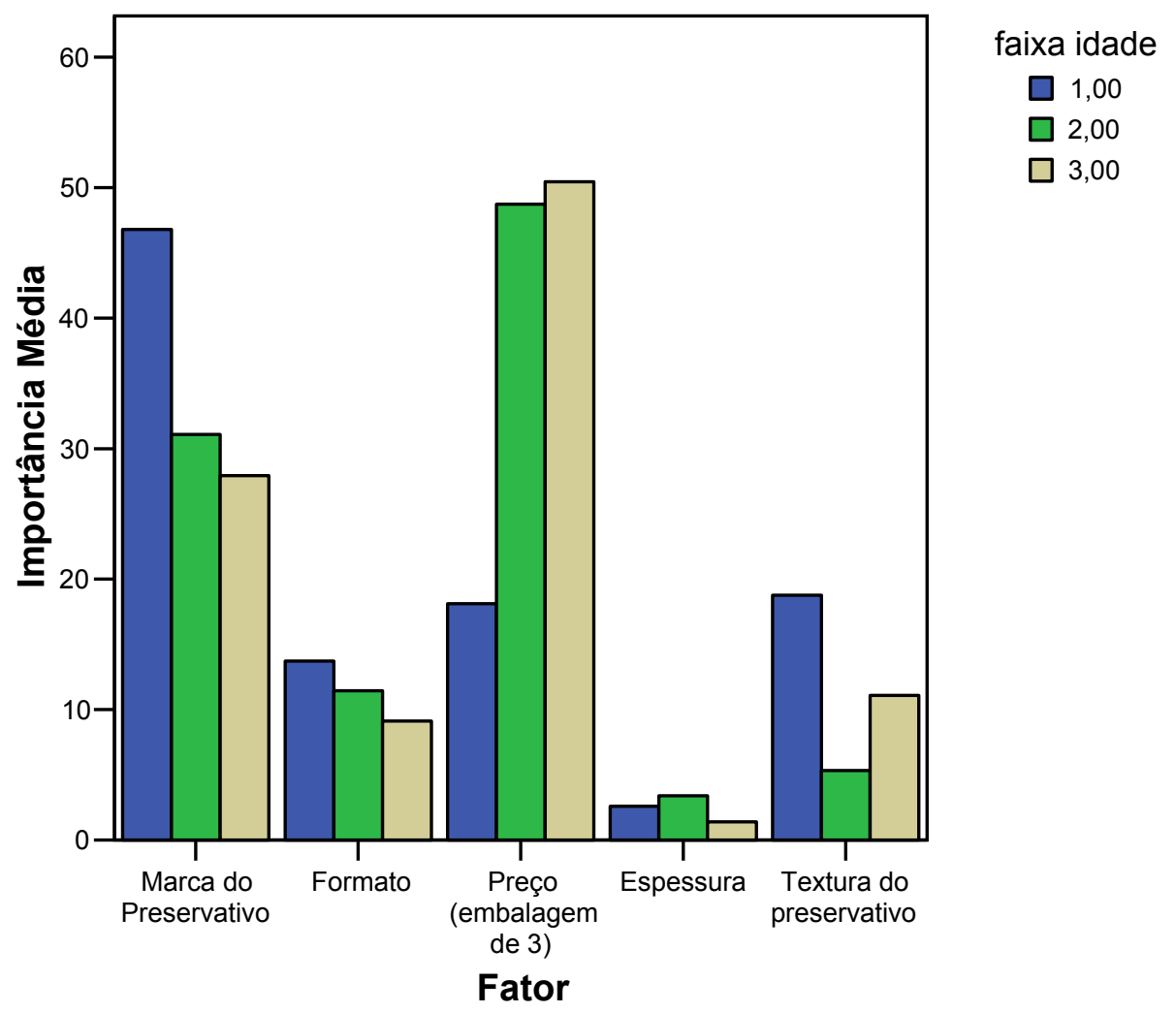


No que diz respeito às utilidades dos níveis dos fatores, os resultados sugerem as seguintes considerações:

a-) Para o atributo marca, os respondentes de todas as faixas de idade atribuem maior importância aos preservativos Jontex, com destacada preferência pelos mais jovens. A marca Olla é preferida distintamente pelos entrevistados da faixa de idade intermediária, comparado com a irrelevância com que é considerada pelos de outras faixas. Esses aspectos estão ilustrados no gráfico 51.

Gráfico 51 - Utilidades dos níveis do atributo marca, por faixa de idade

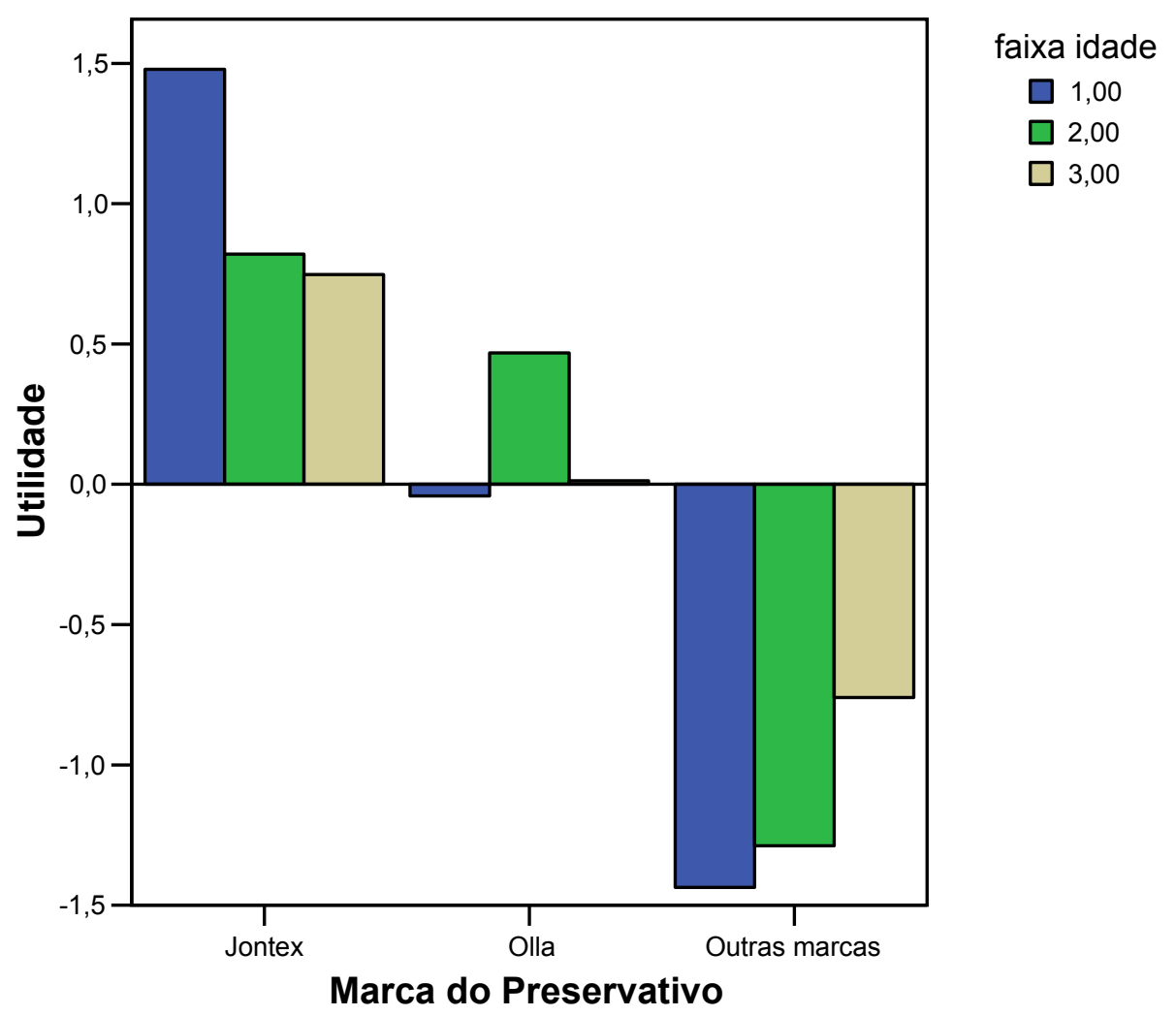


b-) Para o atributo preço, é interessante observar que os respondentes das faixas de idade intermediária (28 a 34 anos) e mais alta (35 a 53) dão maior importância para o preço mais baixo (R\$ 1,05) do que os jovens (18 a 27 anos). Estes, por sua vez, preferem o preço de $\mathrm{R} \$ 2,10$. Todas as faixas etárias rejeitam o preço mais alto de $\mathrm{R} \$ 3,20$, como pode ser constatado no gráfico 52.

Gráfico 52 - Utilidades dos níveis do atributo preço, por faixa de idade

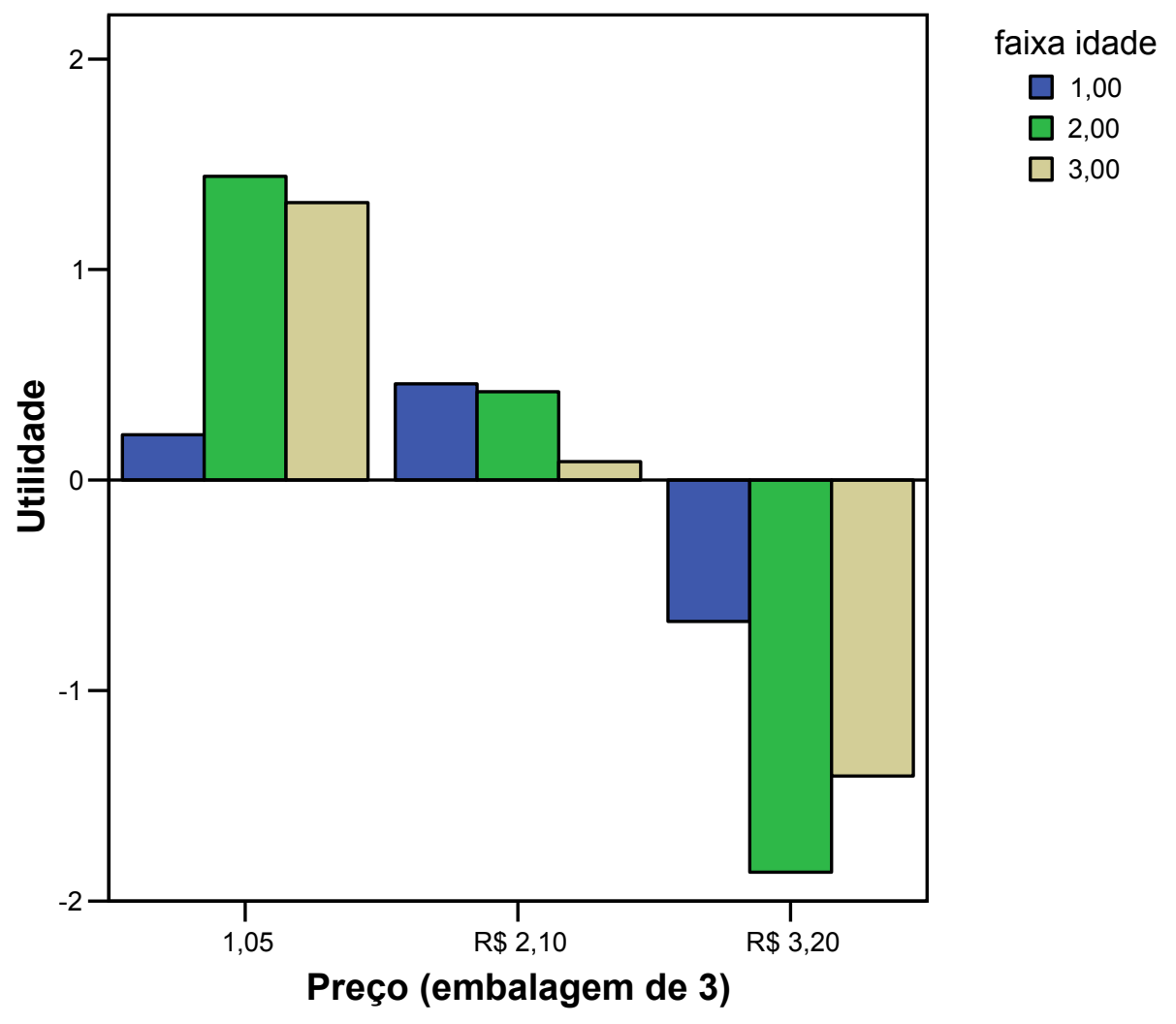


c-) No tocante ao formato, conforme ilustrado no gráfico 53, os respondentes de todas as faixas etárias dão maior importância ao formato anatômico, acompanhando a avaliação média.

Gráfico 53 - Utilidades dos níveis do atributo formato, por faixa de idade

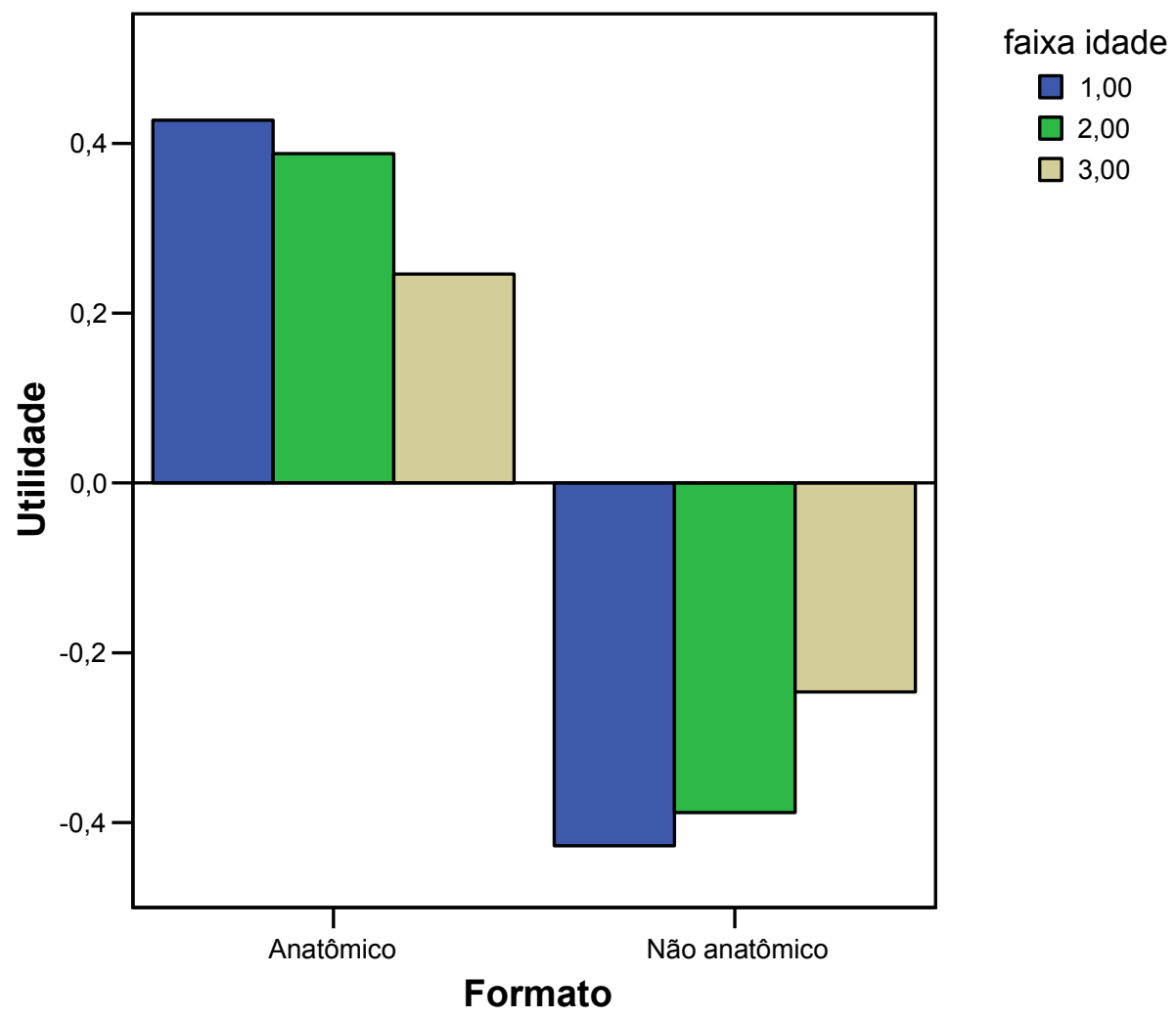


d-) Quando o atributo em análise é a espessura, conforme pode ser visualizado no gráfico 54, é interessante notar a forte rejeição que o preservativo mais fino sofre pelos respondentes das faixas de 18 a 34 anos, em contraposição aos da faixa de 35 a 53 anos, que preferem o fino.

Gráfico 54 - Utilidades dos níveis do atributo espessura, por faixa de idade

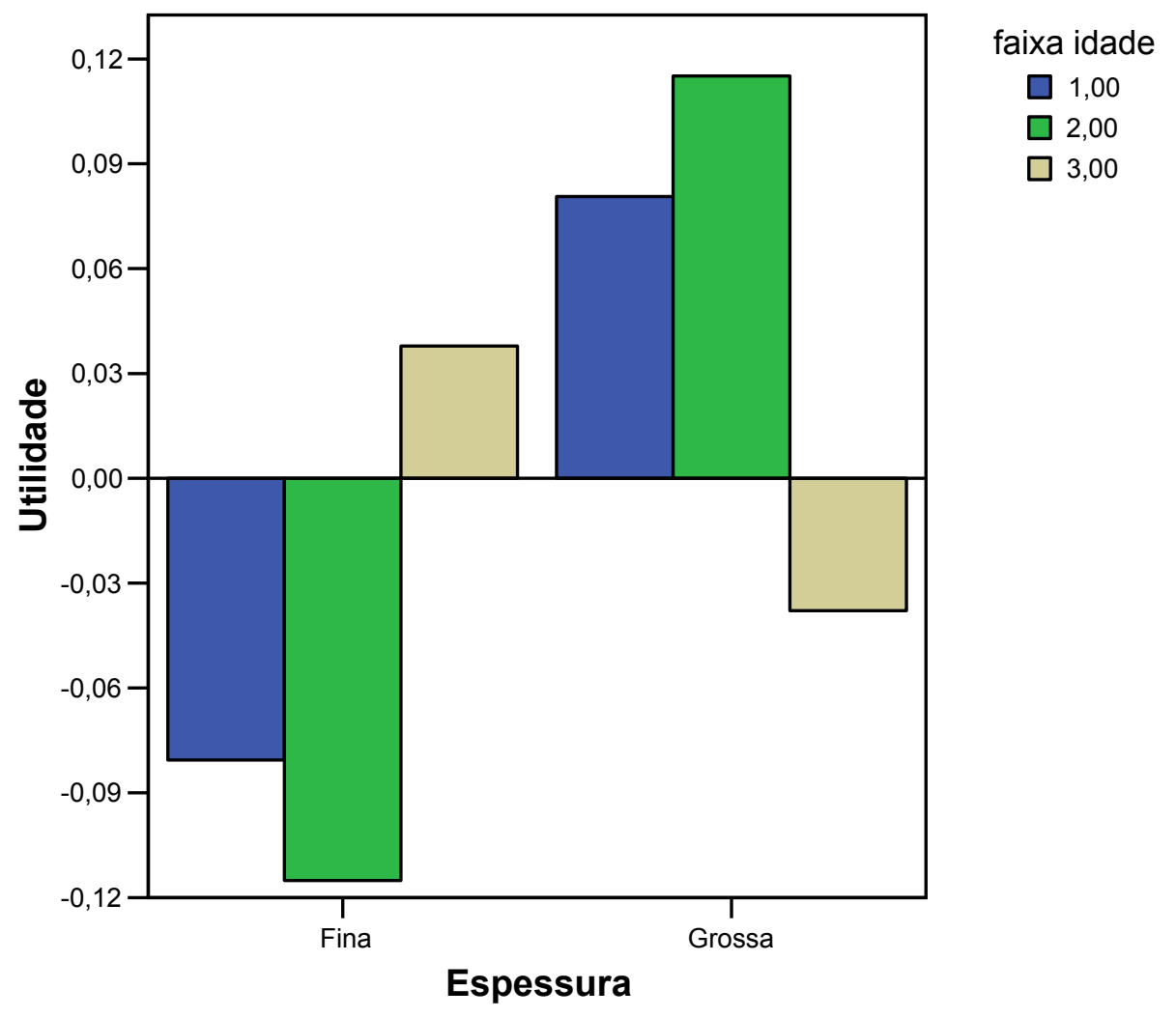


e-) No tocante à textura, os respondentes de todas as faixas etárias rejeitam o preservativo não liso, em especial os mais novos, conforme se observa no gráfico 55.

Gráfico 55 - Utilidades dos níveis do atributo textura, por faixa de idade

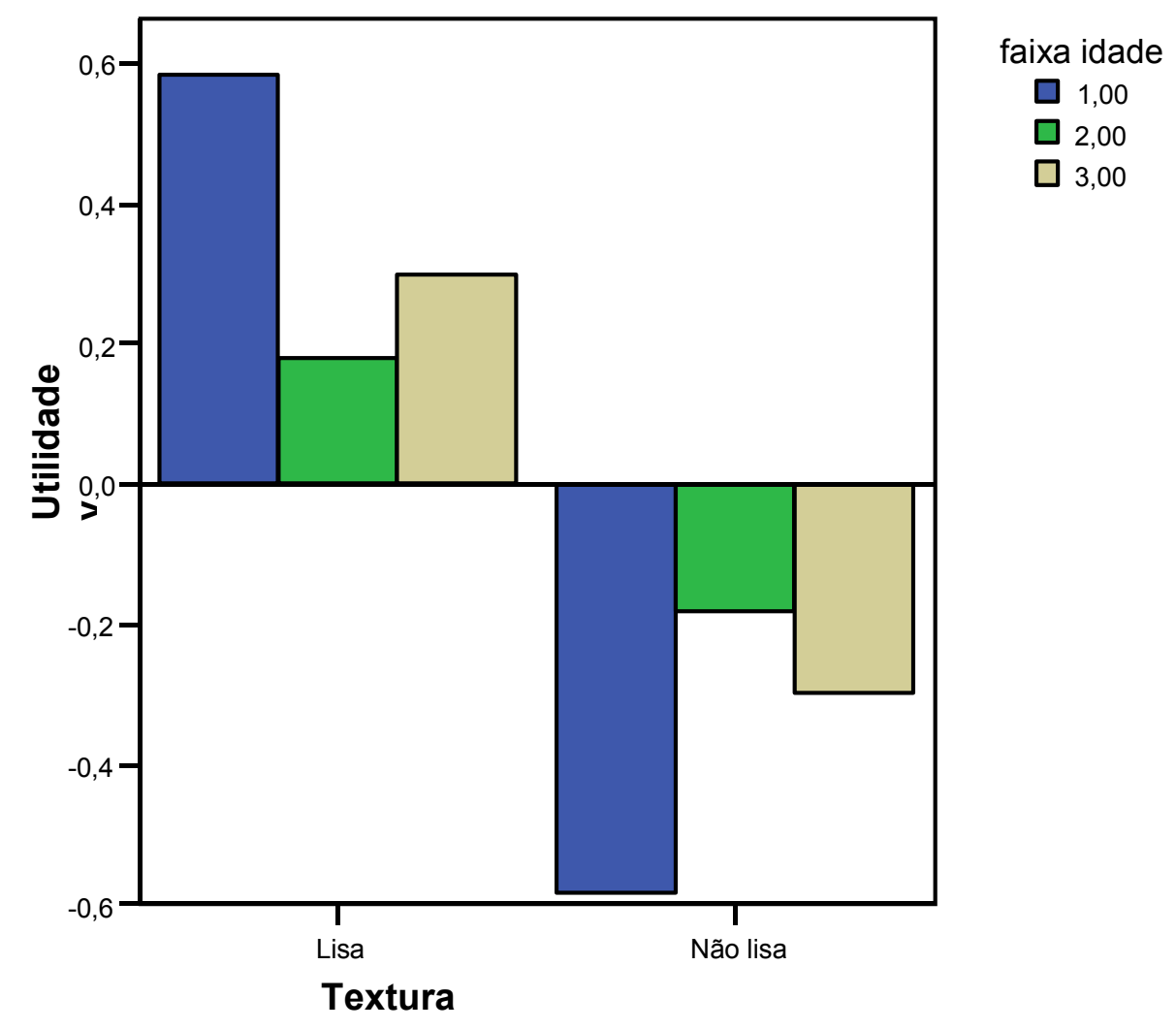




\section{ANÁLISES COMPLEMENTARES}

Como pôde ser acompanhado na Parte IV deste estudo - Metodologia da Pesquisa de Campo - o questionário para coleta de dados incluiu perguntas sobre outras variáveis, permitindo, assim, o enriquecimento da análise geral.

Uma das variáveis exploradas foi o conhecimento dos métodos contraceptivos pelos indivíduos de baixa renda. Mediante uma lista previamente preparada, contendo 7 técnicas de prevenção à gravidez, os entrevistados apontaram sobre quais já tinham ouvido falar a respeito, além do preservativo. As respostas foram múltiplas, isto é, o entrevistado poderia apontar para mais de um método. Os resultados mostram o preservativo (camisinha), a pílula anticoncepcional, a tabelinha e o DIU como os mais conhecidos, conforme se verifica no quadro 9.

Quadro 9 - Conhecimento dos métodos contraceptivos (respostas múltiplas)

\begin{tabular}{|l|c|c|}
\cline { 2 - 3 } \multicolumn{1}{c|}{} & NÚMERO DE RESPOSTAS & $\begin{array}{c}\text { \% dos respondentes } \\
\text { que conhecem o método }\end{array}$ \\
\hline CAMISINHA & 102 & 100,0 \\
DIU & 63 & 61,8 \\
PÍLULA & 79 & 77,5 \\
ESPERMICIDA & 18 & 17,6 \\
TABELINHA & 75 & 73,5 \\
COITO INTERROMPIDO & 28 & 27,5 \\
IMPLANTE SUBCUTÂNEO & 4 & 3,9 \\
NENHUM MÉTODO & 0 & 0,0 \\
\hline
\end{tabular}

As respostas também permitem uma visão do conhecimento dos métodos contraceptivos pela classe econômica do respondente. Novamente se salienta que a proporção de entrevistados de cada classe não é corresponde à da população, mas os resultados podem ser indícios para uma /pesquisa (rima com população) mais profunda. Observando-se os quadros 10, 11 e 12, o que se percebe é um decréscimo considerável no conhecimento dos métodos DIU e tabelinha, à medida que se reduz a classe do entrevistado. Assim, no caso do DIU, o percentual de respondentes que conhecem a técnica vai de $73,8 \%$ na classe $C$ para $44,8 \%$ na 
classe D e para $25,0 \%$ na E. Por sua vez, no caso da tabelinha, os percentuais são de $80,0 \%$, $69,0 \%$ e 37,5\%, respectivamente para os respondentes das classes C, D e E. A técnica do implante subcutâneo também chama atenção, uma vez que só é conhecida por uma pequena parte dos entrevistados da classe C.

Quadro 10 - Conhecimento dos métodos contraceptivos (respostas múltiplas dos entrevistados da classe C)

\begin{tabular}{|l|c|c|}
\cline { 2 - 3 } \multicolumn{1}{c|}{} & NÚMERO DE RESPOSTAS & $\begin{array}{c}\text { \% dos respondentes } \\
\text { que conhecem o método }\end{array}$ \\
\hline CAMISINHA & 65 & 100,0 \\
DIU & 48 & 73,8 \\
PÍLULA & 58 & 89,2 \\
ESPERMICIDA & 12 & 18,5 \\
TABELINHA & 52 & 80,0 \\
COITO INTERROMPIDO & 24 & 36,9 \\
IMPLANTE SUBCUTÂNEO & 4 & 6,2 \\
NENHUM MÉTODO & 0 & 0,0 \\
\hline TOTAL DE RESPONDENTES & 65 & 100,0 \\
DA CLASSE C & & \\
\hline
\end{tabular}

Quadro 11 - Conhecimento dos métodos contraceptivos (respostas múltiplas dos entrevistados da classe D)

\begin{tabular}{|l|c|c|}
\cline { 2 - 3 } \multicolumn{1}{l|}{} & NÚMERO DE RESPOSTAS & $\begin{array}{c}\text { \% dos respondentes } \\
\text { que conhecem o método }\end{array}$ \\
\hline CAMISINHA & 29 & 100,0 \\
DIU & 13 & 44,8 \\
PÍLULA & 18 & 62,1 \\
ESPERMICIDA & 5 & 17,2 \\
TABELINHA & 20 & 69,0 \\
COITO INTERROMPIDO & 3 & 10,3 \\
IMPLANTE SUBCUTÂNEO & 0 & 0,0 \\
NENHUM MÉTODO & 0 & 0,0 \\
\hline TOTAL DE RESPONDENTES & 29 & 100,0 \\
DA CLASSE D & & \\
\hline
\end{tabular}


Quadro 12 - Conhecimento dos métodos contraceptivos (respostas múltiplas dos entrevistados da classe E)

\begin{tabular}{|l|c|c|}
\cline { 2 - 3 } \multicolumn{1}{l|}{} & NÚMERO DE RESPOSTAS & $\begin{array}{c}\text { \% dos respondentes } \\
\text { que conhecem o método }\end{array}$ \\
\hline CAMISINHA & 8 & 100,0 \\
DIU & 2 & 25,0 \\
PÍLULA & 3 & 37,5 \\
ESPERMICIDA & 1 & 12,5 \\
TABELINHA & 3 & 37,5 \\
COITO INTERROMPIDO & 1 & 12,5 \\
IMPLANTE SUBCUTÂNEO & 0 & 0,0 \\
NENHUM MÉTODO & 0 & 0,0 \\
\hline TOTAL DE RESPONDENTES & 8 & 100,0 \\
DA CLASSE E & & \\
\hline
\end{tabular}

Outra variável que permitiu uma análise estatística foi a freqüência de compra do preservativo. Os entrevistados tiveram seis opções de reposta, abrangendo os seguintes períodos: toda semana, a cada 15 dias, uma vez por mês, a cada dois meses, a cada três meses e mais de três meses. Os que se encaixaram na opção 'mais de três meses' foram excluídos, pois, não foram considerados usuários freqüentes; portanto, não fizeram parte da pesquisa. Os resultados mostram no período de até 15 dias, pelo menos $65 \%$ dos respondentes fazem uma compra de preservativo, sendo pequenos os percentuais daqueles que compram a cada dois meses e a cada três meses $(6,9 \%$ e $2,0 \%$, respectivamente). Esses dados estão expostos no quadro 13, e visualizados no gráfico 56, obtido do processamento estatístico do SPSS.

Quadro 13 - Distribuição da freqüência de compra de preservativos

\begin{tabular}{|c|c|c|c|c|c|}
\hline \multicolumn{6}{|c|}{ Freqüência de compra } \\
\hline & & Frequency & Percent & Valid Percent & $\begin{array}{c}\text { Cumulative } \\
\text { Percent }\end{array}$ \\
\hline \multirow[t]{6}{*}{ Valid } & Toda semana & 33 & 32,4 & 32,4 & 32,4 \\
\hline & A cada 15 dias & 34 & 33,3 & 33,3 & 65,7 \\
\hline & Uma vez por mês & 26 & 25,5 & 25,5 & 91,2 \\
\hline & A cada 2 meses & 7 & 6,9 & 6,9 & 98,0 \\
\hline & A cada 3 meses & 2 & 2,0 & 2,0 & 100,0 \\
\hline & TOTAL & 102 & 100,0 & 100,0 & \\
\hline
\end{tabular}


Gráfico 56 - Distribuição da freqüência de compra de preservativos

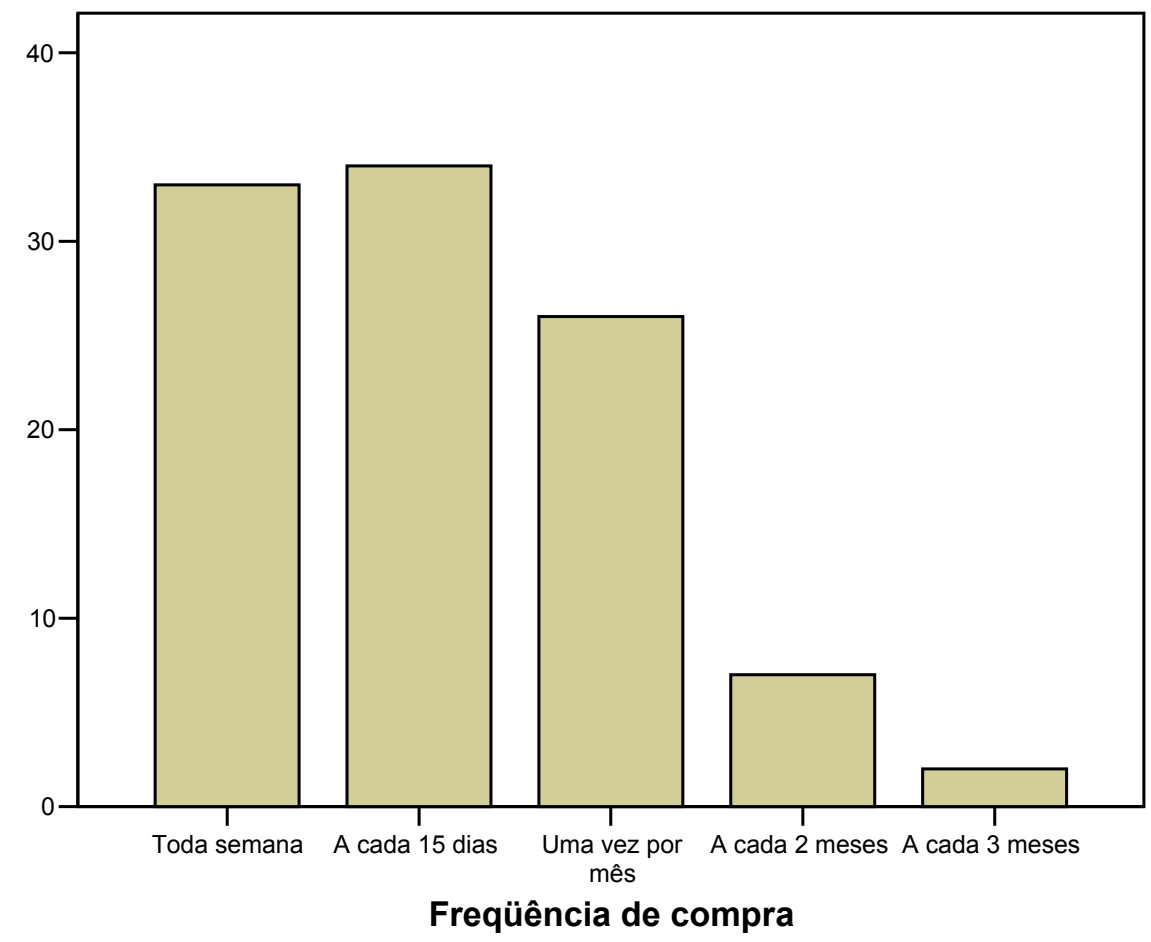

Quanto ao número de unidades compradas por vez, os valores resultantes do processamento estatístico do SPSS apontaram para uma média de 5,95, moda de 3 e mediana de 5, como pode ser confirmado no quadro 14. O número mínimo apontado foi de 1 e o máximo de 18. O quadro 15 mostra a distribuição de freqüências dessa variável, que também está ilustrada no gráfico 57.

Quadro 14 - Resultados estatísticos para a variável unidades por compra

\begin{tabular}{|c|c|c|}
\hline \multicolumn{3}{|c|}{ Statistics: Unidade por compra } \\
\hline \multirow[t]{2}{*}{$N$} & & 102 \\
\hline & & 0 \\
\hline Mean & & 5,95098 \\
\hline Median & & 5,00000 \\
\hline Mode & & 3,000 \\
\hline Std. Deviati & & 4,243521 \\
\hline Mininum & & 1,000 \\
\hline Maximum & & 18,000 \\
\hline \multirow[t]{3}{*}{ Percentiles } & 25 & 3,00000 \\
\hline & 50 & 5,00000 \\
\hline & 75 & 7,00000 \\
\hline
\end{tabular}


Quadro 15 - Distribuição de freqüências da variável unidades por compra

\begin{tabular}{|c|c|c|c|c|c|}
\hline \multicolumn{6}{|c|}{ Unidades por compra } \\
\hline & & Frequency & Percent & Valid Percent & $\begin{array}{c}\text { Cumulative } \\
\text { Percent }\end{array}$ \\
\hline \multirow[t]{14}{*}{ Valid } & 1,000 & 4 & 3,9 & 3,9 & 3,9 \\
\hline & 2,000 & 3 & 2,9 & 2,9 & 6,9 \\
\hline & 3,000 & 40 & 39,2 & 39,2 & 46,1 \\
\hline & 4,000 & 1 & 1,0 & 1,0 & 47,1 \\
\hline & 5,000 & 8 & 7,8 & 7,8 & 54,9 \\
\hline & 6,000 & 20 & 19,6 & 19,6 & 74,5 \\
\hline & 7,000 & 2 & 2,0 & 2,0 & 76,5 \\
\hline & 8,000 & 1 & 1,0 & 1,0 & 77,5 \\
\hline & 9,000 & 5 & 4,9 & 4,9 & 82,4 \\
\hline & 10,000 & 6 & 5,9 & 5,9 & 88,2 \\
\hline & 12,000 & 3 & 2,9 & 2,9 & 91,2 \\
\hline & 15,000 & 4 & 3,9 & 3,9 & 95,1 \\
\hline & 18,000 & 5 & 4,9 & 4,9 & 100,0 \\
\hline & TOTAL & 102 & 100,0 & 100,0 & \\
\hline
\end{tabular}

Gráfico 57 - Distribuição de freqüências da variável unidades por compra

\section{Unidades por compra}

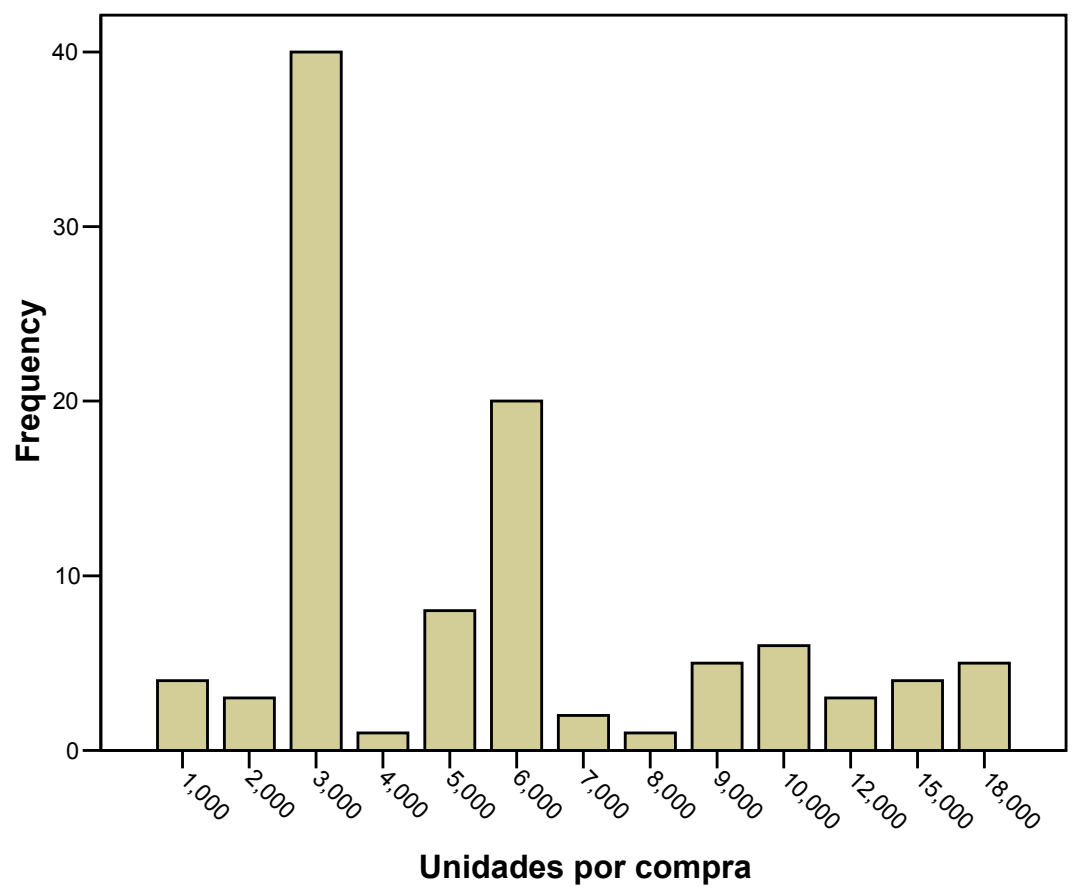


Uma vez apresentados os resultados da pesquisa de campo, o próximo passo foi resgatar as informações da pesquisa MS/IBOPE 2003 e associá-los para tornar a análise mais consistente. A próxima seção trata desse assunto. 


\section{PARTE VI \\ CONSIDERAÇÕES FINAIS}

\section{PRINCIPAIS RESULTADOS DA PESQUISA DE CAMPO E ASSOCIAÇÕES COM OUTRAS INFORMAÇÕES DE PESQUISA}

Os resultados obtidos pela pesquisa de campo trazem importantes subsídios para os objetivos deste trabalho. Parecem ser ainda mais enriquecedores, se avaliados também à luz da pesquisa MS/IBOPE 2003, cujos extratos foram mostrados na Parte III - seção 10.

Naquela pesquisa, observando-se o gráfico 19, ficou constatado que, independentemente do critério de segmentação do público, seja por classe econômica, idade, cor, sexo, região de residência, grau de instrução ou indicador de risco, o atributo considerado de maior importância foi marca, com larga vantagem sobre conforto, lubrificação, preço e textura, respectivamente o $2^{\circ}, 3^{\circ}, 4^{\circ}$ e $5^{\circ}$ atributos em importância. Embalagem, cheiro, tamanho e cor / sabor, parte de um grupo de atributos com baixos índices de preferência, vieram em seguida.

Sob a ótica das classes econômicas, observando-se o gráfico 24 , a referida pesquisa mostrou que, depois da marca, o atributo mais importante para os indivíduos de baixa renda foi o conforto, seguido do preço e da textura, estando esses dois, quase que no mesmo nível. Os demais atributos apresentaram baixo nível de importância.

Por sua vez, os resultados apresentados pela pesquisa de campo deste trabalho reforçam que marca é um atributo de grande importância para o indivíduo de baixa renda, mas não isolada, sendo até ligeiramente superada pelo fator preço. Esse aspecto dá indícios de que preços não adequados podem ser uma barreira para a aquisição do preservativo e devem ser a preocupação dos profissionais de marketing que tratam do posicionamento dele no mercado para o consumidor das classes populares. $\mathrm{O}$ uso do produto em bases regulares e seu peso no orçamento do consumidor, principalmente o das classes D e E, conforme observado na pesquisa MS/IBOPE 2003 e ilustrado no gráfico 31 da seção 10 deste estudo, reforçam essa idéia.

Formato, que se traduz em conforto, e textura, aparecem com níveis de importância mais baixos nos resultados da pesquisa de campo; no entanto, os índices registrados não são 
desprezíveis e devem merecer atenção por parte das ações de marketing. A espessura, por outro lado, não teve a mesma preferência, sendo avaliada como de baixa importância relativa.

Recorrendo novamente à pesquisa MS/IBOPE 2003, agora sob o enfoque da faixa etária da população sexualmente ativa, observou-se que os mais jovens atribuem maior importância à marca do que os de outras faixas. Em relação ao conforto, quanto mais velho o indivíduo, mais importante se torna esse fator. O preço é particularmente valorizado pelos indivíduos da faixa de 40 a 49 anos e a textura, pelos maiores de 50 anos.

Na pesquisa de campo deste estudo, os resultados por faixa etária mostraram a mesma tendência de os mais jovens avaliarem marca como o atributo mais importante e daqueles de faixas etárias mais altas valorizarem o fator preço.

Os resultados sugerem, portanto, que os profissionais de marketing das empresas de higiene e saúde, responsáveis pelo gerenciamento do produto preservativo, que desejam expandir seus negócios para mercados como os da população de baixa renda, precisam atentar prioritariamente aos dois fatores apontados como os mais significativos: marca e preço. No entanto, os atributos formato e textura parecem despontar como elementos úteis para se buscar diferenciação na disputa pelo mercado. 


\section{CONSIDERAÇÕES FINAIS}

O contexto em que se insere este estudo mostra a gravidade da situação da Aids no Brasil, com números de incidências e óbitos ainda assustadores. Ao longo da história da doença no país, a epidemia ganhou contornos específicos: deixou de perseguir apenas os indivíduos dos chamados grupos de risco (homossexuais masculinos e usuários de drogas injetáveis) e passou a atingir também heterossexuais de ambos os sexos. Nos últimos anos, os registros de avanço da doença mostram mulheres, jovens, usuários de drogas injetáveis, profissionais do sexo e população de baixa renda como os grupos mais afetados.

As classes populares ganharam ênfase neste estudo não só por essa razão. Estudos sobre taxas de fecundidade têm mostrado um aumento considerável do número de filhos entre mulheres dessas classes, o que pode levar a sérias implicações socioeconômicas, à medida que favorece o empobrecimento da sociedade.

Nesse cenário, os métodos contraceptivos assumem importância vital e em particular, o preservativo, por também desempenhar papel de prevenção contra DSTs e Aids. A exposição da história do produto e das suas características - desde a forma de fabricação até os atributos explorados na comercialização-, os concorrentes que disputam o mercado, a identificação de barreiras e preconceitos que ainda impedem o uso indiscriminado do preservativo - foram contemplados e deixaram espaço para reflexão sobre inúmeras oportunidades a serem exploradas por ações de marketing.

A investigação do perfil específico das classes populares, do seu estilo de vida e de consumo, a maneira como investem as sobras orçamentárias e escolhem as marcas, da linguagem de comunicação que entendem, de como escolhem os lugares para comprar e de como todos esses aspectos interferem na forma como fazem suas escolhas foram as linhas mestras para se buscar os objetivos do estudo. Ao mesmo tempo, permitiram destacar como o consumidor de baixa renda pode representar um significativo potencial de consumo, se compreendido adequadamente e focado como público-alvo da ação empresarial.

Para embasar esses aspectos, previamente foi apresentada a teoria do comportamento do consumidor, destacando os processos para tomada de decisão. Foram salientadas, nesse contexto, que algumas características do comprador, como culturais, sociais, pessoais e psicológicas funcionam como influenciadoras daqueles processos. 
Mais especificamente, abordaram-se facetas do comportamento de compra e uso do preservativo, resgatando estudos que o colocam sob controle do homem, estando a sua utilização associada ao gênero, além da cultura sexual e dos papéis sociais atribuídos a homens e mulheres. O consumo do produto é motivado por desejos afetivos e, por isso, considerado como "consumo hedônico", envolvendo elementos ligados ao multissensorial e às emoções. Após o advento da Aids, tais emoções passaram a ser caracterizadas pela ansiedade diante da doença, favorecendo atitudes positivas em relação aos anúncios de preservativos, por parte dos mais ansiosos, e diante das marcas, por parte dos grupos de risco.

No contexto brasileiro, salientou-se que a resistência ao uso do preservativo ainda está presente, com a significativa redução da população sexualmente ativa que utiliza o produto consistentemente. Os indivíduos com relação estável e exclusiva foram os que mais contribuíram para o feito, dando indícios de que as razões para o não uso estão ligadas à confiança depositada no parceiro. Comportamento semelhante se verificou com indivíduos de menor escolaridade (com até a $4^{\text {a }}$ série), ao contrário dos mais jovens (de 14 a 25 anos), que estão entre os que usam o preservativo mais consistentemente e entre os que mais o usam na primeira relação sexual.

Para alicerçar a discussão sobre o produto, foram abordados dois conceitos teóricos relevantes: o primeiro sobre marca e seus ativos, mostrando sua importância para o sucesso das estratégias de posicionamento de mercado e fidelização de clientes; o segundo, sobre atributos de produto, destacando características como embalagem, rotulagem, preço e sua influência na qualidade percebida do produto.

Resgatando o extrato teórico de Lee e Lou (1995/1996) retratado na seção 7.3, consumidores que têm maior familiaridade e envolvimento com a categoria de produto, confiam mais fortemente em atributos extrínsecos como nome da marca e preço, enquanto os que se encontram mais envolvidos na situação de avaliação do produto valorizam mais os atributos intrínsecos (ligados à parte física do produto). Os resultados deste estudo, conforme apresentado na seção 24, parecem reforçar a idéia de que o consumidor de baixa renda, no processo de compra de preservativos, encontra-se na situação de intenso envolvimento com a categoria e não com a situação de avaliação do produto, pois atribui forte importância a marca e preço. 


\subsection{LIMITAÇÕES DA PESQUISA DE CAMPO E RECOMENDAÇÕES PARA PRÓXIMAS PESQUISAS}

Alguns fatores presentes no âmbito da pesquisa de campo acabam por limitá-la e merecem ser reportados no trabalho.

O primeiro está relacionado ao foco dirigido apenas aos indivíduos do sexo masculino. Como pode ser observado no estudo, em função da escalada da Aids e dos índices de fecundidade, as mulheres das classes populares tornam-se cada vez mais o alvo de políticas de prevenção da doença. Dessa forma, é conveniente que, em futuro próximo, também sejam investigados a importância e os pesos conferidos a cada atributo do produto por esse segmento de público.

Outra limitação presente está atrelada ao caráter exploratório da pesquisa de campo, que, por sua própria natureza, não permite generalização dos resultados para toda a classe popular do país, nem mesmo para cada uma das classes componentes (C, D e E). Para uma investigação mais profunda, seria necessário aumentar a abrangência geográfica e utilizar uma amostra com efetiva representatividade estatística.

A Conjoint Analysis, por si só, apresenta uma certa complexidade no processo de aplicação, exigindo, do entrevistador, habilidade para expor o procedimento de coleta de dados e, do entrevistado, capacidade de análise e predisposição para participar da pesquisa. Sendo o respondente um indivíduo da classe popular, com grau de instrução geralmente limitado, o processo torna-se mais lento e suscetível a erros, exigindo cuidados adicionais.

Por último, o tema apresenta uma abordagem bastante específica, limitada a um produto e a um segmento de classe econômica. Dada a importância do contexto no qual se desenrola o estudo, expandir a visão para outros produtos, como o preservativo feminino, bem como para os demais estratos da população, poderia trazer resultados de maior amplitude para se enfrentar os problemas de saúde pública que assolam o país e o mundo.

Este estudo, portanto, não teve a pretensão de esgotar as discussões relacionadas ao tema. $\mathrm{O}$ intuito foi dar mais um passo na compreensão do comportamento de compra, focado no consumidor de baixa renda, na tentativa de abrir horizontes para que novas pesquisas venham a acrescentar conhecimento ao assunto. 


\section{BIBLIOGRAFIA}

AAKER, D. A. Marcas: Brand Equity - Gerenciando o Valor da Marca. São Paulo: Negócio, 1998.

AAKER, D. A.; KUMAR, V.; DAY, G. S. Pesquisa de Marketing. São Paulo: Atlas, 2001.

ALMAP/BBDO. Pesquisa O poder da classe D (1996). Disponível em: <http://www.nbz. com.br/artigos/marketing/poder.html $>$. Acesso em: 21 jul.2003.

ASSOCIAÇÃO BRASILEIRA DE NORMAS TÉCNICAS (ABNT). Referências Bibliográficas. NBR 6023/2000. Rio de Janeiro: 2000.

ASSOCIAÇÃO NACIONAL DAS EMPRESAS DE PESQUISA DE MERCADO (ANEP). Disponível em $<$ http://www.anep.org.br>. Acesso em 21 jul. 2003.

ARTES, R. Análise de Preferência "Conjoint Analysis”. 1991. Dissertação (Mestrado em Estatística) - Instituto de Matemática e Estatística da Universidade de São Paulo, Universidade de São Paulo, São Paulo, 1991.

BLAÜSIEGEL INDÚSTRIA E COMÉRCIO LTDA. Disponível em: $<$ http://www.preserv.com.br>. Acesso em: 11 nov. 2003.

BLOWTEX. Disponível em: <http://www.blowtex.com.br>. Acesso em: 11 nov. 2003.

BOSTON CONSULTING GROUP. Mercados Pouco Explorados: Descobrindo a Classe C. São Paulo. 2002. Disponível em <http://www.bcg.com>. Acesso em: 20 set. 2002.

BRASIL. MINISTÉRIO DA SAÚDE. Secretaria de Políticas de Saúde. Coordenação Nacional de DST/Aids. Aceitabilidade do condom feminino. Brasil. 1999. In: PROGRAMA NACIONAL DE DST E AIDS. Disponível em <http://www.aids.gov.br/final/prevencao/ feminin1.htm>. Acesso em: 30 mai. 2004.

- Acesso a preservativos distribuídos pela rede pública de saúde e padrão de compra de preservativo (MS/IBOPE 2003). In: PROGRAMA NACIONAL DE DST E AIDS. Disponível em: <http://www.aids.gov.br/final/biblioteca/ibope_2003/preservativo1.doc $>$. Acesso em: 18 nov. 2003.

Boletim Epidemiológico Aids. In: PROGRAMA NACIONAL DE DST E AIDS. Disponível em: <http://www.aids.gov.br/final/biblioteca/boletim_dezembro_2003/bol_de zembro_2003.pdf $>$ Acesso em: 04 jul. 2004.

Campanhas de massa e ações de impacto. In: PROGRAMA NACIONAL DE DST E AIDS. Disponível em: $<$ http://www.aids.gov.br/final/prevencao/campanha.htm>. Acesso em: 18 nov. 2003.

Comportamento da população brasileira sexualmente ativa (MS/IBOPE 2003). In: PROGRAMA NACIONAL DE DST E AIDS. Disponível em: <http://aids.gov.br/final/biblio 
teca/ibope_2003/briefing2.doc>. Acesso em: 18 nov. 2003.

Dados e pesquisas em DST e Aids. In: PROGRAMA NACIONAL DE DST E AIDS. Disponível em: <http://www.aids.gov.br/final/dados/aids.htm>. Acesso em: 04 jul.2004.

O perfil da Aids no Brasil e metas do governo para o controle da epidemia. In: PROGRAMA NACIONAL DE DST E AIDS. Disponível em: <http://www.aids.gov.br/final/ biblioteca/metas/metas.pdf $>$. Acesso em: 18 nov. 2003.

Pela camisinha não passa nada. Use e confie. In: PROGRAMA NACIONAL DE

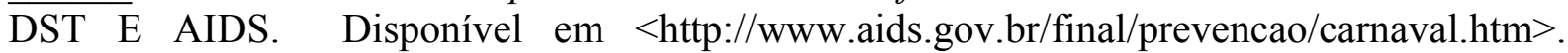
Acesso em: 18 nov. 2003.

Política Brasileira de AIDS. Principais resultados e avanços 1994 a 2002. Brasil. Disponível em: < http://www.aids.gov.br/final/biblioteca/política_94_02.pdf $>$. Acesso em: 18 nov. 2003.

. Saúde alerta Igreja sobre perigos da resistência ao uso de preservativos. In: PROGRAMA NACIONAL DE DST E AIDS. Disponível em: <http://www.aids.gov.br/ saude_alerta.htm>Acesso em: 30 mai. 2004.

. Unaids divulga números da aids em todo o mundo (Releases do PN-DST/AIDS, 06 jul. 2004). Disponível em: $<$ http://www.aids.gov.br/imprensa/Noticias.asp?NOTCod=58253>. Acesso em: 10 jul. 2004.

BRASIL. MINISTÉRIO DA SAÚDE/CEBRAP. Comportamento Sexual da População Brasileira e Percepções do HIV/AIDS. São Paulo. 2000. In: PROGRAMA NACIONAL DE DST E AIDS. Disponível em <http://www.aids.gov.br/final/biblioteca/avalia4/home.htm>. Acesso em: 11 out. 2003.

CERVO, A. L..; BERVIAN, P. A. Metodologia Cientifica. São Paulo: Prentice Hall, 2002.

CHURCHILL JR., G. A; PETER, J. P. Marketing: Criando Valor para os Clientes. São Paulo: Saraiva, 2003.

DATAFOLHA. Pesquisa Top of Mind. São Paulo. 2003. Disponível em: $<$ http://www1.folha. uol.com.br/folha/especial/2003/topofmind/fi0810200316.shtml>. Acesso em: 17 jul. 2004.

DATAPOPULAR In: SEMINÁRIO GVcev "Conhecendo o Consumidor de Baixa Renda". 17 jun. 2004. Disponível em: $<$ http://www.fgvsp.br/cev/index.cfm?page=007780> Acesso em: 09 jul. 2004.

HOLANDA, A. B. Dicionário Aurélio. Disponível em: $<$ http://www.uol2.com.br/aurelio $>$. Acesso em: 18 nov. 2003.

ELUF, L. N. Demografia e pobreza. O Estado de São Paulo, São Paulo, 30 jun. 2004. Disponível em: $<\mathrm{http}: / / \mathrm{www}$.aids.org.br/imprensa/Noticias.asp?NOTCod=58040>. Acesso em: 03 jul. 2004.

ENGEL, J. F.; BLACKWELL, R. D.; MINIARDI, P. W. Comportamento do Consumidor. Rio de Janeiro: LTC, 2000. 
GREEN, P. E.; SRINIVASAN, V. Conjoint analysis in consumer research: issues and outlook. Journal of Consumer Research, v.5, p. 103-123, sep.1978.

GUSTAFSSON, A.; EKDHAL, F.; BERGMAN, B. Conjoint Analysis: a useful tool in tech design process. Total Quality Management \& Business Excellence. v.10, n.3. p. 327-343.

GUTTMACHER, S.; LIEBERMAN, L.; WARD, D.; FREUDENBERG, N.; RADOSH, A.; JARLAIS, D. D. Condom Availability in New York City Public High Schools: Relationships to Condom Use and Sexual Behavior. American Journal of Public Health; v. 87, n. 9; p.142733. sep.1997.

HAIR JR, J.F.; ANDERSON, R. E.; TATHAM, R.L.; BLACK, W.C. Multivariate Data Analysis with readings. 4.ed. USA: Prentice Hall, 1995.

HAVLENA, W.W.J.; HOLBROOK, M. B. The Varieties of Consuption Experience: Comparing Two Typologies of Emotion in Consumer Behavior. Journal of Consumer Research. v.13 n.4, p.394-404. 1986.

HILL, R. P. An Exploration of the Relationship Between AIDS-Related Anxiety and the Evaluation of Condom Advertisements. Journal of Advertising. v.17 n.4, p.35-42. 1988.

HILL, R. P. The Growing Threat of AIDS: How Marketers Must Respond. Journal of Health Care Marketing. v.9, p.5-12. June 1989.

HILL, R. P.; STEPHENS, D.L. Using Condoms in the Age of AIDS: A Phenomenological Study with Marketing Implications. Journal of Health Care Marketing. v.10, n.1; p. 26-35. 1990.

HIRSCHMAN, E. C.; HOLBROOK, M. B. Hedonic Consumption: Emerging Concepts, Methods and Propositions. Journal of Marketing. v.46, p.92-101. summer 1982.

HOLBROOK, M. B \& HIRSCHMAN, E. C. The Experiential Aspects of Consumption: Consumer Fantasies, Feelings and Fun. Journal of Consumer Research. v.9 n.3, p.132-40. 1982.

INDICADORES DE DADOS BÁSICOS (IDB). Disponível em: <http://tabnet.datasus. gov.br>. Acesso em: 09 jul. 2004.

IBOPE SOLUTION. Mulheres da classe C - segmentação. In: REUNIÃO DE VENDAS UNIDADE DE ALTO CONSUMO. São Paulo: Abril, 2003.

INDÚSTRIA NACIONAL DE ARTEFATOS DE LÁTEX (INAL). Disponível em: $<$ http://www.olla.com.br>. Acesso em: 11 nov. 2003.

INSTITUTO BRASILEIRO DE GEOGRAFIA E ESTATÍSTICA (IBGE). Disponível em: $<$ http://www.ibge.gov.br>. Acesso em: 20 out. 2003.

INSTITUTO BRASILEIRO DE GEOGRAFIA E ESTATÍSTICA (2000). Censo Demográfico 2000. Disponível em: <http://www.ibge.gov.br/ >. Acesso em: 04 jul. 2004.

INSTITUTO BRASILEIRO DE GEOGRAFIA E ESTATÍSTICA (2002). Pesquisa Nacional por Amostra de Domicilios - PNAD. 2002. Disponível em: <http://www.ibge.gov.br/home 
/estatistica/populacao/trabalhoerendimento/pnad2002/brasilpnad2002.pdf $>$. Acesso em: 08 jun. 2004.

INSTITUTO BRASILEIRO DE GEOGRAFIA E ESTATÍSTICA (2003). Estatísticas do Século XX. Disponível em <http: \www.ibge.gov.br>. Acesso em: 18 nov. 2003.

INSTITUTO DE PESQUISAS ECONÔMICAS APLICADAS (IPEA). Disponível em: $<$ http://www.ipea.gov.br>. Acesso em: 05 jul. 2003.

JORNAL DA TARDE. Disponível em: <http://www.jt.com.br/editorias/2002/09/18/ eco008.html>. Acesso em: 23 jul. 2003.

JOHNSON\&JOHNSON. Disponível em $<$ http://www.jnjbrasil.com.br/jontex $>$. Acesso em: 11 nov. 2003.

JOHNSON\&JOHNSON. Disponível em: <http://www.jnjbrasil.com.br/jontex/historia.asp> . Acesso em: 11 nov.2003

KINNEAR, T. C.; TAYLOR, J. R. Marketing Research - An Applied Approach. New York: Mc Graw-Hill, 1996.

KOTLER, P. Administração de Marketing. São Paulo: Prentice Hall, 2000.

LAKATOS, E. M.; MARCONI, M. A. Metodologia Científica. São Paulo: Atlas, 1991.

LATIN PANEL. Painel de Consumidores da Classe C (2002). Disponível em: $<$ http://www.abrasnet.com.br/super>. Acesso em: 10 jun. 2004.

LEE, M. LOU, Y. Consumer reliance on Intrinsic and Extrunsic Cues in Product Evaluations: A Conjoint Approach. Journal of Applied Business Research. v.12, n. 1; p.21-28; Winter 1995/1996.

MATTAR, F. N. Pesquisa de Marketing 1. São Paulo: Atlas, 1997.

MATTAR, F. N. Pesquisa de Marketing 1. São Paulo: Atlas, 1999.

SALES, D. E. A. Os preservativos e a AIDS. In: Arquidiocese de São Sebastião do Rio de Janeiro. 2002. Disponível em: <http://www.arquidiocese.org.br/paginas/v15022002.htm>. Acesso em: 30 mai. 2004.

MOTA, M.P. Gênero e sexualidade: fragmentos de identidade masculina nos tempos da Aids. Cad. Saúde Pública, jan / mar. 1998, vol. 14. n.1, p.145-155. Disponível em: <http://www.sci elosp.org/scielo.php?script=sci_arttext\&pid=SO102-311X1998000100022\&lng=pt\&nrm= iso $>$. ISSN 0102-311X.

MOWEN, J.C.; MINOR, M. Consumer Behavior. New Jersey: Prentice-Hall, 1997.

OSSELAER, S.M.J.V.; ALBA, J.W. Consumer Learning and Brand Equity. Journal of Consumer Research; v.27, n.1; p.1-16. Jun 2000.

REVISTA VEJA. São Paulo, Abril, ano 37, n.23, 09 jun. 2004. 
SAAB, M. S. B. L. M. Valor Percebido pelo consumidor: um estudo de atributos da carne bovina. 1999. Dissertação (Mestrado em Administração) - Faculdade de Economia, Administração e Contabilidade da Universidade de São Paulo. São Paulo, Universidade de São Paulo, 1999.

SHETH, J. N.; MITTAL, B.; NEWMAN, B. I. Comportamento do Cliente - Indo além do comportamento do consumidor. São Paulo: Atlas, 2001.

SHIFFMAN, L.G.; KANUK. L.L. Consumer Behavior. New Jersey: Prentice-Hall, 1997.

SIQUEIRA, J. O. Mensuração da estrutura de preferência do consumidor: uma aplicação de conjoint analysis em marketing. 1997. Dissertação (Mestrado em Administração)- Faculdade de Economia, Administração e Contabilidade. São Paulo, Universidade de São Paulo,1997.

SOLOMON, M. R. Consumer Behavior. New York: Prentice Hall, 1998.

SPSS Training - Advanced Market Research. Chicago: SPSS, 2001.

SURI, R.; MONROE, K.B. The effects of time constraints on consumers' judgments of prices and products. Journal of Consumer Research.Gainesville. v. 30, n.1; p.92; Jun. 2003.

UNAIDS - Joint United Nations Programme on HIV/AIDS (PROGRAMA DAS NAÇÕES UNIDAS SOBRE HIV/AIDS). Disponível em: <http://www.unaids.org $>$. Acesso em: 6 jul. 2004.

WORLD HEALTH ORGANIZATION (WHO). Disponível em: < http://www.who.int/media centre/releases/2003/prunaids/en/print.html>. Acesso em: 25 nov. 2003.

WORLD HEALTH ORGANIZATION (WHO). Disponível em: $<$ http://www.who.int/healthservices-delivery/hiv_aids/Portuguese/Fact Sheet_PR_1.htm>. Acesso em: 11 jul. 2004.

ZAICHKOWSKY, J. L. Measuring the Involvement Construct. Journal of Consumer Research. v.12, p.341-352. December 1985. 


\section{APÊNDICES}

\section{APÊNDICE A - MODELO DO QUESTIONÁRIO}

\section{DADOS CADASTRAIS}

Endereço:

Profissão:

Fone Resl.: Celular: Fone Coml.:

\section{CLASSIFICACCÃO SÓCIO-ECONÔMICO}

2.1 Qual a sua posição no domicílio (na sua casa)?

\begin{tabular}{|r|l|}
\hline 1 & Chefe da família/cabeça da família \\
\hline 2 & Esposa/Marido \\
\hline 3 & Filho/Filha \\
\hline 4 & Agregado \\
\hline 5 & Outros \\
\hline
\end{tabular}

2.2 Escolaridade do/da chefe da família (seu pai ou mãe):

\begin{tabular}{|r|l|c|}
\hline 1 & Analfabeto/Primário Incompleto & 0 \\
\hline 2 & Primário Completo/Ginasial Incompleto & 1 \\
\hline 3 & Ginasial Completo/Colegial Incompleto & 2 \\
\hline 4 & Colegial Completo/Superior Incompleto & 3 \\
\hline 5 & Superior Completo & 5 \\
\hline
\end{tabular}

2.3 Caso você não seja o/a chefe da família, favor informar sua escolaridade:

\begin{tabular}{|r|l|}
\hline 1 & Analfabeto/Primário Incompleto \\
\hline 2 & Primário/Ginasial Incompleto \\
\hline 3 & Ginasial/Colegial Incompleto \\
\hline 4 & Colegial/Superior Incompleto \\
\hline 5 & Superior Completo \\
\hline
\end{tabular}


2.4 Dados de Classificação (circule o número correspondente à quantidade de produtos da primeira linha)

\begin{tabular}{|c|c|c|c|c|c|c|c|}
\hline VOCÊ TEM EM CASA ... & 1 & 2 & 3 & $\begin{array}{c}4 \\
\text { ou } \\
+ \\
\end{array}$ & \multicolumn{2}{|c|}{ ESCOLARIDADE } & $\begin{array}{c}\text { CHEFE } \\
\text { DA } \\
\text { FAMÍLIA }\end{array}$ \\
\hline TV em cores & 2 & 3 & 4 & 5 & \multicolumn{2}{|c|}{ Analfabeto / Primário Incompleto } & 0 \\
\hline Rádio & 1 & 2 & 3 & 4 & \multicolumn{2}{|c|}{ Primário Completo / Ginásio Incompleto } & 1 \\
\hline Banheiros & 2 & 3 & 4 & 4 & \multicolumn{2}{|c|}{ Ginásio Completo / Colegial Incompleto } & 2 \\
\hline Automóvel de passeio & 2 & 4 & 5 & 5 & \multicolumn{2}{|c|}{ Colegial Completo / Superior Incompleto } & 3 \\
\hline Empregada mensalista & 2 & 4 & 4 & 4 & \multicolumn{2}{|c|}{ Superior Completo } & 5 \\
\hline Aspirador de pó & 1 & 1 & 1 & 1 & \multirow{6}{*}{$\begin{array}{l}\text { TOTAL } \\
\text { DE } \\
\text { PONTOS }\end{array}$} & 30 a 34 pontos & A1 \\
\hline Máquina de lavar roupa & 1 & 1 & 1 & 1 & & 25 a 29 pontos & A2 \\
\hline Vídeo Cassete / DVD & 2 & 2 & 2 & 2 & & 21 a 24 pontos & B1 \\
\hline Geladeira & 2 & 2 & 2 & 2 & & 17 a 20 pontos & B2 \\
\hline \multirow{2}{*}{$\begin{array}{l}\text { Freezer (Independente ou parte } \\
\text { da geladeira) }\end{array}$} & \multirow[b]{2}{*}{1} & \multirow[b]{2}{*}{1} & \multirow[b]{2}{*}{1} & \multirow[b]{2}{*}{1} & & 11 a 16 pontos & C \\
\hline & & & & & & 06 a 10 pontos & $\mathbf{D}$ \\
\hline
\end{tabular}

2.5 Número de Pontos:

3. Em que faixa de renda mensal sua família se encontra:
( ) até $R \$ 240$
() de $R \$ 241$ a $R \$ 480$
( ) de $\mathrm{R} \$ 481$ a $\mathrm{R} \$ 960$
( ) de $\mathrm{R} \$ 961$ a $\mathrm{R} \$ 1440$
( ) de $\mathrm{R} \$ 1441$ a $\mathrm{R} \$ 1920$
() de $R \$ 1921$ a $R \$ 2400$
( ) mais de $\mathrm{R} \$ 2401$

4. Quais os métodos para evitar gravidez e Aids você conhece, mesmo que seja só de ouvir falar?

5. E destes que vou citar, quais conhece ao menos de ouvir falar?

6. E destes que conhece, qual já fez uso (você ou sua parceira) alguma vez?

7. E qual é o mais freqüentemente utilizado por você?

\begin{tabular}{|l|c|c|c|c|}
\hline \multicolumn{1}{|c|}{ TIPO } & Perg 4 & Perg 5 & Perg 6 & Perg 7 \\
\hline Camisinha / Preservativo / Condom & $\mathbf{1}$ & $\mathbf{1}$ & $\mathbf{1}$ & $\mathbf{1}$ \\
\hline DIU & $\mathbf{2}$ & $\mathbf{2}$ & $\mathbf{2}$ & ENCERRE \\
\hline Anticoncepcionais & $\mathbf{3}$ & $\mathbf{3}$ & $\mathbf{3}$ & ENCERRE \\
\hline Espermecida & $\mathbf{4}$ & $\mathbf{4}$ & $\mathbf{4}$ & ENCERRE \\
\hline Tabelinha & $\mathbf{5}$ & $\mathbf{5}$ & $\mathbf{5}$ & ENCERRE \\
\hline Coito interrompido & $\mathbf{6}$ & $\mathbf{6}$ & $\mathbf{6}$ & ENCERRE \\
\hline Subcutâneo & $\mathbf{7}$ & $\mathbf{7}$ & $\mathbf{7}$ & ENCERRE \\
\hline NENHUM & $\mathbf{8}$ & $\mathbf{8}$ & ENCERRE \\
\hline
\end{tabular}

8. Em média, com que freqüência você. costuma comprar camisinhas pessoalmente?
( ) toda semana
( ) a cada 15 dias
() a cada 2 meses
( ) uma vez por mês
() a cada 3 meses
( ) mais de 3 meses

9. Em média, quantas unidades costuma adquirir em cada compra? 
APÊNDICE B - DESENHOS ESQUEMÁTICOS UTILIZADOS NA COLETA DE DADOS

a-) Camisinha com formato não anatômico e textura lisa.

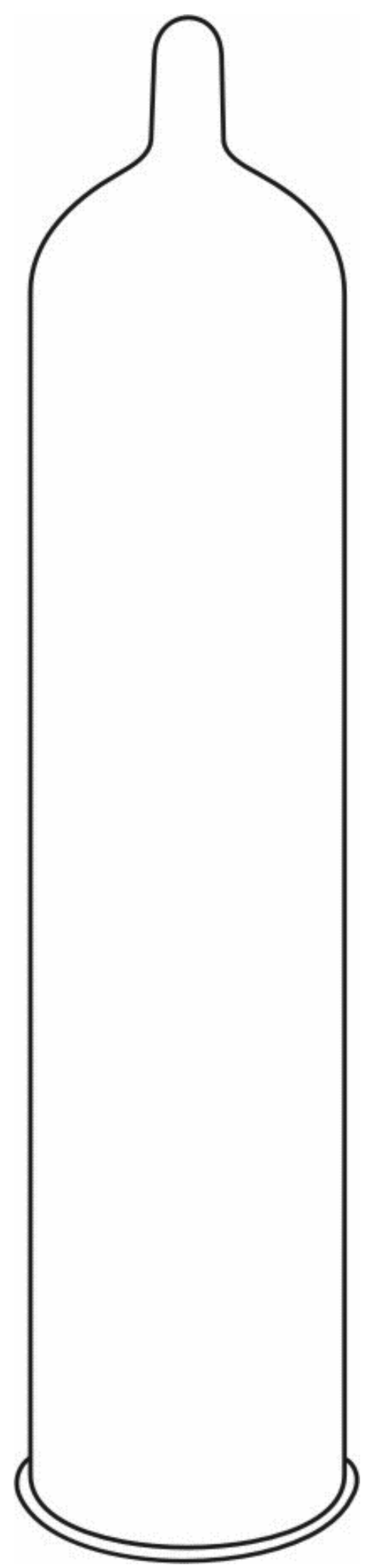


APÊNDICE B - DESENHOS ESQUEMÁTICOS UTILIZADOS NA COLETA DE DADOS

b-) Camisinha com formato anatômico e textura lisa.

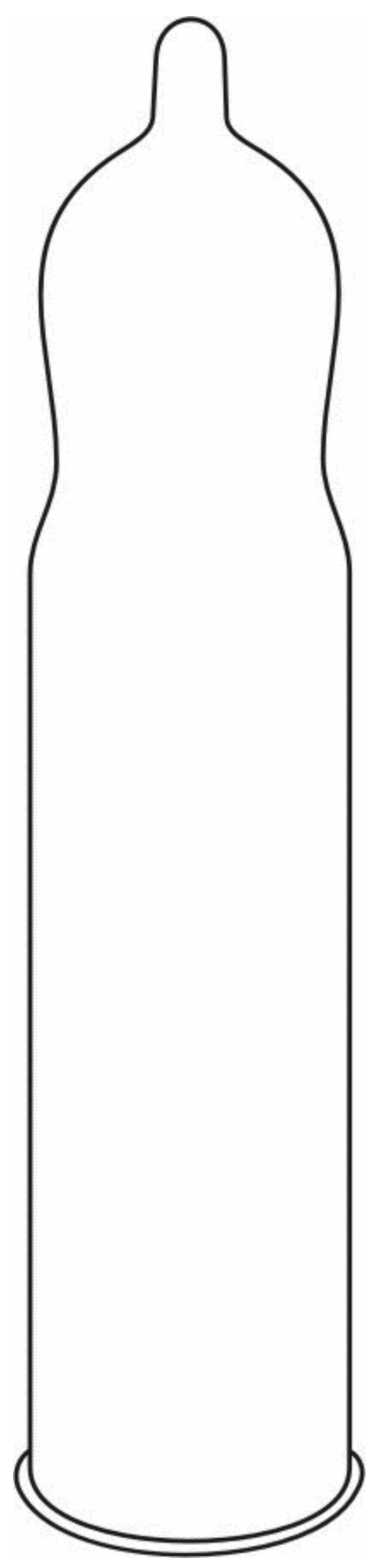


APÊNDICE B - DESENHOS ESQUEMÁTICOS UTILIZADOS NA COLETA DE DADOS

c-) Camisinha com textura não lisa

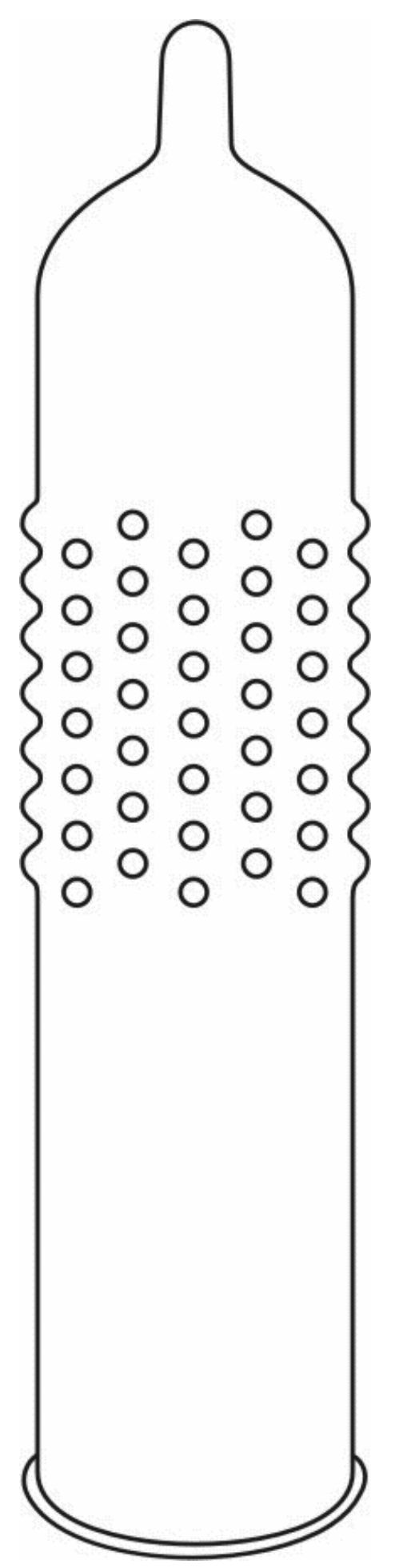




$$
\bar{\theta}
$$




$$
\bar{\theta}
$$




\section{APÊNDICE C - ESTRUTURA DO DATA FILE}

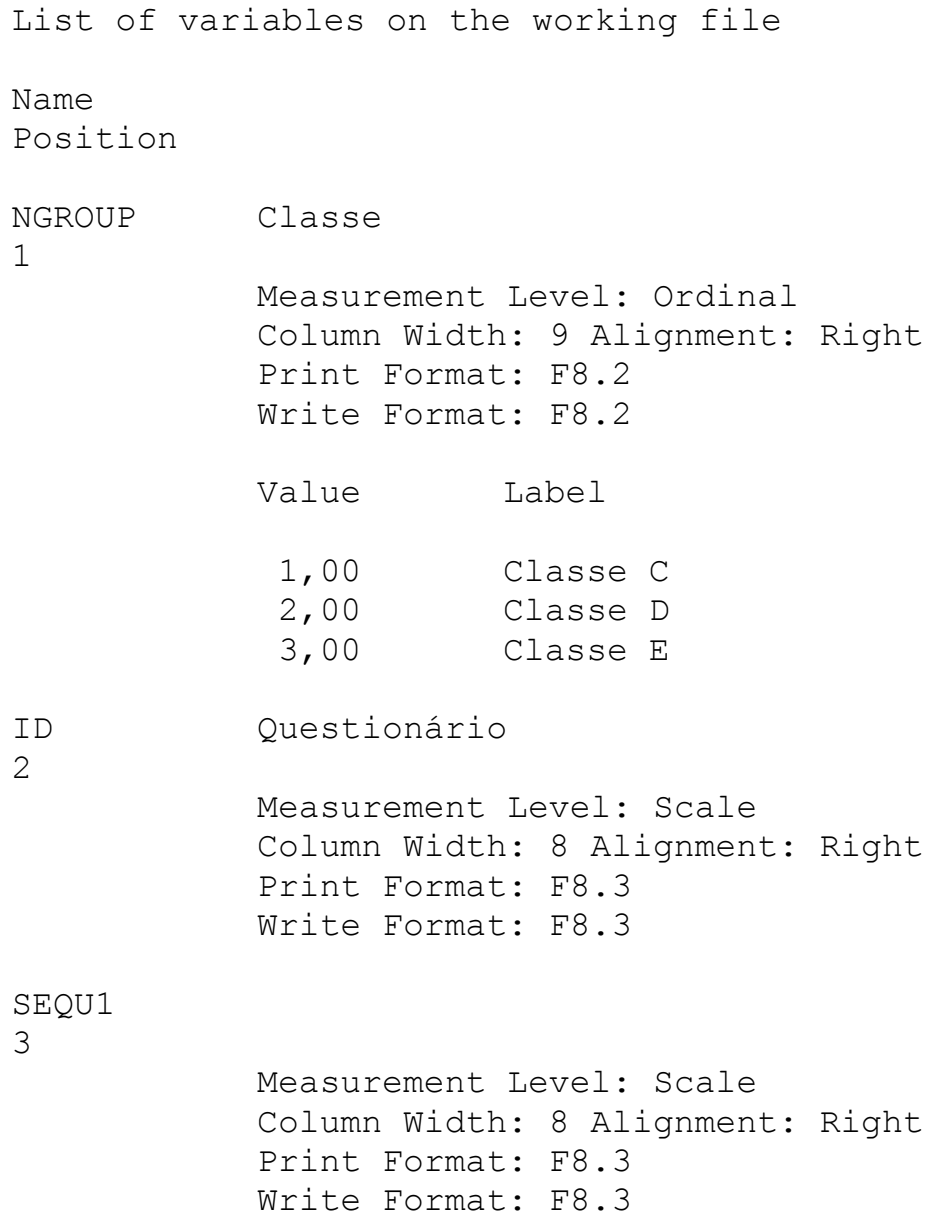

3

Measurement Level: Scale

Column Width: 8 Alignment: Right Print Format: F8.3

Write Format: F8.3

SEQU2

4

Measurement Level: Scale

Column Width: 8 Alignment: Right Print Format: $\mathrm{F} 8.3$

Write Format: F8.3

SEQU3

5

Measurement Level: Scale

Column Width: 8 Alignment: Right Print Format: $\mathrm{F} 8.3$

Write Format: F8.3

SEQU4

6

Measurement Level: Scale

Column Width: 8 Alignment: Right Print Format: F8.3

Write Format: F8.3 
Measurement Level: Scale

Column Width: 8 Alignment: Right

Print Format: F8.3

SEQU 6

Write Format: F8.3

8

Measurement Level: Scale

Column Width: 8 Alignment: Right

Print Format: F8.3

Write Format: F8.3

SEQU7

9

Measurement Level: Scale

Column Width: 8 Alignment: Right

Print Format: F8.3

Write Format: F8.3

SEQU8

10

Measurement Level: Scale

Column Width: 8 Alignment: Right

Print Format: F8.3

Write Format: F8.3

SEQU9

11

Measurement Level: Scale

Column Width: 8 Alignment: Right Print Format: F8.3

Write Format: F8.3

SEQU10

12

Measurement Level: Scale

Column Width: 8 Alignment: Right Print Format: F8.3

Write Format: F8.3

SEQU11

13

Measurement Level: Scale

Column Width: 8 Alignment: Right

Print Format: F8.3

Write Format: F8.3

SEQU12

14

Measurement Level: Scale

Column Width: 8 Alignment: Right

Print Format: F8.3

Write Format: F8.3 
SEQU13

15

Measurement Level: Scale

Column Width: 8 Alignment: Right

Print Format: $\mathrm{F} 8.3$

Write Format: F8.3

SEQU14

16

Measurement Level: Scale

Column Width: 8 Alignment: Right Print Format: F8.3

Write Format: F8.3

SEQU15

17

Measurement Level: Scale

Column Width: 8 Alignment: Right Print Format: F8.3

Write Format: F8.3

SEQU16

18

Measurement Level: Scale

Column Width: 8 Alignment: Right Print Format: F8.3

Write Format: F8.3

SEQU17

19

Measurement Level: Scale

Column Width: 8 Alignment: Right Print Format: $F 8.3$

Write Format: F8.3

SEQU18

20

Measurement Level: Scale

Column Width: 8 Alignment: Right

Print Format: F8.3

Write Format: F8.3

SEQU19

21

Measurement Level: Scale

Column Width: 8 Alignment: Right

Print Format: F8.3

Write Format: F8.3

SEQU20

22

Measurement Level: Scale

Column Width: 8 Alignment: Right

Print Format: F8.3

Write Format: F8.3 
I DADE

23

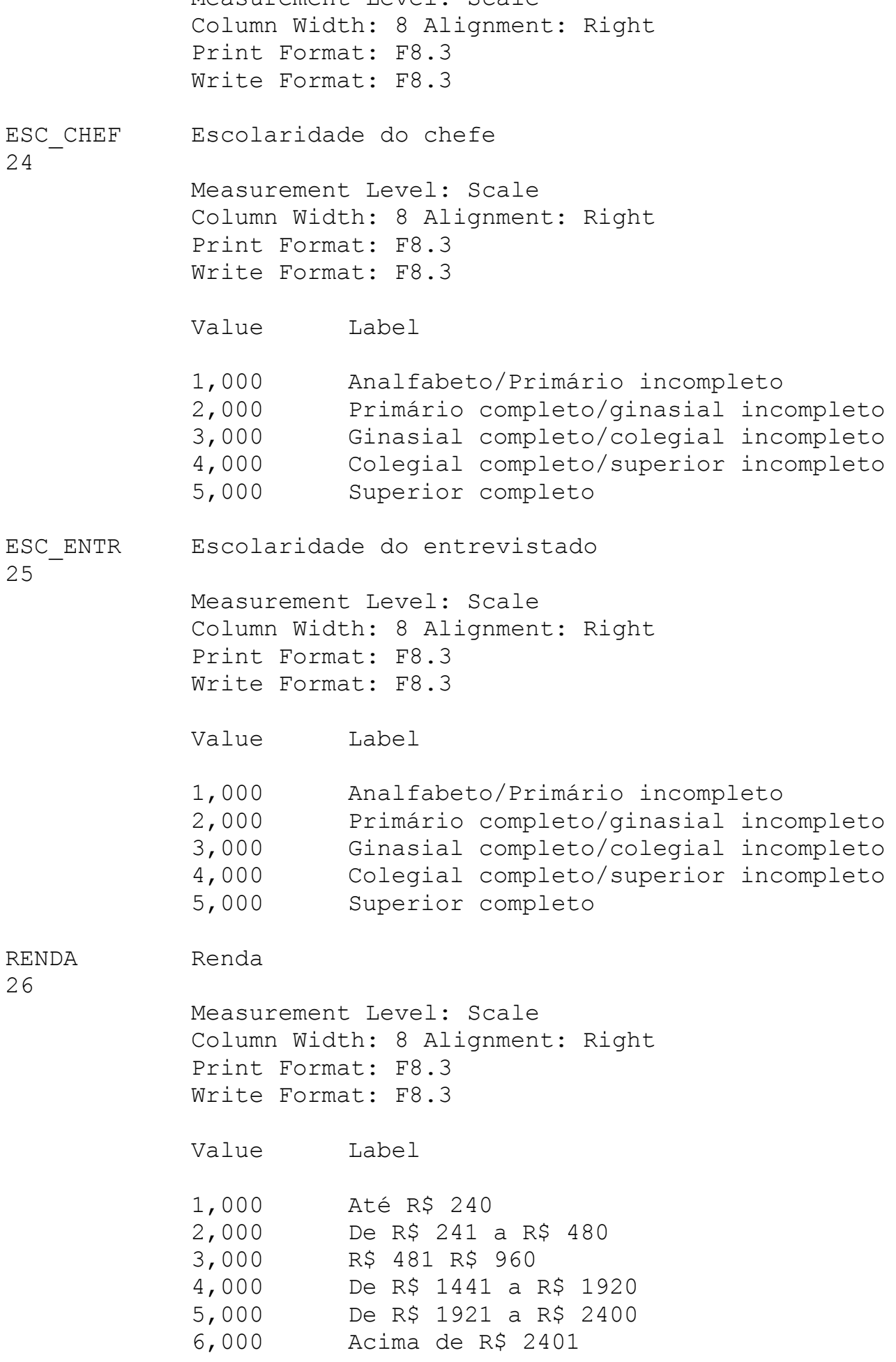

Idade

Measurement Level: Scale

Column Width: 8 Alignment: Right

rint Format: $F 8.3$

Measurement Level: Scale

: $F 8.3$

Value Label

1,000 Analfabeto/Primário incompleto

3,000 Ginasial completo/colegial incompleto

, $000 \quad$ Colegial completo/superior incompleto

Measurement Level: Scale

Value Label

1,000 Analfabeto/Primário incompleto

2,000 Primário completo/ginasial incompleto

Ginasial completo/colegial incompleto

4,000 Colegial completo/superior incompleto 


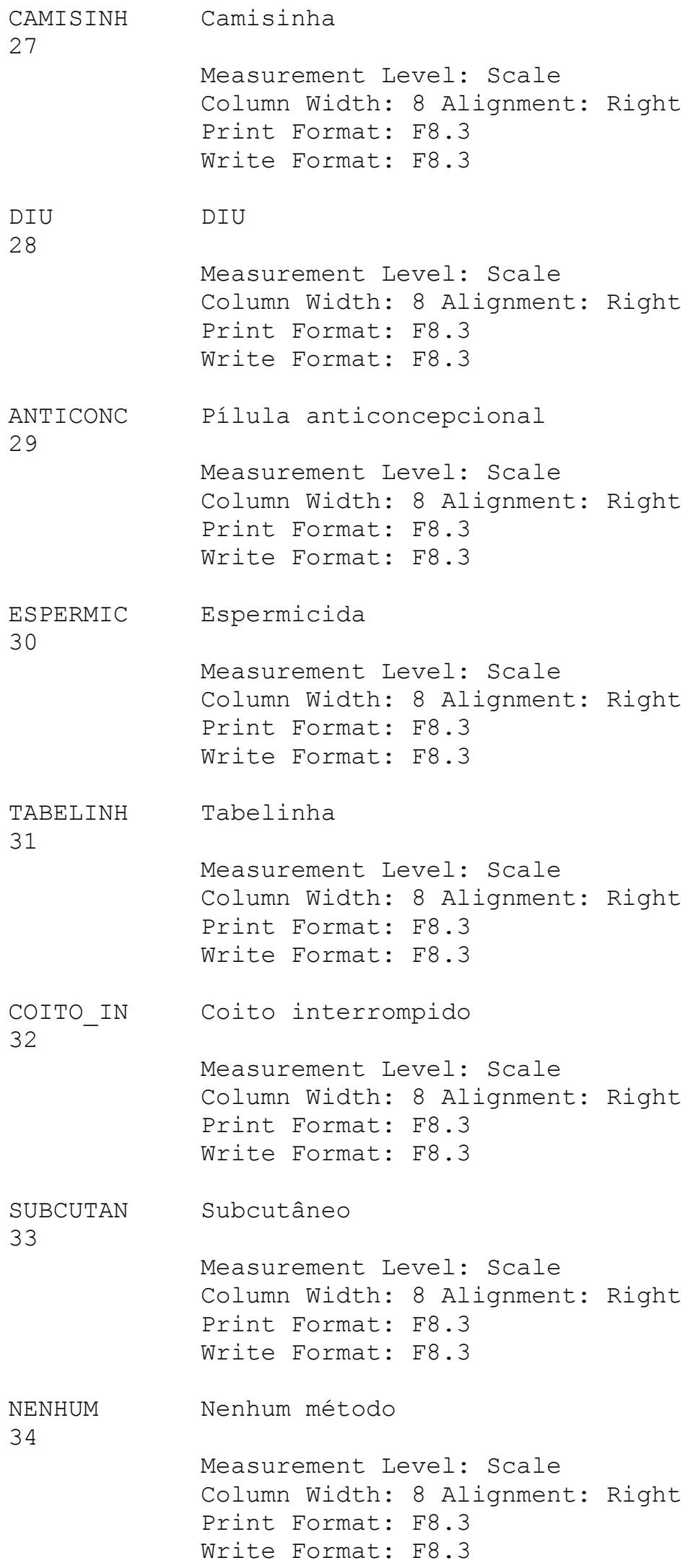




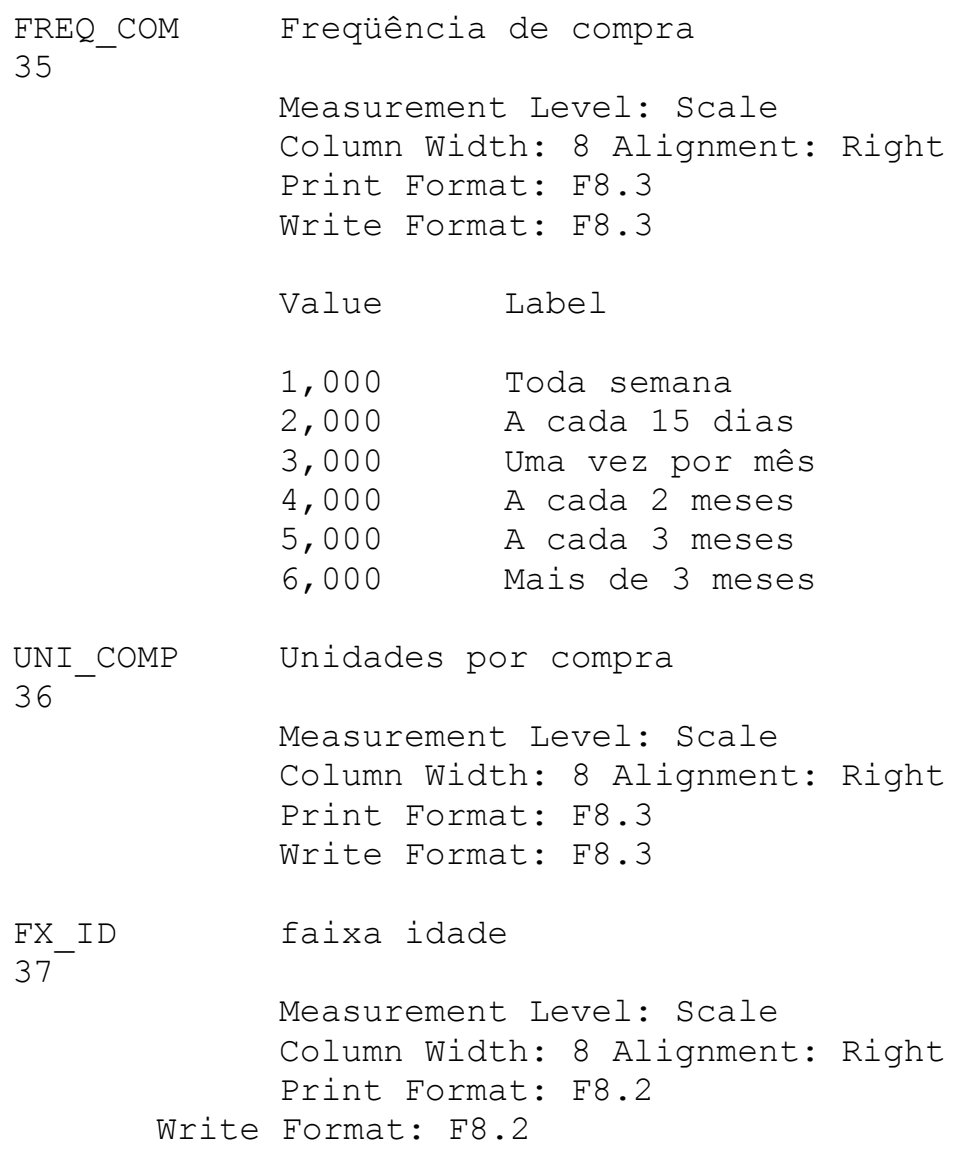




\section{APÊNDICE D - SINTAXE DO PROGRAMA}

Sintaxe do Programa - Agrupamento por classe econômica

CONJOINT PLAN 'a:Inovo_preserv.sav'

IDATA*

ISEQUENCE = sequ1 to sequ20

ISUBJECT=ngroup

IFACTORS marca (discrete) conforto (discrete) preço (discrete) espessur (discrete) textura (discrete)/PLOT ALL.

Sintaxe do Programa - Agrupamento por faixa de idade

CONJOINT PLAN 'a:Inovo_preserv.sav'

IDATA*

ISEQUENCE $=$ sequ 1 to sequ20

ISUBJECT=fx_id

/FACTORS marca (discrete) conforto (discrete) preço (discrete) espessur (discrete) textura (discrete)/PLOT ALL. 


\section{ANEXO}

ANEXO A - DETALHES DO CRITÉRIO DE CLASSIFICAÇÃO ECONÔMICA BRASIL

\section{SISTEMA DE PONTOS}

Posse de itens

\begin{tabular}{|l|c|c|c|c|c|}
\hline \multirow{2}{*}{ Televisão em cores } & $\begin{array}{c}\text { Não } \\
\text { tem }\end{array}$ & \multicolumn{5}{|c|}{ T E M } \\
\cline { 2 - 6 } & 0 & 1 & 2 & 3 & 4 ou + \\
\cline { 2 - 6 } Rádio & 0 & 2 & 3 & 4 & 5 \\
Banheiro & 0 & 2 & 3 & 4 & 4 \\
Automóvel & 0 & 2 & 4 & 5 & 5 \\
Empregada mensalista & 0 & 2 & 4 & 4 & 4 \\
Aspirador de pó & 0 & 1 & 1 & 1 & 1 \\
Máquina de lavar & 0 & 1 & 1 & 1 & 1 \\
Videocassete e/ou DVD & 0 & 2 & 2 & 2 & 2 \\
Geladeira & 0 & 2 & 2 & 2 & 2 \\
Freezer (aparelho independente & 0 & 1 & 1 & 1 & 1 \\
ou parte da geladeira duplex) & & & & & \\
\hline \hline
\end{tabular}

Grau de Instruçäo do chefe de família

\begin{tabular}{|l|l|}
\hline Analfabeto / Primário incompleto & 0 \\
Primário completo / Ginasial incompleto & 1 \\
Ginasial completo / Colegial incompleto & 2 \\
Colegial completo / Superior incompleto & 3 \\
\hline Superior completo & 5 \\
\hline
\end{tabular}

\section{CORTES DO CRITÉRIO BRASIL}

\begin{tabular}{|c|c|c|}
\hline Classe & PONTOS & TOTAL BRASIL (\%) \\
\hline A1 & $30-34$ & 1 \\
A2 & $25-29$ & 5 \\
\hline B1 & $21-24$ & 9 \\
B2 & $17-20$ & 14 \\
C & $11-16$ & 36 \\
D & $6-10$ & 31 \\
E & $0-5$ & 4 \\
\hline
\end{tabular}




\section{PROCEDIMENTO NA COLETA DOS ITENS}

É importante e necessário que o critério seja aplicado de forma uniforme e precisa. Para tanto, é fundamental atender integralmente as definições e procedimentos citados a seguir.

Para aparelhos domésticos em geral devemos:

\section{Considerar os seguintes casos}

Bem alugado em caráter permanente

Bem emprestado de outro domicilio há mais de 6 meses

Bem quebrado há menos de 6 meses

\section{Não considerar os seguintes casos}

Bem emprestado para outro domicilio há mais de 6 meses

Bem quebrado há mais de 6 meses

Bem alugado em caráter eventual

Bem de propriedade de empregados ou pensionistas

\section{$\underline{\text { Televisores }}$}

Considerar apenas os televisores em cores. Televisores de uso de empregados domésticos (declaração espontânea) só devem ser considerados caso tenha(m) sido adquirido(s) pela familia empregadora.

\section{Rádio}

Considerar qualquer tipo de rádio no domicílio, mesmo que esteja incorporado a outro equipamento de som ou televisor. Rádios tipo walkman, conjunto $3 \mathrm{em} 1$ ou microsystems devem ser considerados, desde que possam sintonizar as emissoras de rádio convencionais. Não pode ser considerado o rádio de automóvel.

\section{Banheiro}

O que define o banheiro é a existência de vaso sanitário. Considerar todos os banheiros e lavabos com vaso sanitário, incluindo os de empregada, os localizados fora de casa e os da(s) suite(s). Para ser considerado, o banheiro tem que ser privativo do domicilio. Banheiros coletivos (que servem a mais de uma habitação)não devem ser considerados.

\section{Automóvel}

Não considerar táxis, vans ou pick-ups usados para fretes, ou qualquer veículo usado para atividades profissionais. Veículos de uso misto (lazer e profissional) não devem ser considerados. 


\section{Empregada doméstica}

Considerar apenas os empregados mensalistas, isto é, aqueles que trabalham pelo menos 5 dias por semana, durmam ou não no emprego. Não esquecer de incluir babás, motoristas, cozinheiras, copeiras, arrumadeiras, considerando sempre os mensalistas.

\section{Aspirador de Pó}

Considerar mesmo que seja portátil e também máquina de limpar a vapor (Vaporetto).

\section{Máquina de Lavar}

Perguntar sobre máquina de lavar roupa, mas quando mencionado espontaneamente o tanquinho deve ser considerado.

\section{Videocassete e/ou DVD}

Verificar presença de qualquer tipo de vídeo cassete ou aparelho de DVD.

\section{Geladeira e Freezer}

No quadro de pontuação há duas linhas independentes para assinalar a posse de geladeira e freezer respectivamente. A pontuação entretanto, não é totalmente independente, pois uma geladeira duplex (de duas portas), vale tantos pontos quanto uma geladeira simples (uma porta) mais um freezer.

As possibilidades são:

\begin{tabular}{l|l|}
\hline Não possui geladeira nem freezer & 0 ponto \\
\hline Possui geladeira simples (não duplex) e não possui freezer & 2 pontos \\
\hline Possui geladeira de duas portas e não possui freezer & 3 pontos \\
\hline Possui geladeira de duas portas e freezer & 3 pontos \\
\hline Possui freezer mas não geladeira (caso raro mas aceitável) & 1 ponto \\
\hline
\end{tabular}

